\title{
A Framework for Integrated Sustainability Assessment to support decision making. Application to solar thermal and natural gas combined cycle electricity production in Mexico
}

TESIS DOCTORAL

Irene Rodríguez Serrano Licenciada en Ciencias Ambientales

Universidad de Alcalá de Henares

\author{
DIRECTORES \\ Natalia Caldés Gómez Dra. Economía \\ Centro de Investigaciones Energéticas, Medioambientales y Tecnológicas
}

Alberto Garrido Colmenero Dr. Ingeniero Agrónomo

Universidad Politécnica de Madrid

Madrid 2017 
Algunas personas quieren que suceda, otras esperan que suceda, otras hacen que suceda

A mis padres, abuela, hermano y familia 


\section{Agradecimientos}

Con esta sección pretendo reflejar, en unos pocos párrafos, mi enorme agradecimiento a todas aquellas personas que han contribuido, de un modo y otro, a realizar este objetivo.

En primer lugar, quería agradecer una vez más (ya he perdido ya la cuenta) a mi directora de tesis, la Dra. Natalia Caldés. El porqué es más complicado de expresar, digamos que, básicamente, por todo. Empezando por el infinito aprendizaje a su lado, esta tesis ha sido un largo recorrido en el que puedo decir que no he estado sola en ningún momento. Sus aportaciones técnicas y empujones en momentos críticos han sido imprescindibles. Muchísimas correcciones y tiempo robado en los cuales la paciencia y empatía siempre han estado presentes, además de otras muchas bondades personales. $\mathrm{He}$ tenido una suerte inmensa por tenerte de directora y mucho más como amiga, gracias por toda tu ayuda y gracias por creer en mí desde el primer momento. También agradecer a mi director Dr. Alberto Garrido por su apoyo y correcciones que han ayudado a mejorar la tesis. Como no agradecer a toda la Unidad de Análisis de Sistemas Energéticos de Ciemat. Empezando por Yolanda y Cristina, muchas gracias por dejarme aprender tanto, por las largas discusiones y enriquecedoras modificaciones, y también por vuestra paciencia y el buen trato personal. También agradecer al resto de la unidad por los comentarios de mejora en las presentaciones y los infinitos buenos momentos con Israel, Carmen, Ana, Dani, Helena, Andrés y todas las personas que en algún momento estuvieron en la unidad: Diego, Rosa, Marta, Pilar, etc. Por último, especial agradecimiento a Eric, por su disposición a ayudarme siempre con pequeñas grandes cosas, y por la paciencia; y a Marylin, mi compañera batalla, con la que he recorrido todo este proceso y hemos compartido juntas todas las sensaciones de esta etapa.

No me puedo olvidar de algunas personas que han sido elementos clave para esta tesis. Agradecimientos a la PSA, a Almudena Bailador y a Rafael Pérez por la ayuda en los casos de estudio. Gracias a Christian Oltra y Roser Sala por el aprendizaje y estancia en el CISOT. Especial agradecimiento al Dr. Luis Crespo, quien me ha enseñado tanto sobre la tecnología solar y me ha ayudado a otorgar al trabajo una calidad técnica, además de los buenos momentos. Asimismo, muchas gracias al Dr. Antonio Rodríguez por toda la ayuda en los temas relacionados con México, además del cariño recibido.

I also would like to thank some of the experts I had the opportunity to meet, attend their classes and discuss with in UC Berkeley: Dr. Alasdain Cohen, Dr. Daniel Kammen, Dr. David Dornfeld, Dr. Nicholas Sakellariou and Dr. Steven Weissman. 
En un ámbito más personal, quiero agradecer a mis padres, imprescindibles en cada momento de mi vida y por supuesto especialmente en éste, los que me han dado la oportunidad de formarme y poder realizar este trabajo. Los que me han ayudado en los buenos y en los malos momentos y los que me han apoyado por encima de todo. Soy muy afortunada por teneros a mi lado y espero que estas cortas frases reflejen todo lo que suponéis para mí. Este sentimiento se expande hacia toda mi familia, a mi hermano, que siempre ha estado presente, y aunque más en la distancia en estos últimos años, me ha seguido mostrando su apoyo; a mis tías, a las que quiero muchísimo; a mis tíos políticos y primo, siempre dispuestos a ayudarme; y a las que dan la alegría a la familia, Raquel y Alba, y a la pequeña que está por llegar. Por último, darle las gracias infinitas a mi abuela, por todo lo que ha hecho y sigue haciendo por mí, eres imprescindible.

También quiero mencionar a aquellas personas que te hacen llenarte de aire y energía para poder continuar el trabajo: mis amigas de toda la vida, gracias a cada una de vosotras por todos los viajes, reuniones, salidas y momentos divertidos, y también los no tan divertidos, gracias por todos estos años y los que nos quedan: Ale, Irene, Yenai, Teresa, Soraya, Elena y Nerea. Como no agradecer a Mairana, tantísimos momentos divertidos, debates sobre temas profundos, viajes y como no, interminables visitas al teatro Lara, gracias por el oxígeno que me dais para continuar. También agradecer a Portillo, por toda la amistad y muchos momentos imborrables como la visita de SF, y al resto del grupo por todos los buenos momentos y viajes: Marcos, Nuria, Raúl y Pablo. También agradecer a Sergio, que aunque últimamente estamos más distanciados, sé que todos los años vividos siguen presentes de algún modo.

Especial cariño a los que conocí en esta etapa: todo lo vivido con Ángela, a la que tengo un cariño inmenso y que sin ella mi estancia no hubiera sido lo mismo. Y especial cariño a la persona que más lejos está pero a la vez tan cerca, gracias Joaquín por los geniales momentos en tu querido Madrid y por mantener la amistad todos estos años, por tantos audios a distancia y todo el apoyo que siempre me das. Finalmente, gracias a la gente de verano azul, por el cariño que recibo cuando les veo, y en general gracias a todas las personas que fueron importantes en algún momento de mi vida. De un modo más abstracto, también quería agradecer a esos seres que me hacen simplificar los problemas y la vida, la ayuda aportada en las protectoras es recíproca y gracias a las personas que me permiten colaborar; gracias por todo lo vivido, Tobías y Dana. 


\section{Summary}

Decision makers interested in promoting sustainable development must equally consider the environmental, economic and social effects of any project initiative. Moreover, in an increasingly global world, these effects should be accounted for over the whole value chain, as many of involved economic activities may occur in different countries whose contexts and regulations differ substantially. In order to support decision makers in achieving this goal, this thesis proposes the "Framework for Integrated Sustainability Assessment" (FISA) as a methodological framework to conduct a comprehensive sustainability impact assessment of the production of goods and services along their supply chain. The different chapters of this thesis contain a detailed description of the FISA framework as well as its application to two electricity generation alternatives in Mexico to test the validity and usefulness of the proposed framework.

One of the added values of FISA is that it accounts for the total effects of any product or service along its value chain across the three sustainability pillars. First, thanks to the Multiregional scope of the Input Output methodology (Multiregional Input Output "MRIO") and the use of the World Input Output Database (WIOD), it is possible to assess the direct, indirect and induced socioeconomic and environmental effects derived from the increase in the demand of goods and services across the different economic sectors and countries involved in the supply chain. Second, the integration of the social dimension is achieved by combining the MRIO results with information on different social risks existing in the same WIOD economic sectors worldwide included in the Social Hotspots Database (SHDB). Such combination results in the Project Social Index (PSI), which helps identify the potential harmful Project Social Hotspots (PSH), defined as those economic sectors that result largely stimulated by the project (in terms of working hours) and also which present high social risks.

Finally, the three types of impacts are simultaneously reported by means of FISA charts, making it possible to identify the larger positive but also negative impacts of any project within the three sustainability pillars across those countries involved directly and indirectly in its supply chain. Furthermore, this methodological framework can be also used to compare the sustainability performance of alternative investment choices and guide decision makers towards the selection of the best option from a comprehensive sustainability point of view. 
FISA's theoretical and methodological basis, together with its application to concrete case studies, are presented in four different chapters. First chapter describes in detail the proposed methodological framework. Next, FISA is applied to conduct a sustainability impact assessment of the supply chain of Solar Thermal Electricity (STE) generation in Mexico. The estimation of the associated economic, environmental and social impacts along the STE supply chain makes it possible to identify the sustainability hotspots both from direct and indirect effects, while considering the international trade within the different project phases. Results show that the largest socioeconomic effects occur in Mexico mainly as a result of direct effects during the investment phase. With regards to labor impacts, while most of the employment effects (both in terms of job creation and working hours) take place in Mexico, the largest income generation figures occur outside Mexico due to indirect effects. As for the social dimension, results indicate that social risks from direct effects identified by the Project Social Hotspots in Mexico should be monitored. Regarding environmental effects, most of the impacts would take place beyond Mexican borders, mainly as a result of indirect activities during the investment phase. The results from this assessment could help decisions makers identify not only direct sustainability hotspots of the Solar Thermal Electricity project but also the indirect ones occurred throughout the supply chain. These results could also guide decision makers towards implementing the required actions and measures to overcome the potential negative impacts and foster the positive ones.

The second FISA's case study application presented in Chapter 3 consists on the comparison of the sustainability assessment results associated to the STE with those obtained from electricity produced with Natural Gas Combined Cycle (NGCC) technology. Socioeconomic results show that STE would create a higher added value and jobs of better quality. With regards to the social dimension, effects from both technologies involve some social risks but they are easier to identify in the case of STE from direct effects. As for the environmental effects, NGCC's impacts are remarkably larger than STE's ones, mainly as a result of natural gas consumption. Regarding the location of the effects, despite its embedded international trade, most impacts would take place in Mexico, especially those associated to the NGCC technology. Again, the results derived from the application of FISA to these alternative case studies could help decision makers in the selection of the most sustainable energy investment choice and 
guide them towards applying the necessary measures to minimize the negative impacts of the selected project on the social, economic and environmental sustainability pillars while promoting the positive ones.

Finally, in order to test the relevance and usefulness of the FISA framework for decision makers as well as the impact of their preferences on the FISA's results, an evaluation has been conducted by means of a questionnaire to Mexican decision makers involved in the energy sector. This survey intended, first, to facilitate the interpretation of the FISA results, which have been classified into different sustainability indicators categorized into socio-economic, social and environmental dimensions, and later, transformed and consolidated into a single "Aggregated Sustainability Endpoints" (ASE points) as a way to ease the decision making process. Second, the relevance of the FISA's results was analyzed in the survey to identify which impacts are considered a priority for decision makers. Next, the original FISA results were weighted according to the stakeholders' revealed preference over the various sustainability indicators. The obtained new weighted results allow to compare the two alternative technologies when considering the stakeholders preferences. Such comparison shows that, while the original results indicate that NGCC has an aggregated score 1.94 times worse than STE, when incorporating decision makers' priorities the ratio increases to 2.06. In this sense, the negative score of NGCC increased due to the relevance given by decision makers to environmental impacts where this technology achieves the largest negative figures, as well as some social risks like human rights risks. Furthermore, most of the interviewees considered FISA impacts useful for the decision making process, but recommended that the inclusion of other indicators such as the grid connection feasibility or the need for local components and personnel should be also considered.

This thesis concludes that the FISA framework could be a useful instrument for decision makers to analyze the impacts of alternative investment projects on the three sustainability dimensions. The results from the FISA applications to concrete case studies also suggest that, not only the direct but also the indirect effects occurring along the supply chain globally should be equally accounted across in the three sustainability dimensions. Additionally, the results indicate that when substituting electricity produced with NGCC by STE in Mexico, remarkable environmental benefits would take place and also larger socioeconomic benefits in terms of added value creation and quality of employments. Furthermore, the identified Project Social Hotspots indicate that some 
associated social risks should be monitored carefully, and they would be easier to identify in the case of STE technology from direct activities. Finally, following the results from the stakeholders' consultation, it can be concluded that the proposed tool is useful and informative for their decision making processes. 


\section{Resumen}

Los tomadores de decisiones de cualquier iniciativa cuya intención es fomentar el desarrollo sostenible deben tener igualmente en cuenta los efectos socioeconómicos, ambientales y los sociales. Además, dada la creciente globalización, estos efectos deben de ser tenidos en cuenta a lo largo de toda la cadena de valor. Esto es debido a que muchas de las actividades económicas involucradas pueden tener lugar en diferentes países con contextos y regulaciones sustancialmente diferentes. Para lograr este objetivo, esta tesis propone un marco para el análisis integrado de la sostenibilidad denominado FISA, por sus siglas en ingles "Framework for Integrated Sustainability Assessment". El objetivo de FISA es acometer un análisis de la sostenibilidad teniendo en cuenta los impactos ambientales, socio-económicos y sociales asociados a la producción de bienes y servicios a lo largo de su cadena de valor. Los diferentes capítulos de estas tesis incluyen una detallada descripción del marco FISA así como su aplicación a diferentes alternativas de generación eléctrica en México. Estas aplicaciones sirven para contrastar la validez y utilidad del marco propuesto.

Uno de los valores añadidos del marco FISA es que tiene en cuenta los efectos totales de cualquier producto o servicio a lo largo de su cadena de suministro en los tres pilares de la sostenibilidad. En primer lugar, gracias al enfoque multirregional de la metodología Input Output (Multiregional Input Output "MRIO") y el uso de la base de datos mundial WIOD (por sus siglas en inglés "World Input Output Database"), es posible analizar los efectos socioeconómicos y ambientales directos, indirectos e inducidos derivados de un aumento en la demanda de bienes y servicios en los diferentes sectores económicos y países involucrados en la cadena de valor. En segundo lugar, la dimensión social se integra en FISA mediante la combinación de los resultados del análisis MRIO con información de riesgos sociales incluidos en la base de datos "SHDB" (por sus siglas en inglés "Social Hotspot Database") adaptados a los sectores económicos de la WIOD. Esta combinación tiene como resultado la creación del "Índice Social del Proyecto" o PSI (por sus siglas en inglés "Project Social Index"). Este índice permite identificar los puntos sociales críticos del proyecto, o también llamados PSH (por sus siglas en inglés "Project Social Hotspots"). Los PSH corresponden a aquellos sectores económicos que resultan más estimulados por el proyecto (en términos de horas de trabajo) pero también los que albergan altos riesgos sociales. 
Finalmente, a través de los gráficos FISA, se puede identificar los mayores impactos positivos y negativos de cualquier proyecto en los tres pilares de la sostenibilidad. Estos gráficos también permiten distinguir en qué países acontecen dichos efectos tanto directa como indirectamente en su cadena de valor. Asimismo, este marco metodológico puede ser aplicado para comparar los impactos asociados a distintas alternativas de inversión y guiar a los tomadores de decisión hacia la opción más sostenible.

La base teórica y metodológica de FISA, junto con sus aplicaciones a casos de estudio concretos, se presentan en cuatro capítulos. El primer capítulo describe en detalle el marco metodológico propuesto. Seguidamente, el marco FISA es aplicado para realizar el análisis de los impactos en la sostenibilidad de la producción de electricidad en México a partir de energía solar térmica de concentración, también llamada STE (por sus siglas en inglés "Solar Thermal Electricity"). La estimación de los impactos económicos, ambientales y sociales a lo largo de su cadena de valor hace posible identificar los puntos críticos en la sostenibilidad tanto de efectos directos como de indirectos teniendo en cuenta el comercio internacional involucrado en las diferentes fases del proyecto. En lo referente a los impactos socio-económicos, los resultados muestran que los mayores impactos ocurren en México debido principalmente a los efectos directos durante la fase de inversión. En el caso de los impactos laborales, la mayor creación de empleo y horas de trabajo acontecen en México mientras que la mayor generación de ingresos por los salarios percibidos tiene lugar fuera de México a causa de efectos indirectos. En relación con la dimensión social, diferentes riesgos deben ser vigilados en México, especialmente aquellos identificados a causa de efectos directos y con especial énfasis en los identificados por los PSH. Los resultados de este análisis pueden ayudar a identificar no solo los puntos críticos en la sostenibilidad de la generación de electricidad a partir de energía solar térmica de concentración en México. Adicionalmente, también pueden ayudar a tomar medidas para minimizar los posibles impactos negativos y promover los positivos.

La segunda aplicación de FISA, presentada en el capítulo 3, consiste en la comparación de los resultados del análisis de la producción de electricidad con energía solar térmica STE con los resultados del análisis de electricidad generada con tecnología de ciclo combinado de gas natural o NGCC (por sus siglas en inglés "Natural Gas Combined Cycle”). Los resultados socioeconómicos muestran que la STE generaría una 
mayor creación de valor añadido y empleos de mejor calidad. En relación a la dimensión social, ambas tecnologías involucran ciertos riesgos sociales pero son más fáciles de identificar en el caso de la STE ya que son generados por los efectos directos. Asimismo, la tecnología de NGCC presenta impactos ambientales sustancialmente mayores, principalmente debido al consumo de gas natural. Nuevamente, los resultados de la comparación de las dos alternativas pueden ayudar a seleccionar la opción más sostenible.

Finalmente, para evaluar la relevancia y utilidad del marco FISA para los tomadores de decisiones así como para valorar sus preferencias sobre los impactos analizados en FISA, se ha elaborado un cuestionario para decisores en el campo de la energía en México. Como paso previo, para facilitar la interpretación, los resultados de FISA se agregan y consolidan en un único indicador llamado "ASE" (por sus siglas en inglés “Agregated Sustainability Endpoints"). En segundo lugar, se evalúa la relevancia de los distintos indicadores FISA a partir de las respuestas del cuestionario. Posteriormente, los resultados originales de FISA se modifican teniendo en cuenta los pesos de los diferentes indicadores de FISA por parte de los entrevistados. Los nuevos resultados permiten comparar la puntuación obtenida en las dos tecnologías. Esta comparación muestra que en los resultados originales de FISA, la producción de electricidad con tecnología de ciclo combinado de gas natural obtenía una puntuación 1,94 veces peor que la obtenida con energía solar de concentración. Posteriormente, cuando se tienen en cuenta las preferencias de los decisores, este ratio aumenta a 2,06. Este empeoramiento se debe a la gran relevancia que tienen los indicadores ambientales (donde el gas natural tiene impactos mucho más negativos) y algunos riesgos sociales para los tomadores de decisiones. Adicionalmente, una de las conclusiones de los entrevistados es que los impactos analizados por FISA resultan útiles en la toma de decisiones. Finalmente, los entrevistados también recomendaron la consideración de otros indicadores como son la conexión a red o el contenido local.

Esta tesis concluye que el marco FISA puede ser un instrumento útil para la toma de decisiones, en concreto, para analizar los impactos totales en los tres pilares de la sostenibilidad de cualquier proyecto de inversión a lo largo de su cadena de valor. Adicionalmente, los resultados de las aplicaciones de FISA sugieren que la sustitución de producción eléctrica con gas natural por energía solar de concentración conllevaría grandes beneficios ambientales y socioeconómicos en términos de creación de valor 
añadido y empleos de mayor calidad. Asimismo, los puntos críticos sociales del proyecto (PSH) identificados indican que existen algunos riesgos sociales que deberían ser monitorizados. Finalmente, según los encuestados, se puede concluir que el marco propuesto es útil e informativo para los procesos de toma de decisiones. 


\section{Table of Contents}

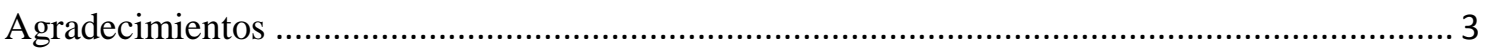

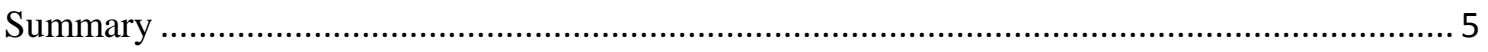

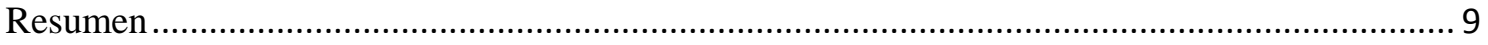

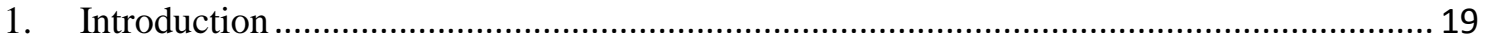

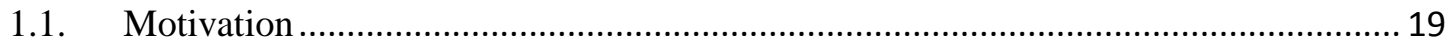

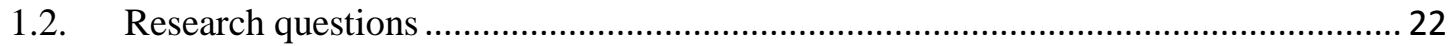

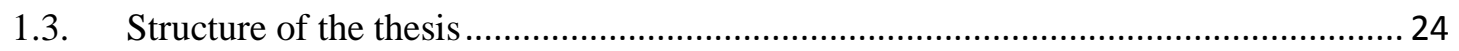

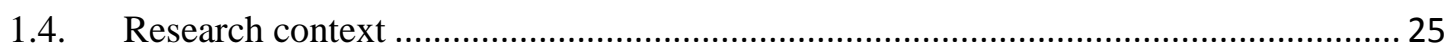

1.5. Statement on Publications involved in this thesis ..................................................... 27

2. Using the Framework for Integrated Sustainability Assessment (FISA) to expand the Multiregional Input-Output analysis to account for the three pillars of sustainability................ 29

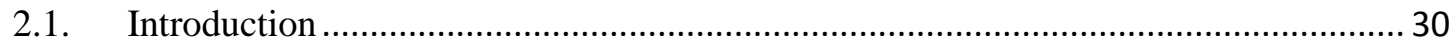

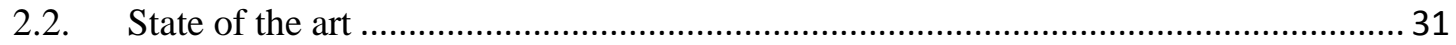

2.3. Methodological integration: Framework for Integrated Sustainability Assessment (FISA) 34

2.4. Conclusions

3. Assessing the three sustainability pillars through the Framework for Integrated

Sustainability Assessment (FISA): case study of a Solar Thermal Electricity project in Mexico 49

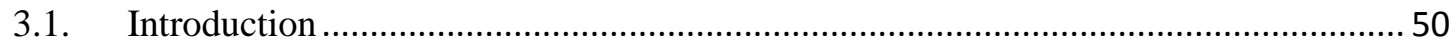

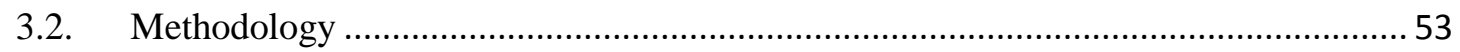

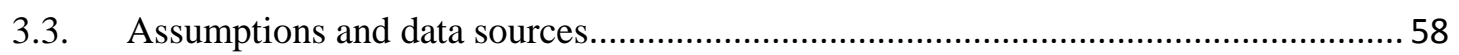

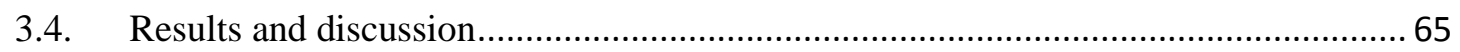

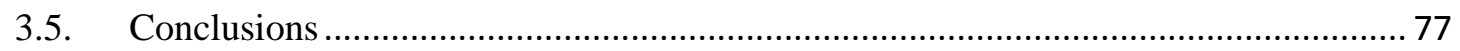

4. Sustainability impact assessment of alternative Solar Thermal Electricity and Natural Gas Combined Cycle electricity production in Mexico .................................................................... 79

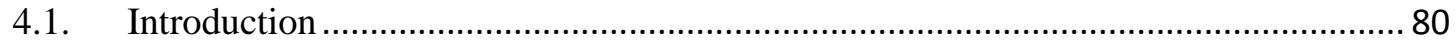

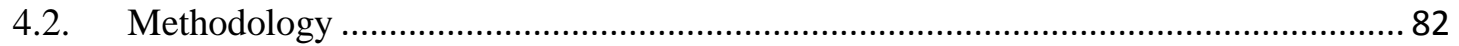

4.3. Application of FISA: impact assessment comparison of STE and NGCC for electricity

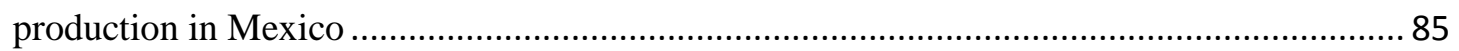

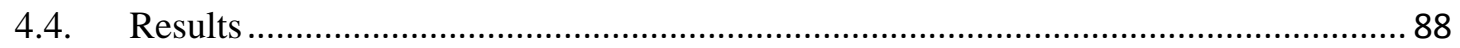

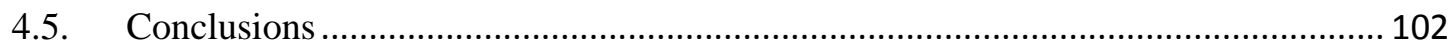

5. Comparing the Sustainability Impacts of Solar Thermal and Natural Gas Combined Cycle for Electricity Production in Mexico: Accounting for Decision Makers' Priorities .................. 104 


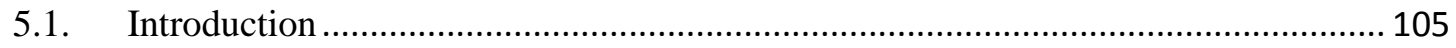

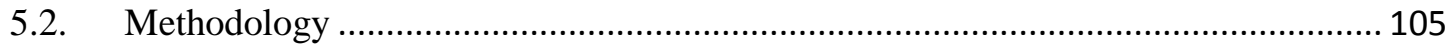

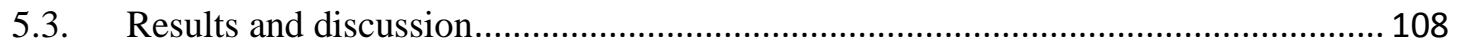

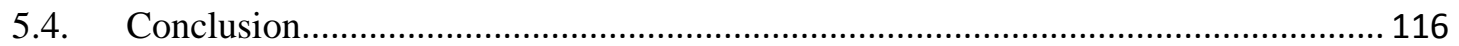

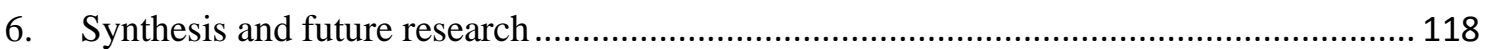

6.1. Main conclusions and research contributions ..................................................... 118

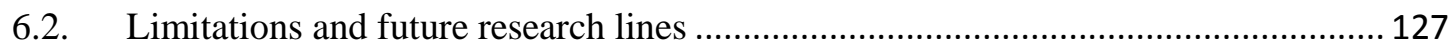

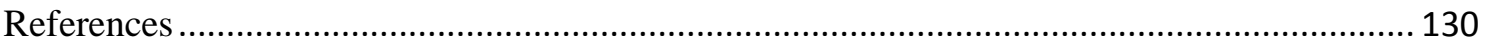

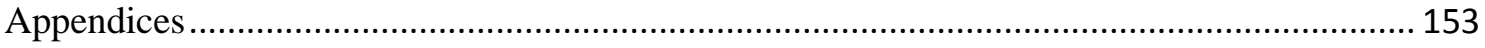

Appendix 3.1. Detailed investment costs shares breakdown of the STE case study............. 153

Appendix 3.2. Excluded social risk indicators in the analysis ........................................... 157

Appendix 4.1. Social themes and impact categories within the SHDB ............................... 159

Appendix 4.2. FISA framework and methodological steps ............................................... 160

Appendix 4.3. Investment cost for STE and NGCC and labor contribution ......................... 161

Appendix 4.4. Annual costs for STE and NGCC (without fuel and financial costs) ............ 162

Appendix 4.5. STE and NGCC investment and O\&M demand vectors .............................. 163

Appendix 4.6. Environmental impact categories and characterization factors used .............. 164

Appendix 4.7. Assumptions used for the calculation of induced effects by country of origin 164

Appendix 4.8. Direct and indirect effects of both technologies by social impact category .. 165

Appendix 4.9. Contribution of Project Social Hotspots of NGCC and STE......................... 165

Appendix 4.10. Total environmental results for both technologies and comparison with

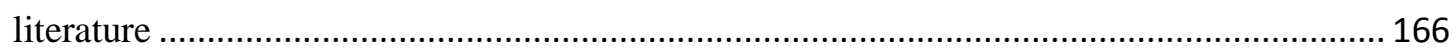

Appendix 4.11. Contribution of total effects of STE and NGCC ....................................... 166

Appendix 4.12. Summarized impact comparison of total effects between NGCC and STE

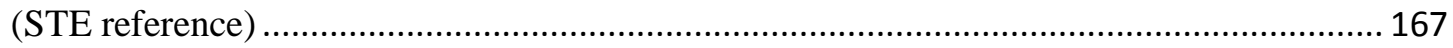

Appendix 5.1 Invitation and reminder email for the questionnaire case study ..................... 168

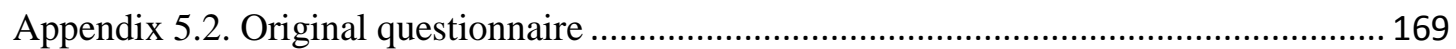

Appendix 5.3. Original description of suggested indicators (Linked online to Part 3 of the

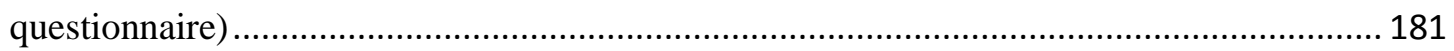

Appendix 5.4. Interviewees' detailed answers to optional questions of the survey ............... 183 


\section{List of Tables}

Table 2.1 Literature review of methodologies assessing one or more pillars listing barriers to a

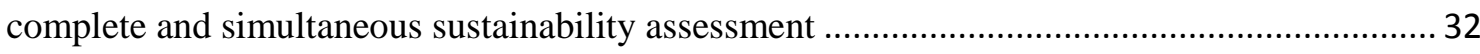

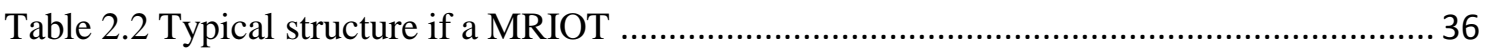

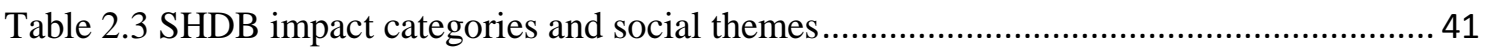

Table 3.1 Basic technical configuration of the studied STE plan ............................................. 59

Table 3.2 Investment and O\&M costs of the STE plant (in million US\$, "MUS\$") .................... 60

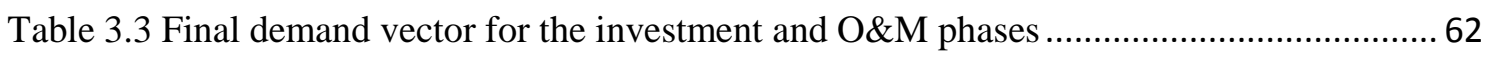

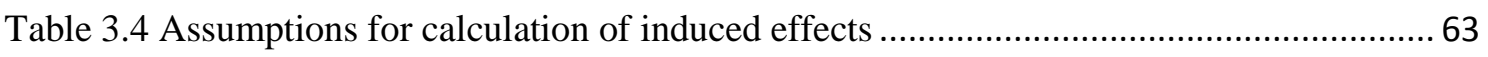

Table 3.5 Environmental impact categories assessed and characterization factors considered .. 64

Table 3.6 Direct, indirect and total socioeconomic effects and contribution of Mexico ............. 65

Table 3.7 Total socioeconomic impacts by project phases and contribution of Mexico.............. 67

Table 3.8 Direct, indirect and total social effects and contribution in Mexico ............................ 68

Table 3.9 Social effects by phases (PSI values) and contribution of Mexico ..............................69

Table 3.10 Social risks decomposition of the largest PSH "renting of machinery and other

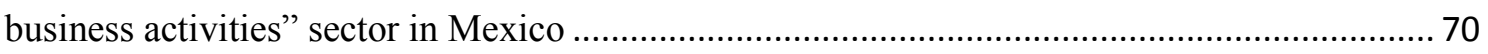

Table 3.11 Direct, indirect and total environmental effects per kWh inside and outside Mexico

Table 3.12 Total environmental impacts by project phases distinguishing national effects, and comparisons of impacts with literature

Table 4.1 Direct and indirect socioeconomic effects distinguishing national and international

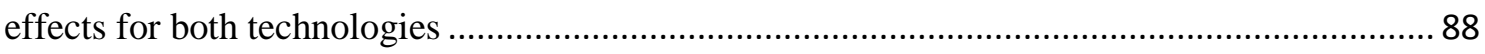

Table 4.2 National and international socioeconomic effects of the two project phases.............. 90

Table 4.3 Direct and indirect social effects differentiating national impacts in Mexico.............. 91

Table 4.4 Impacts in Mexico and outside Mexico in the investment and operation phases ....... 92

Table 4.5 Average risk value of the largest PSH in each social category and riskiest social issues

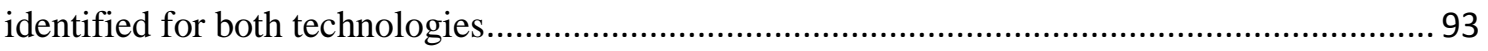

Table 4.6 Direct and indirect environmental effects in Mexico and outside Mexico ................. 95

Table 4.7 National and international environmental effects in the different project phases ....... 96

Table 5.1 FISA results for STE and NGCC in Mexico .......................................................... 109

Table 5.2 Reference FISA \% results, ASE points, averaged weighted points and averaged ranking points for STE and for socioeconomic impacts ....................................................... 110

Table 5.3 Social risks for FISA results (in \%), ASE points, and averaged weighted and ranking

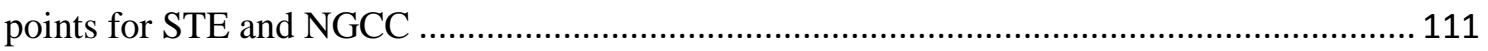

Table 5.4 Environmental impacts for FISA results, ASE points and averaged weighted and ranking points for STE and NGCC.... 


\section{List of Figures}

Figure 1.1 Structure of the thesis. Source: own elaboration.................................................... 25

Figure 2.1 Methodological integration through FISA. Source: Own elaboration ....................... 35

Figure 2.2 SHDB-MRIO linkage with WIOD countries and sectors. Source: Own elaboration 44

Figure 2.3 Combined impacts trough FISA chart. Source: Own elaboration ............................ 45

Figure 3.1 Social Hotspot Database five impact categories and social themes. Source: Own

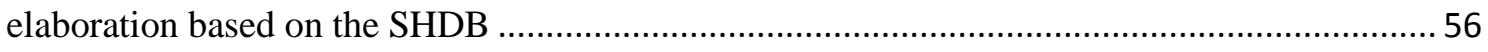

Figure 3.2 Steps of the proposed Framework for Integrated Sustainability Assessment (FISA).

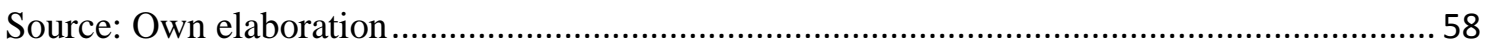

Figure 3.3 Top sectors contribution to socioeconomic impacts. Source: Own elaboration ......... 68

Figure 3.4 Project Social Hotspots (PSH). Source: Own elaboration ....................................... 70

Figure 3.5 Top sectors contribution to environmental impacts. Source: Own elaboration .......... 73

Figure 3.6 Number of threatened species in 2000 affected by the top five riskiest stimulated

sectors. Source: Own elaboration based on EORA .................................................................... 74

Figure 3.7 Proportion of direct and indirect effects of sustainability impacts occurring in Mexico

and outside Mexico. Source: Own elaboration ................................................................. 75

Figure 3.8 Proportion of national and international effects by phases of the project. Source: Own

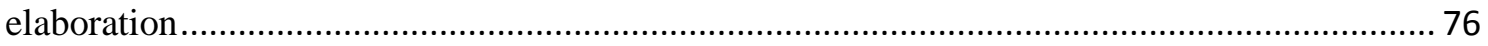

Figure 4.1 Contribution of sectors to socioeconomic impacts. Source: Own elaboration ........... 91

Figure 4.2 Contribution of sectors with highest PSI values to social dimension by impact

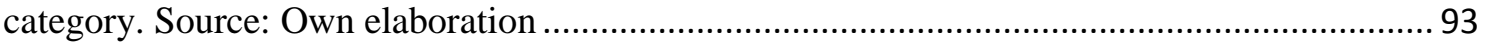

Figure 4.3 Contribution of economic sectors to environmental impacts. Source: Own elaboration

Figure 4.4 Contribution of direct and indirect effects to total effects of STE and NGCC. Source:

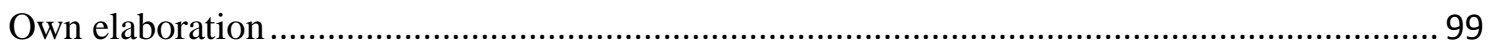

Figure 4.5 Contribution of effects inside and outside Mexico to total effects of STE and NGCC.

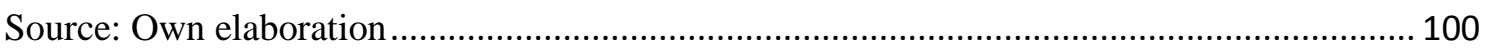

Figure 4.6 Contribution of effects of the investment and O\&M phases to total effects of STE

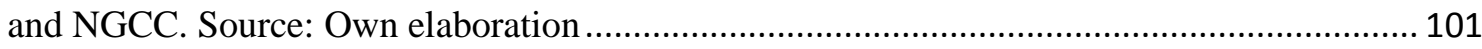

Figure 5.1. "Framework for Integrated Sustainability Assessment" methodological steps.

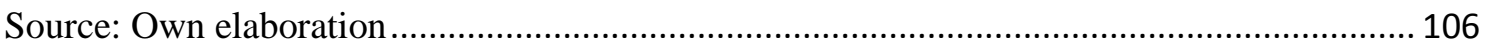

Figure 5.2 FISA results of total effects for STE and NGCC in Mexico. Source: Own elaboration

Figure 5.3 Differences between NGCC and STE scores in each pillar regarding the three

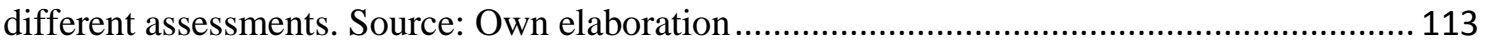

Figure 5.4 Total points achieved for each assessment for STE and NGCC. Source: Own elaboration.

Figure 5.5 Ratio of worse score achieve by NGCC from STE in each type of assessment.

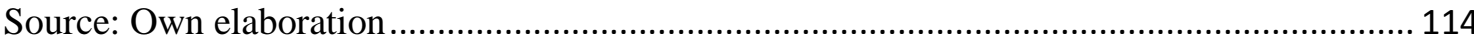

Figure 5.6 Priorities obtained from FISA, weighting and ranking assessments. Source: Own

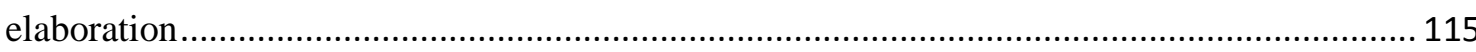

Figure 5.7 Comparison among FISA results, weighted preferences and ranking preferences.. 116 


\section{Acronyms}

ASE

AV

CFE

CIEMAT

COP

CSS

DEU

DNI

ESAU

ESTELA

FISA

GTAP

GDP

GHG

IEA

ILO

INDC

IPCC

IRENA

IUCN

LCA

MEX

MRIO

MRIOT

MUS\$

NGCC

NLD

NREL

NMVOC

O\&M
Aggregated Sustainability Endpoints

Added Value

Comisión Federal de Electricidad (Mexico)

Centro de Investigaciones Energéticas, Medioambientales y

Tecnológicas

Conference of the Parties

Country Specific Sectors

Germany

Direct Normal Irradiation

Energy Systems Analysis Unit

European Solar Thermal Electricity Association

Framework for Integrated Sustainability Assessment

Global Trade Analysis Project

Gross Domestic Product

Green House Gases

International Energy Agency

International Labor Organization

Intended Nationally Determined Contribution

Intergovernmental Panel on Climate Change

International Renewable Energy Agency

International Union for Conservation of Nature

Life Cycle Assessment

Mexico

Multiregional Input Ouput

Multiregional Input Ouput Table

Million dollars (United States)

Natural Gas Combined Cycle

The Netherlands

National Renewable Energy Laboratorie (USA)

Non-Methane Volatile Organic Compounds

Operation and Maintenance 
OECD Organisation for Economic Co-operation and Development

PG\&S Production of Goods and Services

PSA Plataforma Solar de Almería

PSH Project Social Hotspots

PSI Project Social Index

RE Renewable Energy

RoW Rest of the World Region

SENER Secretaría de Energía (Mexico)

SHDB Social Hotspot Database

SOLARPACES Solar Power and Chemical Energy Systems

STE Solar Thermal Electricity

UNEP United Nations Environment Program

USA United States of America

UPM Universidad Politécnica de Madrid

WH Working Hours

WIOD World Input Output Database

WIOT World Input Output Table 


\section{Introduction}

\subsection{Motivation}

According to the Brundtland report, sustainable development is defined as "the one that meets the needs of the present without compromising the ability of future generations to meet their own needs" (World Commission on Environment and Development 1987). According to this objective, countries' development should be guided in a way that economic aspects matter as much as the environmental and social ones. Despite some degree of controversy mainly related to the equal consideration of the three dimensions by the different interests of stakeholders, (Herman 1997; Adams 2006; Vucetich and Nelson 2010), since it was first introduced in 1987, this "sustainable development thinking" has been gradually gaining supporters worldwide while becoming one of the priorities in the agendas of international, national and local decision makers as well as other relevant stakeholders (United Nations 2016a).

Nowadays, achieving a sustainable development worldwide seems like a difficult endeavor as the excessive and unsustainable consumption patterns in many developed countries together with the increasing population and industrial development in many parts of the developing world is putting additional pressures on the earth's finite resources. Additionally, in our global market, ensuring sustainability is a difficult task since many products and services are manufactured in developing countries where lower production costs are often achieved due to weaker environmental and social protection laws. Furthermore, this problem is exacerbated by the generalized lack of awareness about the environmental and social problems embedded in many supply chains as consumers are not conscious about the consequences of their purchasing decisions. Some of the most tangible consequences of this unsustainable economic growth include climate change and the increasing social inequality between developed and undeveloped countries.

Over the last few years, in light of the above mentioned global challenges, various sustainability assessment methods as well as related studies have emerged (Jørgensen et al. 2008; Hansmann et al. 2012; Carraro et al. 2013; Linke et al. 2013; Macombe et al. 2013; Graymore 2014; Chhipi-Shrestha et al. 2015; Sawaengsak and Gheewala 2017). Despite the value of such studies, they are not exempt of some 
methodological or conceptual limitations. According to Weaver and Rotmans (2006), Integrated Sustainability Assessment (ISA) methods aim at conducting an analysis of the three dimension of sustainability in a integrative way while accounting for multilevel processes and including stakeholders' participation (Weaver and Rotmans 2006). Hacking and Guthrie (2007) proposed a framework to classify sustainability studies, including comprehensiveness of the coverage, integratedness of the methods and themes and strategicness of the aim and scope of the case studies. Starting from the comprehensiveness of the dimensions covered, many of the studies are found to only consider one dimension, mainly bio-physical environmental aspects (Govender et al. 2006) or two sustainability dimensions, integrating also the socioeconomic perspective. Even when the three pillars are accounted for, not all of them are covered and treated with the same degree of detail, specially social dimension, which is hardly included or only analyzed in terms of socioeconomic (mainly labor) aspects (Bezerr 2012; Duscha et al. 2014; Sawaengsak and Gheewala 2017). Other studies suggest the inclusion of a fourth dimension related to governance and institutional issues (IISD 2002). Regarding the integratedness, some of the studies analyze each sustainability pillar but not in an integrative way or only integrate two of the three dimensions (Weidema 2006; Sawaengsak and Gheewala 2017). In a strategicness point of view, the broad of the studies vary from a micro perspective (e.g. project specific impacts) to a macro scale (e.g. regional/global impacts). In this sense, when conducting a comprehensive sustainability assessment, one needs to consider the whole supply chain involved in the production of goods and services regardless of where the different life cycle stages take place. Finally, most of the existing sustainability assessment studies take place in developed countries and the extrapolation of the impact results to developing countries is not adequate due to the different contexts (underlying economic structure, cultural aspects, regulation, resilience of ecosystems, etc.)

One of the methodologies which accounts for the different effects taking place in all the countries involved along the supply chain of products and services is Multiregional Input Output Assessment (MRIO). MRIO allows to estimate changes in the global economy resulting from an increase in the demand of goods and services in a given region (Tukker and Dietzenbacher 2013). From this economic stimulation, the analysis can be extended to analyze the derived socioeconomic and environmental impacts (Ten Raa 2006). There exist other methodologies that allow to estimate these 
effects such as, for example, Social Accounting Matrix (SAM), which accounts for the transactions between production factors, economic sectors and final demand (Uriel et al. 2003; Cardenete and Fuentes 2009). However, SAM's main limitation is related to its extensive data requirement (Cardenete and Fuentes 2009), leading to a further focus on a national scope rather than a global scope (Barboza-Carrasco et al. 2009; Cardenete and Fuentes 2009).

Historically, among the relevant products and services susceptible of having a sustainability impact assessment, energy has been and will continue to be one of the key drivers for economic development. However, energy has traditionally been produced and consumed in an unsustainable manner mainly due to its fossil fuel dependence, which is responsible for large amounts of Green House Gases (GHG) emissions (Dreger 2010). For this reason, the energy sector is the largest contributor to climate change (IRENA 2016), the most acute environmental problem the world is facing today. This is of crucial importance because the consequences of climate change are already hampering the progress towards, among others, poverty reduction and economic grow, especially in the most vulnerable countries (United Nations 2016a).

The recent Paris Agreement of the past COP 21 has set multilateral paths to combat climate change from a global perspective. The main objective established in the agreement is that the global average temperature increase does not exceed $2^{\circ} \mathrm{C}$ in the long term and preferable limited to $1.5^{\circ} \mathrm{C}$ (United Nations 2015). Almost 200 countries joined this agreement, but the estimated emission reductions within the Intended Nationally Determined Contributions (INDT) reported by participants are not sufficient to accomplish the temperature rising target below $2^{\circ} \mathrm{C}$ (United Nations 2015). For this reason, besides energy efficiency improvements and Carbon Capture and Storage (CSS) technologies, an even further deployment and integration of renewable energies (RES) is needed to combat mitigate GHG emissions (SENER 2013).

When considering the generation costs, most renewable technologies are still not cost competitive with fossil fuels (Caldés and Lechón 2010; International Energy Agency and Nuclear Energy Agency 2015; IRENA 2015). Thus, in order to foster the deployment of RES and design effective and efficient renewable support policies, it is necessary to go beyond the private costs and take into consideration the social costs which implies the consideration of the external environmental and socio-economic repercussions (IRENA 2016). In a nutshell, it is utterly important that, when decision 
makers choose between alternative energy technologies investments, they take into account the whole set of consequences across the three sustainability pillars. This need is particularly relevant in developing countries where their current and future economic and population growth will be accompanied by an increasing energy demand (SENER 2013).

Despite the multiple benefits of renewables energies, the intermittent generation of most renewable energies is the main disadvantage for the energy system management. In this sense, Solar Thermal Electricity is expected to play an important role as a dispatchable technology thanks to its energy storage capacity (ESTELA 2016). According to a recent study, STE is expected to supply $5 \%$ and $12 \%$ of the world power demand for 2030 and 2050 respectively (Greenpeace et al. 2016). This technology will be especially relevant in the so called "solar belt" countries with direct irradiations levels higher to $2,500 \mathrm{kWh} / \mathrm{m}^{2}$. Within the "solar belt", one of the countries with higher solar energy potential is Mexico (Romero-Hernández et al. 2012; Secretaría de Economía 2013; ESTELA 2014).

Having in mind the above mentioned concerns, more research is needed to better account for the three sustainability dimensions of impacts involved in the supply chains of the production of goods and services. Additionally, there is a need to apply such sustainability assessment frameworks to energy technologies in developing countries so that decision makers can take informed judgements.

To respond to the above mentioned research gaps, this thesis proposes a sustainability impact assessment framework named FISA (Framework for Integrated Sustainability Assessment). In a nutshell, FISA allows to assess, for any given project, impacts across the three sustainability dimensions taking into consideration the whole supply chain of products and services while accounting for the international trade. Additionally, the validity and usefulness of the proposed framework will be tested through its application to Solar Thermal Electricity production in Mexico.

\subsection{Research questions}

Taking into account the described context, this thesis is structured around two cornerstones: the "Framework for Integrated Sustainability Assessment" (FISA) which is described in Chapter 2; and its different application to Solar Thermal Electricity (STE) production in Mexico within Chapters 3, 4 and 5. 
First, Chapter 2 describes the state of the art related to sustainability assessments. The identified methodological gaps and limitations frame the advantages and disadvantages of the proposed Framework for Integrated Sustainability Assessment "FISA". Next, methodological steps of the proposed FISA is presented, which captures, in an integrative way, the economic, environmental and social impacts embedded in the supply chain of the production of any goods and services. Thus, Chapter 2 aims at answering the following research questions:

- RQ1. Given the cost data of any investment project, is the proposed Framework for Integrated Sustainability Assessment (FISA) able to account for its associated impacts within the three pillars of sustainability?

- $\quad$ RQ2. Is FISA able to account for the sustainability impacts of goods and services taking into consideration the international trade embedded throughout the whole supply chain?

- $\quad$ RQ3. How can FISA outputs/results support decisions making processes?

In the next chapter, the applicability and validity of the methodological framework is assessed by analyzing the sustainability impacts of Solar Thermal Electricity (STE) plant in Mexico. Chapter 3 aims at answering the following questions:

- $\quad$ RQ4. Which are the most relevant socioeconomic, environmental and social effects involved in the whole supply chain of STE production in Mexico?

- RQ5. Which sectors and countries are more stimulated within each sustainability pillar?

- $\quad$ RQ6. Are the results comparable to similar case studies from the literature?

- $\quad$ RQ7: What recommendations can be derived from the results in order to improve the sustainability performance of STE in Mexico?

In Chapter 4, FISA results from STE case study are compared to those resulting from the electricity production with Natural Gas Combined Cycle in Mexico. This comparison aims to support decision making processes when alternative investment choices are presented. The research questions addressed in Chapter 4 are: 
- RQ8. What are the main differences between the sustainability performances of the STE compared to the Natural Gas Combined cycle electricity production?

- RQ9. When comparing technologies, which sectors and countries are more stimulated in each sustainability pillar?

- RQ10. What energy policy recommendations can be derived from the comparative assessment?

Finally, Chapter 5 aims at assessing the usefulness of the outputs generated by FISA for decision makers. For this purpose, the answers of a questionnaire conducted to a group of Mexican decision makers in the energy sector are analyzed in order to assess the relevance that they gave to the various impacts (criteria) analyzed in FISA. In summary, this chapters aims at answering the following research questions:

- RQ11. Which are the stakeholders' revealed preferences about sustainability criteria considered in FISA?

- $\quad$ RQ12. Which technology achieves the poorest sustainability score?

- RQ13. Have interviewees changed their opinion about relevant sustainability criteria after seeing the proposed FISA impacts?

- RQ14. Have interviewees suggested other criterions to be included in the FISA framework?

\subsection{Structure of the thesis}

Figure 1.1 displays the links between the research questions and the thesis' chapters. 


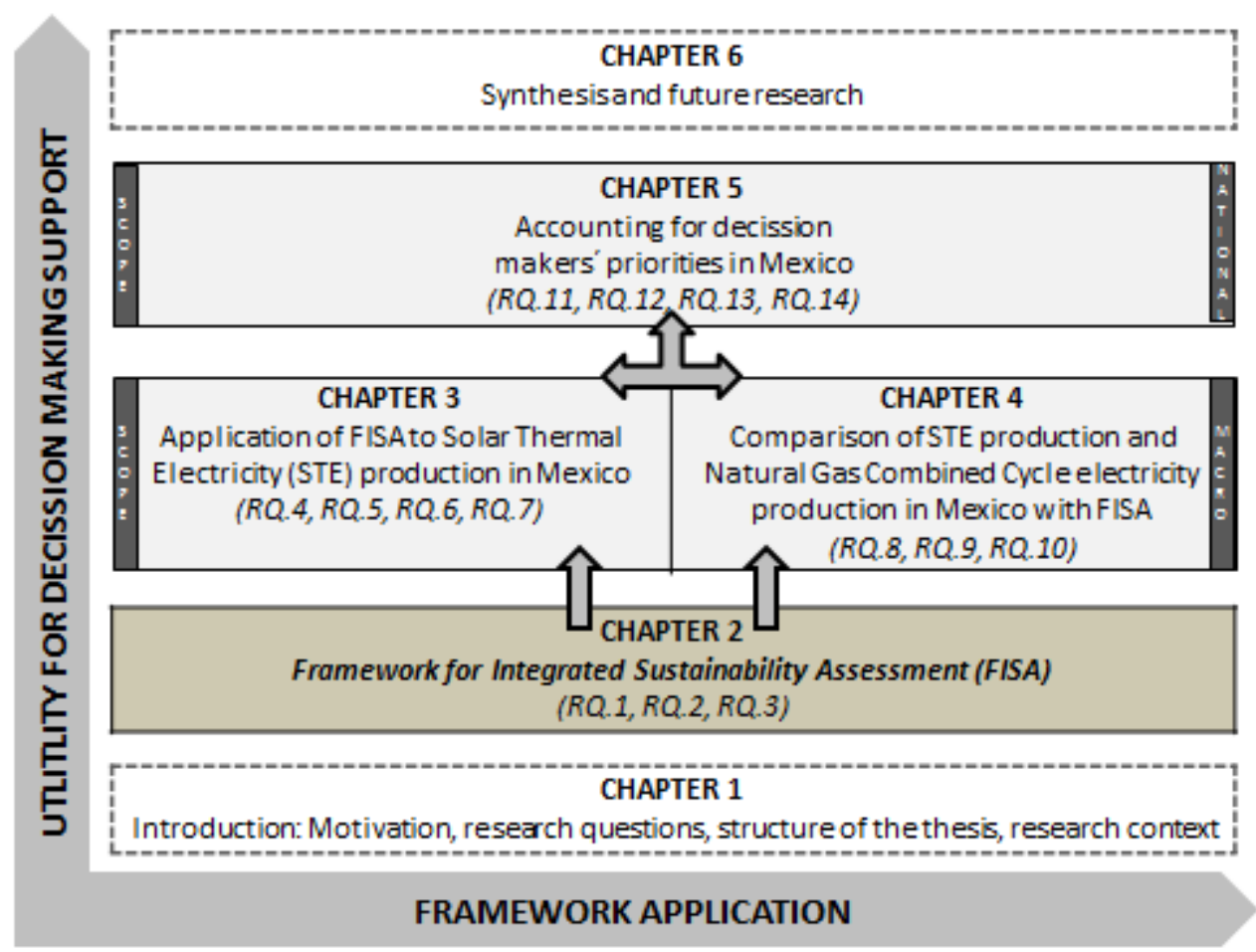

Figure 1.1 Structure of the thesis. Source: own elaboration

\subsection{Research context}

The context of thesis was initiated towards the end of 2012 when I was awarded with a two-years FPI (Formación de Personal Investigador) grant at CIEMAT (Centro de Investigaciones Energéticas, Medioambientales y Tecnológicas) in Madrid. As part of this grant, I obtained a Master degree in Agricultural and Natural Resources Economics from the Agronomist Engineering Technical School (ETSIA) of the Universidad Politécnica de Madrid (UPM). As part of the MsC, my Master Thesis was conducted within the Energy System Analysis Unit (ESAU) at the Energy Department at Ciemat, co-directed by Dr. Natalia Caldés (CIEMAT) and Dr. Alberto Garrido (UPM). This MsC thesis was the basis for the later $\mathrm{PhD}$ research which was based on the Input-Output methodology, solar energy as well as the assessment of socioeconomic, environmental and social impacts. This $\mathrm{MsC}$ thesis, titled "Socioeconomic, environmental and social impacts of a concentrated solar power energy project in Northern Chile", was later published in the journal "Renewable Energy and Environmental Sustainability” (Rodríguez-Serrano et al. 2016a). 
As a way to enlarge my knowledge about sustainability studies and, in particular, in social assessments in developing countries, from August to December 2014, I had the opportunity to pursue part of my graduate studies at the University of California, Berkeley, as a visiting scholar at the Center for Latin American Studies. While at Berkeley, I had the opportunity to learn from professors and experts who apply different methodologies to assess the social dimension of energy projects. Additionally, I had the chance to attend courses and seminars related to energy as well as to environmental sciences.

From the end of 2014 to date, I have had an employment contract in Ciemat in which I conducted this $\mathrm{PhD}$ thesis research. During this period, I have gained the knowledge required to develop the FISA framework and apply it to different case studies. This research work has been conducted within ESAUnit-CIEMAT under the technical supervision of Dr. Cristina de la Rúa, Dr. Yolanda Lechón, and specially Dr. Natlia Caldés, who also provided continued thesis supervision as co-director. As my second co-director, Dr. Alberto Garrido, from UPM, has also contributed to the accomplishment of this $\mathrm{PhD}$.

Collaborations with the European Solar Energy Association (ESTELA) as well as with researchers from the Plataforma Solar de Almería (PSA-CIEMAT) were of crucial importance as they provided critical advice and the data needed for the STE case study. In the same way, the collaboration with Autonomic University of Morelos in Mexico was of critical importance for the case study in Mexico as they supported NGCC techno-economic data as well as facilitated the consultation process with Mexican decision makers. Finally, the questionnaire conducted in this research work (see Appendix 5.2) was jointly developed with the Computer Systems Unit at CIEMAT and the CISOT-Ciemat team in Barcelona (Centro de Investigaciones Socio-Técnicas), which provided valuable support during the questionnaire design, interview process and analysis of the results.

The thesis results were presented (1) in a conference in Ciemat which took place on June $10^{\text {th }}$ in Madrid; (2) in a workshop of the Life Cycle Network which took place on June $23^{\text {rd }}$ in Madrid; and (3) in the 2016 SolarPaces congress, from $11^{\text {th }}$ to $16^{\text {th }}$ October, in Abu Dhabi. 


\subsection{Statement on Publications involved in this thesis}

The chapters within this thesis have an article form, which are published or under review processes in different journals. A statement of the publications contribution to each chapter is described below.

Chapter 2: Framework for Integrated Sustainability Assessment (FISA): Methodological steps

Published in Environment, Development and Sustainability. Rodríguez-Serrano, I., Caldés, N., De la Rúa, C., Lechón, Y., Garrido, A. Using the Framework for Integrated Sustainability Assessment (FISA) to expand the Multiregional Input-Output analysis to account for the three pillars of sustainability (2016). DOI :10.1007/s10668-016-9839-y

Chapter 3: Application of FISA to Solar Thermal Electricity (STE) production in Mexico

Article in press in Journal of Cleaner Production. Rodríguez-Serrano, I., Caldés, N., De la Rúa, C., Lechón, Y. Assessing the three sustainability pillars through the Framework for Integrated Sustainability Assessment (FISA): case study of a Solar Thermal Electricity project in Mexico. 149 (2017) 1127-1143. DOI 10.1016/j.jclepro.2017.02.179

Chapter 4: Comparison of STE production and Natural Gas Combined Cycle electricity production in Mexico with FISA

Under review in Journal of Energy for Sustainable Development. Rodríguez-Serrano, I., Caldés, N., De la Rúa, C., Lechón, Y. Sustainability impact assessment of alternative Solar Thermal Electricity and Natural Gas Combined Cycle electricity production in Mexico.

\section{Chapter 5: Accounting for decision makers' priorities in Mexico}

Accepted in AIP Conference Proceedings Journal. Rodríguez Serrano, I., Caldés, N., Oltra, C., Sala. R. Comparing the sustainability impacts of solar thermal and natural gas combined cycle for electricity production in Mexico: accounting for decision makers' 
priorities. Presented as oral form in the International Conference SolarPaces 11-16 Oct, Abu Dhabi and Accepted for publication on December 2016. 


\title{
2. Using the Framework for Integrated Sustainability Assessment (FISA) to expand the Multiregional Input-Output analysis to account for the three pillars of sustainability ${ }^{1}$
}

\begin{abstract}
Decision makers interested in promoting sustainable development must simultaneously consider the environmental, economic and social implications of any action. This article proposes the Framework for Integrated Sustainability Assessment (FISA), a methodological framework for conducting a sustainability impact assessment of any investment project. Based on a Multiregional Input-Output (MRIO) framework, FISA links the extended MRIO results with social risk data from the Social Hotspots Database (SHDB) in order to integrate the social with the environmental and economic pillars. Resulting impacts are simultaneously considered and reported by means of FISA charts, making it possible to assess the different impacts within the three sustainability pillars across countries involved in the whole supply chain of investment projects. This methodological framework can be applied not only to compare the sustainability impacts of two alternative projects but also to derive specific recommendations aimed at minimizing the harmful social, environmental and economic effects along the whole project supply chain.
\end{abstract}

Key words: Sustainability; Multiregional Input-Output; Social Assessment; Supply Chains, Decision Making Support.

\footnotetext{
${ }^{1}$ Published in Environment, Development and Sustainability journal, $16^{\text {th }}$ August 2016. Co-authored with Natalia Caldés, Cristina de la Rúa, Yolanda Lechón (Energy Systems Analysis Unit, Energy Department, Technical, Environmental and Energy Research Centre (CIEMAT)) and Alberto Garrido (Department of Agricultural Economics and Social Sciences, Universidad Politécnica de Madrid (UPM)). Authors would like to thank reviewers for their valuable comments.
} 


\subsection{Introduction}

Sustainability is an integrative concept which considers that responsible development requires a balanced consideration of environmental, social and economic aspects (World Commission on Environment and Development 1987; Kajikawa 2008; Schoolman et al. 2012). Striking this balance is far from easy as the three pillars involve different types of values that are not commensurable with each other. Also the controversial interests of different stakeholders frequently conflict within a single pillar of sustainability (Vucetich and Nelson 2010). While this challenge is universal, developing countries face important pressures to exploit their environmental resource base for profits. Their economies rely heavily on their natural resources, and they have laxer social and environmental protection laws (Lehman 1999). As a consequence, their rapid economic growth often comes at the expense of irreversible environmental and social damage. Furthermore, globalization and outsourcing have increased the complexity of supply chains and the amount of interaction between industrialized and developing countries. In a global market, products and services consumed in developed countries are likely to be based on factors of production in developing countries that might result in not only environmental impacts but also social abuses due to weaker social protection measures, for example, low salaries (Oxfam 2013; Alsamawi et al. 2014). Besides, developing countries are often challenged by different priorities usually related to meeting their most basic needs (Oxfam 2013).

In this context, decision-making practices that emphasize solely economic and environmental impacts fail to capture many fundamental social issues in developing countries (e.g., need for equity, education and infrastructures). Practices such as corporate social responsibility were devised to address this issue by monitoring social and environmental conditions throughout the entire supply chains within companies (Elkington 1998). Even so, law enforcement is still insufficient in these countries, and most businesses do not meet their ethical responsibilities (Friedman 1970), although enforcement measures in supply chains are increasing through supply chain reporting (Spence and Bourlakis 2009). However, while field visits or auditing are useful ways to qualitatively explore the specific social conditions of businesses or factories — such as working conditions-, they are of no use if a general overview of a whole industry or economic sector is required. 
For the above reasons, it is of utmost importance for decision makers to have the right tools to measure and consider the three pillars of sustainability associated with any investment decision. In this respect, the research question to be addressed is, "Given the cost data of any investment project, is there a methodological framework which outputs simultaneously capture its economic, environmental and social impacts?"

The proposed Framework for Integrated Sustainability Assessment (FISA) is able to capture not only economic and environmental impacts but also the associated social impacts by assessing the potential social risks from trade across economic sectors worldwide. Additionally, FISA results are reported simultaneously. The three sustainability pillars can be compared across all economic sectors and countries involved in the whole supply chain of projects.

\subsection{State of the art}

Methodologies aimed at assessing the three types of impacts have developed at different paces. While methodologies that assess the financial and economic dimensions of an investment project were developed many decades ago (e.g., project finance, life-cycle costing, activity-based costing, traditional input-output analysis, etc.), efforts to quantify, monetize and later internalize environmental and socioeconomic externalities are more recent. The early studies focused mainly on assessing greenhouse gases (GHG) and other local emissions (Hohmeyer 1988; Bernow and Marron 1990; Ottinger et al. 1990; Pearce et al. 1992; ETSU and METROECONOMICA 1995; NEEDS 2009), and job creation (Stone 1986; Duscha et al. 2014; Teske et al. 2014; Ferroukhi et al. 2015), for example. Besides, other social aspects (e.g., quality of employment, poverty, long working hours, etc.) have started to be accounted for (Senhbruch 2004; Dreyer et al. 2006; Cohen 2009; Hutchins and Sutherland 2009; Bezerr 2012; Casillas and Kammen 2012; Linke et al. 2013; Oxfam 2013).

Table 2.1 shows a compilation of early studies singling out the pillar of sustainability that they address. While the first set of studies considered only the economic dimension, the following group also accounted for (both or either) the environmental and social dimensions. Table 1 also highlights the associated limitations when considering a complete and simultaneous sustainability assessment. 
Table 2.1 Literature review of methodologies assessing one or more pillars listing barriers to a complete and simultaneous sustainability assessment

\begin{tabular}{|c|c|c|c|}
\hline Pillar covered & Studies & Methodology & $\begin{array}{l}\text { Barriers for a simultaneous sustainability } \\
\text { assessment }\end{array}$ \\
\hline \multirow{2}{*}{ Economic } & $\begin{array}{l}\text { (Stanford University 2005) } \\
\text { (Leontief 1936) } \\
\text { (Shakya et al. 2005) }\end{array}$ & $\begin{array}{l}\text { Life Cycle Costing } \\
\text { Input Output (IO) } \\
\text { Financial analysis }\end{array}$ & \multirow{2}{*}{ A focus on economic impacts } \\
\hline & (Caldés et al. 2006) & Activity-based costing & \\
\hline $\begin{array}{l}\text { Environment } \\
\text { with/without } \\
\text { economic } \\
\text { pillar }\end{array}$ & $\begin{array}{l}\text { (Hong et al. 2013) } \\
\text { (Jala and Nandagiri 2015) } \\
\text { (Munda 1996) } \\
\text { (Esmaeili and Shahsavari } \\
\text { 2011) }\end{array}$ & $\begin{array}{l}\text { Life Cycle Assessment (LCA) } \\
\text { Travel cost method and } \\
\text { contingent assessment } \\
\text { Cost-Benefit Analysis (CBA) } \\
\text { Hedonic price method }\end{array}$ & $\begin{array}{l}\text { A focus on environmental impacts with/without } \\
\text { economic issues }\end{array}$ \\
\hline \multirow{10}{*}{$\begin{array}{l}\text { Social pillar } \\
\text { with/without } \\
\text { economic or } \\
\text { environment } \\
\text { pillars }\end{array}$} & $\begin{array}{l}\text { (Alsamawi et al. 2014) } \\
\text { (De la Rúa Lope 2009) }\end{array}$ & $\begin{array}{l}\text { Extended MRIO } \\
\text { LCA and IO }\end{array}$ & $\begin{array}{l}\text { An exclusively employment-related social } \\
\text { perspective }\end{array}$ \\
\hline & (Caldés et al. 2009) & Extended IO & $\begin{array}{l}\text { A focus on exclusively economic and employment } \\
\text { impacts }\end{array}$ \\
\hline & (Casillas and Kammen 2012) & $\begin{array}{l}\text { Carbon abatement cost curve } \\
\text { and equity metrics }\end{array}$ & $\begin{array}{l}\text { Availability of carbon cost curves and social } \\
\text { indicators of regions/countries } \\
\text { No simultaneous impact assessment }\end{array}$ \\
\hline & \multirow{3}{*}{$\begin{array}{l}\text { (Dreyer et al. 2006) } \\
\text { (Hutchins and Sutherland } \\
2009) \\
\text { (Cohen 2009) }\end{array}$} & LCA & A focus on exclusively social impacts \\
\hline & & LCA, IO, indicators, modeling & $\begin{array}{l}\text { No simultaneous impact assessment } \\
\text { Social indicators availability }\end{array}$ \\
\hline & & $\begin{array}{l}\text { Multidimensional Poverty } \\
\text { Assessment Tool }\end{array}$ & $\begin{array}{l}\text { A focus on exclusively social impacts } \\
\text { Time and expensive (based on interviews) }\end{array}$ \\
\hline & \multirow{3}{*}{$\begin{array}{l}\text { (Linke et al. 2013) } \\
\text { (Bezerr 2012) } \\
\text { (Weidema 2006) } \\
\text { (Senhbruch 2004) }\end{array}$} & Indicators & $\begin{array}{l}\text { A focus on exclusively employment-related impacts } \\
\text { Indicator availability (very specific processes) }\end{array}$ \\
\hline & & LCA and CBA & A focus on social and economic aspects \\
\hline & & Indicators & $\begin{array}{l}\text { A focus on exclusively employment-related social } \\
\text { concerns }\end{array}$ \\
\hline & (Mc Bain 2015) & Extended MRIO and indicators & No simultaneous sustainability impact assessment \\
\hline
\end{tabular}

Source: Own elaboration 
As shown in Table 2.1, most methodologies conduct a partial sustainability assessment and do not cover all three pillars. The main methodological challenge is to expand and integrate social impact assessment with the other pillars, whose root is the specification of boundary definitions and the availability of data regarding some social concerns (Lehman 1999). Besides, most social impacts are based on qualitative results from surveys or field visits. They cannot be straightforwardly converted to quantifiable results and integrated with traditional economic or environmental methodologies. Also, qualitative data is often more subjective and more locally specific than quantitative values (UNEP et al. 2009). Additionally, according to some authors, data collection for most social databases is neither robust, consistent nor reliable (Ranis and Stewart 2010). Furthermore, most of the existing social indexes have significant calculation errors due to data uncertainty (e.g., the Human Development Index (Wolff et al. 2010)), data transformation (e.g., the Social Vulnerability Index (Tate 2012)), and the disparity of methods used (Smith et al. 2013; McBain and Alsamawi 2014). For example, some indexes employ an aggregation methodology based on subjective expert evaluations (Carraro et al. 2013). Finally, few methodologies take into account all the stages of the supply chains across various sectors and countries (Alsamawi et al. 2014).

In the light of the above challenges, the FISA methodological proposal presented in this paper broadens the existing body of literature and helps to fill the social gap by integrating this pillar into sustainability assessments. To do this, Multiregional Input-Output (MRIO) analysis is the selected overarching methodology, as it can account for a wide variety of socioeconomic and environmental impacts across countries and sectors based on project cost data. Next, the social pillar is integrated by combining MRIO results with the Social Hotspots Database social risk database. As a result, the economic sectors and countries most stimulated by the analyzed projects with high social risks are identified and named Project Social Hotspots (PSH). Through this methodological integration, the three types of impacts caused by investment projects are accounted for across economic sectors around the world.

The remainder of the paper is structured as follows. Section 3 presents the methodological steps of the proposed FISA. First, the Multiregional Input-Output (MRIO) methodology and the Social Hotspots Database social risk database are explained. Next, the methodological integration and FISA charts are described and the FISA results are simultaneously plotted. Finally, FISA's role in decision-making 
processes, future applications of the methodological framework and the main conclusions are presented.

\subsection{Methodological integration: Framework for Integrated Sustainability Assessment (FISA)}

Figure 2.1 illustrates the methodological steps of the proposed sustainability framework. Based on investment and operations and maintenance (O\&M) cost data as the specific project inputs, the Multiregional Input-Output (MRIO) methodology can assess the response of all economic sectors across several countries to an increase in the demand for goods and services using MRIO tables (MRIOT). An extension of the MRIO methodology accounts for the socioeconomic and environmental impacts by adding vectors related to $\mathrm{CO}_{2}$ emissions, employment or working hours per dollar produced for each sector and country, for example. The social pillar is later incorporated into the FISA methodological framework by linking the MRIO results with social risk data from the Social Hotspots Database (SHDB) classified by countries and sectors according to the World Input-Output Database (WIOD). This analysis is capable of identifying Project Social Hotspots (PSH). PSHs represent the sectors that will be both highly stimulated by the analyzed project and associated with high social risks. The different effects caused by the analyzed projects are compared simultaneously using FISA charts. Such illustrations can provide decision makers with support when considering and comparing the impacts of alternative projects across the three sustainability pillars. 


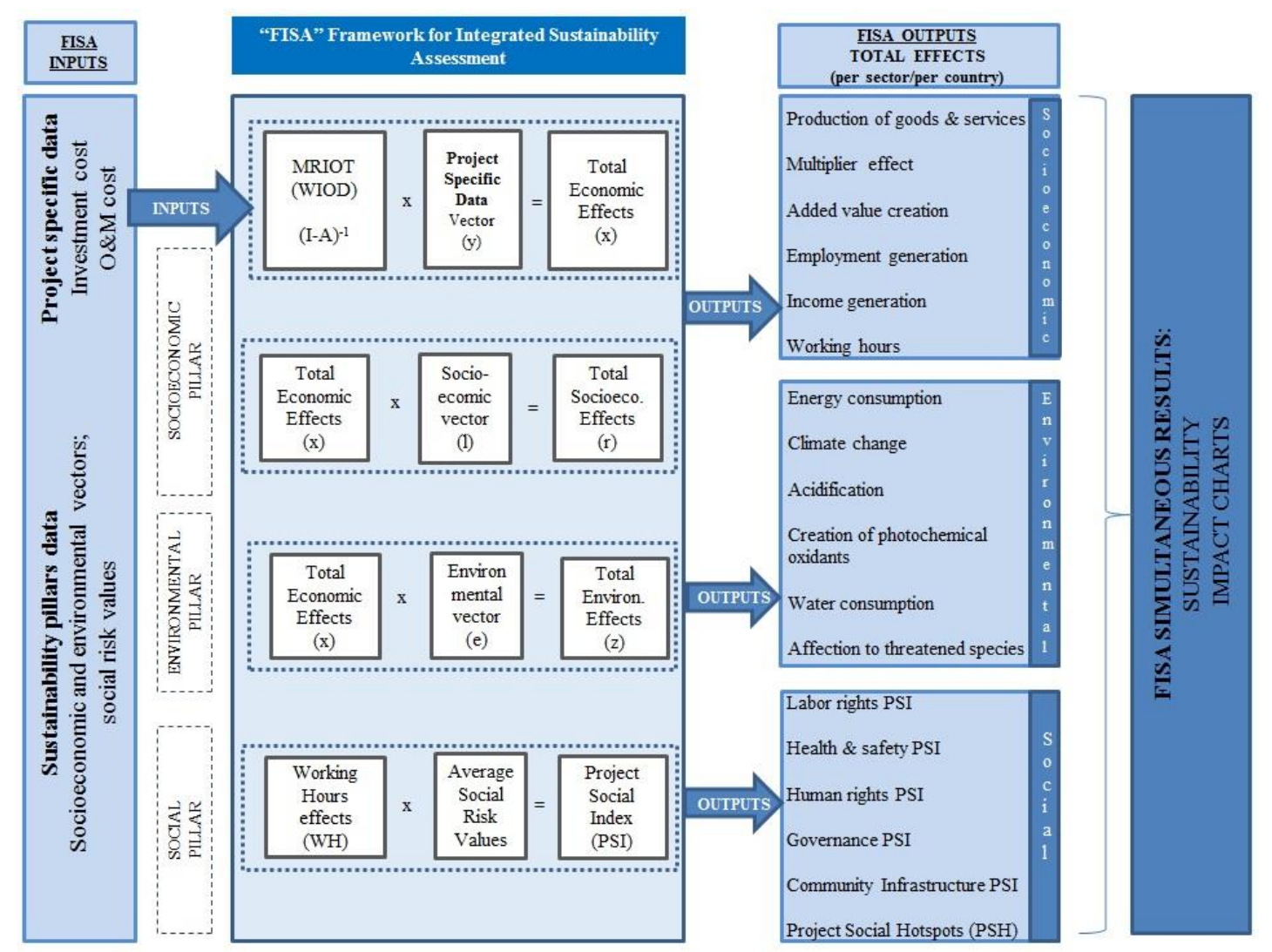

Figure 2.1 Methodological integration through FISA. Source: Own elaboration

\subsubsection{Multiregional input-output model (MRIO)}

The Input-Output (IO) methodology analyzes the response of economic sectors in a region or country caused by a change in the demand for goods and services generated by a project (Ten Raa 2006). This methodology was first developed in 1936 by Wassily Leontief, who studied the relations among the US economic sectors between 1919 and 1929. His work was based on IO Tables (IOT), which show the relation between consumption or inputs and production or outputs among the economic sectors of an economy. Technical coefficients can be calculated from the IOT. The technical coefficients indicate the intermediate consumption that one sector requires from another sector to produce one single monetary unit (Leontief, 1936).

Leontief's traditional IO model was expanded to account for trade among different regions or countries through a Multiregional Input-Output (MRIO) analysis (Isard 1951). The first studies using MRIO assessment date from the 1950s, when MRIO is considered as an extension of the traditional IO model analyzing not only trade among economic sectors but also among different regions using Multiregional Input- 
Output Tables (MRIOT) (Moses 1955). This geographical expansion is extremely relevant in the light of globalization, increasing competition in product manufacturing and growing trade flow among countries (Navarro 2012).

Based on traditional input-output tables, MRIOT combine endogenously domestic technical coefficient matrices with import-export matrices from multiple countries or regions, capturing world trade supply chains between all economic sectors of all trading partners (Álvarez 2014).

Table 2.2 shows the typical structure of a Multiregional Input-Output Table.

Table 2.2 Typical structure if a MRIOT

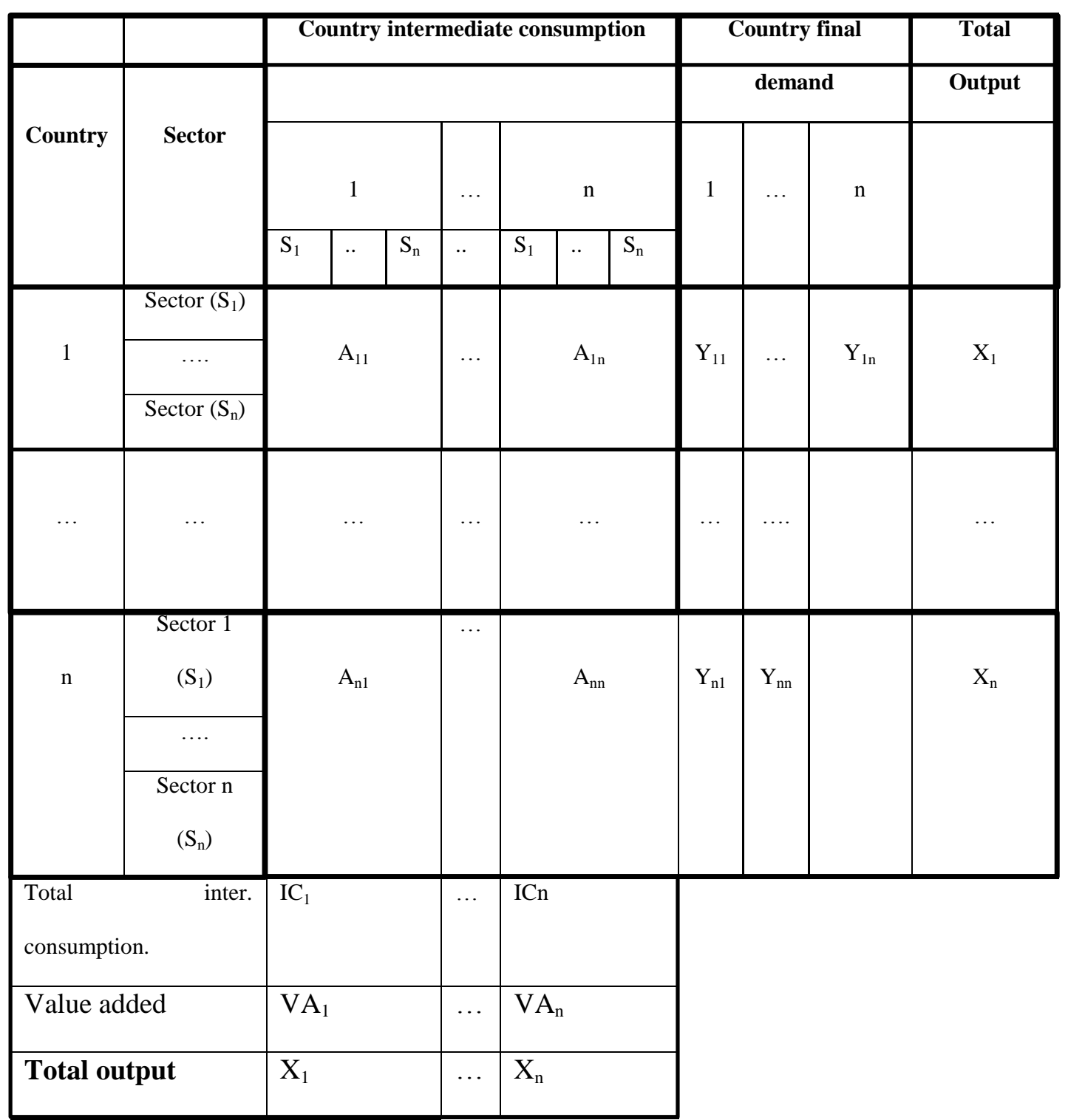

Source: Own elaboration based on the WIOT from WIOD 
The intermediate consumption section refers to the trade among countries and sectors. The diagonal contains the domestic matrices $\left(\mathrm{A}_{\mathrm{nn}}\right)$, which show the trade among sectors within the same country. Outside of the diagonal, the matrices cover the trade among sectors of the different countries $\left(\mathrm{A}_{\mathrm{nm}}\right)$.

Traditional IO tables contain the domestic matrix of a country. The domestic matrix includes the national technical coefficients, which has $\mathrm{R} \times \mathrm{R}$ dimensions depending on the number of domestic economic sectors within the analyzed country. These technical coefficients indicate the intermediate consumption that one sector requires from another sector to produce one single unit monetary unit within a country (Equation (2.1)) (De la Rúa Lope 2009).

$$
a_{i j}=x_{i j} / x_{j}
$$

where $\mathrm{X}_{\mathrm{ij}}$ is the amount of product that the economic sector $\mathrm{j}$ requires from the economic sector $\mathrm{i}$ to generate its final production $\mathrm{X}_{\mathrm{j}}$, and $\mathrm{a}_{\mathrm{ij}}$ is the amount of product that the economic sector $\mathrm{j}$ requires from the economic sector $\mathrm{i}$ to produce one unit of product $\mathrm{j}$.

In MRIO tables, domestic and import matrices within countries are combined endogenously, and their technical coefficients integrate relations among their sectors (Equation (2.2)) (Álvarez 2014).

$$
a_{i j}^{m n}=X_{i j}^{m n} / X_{j}^{n}
$$

where $x_{i j}{ }^{m n}$ is the amount of product that the economic sector $j$ of the country $n$ requires from the economic sector $i$ of the country $m$ to generate its final production $\mathrm{X}_{\mathrm{j}}^{\mathrm{n}}$, and $\mathrm{a}_{\mathrm{ij}}^{\mathrm{mn}}$ is the amount of product that the economic sector $\mathrm{j}$ of the country $\mathrm{n}$ requires from the economic sector i of the country $m$ to produce one unit of product $\mathrm{jn}$.

With all technical coefficients included in the MRIO tables, the initial domestic matrix $R \times R$ becomes an $R r \times R r$ matrix, which accounts for the trade among sectors and different countries. Finally, a country's total output includes the relations among the 
intermediate consumption of sectors and countries and the demand from households, governments and non-profit organizations (Equation (2.3)).

$$
\mathrm{X}=\mathrm{AX}+\mathrm{Y}
$$

where $\mathrm{X}$ is a country's production, $\mathrm{A}$ is the MRIO technical coefficient matrix, and $\mathrm{Y}$ is the household, government and non-profit organization demand vector. This equation takes into account the intra- and interregional relations among sectors in the different countries (Miller and Blair 2009).

Equation (3) can be also formulated as the Leontief equation (Equation (2.4)).

$$
\mathrm{X}=(\mathrm{I}-\mathrm{A})^{-1} \cdot \mathrm{Y}
$$

where $(\mathrm{I}-\mathrm{A})^{-1}$ is the Leontief inverse matrix, which quantifies the total economic effects $\mathrm{X}$ of the investment project $\mathrm{Y}$.

While $\mathrm{X}$ depicts the total (direct and indirect) increase in the demand for goods and services generated by an investment project $\mathrm{Y}$, it is also possible to estimate the increase in added value by considering $X$ and the corresponding share of added value per sector. Additionally, due to the interdependency among economic sectors, the development of any project involves a general stimulation of economic sectors. This is the so-called multiplier effect and indicates by how much the economic activity of a country increases for every monetary unit invested in a project. The multiplier effect is the ratio between total effects (direct and indirect effects) and direct effects (X/Y), where direct effects (Y) are effects related to the principal demands for the project and indirect effects are the inputs necessary to satisfy direct demand (X-Y) (Holland and Cooke 1992).

\subsubsection{Extended MRIO: environmental and socioeconomic pillars}


Once the total economic impacts (e.g., total gross domestic/import demand, added value, multiplier effect) associated with an investment project have been estimated, the methodology can be expanded to account for other non-economic effects by considering socioeconomic and environmental vectors $\left(\mathrm{Z}_{\mathrm{i}}\right)$. These vectors are constructed from environmental or socioeconomic data $\left(\mathrm{CO}_{2}\right.$ emissions, employment, etc.) per unit of economic output for each economic sector in each country. The associated impacts are estimated by multiplying the above vectors by the total economic effect generated by the project (Equation (2.5)) (Caldés \& Lechón, 2010).

$$
\mathrm{Z}_{\mathrm{t}}=\mathrm{Z}_{\mathrm{i}} \cdot(\mathrm{I}-\mathrm{A})^{-1} \cdot \Delta \mathrm{Y}
$$

where $\mathrm{Z}_{\mathrm{t}}$ is the total (direct and indirect) socioeconomic or environmental impact analyzed (employment,...) and $\mathrm{Z}_{\mathrm{i}}$ is the environmental or socioeconomic vector, which indicates the employment, emissions, energy consumption, etc., per unit of production for each economic sector.

The first studies that estimated socioeconomic impacts using an IO methodology dated from the 1960s (Stone 1966). Recently, the International Energy AgencyRenewable Energy Technology Deployment (IEA-RETD) project referred to the IO methodology as one of the most robust tools for assessing job creation and the cost and benefits of alternative scenarios or different energy technologies (Breitschopf et al. 2012). With regard to environmental concerns, the first analysis conducted using MRIO focused on the inventory of emissions of a huge range of sectors and countries, e.g. OECD countries (Wyckoff and Roop 1994), Japan (Kondo et al. 1998) or Australia (Lenzen 1998), from a consumer point of view. The increasing interest in the environmental effects of trade has led to an increase in this type of methodological approaches like MRIO applied to environmental impacts (Lenzen 1998; Andrew et al. 2009; Hertwich and Peters 2009; Wiedmann et al. 2010; Feng et al. 2011; Zafrilla et al. 2014). Finally, other social effects are starting to be accounted for (Alsamawi et al. 2014; Mc Bain 2015).

One of the MRIO's methodological advantages is that it accounts for a wide range of supply chains of products and services across all involved countries (Alsamawi 
et al. 2014). However, the MRIO methodology is not without certain limitations. Some are that it assumes unlimited production capacity, it does not account for the possibility of storage, it does not account for all informal transactions in the economy and the IOT are only published every few years (Holland and Cooke 1992). Additionally, the sectorial aggregation involves identical impacts assumed for all activities included in each economic sector (Corona et al. 2016a). Despite these limitations, this framework has been widely used to predict future impacts (Barrett et al. 2013) and support decision-making processes (Baumol and Wolff 1994), as well as for identifying key economic sectors (Archer and Fletcher 1996; Kofoworola and Gheewala 2008).

Of particular relevance for this research is the World Input-Output Database $(\text { WIOD })^{2}$. This multiregional database provides Multiregional Input-Output Tables of forty countries, as well as socioeconomic and environmental accounts like employment, GHG emissions, and energy and water consumption. The World Input-Output Database (WIOD) is a European Commission project developed by a consortium of eleven European research institutions (Arto et al. 2014). It covers 35 economic sectors within 40 countries plus a Rest of World (RoW) region from the period 1995 to 2011. Although there are other databases, like the Global Trade Analysis Project (GTAP) (Gehlhar 1996), one of the advantages of the World Input-Output Database (WIOD) is that its world input-output tables are based on supply and use tables (SUTs) from national accounts statistics based on sector level supply and demand data. They are later integrated with bilateral trade statistics, leading to fewer discrepancies between sectorial GDP data in their IOTs and national statistics (Jones et al. 2014). By using SUTs from national accounts, data can be harmonized over time series (Erumban et al. 2012b). Multiregional IOTs from GTAP are not based on SUTs from national account statistics, but are constructed from country IOTs usually provided voluntarily by researchers. They are later adjusted with trade statistics and macroeconomic data from several sources (World Bank, International Trade Center's MAcMap system, etc.) (Huff et al. 2000; Harslett 2013). Because GTAP is not benchmarked on national accounts statistics, discrepancies between GTAP computed GDPs and national statistics have been reported to be around 5-10\%, while WIOD result 1\% (Jones et al. 2014). Additionally, the different versions of GTAP databases are inconsistent, which is an

\footnotetext{
${ }^{2}$ http://www.wiod.org/new_site/home.htm
} 
obstacle to the use of data for historical comparisons. Other differences between databases are the availability of Multiregional IOTs (GTAP multiregional IOTs are available every three years and WIOD MRIOTs are available every year). Additionally, the WIOD database is publicly accessible. However, WIOD has fewer sectorial disaggregation (35 sectors for WIOD vs. 57 sectors for GTAP). This could play an important role in environmental impact assessments, mainly with respect to agricultural or energy sector disaggregation. Besides, WIOD contains fewer countries, predominating mostly European countries, and the RoW aggregation is a limitation if a specific impact assessment of a country, primarily developing countries, is required (Tukker and Dietzenbacher 2013).

\subsubsection{Expanding the social pillar: linking MRIO results with the Social} Hotspots Database

When assessing the social effects of any economic activity, there is a need to explore beyond socioeconomic variables like the numbers of jobs created (UNEP et al. 2009). One way to do this is by linking the total effects estimated by the MRIO assessment with the Social Hotspots Database (SHDB). The SHDB quantifies social risks for every Country-Specific Sector (CCS).

The first version of the SHDB was created in 2011 by New Earth ${ }^{3}$ and was later improved in 2013. It contains a wide variety of social indicators mainly based on public data from institutions such as the International Labor Organization (ILO), World Bank (WB) and other organizations that periodically gather large volumes of social data (Franze 2013). The indicators are classified into 22 social themes based on the United Nations Environment Programme (UNEP) guideline and five impact categories (UNEP et al. 2009), as shown in Table 2.3.

Table 2.3 SHDB impact categories and social themes

\footnotetext{
${ }^{3} \mathrm{http}: / /$ socialhotspot.org/
} 


\begin{tabular}{|c|c|c|c|c|c|}
\hline \multicolumn{6}{|c|}{ Impact Categories } \\
\hline \multirow{8}{*}{$\begin{array}{l}\text { Social } \\
\text { Themes }\end{array}$} & $\begin{array}{l}\text { Labor rights } \\
\text { and decent } \\
\text { work }\end{array}$ & $\begin{array}{l}\text { Health and } \\
\text { safety }\end{array}$ & $\begin{array}{c}\text { Human } \\
\text { rights }\end{array}$ & Governance & $\begin{array}{l}\text { Community } \\
\text { infrastructure }\end{array}$ \\
\hline & Child labor & & & & \\
\hline & Forced labor & & $\begin{array}{l}\text { Indigenous } \\
\text { rights }\end{array}$ & & Hospitals \\
\hline & Excessive & $\begin{array}{l}\text { Injuries and } \\
\text { fatalities }\end{array}$ & & Legal system & \\
\hline & $\begin{array}{l}\text { working time } \\
\text { Wage } \\
\text { assessment } \\
\text { Poverty }\end{array}$ & & $\begin{array}{l}\text { High } \\
\text { conflicts }\end{array}$ & & Drinking water \\
\hline & Migrant labor & & Gender & & Sanitation \\
\hline & $\begin{array}{l}\text { Freedom of } \\
\text { association }\end{array}$ & $\begin{array}{l}\text { Toxics and } \\
\text { hazards }\end{array}$ & equality & Corruption & $\begin{array}{c}\text { Children out of } \\
\text { school }\end{array}$ \\
\hline & $\begin{array}{c}\text { Unemployment } \\
\text { Labor laws }\end{array}$ & & $\begin{array}{l}\text { Human } \\
\text { health } \\
\text { issues }\end{array}$ & & $\begin{array}{l}\text { Smallholders vs } \\
\text { commercial farm }\end{array}$ \\
\hline
\end{tabular}

Source: Own elaboration based on the SHDB

The selection of indicators within social themes is based on the comprehensiveness of the indicator — data availability in the economic sectors and countries-, data source legitimacy, data collection reliability, the possibility of quantifying the indicators and relevance with respect to the investigated theme. There are a great many different types and forms of social indicators, ranging from human rights to gender equality, and from qualitative to quantitative or semi-quantitative indicators (Franze 2013).

According to the SHDB methodology, the identification of social hotspots across sectors within one country is based on the analysis and conversion of social indicators to social risk values (Benoît et al. 2012). Social risk values are figures that represent the existence and degree of different social threats occurring in economic sectors. There are four levels of social risk values, represented on a quantitative scale: low risk (1), medium risk (2), high risk (3) or very high risk (4). These social risk values are obtained by means of a process of characterizing and normalizing the different social indicators, based mainly on the data distribution (e.g.,. quartiles). Depending on the type and form of the social indicator (quantitative, semi quantitative, qualitative, etc.), other approaches are also used (e.g., expert consultation) (Franze 2013). More 
information about the processes of transformation and types of social risk is available from New Earth (2013). Thus, a wide variety of social issues are quantified and categorized on the same risk scale. It is therefore possible to compare and identify the highest social risks within economic sectors and countries across supply chains (GreenDelta 2013). However, this methodology also has some limitations. They include missing data for some CSS, the use of obsolete data or error accumulation throughout social risk quantification (data collection errors, uncertainty in databases, conversion into quantitative data, etc.) (Franze 2013), or the use of qualitative data, which may be biased by some degree of subjectivity (UNEP et al. 2009). Additionally, it also suffers from the same constraints as most social databases, as mentioned by Ranis \& Stewart (2010) and Wolff et al. (2010).

Until now, social risk values have only been available for the GTAP classification $^{4}$ of countries and sectors (see, for example, Benoît et al. (2012)). Thus, one of the contributions of this paper is the use of social risk values for WIOD sectors and countries and their direct linkage with a MRIO assessment of a specific project through FISA. FISA is capable of identifying Project Social Hotspots (PSH), namely the sectors with the highest social risk values in the economic sectors most stimulated by a specific project. These PSHs are identified by calculating the Project Social Index (PSI). The PSI is computed by multiplying the extended MRIO working hours results (WH) by the average social risk values in each CSS per impact category. Of all the possible socioeconomic variables, we selected working hours as the indicator for calculating the PSI, as it reflects labor stimulation and gives a better overview of the sectors that are more vulnerable to particular social risks. In this respect, the economic sectors with the highest PSI values correspond to the PSHs. These are, at the same time, (i) the sectors most stimulated by the project in terms of $\mathrm{WH}$ and (ii) the economic sectors with the highest social risk values.

Compared to previous analyses using the SHDB (Benoît et al. 2012), this paper is the first to use social risk values for WIOD economic sectors and countries. Besides, the resulting PSHs round out the traditional extended MRIO assessment by expanding the social impacts to other aspects beyond employment, income and working hours. From this assessment, it is then possible to identify, for any given investment project,

\footnotetext{
${ }^{4}$ https://www.gtap.agecon.purdue.edu/
} 
which sectors require special attention (PHSs) either because they are calculated by the PSI to have the heaviest burden in terms of working hours or prominent social risks. Figure 2.2 shows the proposed SHDB-MRIO linkage.

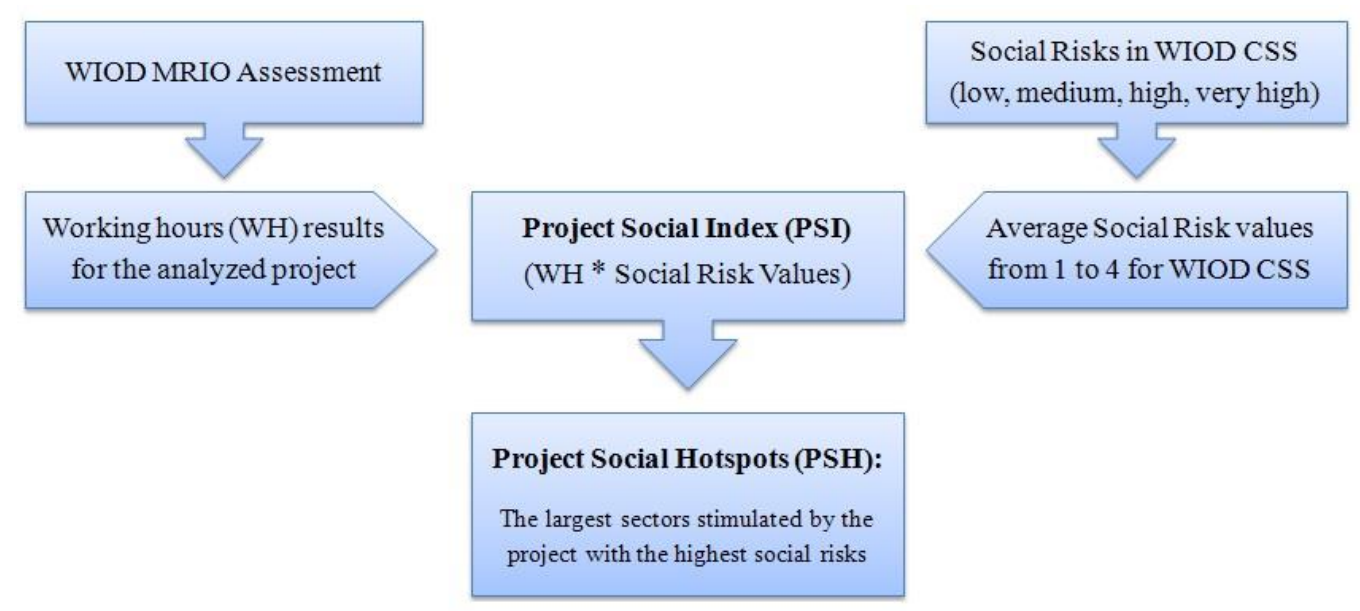

Figure 2.2 SHDB-MRIO linkage with WIOD countries and sectors. Source: Own elaboration

A possible example of PSH identification would be a project stimulating the "Renting of machinery and equipment and other business activities" WIOD sector through machinery hire, architecture or engineering services, among other activities. According to the MRIO assessment, this sector accounts for a large percentage of the total working hours across the whole project, that is, in both the investment and operational phases. Additionally, the "Construction" sector is also highly stimulated in terms of working hours, but accounts for a smaller proportion because the construction phase is shorter. Moreover, both sectors have a high average social risk value within all five impact categories, although the figure for the "Construction" sector is higher. After multiplying the respective $\mathrm{WH}$ and averaged social risk values in both sectors, the final PSI of both sectors is similar. This means that both sectors account for a large proportion of WH and also have high social risk values, and both are therefore PSHs. Then, it is possible to explore the highest risk values within the PSHs in order to find out which specific social issues require more attention.

Once the three types of impacts have been assessed, FISA charts consider all impacts simultaneously. The three impacts types are integrated together into the same FISA charts by comparing the specific effects of each type of impact over its effects. 
FISA charts could help decision makers to easily take into account that, for example, environmental and social impacts could differ widely even if alternative projects have similar figures for economic stimulation. In this case, it is possible to explore which project phases, types of effects or countries are responsible for the largest share of impacts. This could steer decision-making processes towards the selection of the best project from a sustainability point of view, as well helping with the identification of harmful effects. Figure 2.3 shows the combined impacts through FISA charts.

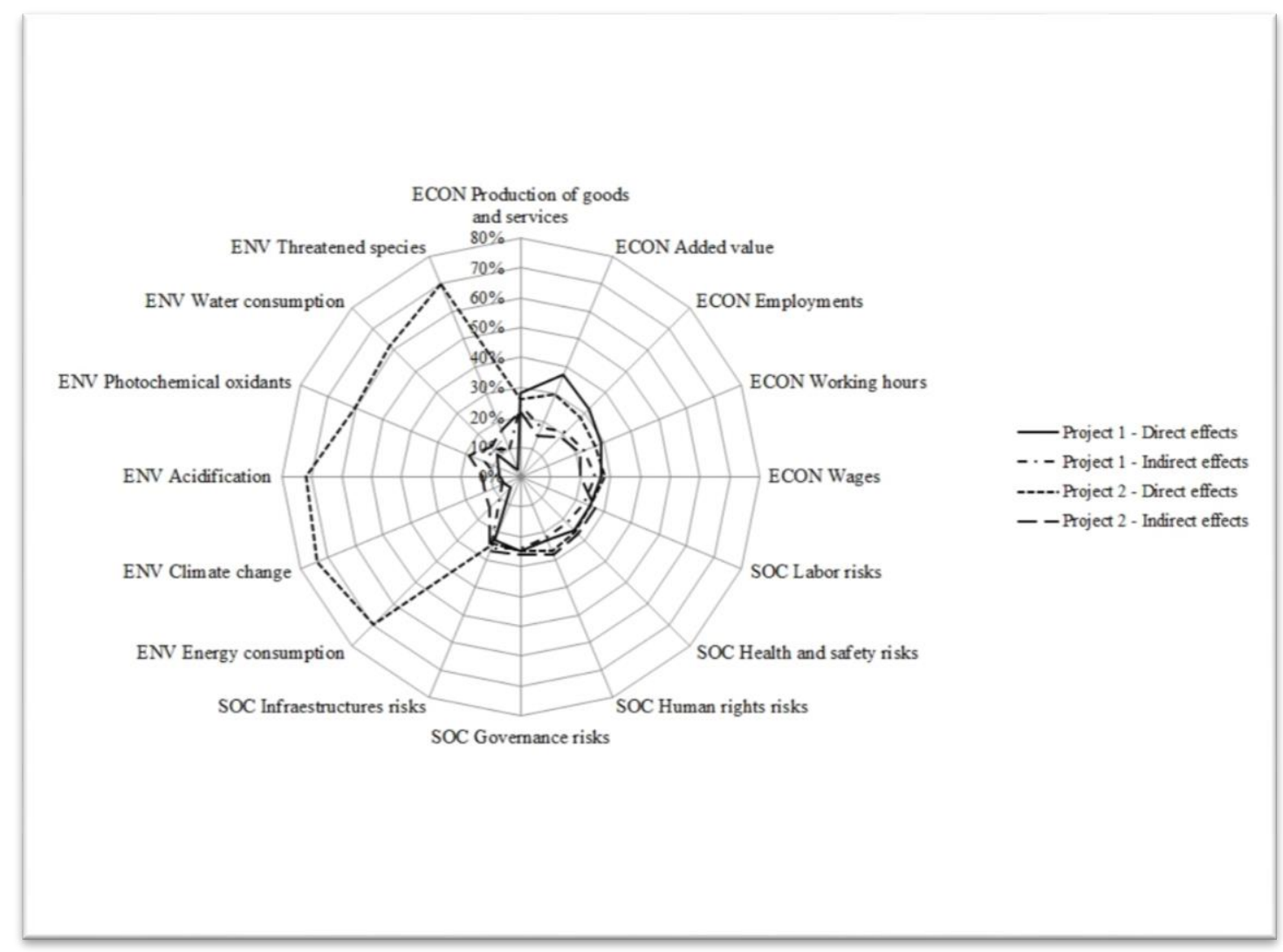

Figure 2.3 Combined impacts trough FISA chart. Source: Own elaboration

Figure 2.3 is an example of a possible chart plotting FISA results. This chart shows the economic, environmental and social impacts of two hypothetical investment projects. It illustrates the proportion of direct and indirect effects over the total effects on each impact within the three sustainability pillars associated with the different projects. Other possible charts may single out the effects across countries or project phases. An immediate future line of research in this paper is the application of this methodological framework to specified case studies. 
In a nutshell, FISA's strength is that it provides the possibility of integrating economic, environmental and social impacts which can be reported simultaneously by means of FISA charts. In this manner, different effects among the sustainability pillars can be compared along the whole supply chain of specific investment projects. This is possible thanks to the use of an extended MRIO analysis, whereby socioeconomic and environmental impacts can be estimated based on project cost data inputs. Additionally, these impacts are also estimated within the social pillar by linking MRIO working hour results with social risk values from the SHDB to identify PHSs. They pinpoint the riskiest economic sectors most stimulated by the development of the project. Accordingly, a wide range of output effects can be singled out: direct, indirect or induced effects across the investment or operational phases of the projects; impacts occurring on a national or international scale caused by domestic or imported components, as well as related impacts from trade relationships between countries.

Despite the advantages of this approach, it has some limitations related to sector aggregation. In this respect, the assumption of unique social risk values within each economic sector does not necessarily match up with all activities or industries aggregated in the respective sector. Additionally, this assumption does not account for the possibility of companies having different social responsibility practices within the same sector.

Given the globalized market, the application of the proposed methodological framework FISA to specified investment projects is expected to generate relevant results for decision makers as many projects import goods and services (either directly or indirectly) from developing countries, which often have laxer environmental and social protection legislations. The FISA results are able to account for such trade relationships and track the potential positive and most important harmful effects throughout the whole supply chain. As such, the use of this framework could make decision makers aware of the possible sustainability effects of their actions, both nationally and globally, in order to take the necessary measures to minimize the negative effects while fostering the positive impacts.

Another future line of research will focus on accounting for key stakeholder opinions and preferences in the results derived from FISA. According to Graymore (2014), stakeholders should be included in the development of sustainability methods, 
as they should bear in mind the priorities of counties and societies (Graymore 2014). In this way, the significance of the results produced by FISA will be assessed by key stakeholders (e.g., policy makers) through a preference questionnaire. Additionally, this exercise will compare the raw FISA results with the FISA results weighted to account for stakeholder preferences stated in the questionnaire. However, the limitations of this approach, such as possible lack of transparency or the potential subjectivity of expert evaluations and weighting processes, must also be considered (Carraro et al. 2013).

\subsection{Conclusions}

Sustainability is no longer a stranger to decision-maker agendas, and most stakeholders recognize the need to account for the economic, environmental and social implications of the decisions that they make in a globalized world. Consequently, any comprehensive sustainability assessment should account for the impacts of any project across the three sustainability pillars along supply chains linking producers with final consumers. One consideration of such assessments is the evaluation of the environmental and social impacts embodied in the traded commodities.

In this context, MRIO models are good at assessing the socioeconomic and environmental impacts of global trade. They should, however, integrate the social pillar, and this poses a methodological challenge.

In this respect, the research reported here contributes to expanding the existing body of literature by proposing the integration of MRIO analysis with social risks from the SHDB through the Framework for Integrated Sustainability Assessment (FISA). Based on the cost figures of the analyzed project, FISA estimates more than fifteen types of impacts within the three sustainability pillars, singling out direct and indirect effects, project phases and countries where the respective effects are felt. The results generated by the proposed framework also help to improve the understanding and communication of the complex relations among the three sustainability pillars. Additionally, it is useful for comparing the impacts of two alternative projects. In particular, it can identify the key impacts within the three sustainability pillars, while taking into account the whole supply chain and existing global trade. In this way, FISA 
aims to provide decision makers with support for choosing the best alternative taking into consideration the three sustainability pillars along the whole supply chain.

Future research lines will focus on the validation of the proposed framework through its application to alternative projects and an expert evaluation of its use in decision-making processes. 


\title{
3. Assessing the three sustainability pillars through the Framework for Integrated Sustainability Assessment (FISA): case study of a Solar Thermal Electricity project in Mexico ${ }^{5}$
}

\begin{abstract}
The aim of this paper is to conduct a sustainability impact assessment of the supply chain of a Solar Thermal Electricity (STE) project in Mexico using the "Framework for Integrated Sustainability Assessment" (FISA). The estimation of the economic, environmental and social impacts along the supply chain makes it possible to identify the sustainability hotspots both from direct effects as well as indirect effects while considering the international trade within the different project phases. Results show that the largest socioeconomic effects but also social risks would occur in Mexico mainly as a result of direct effects during the investment phase. On the contrary, most environmental impacts would take place outside Mexican borders, mainly caused by indirect activities related to the investment phase. The results from this assessment could help decisions makers take into account not only direct impacts of the Solar Thermal Electricity project but also the indirect ones occurred throughout the supply chain. Additionally, by equally accounting for the economic, environmental and social dimensions, the assessment could help them identify the sustainability hotspots and guide them towards implementing the required actions and measures to improve the sustainability performance of the project.
\end{abstract}

Key words: Input-Output; Integrated Assessment; Sustainability Hotspots; Supply Chains; Mexico Solar Thermal Electricity; Decision Making Support

\footnotetext{
${ }^{5}$ Article in press in Journal of Cleaner Production, 24 February 2017. Co-authored with Natalia Caldés, Cristina de la Rúa and Yolanda Lechón (Energy Systems Analysis Unit, Energy Department, Technical, Environmental and Energy Research Centre (CIEMAT)). Authors would like to thank ESTELA and the PSA for their technical support and reviewers for their valuable comments.
} 


\subsection{Introduction}

When talking about sustainable development, the existing interlinkages between economy, environment and society require the simultaneous consideration of the three sustainability pillars in a conceptual as well as in a quantitative way (Mihelcic et al. 2003).

In the recent years, the interest in assessing the three dimensions of sustainability has been increasing. Purely environmental impact assessment tools such as the Environmental Life Cycle Assessment Methodology (ELCA), one of the preferred methodologies to evaluate the environmental sustainability of products and services, are currently being extended to include the other dimensions of sustainability through the development of the so called Life Cycle Sustainability Assessment (LCSA) (UNEP and SETAC 2011). The LCSA proposed by the UNEP-SETAC initiative comprises the realization of an Environmental Life Cycle Assessment, Life Cycle Costing (Swarr et al. 2011) and Social Life Cycle Assessment (UNEP et al. 2009). There is an extensive literature on ELCA applied to a wide variety of products (Lifset 2012). Similarly, the Life Cycle Costing method has been widely applied (Korpi and Ala-Risku 2008) and some applications of Social Life Cycle Assessment can be found in the literature (Macombe et al. 2013; Manik et al. 2013). However, complete LCSA assessments are still scarce (Traverso et al. 2012; Ostermeyer et al. 2013) and subject to methodological limitations (Guinée 2015).

Similarly, other methodologies originally designed to capture macroeconomic impacts of investments, such as Input Output Analysis, have been extended and hybridized in order to include environmental effects (Lenzen 1998; Wiedmann et al. 2007). The incorporation of the social perspective in this type of assessments has been mostly conducted by accounting for socioeconomic impacts in terms of job creation (Thornley et al. 2008; Alsamawi et al. 2014; Duscha et al. 2014; Ferroukhi et al. 2015) and the inclusion of additional social impacts is still very incipient (Papong et al. 2015).

Recently, various sustainability assessment methodological approaches have been developed (Kuitunen et al. 2008; Bezerr 2012; Hansmann et al. 2012; Carraro et al. 2013; Linke et al. 2013; Graymore 2014). Despite the value of such studies, they are not exempt of some methodological or conceptual limitations. Even when the three pillars 
of sustainability are accounted for, in most cases, not all of them are covered and treated with the same degree of detail, specially social impacts (Bezerr 2012; Linke et al. 2013) Additionally, the development of most sustainability indexes employs an aggregation methodology based on expert evaluations which are not exempt of some level of subjetivity (Kuitunen et al. 2008; Carraro et al. 2013). Furthermore, due to the international trade, the environmental and social impacts of economic activities in developed countries are often offshored to developing ones. Therefore, information on the location of the different life cycle stages becomes very relevant to rigorously assess the sustainability implications of the analyzed products or services (Benoit et al. 2010; Zamagni et al. 2011; Alsamawi et al. 2014). Finally, most sustainability assessment studies are conducted in developed countries (Hansmann et al. 2012; Graymore 2014), and the extrapolation of the impact results to developing countries may lead to inadequate conclusions due to the different contexts (underlying economic structure, cultural aspects, regulation, resilience of ecosystems, etc.).

Among the relevant products and services susceptible of having a sustainability impact assessment, energy has been and will continue to be a key driver for economic growth (Belke et al. 2011). However, the unsustainable use and production of energy is responsible for important environmental and social damages, especially in developing countries (United Nations 2016a). According to estimations from the International Energy Agency (IEA), investments in the energy sector will amount to 68 trillion dollars in the period from 2015 to 2040, and most of such investments will take place in developing countries (International Energy Agency 2015). In this context, when decision makers have to choose between alternative energy technology projects, they should look beyond investment costs and take into account the associated environmental and social effects (IRENA 2015). The interest in such impacts is currently increasing, but the existing sustainability assessments are not always comparable because they often differ in the methodology used, types of impacts considered, or part of the life cycle assessed (Santoyo-castelazo and Azapagic 2014a).

One of the countries aiming for a more sustainable and low carbon energy mix is Mexico. Being one of the top ten oil producer countries, it is largely dependent and vulnerable to oil price fluctuations and is highly dependent on natural gas imports (U.S. Energy Information Agency 2014). The associated energy security and environmental 
concerns associated to this situation has motivated recent regulatory changes. Among other regulations, in 2012 and as part of the National Strategy for Climate Change, the General Law of Climate Change was published to promote renewables energies, setting the target of $35 \%$ of the electricity generation from clean energies by 2024 (Secretaría General 2012). Similarly, in 2013, an important energy reform was carried out, whose goal was to open the electricity market to private companies for electricity generation and reduce the high tariff costs (SENER 2014).

To achieve these targets, Mexico has to progressively substitute fossil fuel technologies by renewable ones. Despite its huge renewables potential (Secretaría de Economía 2015), the total installed capacity of renewables in 2015 was 16,666 MW, representing only $21 \%$ of the total electricity installed capacity, mostly from hydropower (INERE 2015). To reverse this situation, the National Energy Secretariat (SENER) expects an increase of the renewable installed capacity of 20,544 MW from 2012 to 2026 (Secretaría de Economía 2013). Moreover, according to estimates from SENER and Asia-Pacific Economic Cooperation (APEC), by 2030 renewables could have a $10 \%$ contribution in the total final energy consumption in Mexico. This figure, according to the International Renewable Energy Agency (IRENA), could increase up to $21 \%$ (IRENA and SENER 2015).

In this context, solar energy and particularly Solar Thermal Electricity (STE) has a large potential in Mexico. Included in the so called "Solar belt", this country has more than $2,500 \mathrm{kWh} / \mathrm{m}^{2}$ of Direct Normal Irradiation (DNI), especially the North Western of the country (Romero-Hernández et al. 2012; Secretaría de Economía 2013; ArancibiaBulnes et al. 2014; ESTELA 2014). Currently, STE has 5 GW installed capacity worldwide. However, according to the European Solar Thermal Electricity Association (ESTELA), with the adequate industrial development and energy efficiency improvements, STE could supply $5 \%$ of the world power demand by 2030 , increasing to $12 \%$ by 2050 (SolarPaces et al. 2016). Compared to other renewable technologies, the main advantage of STE is its storage capacity, which warranties a firm supply. Despite its high investment cost, there is a large potential for cost reduction, especially with a progressively market growth as other renewables such as wind or photovoltaics have experienced (SolarPaces et al. 2016). 
The application of the Framework for Integrated Sustainability Assessment (FISA) to a STE plant in Mexico aims at tackling some of the above mentioned sustainability methodological and case studies limitations. Having this objective in mind, three research questions are presented:

- Which are the most relevant socioeconomic, environmental and social effects involved throughout the supply chain of STE production in Mexico?

- Are STE results estimated with FISA comparable to similar case studies from the literature?

- What recommendations can be derived from the results in order to improve the sustainability performance of STE in Mexico?

The article is structured as follows: first, the underlying methodologies supporting FISA and their integration within the proposed framework are described. Next, data and assumptions considered in the STE case study in Mexico are explained. Finally, results obtained from the case study and main conclusions are presented.

\subsection{Methodology}

\subsubsection{Multiregional Input-Output model (MRIO)}

The Input-Output (IO) methodology allows to analyze the relationships and stimulation of economic sectors within a region as a result of changes in the final demand of goods and services associated to a given product or service (Wiedmann et al. 2007). It was first developed by Wassily Leontief, who first analyzed the relations among United States' economic sectors (Leontief 1936). The methodology is based on Input Output Tables (IOT), which contain information about the consumption (inputs) and the production (outputs) of all economic sectors in a given region. When several countries or regions are involved, they are called Multiregional Input Output Tables (MRIOT). These tables contain, within its columns, the inputs that one sector needs from other sectors to produce its total output, while lines contain the distribution of the output of one sector among the rest of economic sectors (Ten Raa 2006). The monetary value of products that each sector needs from other sectors to obtain one monetary unit 
of its output is represented through technical coefficients, compiled in the so called $A$ matrix (Miller and Blair 2015)

In this sense, the total output or production of goods and services can be calculated by Eq. (1):

$$
x=(I-A)^{-1} \cdot y
$$

where $x$ is the total production of goods and services, $A$ is the coefficient matrix, $(I-A)^{-1}$ is the inverse of Leontief and $y$ is the required final demand vector

Total production of goods and services includes direct effects, which are the ones related to the principal demands for the project (" $y$ " vector); and indirect effects, which are the inputs of products and services necessaries to satisfy the principal demand. The ratio of total effects over direct effects it is called multiplier effect and gives information about how much the total economy is stimulated by the analyzed project. Additionally, it is possible to calculate the induced effects, defined as the economic stimulation generated by the project employees. Induced effects are calculated taking into consideration the employees' salaries, their propensity to spend and the typical household expenditure distribution across economic sectors.

\subsubsection{Extension of MRIO: assessment of socioeconomic and environmental impacts}

An extension of the IO methodology allows to estimate socioeconomic or environmental impacts by adding vectors of the corresponding impact per monetary unit produced in each sector of the economy (e.g. employment $/ \$ ; \mathrm{CO}_{2} / \$$, etc.) to Eq. (1). These effects can be calculated by (Eq. 2):

$$
z_{t}=z_{i} \cdot(I-A)^{-1} \cdot y
$$

where $z_{t}$ is the total socioeconomic or environmental effects and $z_{i}$ is the environmental or socioeconomic vector 
One of the advantages of the IO analysis is that it accounts for not only the direct effects but also the indirect and induced effects involved in the supply chain of the production of goods and services while taking into account international trade. However, the IO methodology is not exempt of some limitations. One of the main limitations is the sectorial aggregation, which assumes the same impacts from the different goods and services in a given sector (Leontief 1955). Another limitation is that the informal economy is not accounted for (Holland and Cooke 1992). Moreover, although several input-output databases have been launched in the last decade to provide harmonized time-series IOTs for many countries (Tukker and Dietzenbacher 2013; Jones et al. 2014), the IOTs are not published and updated yearly nor the socioeconomic and environmental accounts (Suh and Nakamura 2007; Kjaer et al. 2015).

The database used for this case study is the World Input Output Database (WIOD) (Timmer et al. 2015), resulting from a European Commission funded project within the $7^{\text {th }}$ Framework Programme (WIOD 2016). It contains time-series of world input output tables from 1995 to 2011 of thirty five economic sectors in forty countries plus a Rest of the World (RoW) region. It also contains time-series socioeconomic and environmental information such as employment, energy use, air emissions or water consumption. The IOTs are based on supply-uses tables from national statistics which are later integrated with bilateral trade statistics, achieving fewer discrepancies between resulting sectorial data and national statistics. Moreover, WIOD is publicly accessible (Tukker and Dietzenbacher 2013; Jones et al. 2014). One of its limitations is that, compared to other database like the "Global Trade Analysis Project" (GTAP) or the Australian "EORA" database, WIOD contains fewer countries, especially developing countries, and has lower economic sector disaggregation. Another limitation is that some of the WIOD data, especially socioeconomic accounts, is not updated to 2011 for some countries (e.g. compensation of employees in Mexico refers to 2009). Nevertheless, other global databases do not have some of the WIOD detailed data. For example, the EORA database lacks for some socioeconomic accounts (Foran et al. 2011) and the GTAP database socioeconomic accounts are based on the 2008 ILO Yearbook (GTAP 2012). 


\subsubsection{Adding the social pillar to the Framework for Integrated Sustainability}

\section{Assessment (FISA)}

The social dimension is included in the FISA framework by accounting for the social risks involved within all economic sectors by means of the Social Hotspot Database (SHDB), a project developed from the United Nations Environment Programme (Benoit Norris et al. 2012). It contains social risk data for 22 social themes within five impact categories (SHDB 2016). Figure 3.1 displays the five social categories and their social themes.
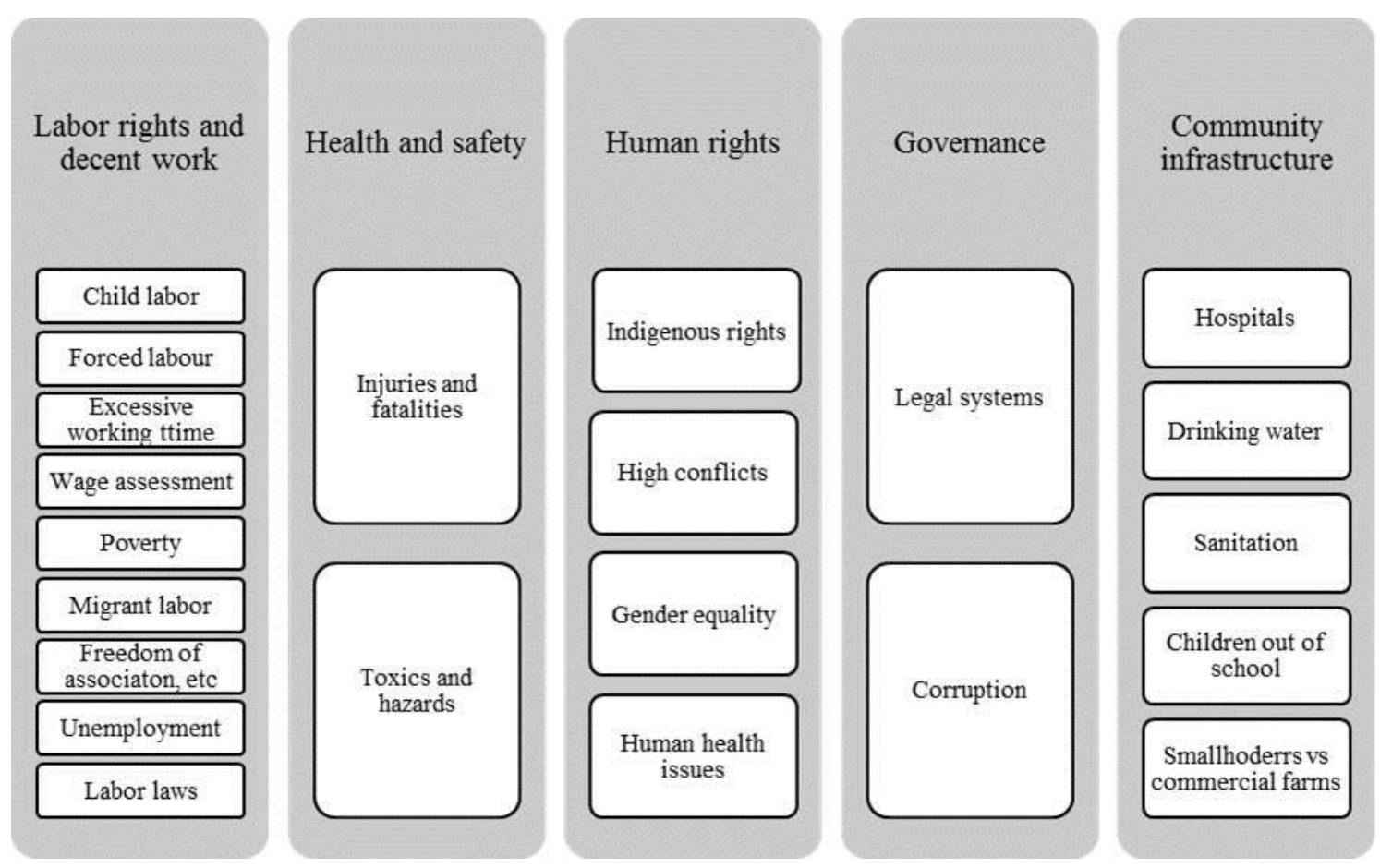

Figure 3.1 Social Hotspot Database five impact categories and social themes. Source:

Own elaboration based on the SHDB

Each social theme contains several social risks, which were obtained by a quantitative transformation of social indicators to risk values from 1 to 4 , indicating low, medium, high or very high risks respectively. Detailed information on social risks can be found in (New Earth 2013b). Despite the advantage of such wide compilation of social data and sectorial quantification of risk values, the SHDB also faces some limitations such as missing data for some countries and sectors, obsolete data for some social indicators or 
uncertainties related to data collection or its conversion to quantitative values (Franze 2013).

While previous case studies that used the SHDB considered the GTAP sectorial classification (Benoit et al. 2012), one of the added values of this work is that the social risk data of the SHDB has been assigned to WIOD sectors and countries. This fact allows to perfectly link the socioeconomic and environmental results from MRIO assessment with social risk values from the social assessment. In this sense, the methodological integration in FISA consists in linking the working hours results from the MRIO assessment with social risk values from the SHDB, obtaining the Project Social Index (PSI). In this way, high values of this index can be the result from a large socioeconomic stimulation caused by the project and also from the existence of relevant social problems over the five social categories in each economic sector, leading to the identification of harmful Project Social Hotspots (PSH) (Rodríguez-Serrano et al. 2016b).

Figure 3.2 displays the complete methodological framework distinguishing the underlying methodologies and the integration steps.

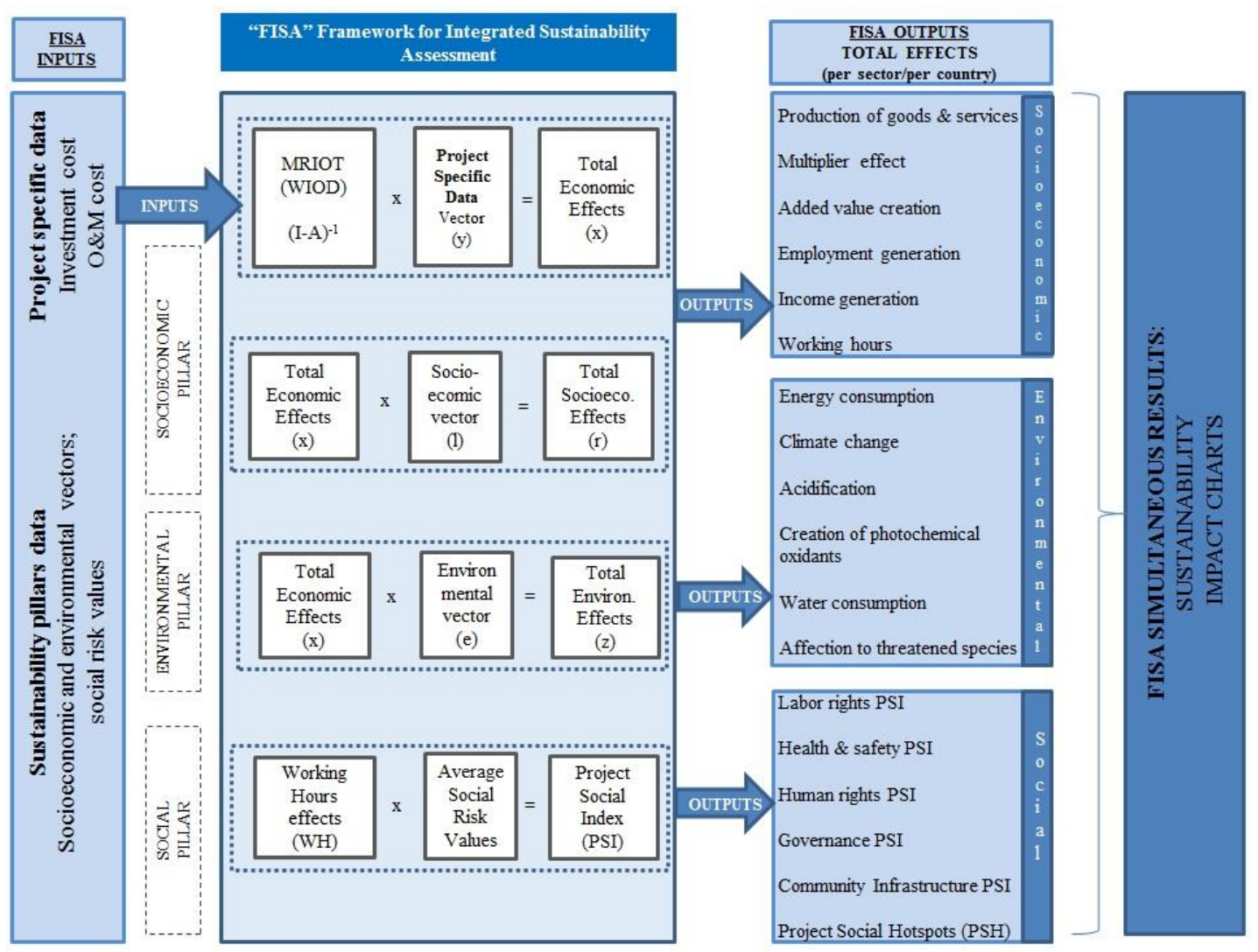


Figure 3.2 Steps of the proposed Framework for Integrated Sustainability Assessment (FISA). Source: Own elaboration

Finally, the FISA charts graphically display all sustainability impacts. These charts give simultaneous information about the potential hotspots of a specific project in the three sustainability dimensions (Rodríguez-Serrano et al. 2016b).

Thanks to the MRIO methodology, it was already possible to identify the socioeconomic and environmental effects caused by a production activity or specific project (direct/indirect effects; national or international effects within the different project phases). An added value of the FISA framework is the integration of the social dimension in the analysis, which allows to identify the potential social risks involved in sectors stimulated by the analyzed project. These social effects are then displayed together with the socioeconomic and environmental effects to identify the sustainability hotspots. However, the framework faces the methodological limitations related to the IO and SHDB involved. Of special relevance is the sectorial aggregation embedded in the IO analysis which, as explained above, assumes the same nature of impacts within a given sector. Such limitation also applies to the social perspective as social risks are assumed to be homogeneous within all activities aggregated in the same sector. Moreover, FISA results entail possible uncertainties associated the original input data and related databases (e.g.: old data within the SHDB) (Rodríguez-Serrano et al. 2016b).

\subsection{Assumptions and data sources}

\subsubsection{Location and technical configuration}

The location and technical configuration of the STE plant has been defined with the support from and consultation with experts from the Plataforma Solar de Almería (PSA) and from the European Solar Electricity Association (ESTELA). According to the consulted experts, one of the best locations for a STE plant in Mexico would be West of Hermosillo city, in the State of Sonora. Such location would meet the basic requirements: (i) Direct Normal Irradiation (DNI) higher than 2,600 kWh/m2/year (7.7 
$\mathrm{kWh} / \mathrm{m} 2 /$ day) (NREL 2016), (ii) flat desert land, (iii) close to a dense population, and (iv) communicated with electricity networks. As for the technical configuration of the plant (Table 3.1), it was defined using the System Advisor Model, assuming a typical meteorological year of the area of Tucson, Arizona, with a similar DNI (7.0 $\mathrm{kWh} / \mathrm{m}^{2 /}$ day).

Table 3.1 Basic technical configuration of the studied STE plan

\begin{tabular}{ll}
\hline Characteristics of the STE plant & \\
\hline Power & $100 \mathrm{MW}$ \\
Construction time & 2 years \\
Operational time & 30 years \\
Electricity in a year $(\mathbf{G W h})$ & 395.7 \\
Life electricity generated $(\mathbf{G W h})$ & 11871.4 \\
Occupied land area (ha) & 728.4 \\
Technology & Molten salts central receiver \\
Tower height (m) & 204.6 \\
Storage hours & 5 \\
Salts composition & $60 \%$ NaNO3, 40\% KNO3 \\
Power Cycle technology & Steam Rankine \\
\hline
\end{tabular}

Source: Own elaboration based on ESTELA and PSA

\subsubsection{STE cost data}

Most of the STE plant project cost data including import shares and country of origin which was used in this study was provided by ESTELA. Table 3.2 shows the breakdown of the total investment cost of the plant, which amounts to 532,261,258 US\$. Labor cost shares estimates for the investment phase were obtained from a 115 MW STE tower plant with similar characteristics in Southern California (Turchi and Heath 2013). In Appendix 3.1 detailed information of costs breakdown is provided based on (Turchi and Heath 2013), differentiating between domestic and international shares according to ESTELA information and assigned to the corresponding economic sector based on United Nations database (United Nations 2016b). Additionally, transportation costs were included by considering transport margin costs information of economic sectors from 2011 MRIOT (WIOD 2016).

With regards to O\&M, total cost amounts to 10.22 million\$/year. Table 3.2 also shows annual cost breakdown provided by ESTELA. The "Spare parts and materials replacement" breakdown has been disaggregated following a detailed O\&M cost breakdown of the mentioned 115 MW plant (Turchi and Heath 2013). Additionally, 
water cost is assumed to be $0.7 \mathrm{US} \$ / \mathrm{m} 3$ (Fichtner et al. 2010), with a water consumption of 1 1/kWh year, according to ESTELA. Regular labor maintenance refers to daily maintenance (by local workers) whereas annual labor maintenance refers to manufacturers' maintenance of main components (turbine, receiver, etc.)

This O\&M cost data has been compared with other figures from the literature. The fixed costs data considered in this study (which include $50 \%$ of the "spare parts and materials replacement" costs, labor costs and insurances) amounts to $85 \$ / \mathrm{kW}$, which is similar to the value of $71 \$ / \mathrm{kW}$ reported by CSIRO (Common wealth Scientific and Industrial Australian Research Organization) (Hinkley et al. 2011). Similarly, the variable costs considered (wich includes $50 \%$ of the "spare parts and materials replacement" costs and water costs) amounts to $4.3 \$ \mathrm{MWh}$, which is similar to the 4\$/MWh reported by NREL (Turchi and Heath 2013).

Table 3.2 Investment and O\&M costs of the STE plant (in million US\$, "MUS\$”)

\begin{tabular}{|c|c|c|c|c|}
\hline $\begin{array}{l}\text { STE Investment cost } \\
\text { breakdown }\end{array}$ & $\begin{array}{l}\text { Investment } \\
\text { cost } \\
\text { breakdown } \\
\text { (MUS\$) }\end{array}$ & $\begin{array}{l}\text { Investment } \\
\text { labor } \\
\text { contribution } \\
\text { (in } \\
\text { percentage) }\end{array}$ & $\begin{array}{l}\text { STE O\&M cost } \\
\text { breakdown }\end{array}$ & $\begin{array}{l}\text { O\&M cost } \\
\text { breakdown } \\
\text { (MUS\$/yea } \\
\text { r) }\end{array}$ \\
\hline $\begin{array}{l}\text { Site } \\
\text { improvements }\end{array}$ & 15.5 & $45 \%$ & $\begin{array}{l}\text { Spare parts and materials } \\
\text { replacement }\end{array}$ & 2.87 \\
\hline Heliostat field & 141.8 & $11 \%$ & Solar field & 0.53 \\
\hline Tower costs & 20.1 & $46 \%$ & Receiver & 0.20 \\
\hline Receiver & 59.9 & $18 \%$ & Thermal energy storage & 0.16 \\
\hline $\begin{array}{l}\text { Thermal Energy } \\
\text { Storage }\end{array}$ & 28.8 & $9 \%$ & Power block & 1.98 \\
\hline Balance of plant & 36.8 & $39 \%$ & Water & 0.28 \\
\hline Power block & 115.0 & $37 \%$ & Insurances & 1.66 \\
\hline Tax & 17.9 & - & Annual labor maintenance & 2.65 \\
\hline $\begin{array}{l}\text { Engineering, } \\
\text { construction contracts } \\
\text { (EPC) and owner costs }\end{array}$ & 49.2 & - & Regular labor maintenance & 2.67 \\
\hline Land costs & 18.0 & - & & \\
\hline Contingency & 29.3 & - & & \\
\hline Total & 532.3 & $19 \%$ & Total & 10.22 \\
\hline
\end{tabular}


As for the financial assumptions, according to ESTELA, a project of this kind would have a debt of $70 \%$ of the investment cost to be returned in fifteen years. To determine the interest rate, $10^{\text {th }}$ years State Treasury Bonds (M10) average figures in Mexico have been considered, which amounts to 6\% in 2015 (Investing 2015). This figure should also account for the compensation of risks involved in the project, so an additional 5\% average rate is added from a Risk Free Premium basis, amounting to a total interest rate of $11 \%$. The addition of such risk percentage is related to the degree of maturity of the technology and the country risk profile, which can vary meaninfully the final interest rate applied (Foster Associates 2006; Nelson et al. 2012). Other interest rates used in similar studies for STE projects in developing countries range on 8-10\% interest rates in Chile (Starke et al. 2015; Telsnig and Ferrán-Díaz 2016); 11-14\% rates in India (Nelson et al. 2012) and even 18-20\% rates of renewable energy projects in Africa (Hamilton 2010). Moreover, the discount rate applied has been selected from a study of the World Bank in Mexico, assumed in 12\% (World Bank 2014).

Taking into account the above mentioned working assumptions, the total amount of O\&M costs during the life time of the plant amounts to 281.1 million\$, being 193.4 million\$ financial costs; 50.0 million\$ labor costs and 37.8 million\$ rest of non-labor costs.

Finally, the complete final demand vector associated to the STE investment and O\&M costs (without labor cost) is displayed in Table 3.3 
Table 3.3 Final demand vector for the investment and O\&M phases

\begin{tabular}{|c|c|c|c|}
\hline Country $^{\mathrm{a}}$ & Economic sector & $\begin{array}{l}\text { Investment } \\
\text { costs }(M \$)\end{array}$ & O\&M costs $(1000 \$)$ \\
\hline DEU & Chemicals & 16.9 & - \\
\hline DEU & Machinery, Nec & 17.6 & - \\
\hline DEU & Electrical and Optical Equipment & 11.1 & - \\
\hline DEU & Manufacturing, Nec; Recycling & - & 385.7 \\
\hline DEU & $\begin{array}{l}\text { Wholesale Trade and Commission } \\
\text { Trade }\end{array}$ & - & 2,913.6 \\
\hline DEU & Water Transport & 0.5 & 7.3 \\
\hline DEU & Other Supporting Transport Activities & - & 39.8 \\
\hline DEU & Post and Telecommunications & - & 193.9 \\
\hline DEU & $\begin{array}{l}\text { Renting of M\&Eq and Other Business } \\
\text { Activities }\end{array}$ & - & 348.9 \\
\hline MEX & Other Non-Metallic Mineral & 29.5 & - \\
\hline MEX & Basic Metals and Fabricated Metal & 75.6 & - \\
\hline MEX & Machinery, Nec & 12.0 & - \\
\hline MEX & Electrical and Optical Equipment & 19.0 & - \\
\hline MEX & Manufacturing, Nec; Recycling & - & $1,104.3$ \\
\hline MEX & Electricity, Gas and Water Supply & - & $2,156.3$ \\
\hline MEX & Construction & 21.6 & - \\
\hline MEX & $\begin{array}{l}\text { Wholesale Trade and Commission } \\
\text { Trade }\end{array}$ & - & $8,632.0$ \\
\hline MEX & Inland Transport & 2.2 & 162.1 \\
\hline MEX & Other Supporting Transport Activities & - & 15.8 \\
\hline MEX & Post and Telecommunications & - & 558.9 \\
\hline MEX & Financial Intermediation & 47.2 & $206,291.8$ \\
\hline MEX & Real Estate Activities & 18.0 & - \\
\hline MEX & $\begin{array}{l}\text { Renting of M\&Eq and Other Business } \\
\text { Activities }\end{array}$ & 49.3 & 860.8 \\
\hline NLD & Machinery, Nec & 7.0 & - \\
\hline NLD & Manufacturing, Nec; Recycling & - & 99.9 \\
\hline NLD & $\begin{array}{l}\text { Wholesale Trade and Commission } \\
\text { Trade }\end{array}$ & - & 756.6 \\
\hline NLD & Water transport & 0.1 & 2.3 \\
\hline NLD & Post and Telecommunications & - & 50.2 \\
\hline NLD & $\begin{array}{l}\text { Renting of M\&Eq and Other Business } \\
\text { Activities }\end{array}$ & - & 96.9 \\
\hline USA & Basic Metals and Fabricated Metal & 41.8 & - \\
\hline USA & Machinery, Nec & 11.9 & - \\
\hline USA & Electrical and Optical Equipment & 53.2 & - \\
\hline USA & Manufacturing, Nec; Recycling & - & 639.1 \\
\hline USA & Wholesale Trade, Commission Trade & - & $4,856.7$ \\
\hline USA & Inland Transport & 0.7 & 9.4 \\
\hline USA & Other Supporting Transport Activities & - & 6.4 \\
\hline USA & Post and Telecommunications & - & 320.7 \\
\hline \multirow[t]{2}{*}{ USA } & $\begin{array}{l}\text { Renting of M\&Eq and Other Business } \\
\text { Activities }\end{array}$ & - & 594.3 \\
\hline & TOTAL & 435.2 & $231,103.6$ \\
\hline
\end{tabular}

${ }^{\mathrm{a}} \mathrm{DEU}=$ Germany; MEX = Mexico; NLD = The Netherlands; USA = United States of America

Source: Own elaboration base on total investment and O\&M costs provided by ESTELA 


\subsubsection{WIOT and socioeconomic, environmental and social data sources}

The 2011 World Input Output Table (WIOT) has been used in this case study as it is the most recent one. Similarly, WIOD satellite accounts have been used to calculate the socioeconomic vectors and most of the environmental vectors when data was available. A detailed explanation of the assumptions and data used in each impact assessment is provided below.

The socioeconomic accounts from the WIOD database used in this case study are: gross value added (millions of national currency), number of persons engaged (thousands), total hours worked by persons engaged (millions) and compensation of employees (in millions of national currency) ${ }^{6}$. Complete data for 2011 was available for the accounts "Gross value added" and "Persons engaged". For the socioeconomic accounts "Hours engaged" and "Compensation of employees", the only complete data set for all countries was only available for 2009. The economic output used to calculate each vector corresponds to the same year as the satellite data used. In the case of the RoW region, data was only available for the assessment of production of goods and services and added value creation. For more information, WIOD documents can be consulted (Erumban et al. 2012a; Gouma et al. 2014).

The socioeconomic data used to calculate the induced effects is displayed in Table 3.4. The specific data requirements include total labor costs in Mexico and in the exporter countries, contribution of wages within such labor costs, the average household consumption distribution and the countries' average propensity to spend (OECD 2015; WIOD 2016).

Table 3.4 Assumptions for calculation of induced effects

\begin{tabular}{lrrcc}
\hline & \multicolumn{2}{c}{ Labor costs (million\$) } & $\begin{array}{l}\text { Compensation of employees, } \\
\text { \% from labor costs (WIOD) }\end{array}$ & $\begin{array}{l}\text { Households saving } \\
\text { rates (OECD) }\end{array}$ \\
\hline & Investment phase & O\&M phase & Country average & Country average \\
MEX & 49.8 & 34.8 & $91 \%$ & $8 \%$ \\
NLD & 0.8 & 0.8 & $86 \%$ & $5 \%$ \\
DEU & 6.5 & 6.7 & $86 \%$ & $10 \%$ \\
USA & 45.4 & 7.2 & $93 \%$ & $6 \%$ \\
\hline Total & 102.6 & 49.5 & - & - \\
\hline
\end{tabular}

Source: Own elaboration based on ESTELA cost data, WIOD and OECD

\footnotetext{
6 The currency exchange rates used for the conversion to US\$ can be consulted at http://www.ozforex.com.au/forex-tools/historical-rate-tools/yearly-average-rates; $\quad$ http://www.Xrates.com/historical/?from=EUR\&amount=1.00\&date $=2011-03-08$
} 
Environmental accounts from WIOD database used in this case study are energy use (in TJ) and emissions to air: $\mathrm{CO}_{2}$ (in $\mathrm{Gg}$ ) and $\mathrm{CH}_{4}, \mathrm{~N}_{2} \mathrm{O}, \mathrm{NO}_{\mathrm{X}}, \mathrm{SO}_{\mathrm{X}}, \mathrm{CO}, \mathrm{NMVOC}$ and $\mathrm{NH}_{3}$ (in tonnes). The most recent data available was from 2009, including the RoW region. For more information, WIOD documentation can be consulted (Genty et al. 2012). Emissions to air were used to estimate impacts on these three categories: climate change, acidification and formation of photochemical oxidants. The characterization factors used within each impact category is shown in Table 3.5.

Table 3.5 Environmental impact categories assessed and characterization factors considered

\begin{tabular}{|c|c|c|c|c|}
\hline $\begin{array}{l}\text { Impact } \\
\text { categories }\end{array}$ & Gases & $\begin{array}{l}\text { Characterization } \\
\text { factors }\end{array}$ & Sources & \\
\hline $\begin{array}{l}\text { Climate } \\
\text { change (gCO2 } \\
\text { eq) }\end{array}$ & $\begin{array}{l}\mathrm{gCO}_{2} \\
\mathrm{gCH}_{4} \\
\mathrm{gN}_{2} \mathrm{O}\end{array}$ & $\begin{array}{l}1 \\
28 \\
265\end{array}$ & IPCC 2013 & (IPCC 2013) \\
\hline $\begin{array}{l}\text { Acidification } \\
\text { (gSO2 eq) }\end{array}$ & $\begin{array}{l}\mathrm{gSO}_{\mathrm{x}} \\
\mathrm{gNO}_{\mathrm{x}} \\
\mathrm{gNH}_{3}\end{array}$ & $\begin{array}{l}1 \\
0.56 \\
2.45\end{array}$ & \multirow[b]{2}{*}{$\begin{array}{l}\text { ReCiPe } \\
\text { hierarchist } \\
\text { version, } \\
\text { midpoint } \\
\text { method }\end{array}$} & \multirow{2}{*}{$\begin{array}{l}\text { (Goedkoop et } \\
\text { al. 2013) }\end{array}$} \\
\hline $\begin{array}{l}\text { Formation of } \\
\text { photochemical } \\
\text { oxidants } \\
\text { (gNMVOC eq) }\end{array}$ & $\begin{array}{l}\mathrm{gNMVOC} \\
\mathrm{gNO}_{\mathrm{x}} \\
\mathrm{gCO} \\
\mathrm{gCH}_{4}\end{array}$ & $\begin{array}{l}1 \\
1 \\
0.0456 \\
0.0101\end{array}$ & & \\
\hline
\end{tabular}

Source: Own elaboration based on IPCC (2013) and Goedkoop et al. (2013)

Concerning water consumption, WIOD includes data available for 10 sectors $^{7}$ from 2009, including the RoW region. To complete sectorial water consumption, the global multiregional IO database EORA (EORA 2016), which has more detailed sectorial disaggregation in each country (Lenzen et al. 2013), has been consulted. EORA's sectors have been adapted to WIOD sectors, completing water consumption figures for ten more sectors ${ }^{8}$. Economic outputs used in the calculation of vectors correspond to WIOD data from 2009.

\footnotetext{
${ }^{7}$ WIOD sectors included: agriculture; foods and beverages; textiles; pulp and paper; chemicals; other non-metallic minerals; metals; electricity gas and water supply; education; health and social work.

${ }^{8}$ EORA sectors added are (data from 2000): mining; leather; wood; coke, refined petroleum and nuclear fuel; rubber and plastics; machinery; electrical and optical equipment; transport equipment; manufacturing, recycling; renting of machinery and other business activities. EORA data was not available for KOE, LUX and TWN.
} 
Similarly, biodiversity affection was estimated using the EORA database, by considering the account "Total threatened species", classified by phylum and classes, from the year 2000 (EORA 2016) according to the Threatened Species Red List of the International Union for Conservation of the Nature (IUCN) (IUCN 2015a). In order to construct the corresponding environmental vector, EORA data was clustered following the WIOD structure, and the economic output used was from 2000 WIOD data.

With regards to social risk values, no data was available for the following countries: United Kingdom, Ireland and Russia. Moreover, the social categories "Community Infrastructures" and "Governance" do not have sectorial disaggregation. Additionally, Appendix 3.2 contains information about some social risks from the SHDB (New Earth, 2013) which have been excluded in the assessment due to several reasons indicated in the mentioned appendix.

\subsection{Results and discussion}

Results for each sustainability pillar will be displayed in the three following subsections, distinguishing between direct, indirect and induced effects; national and international effects as well as investment and operation effects for each phase of the project. The last subsection includes the integrated assessment of all sustainability pillars through FISA charts.

\subsubsection{Socioeconomic impacts}

Table 3.6 shows direct, indirect, induced and total socioeconomic effects, the national share as well as the multiplier effect of the whole project.

Table 3.6 Direct, indirect and total socioeconomic effects and contribution of Mexico

\begin{tabular}{|c|c|c|c|c|c|c|c|c|c|c|}
\hline \multirow[t]{2}{*}{ Effects } & \multicolumn{2}{|c|}{$\begin{array}{c}\text { Production of } \\
\text { G\&S (M\$) }\end{array}$} & \multicolumn{2}{|c|}{$\begin{array}{l}\text { Added value } \\
\text { creation (M\$) }\end{array}$} & \multicolumn{2}{|c|}{$\begin{array}{c}\text { Employments } \\
\text { (Jobs) }\end{array}$} & \multicolumn{2}{|c|}{$\begin{array}{l}\text { Working hours } \\
\text { (1000WH) }\end{array}$} & \multicolumn{2}{|c|}{ Wages (M\$) } \\
\hline & Total & MEX & Total & MEX & Total & MEX & Total & MEX & Total & MEX \\
\hline Direct & 666 & $74 \%$ & 375 & $79 \%$ & 12719 & $90 \%$ & 17046 & $93 \%$ & 121 & $59 \%$ \\
\hline Indirect & 560 & $38 \%$ & 265 & $49 \%$ & 12602 & $50 \%$ & 16304 & $64 \%$ & 101 & $31 \%$ \\
\hline Induced & 132 & $55 \%$ & 79 & $57 \%$ & \multicolumn{2}{|c|}{ - } & \multicolumn{2}{|c|}{ - } & \multicolumn{2}{|c|}{-} \\
\hline Total & 1358 & $57 \%$ & 719 & $66 \%$ & 25321 & $70 \%$ & 33350 & $79 \%$ & 222 & $46 \%$ \\
\hline \multicolumn{5}{|c|}{ Multiplier effect } & & & & & \multicolumn{2}{|c|}{2.04} \\
\hline
\end{tabular}


Source: Own elaboration

Total production of goods and services (G\&S) amounts to 1,358 million dollars, from which $666 \mathrm{M} \$(49 \%)$ are direct effects from both the investment and O\&M project phases. The multiplier effect (ratio between total effects and direct effects) is 2.04, which indicates that for each dollar invested in the project, the global economy would be stimulated in 2.04 dollars. Additionally, $57 \%$ of the total production of G\&S is generated in Mexico (774 M\$), which implies that out of the 2.04 multiplier effect result, 1.16 dollars would be generated in Mexico and 0.88 abroad.

As for the added value (AV) creation result, it amounts to 719 million dollars, from which $52 \%$ are direct effects $(375 \mathrm{M} \$$ ). Moreover, from the total AV creation, $66 \%$ would be generated in Mexico (475 M\$). This national AV represents $60 \%$ of the resulted production of G\&S figure in Mexico (774 M\$). This can be compared to the $34 \%$ gross value added of the corresponding Mexican electricity sector in 2011 from WIOD socioeconomic accounts (WIOD 2016). From this comparison, it can be concluded that investments in this electricity generation technology would have a much greater contribution to the Gross Domestic Product (GDP) of Mexico than the average of the electricity sector.

Induced effects represents $10 \%(132 \mathrm{M} \$)$ of the total production of $\mathrm{G} \& \mathrm{~S}$; and $11 \%(79 \mathrm{M} \$)$ of the total added value created. Such induced effects are primarily produced in Mexico, being 55\% (73 M\$) of the production of G\&S induced effects and $57 \%$ (45 M\$) of the induced added value creation.

Total employment generated by the project amounts to 12,719 direct jobs and 12,603 indirectly created jobs, with a total of 25,321 employments. Direct jobs are primarily created in the national economy (90\%) while indirect ones have a larger offshored share (50\% national - 50\% international). The resulting employment factor is 7.9 employments/MW-year, being 127.2 direct employments per MW and 126.0 indirect employments per MW over the whole project life time. Other figures of STE plants from literature amount to 189 direct employments per MW and 133 indirect employments per MW (Caldés et al. 2009). Total working hours (WH) invested in the project amount to 33 million hours, from which $51 \%$ are related to direct effects and $79 \%$ take place in Mexico. 
Results on total wages generated amount to $222 \mathrm{M} \$$. Regarding the total WH figure (33 million $\mathrm{WH}$ ), the ratio of dollar per hour worked amounts to 7 dollars per hour worked. National wages represent $46 \%$ of total wages created (102 M\$). Taking into account the WH generated in Mexico (79\% contribution of total $\mathrm{WH})$, the ratio of dollar paid by worked hour in Mexico is $4 \$ / \mathrm{h}$. When calculating the same ratio for the international effects, it results in $17 \$ / \mathrm{h}$. This difference is even greater when looking at the direct effects, as Mexican direct wages are $5 \$ / \mathrm{h}$ while direct international jobs get paid at $40 \$ / \mathrm{h}$. This effect could be explained by the different qualification of the jobs and the difference in wages between Mexico and the rest of the concerned countries (mainly with United States of America, Netherland and Germany).

To analyze the results based on the different project phases, Table 3.7 displays socioeconomic impacts in the investment and operational phase distinguishing between national and international effects.

Table 3.7 Total socioeconomic impacts by project phases and contribution of Mexico

\begin{tabular}{lllllllllll}
\hline Effects & \multicolumn{2}{c}{$\begin{array}{c}\text { Production of } \\
\text { G\&S (M\$) }\end{array}$} & \multicolumn{2}{c}{$\begin{array}{c}\text { Added value } \\
\text { creation (M\$) }\end{array}$} & $\begin{array}{c}\text { Employments } \\
(\mathbf{J o b s})\end{array}$ & $\begin{array}{c}\text { Working hours } \\
(\mathbf{1 0 0 0 W H})\end{array}$ & Wages (M\$) \\
\hline \multirow{2}{*}{ INV } & Total & MEX & Total & MEX & Total & MEX & Total & MEX & Total & MEX \\
O\&M & 965 & $51 \%$ & 465 & $51 \%$ & 19648 & $65 \%$ & 23900 & $73 \%$ & 160 & $33 \%$ \\
Total & 1353 & $88 \%$ & 254 & $91 \%$ & 5673 & $88 \%$ & 94503 & $93 \%$ & 622 & $81 \%$ \\
& $135 \%$ & 719 & $66 \%$ & 25321 & $70 \%$ & 33350 & $79 \%$ & 222 & $46 \%$ \\
\hline
\end{tabular}

Source: Own elaboration

As shown in Table 3.6, the investment phase is responsible for the largest share of socio-economic effects: $71 \%$ of contribution in the production of G\&S (965 M\$); 65\% contribution in AV creation (465 $\mathrm{M} \$) ; 78 \%$ in employment creation (19648 employments), and $72 \%$ in $\mathrm{WH}$ and wages creation (24 million $\mathrm{WH}$ and $160 \mathrm{M} \$$ respectively). Total $\mathrm{WH}$ are paid at a rate of 7 dollars/h both in the investment phase and in the O\&M phase, while in Mexico the rates are $3 \$ / \mathrm{h}$ in the investment phase and 6 $\$ / \mathrm{h}$ during the O\&M phase.

In order to identify the most significant sectors stimulated by the project, Figure 3.3 displays the share of the total effects in those sectors with the highest contribution to the socioeconomic variables. 


\begin{tabular}{|c|c|c|c|c|c|}
\hline Country - Economic sector & G\&S(\%) & AV(\%) & Jobs (\%) & WH (\%) & Wages (\%) \\
\hline CHN Electrical and Optical Equipment & & & $3 \%$ & & \\
\hline DEU Chemicals and Chemical Products & $1 \%$ & & & & $3 \%$ \\
\hline DEU Machinery, Nec & $2 \%$ & $1 \%$ & & & $4 \%$ \\
\hline DEU Electrical and Optical Equipment & & & & & $2 \%$ \\
\hline MEX Mining and Quarrying & & $2 \%$ & & & \\
\hline MEX Other Non-Metallic Mineral & $3 \%$ & $3 \%$ & $4 \%$ & $4 \%$ & $3 \%$ \\
\hline MEX Basic Metals and Fabricated Metal & $8 \%$ & $5 \%$ & $8 \%$ & $6 \%$ & $4 \%$ \\
\hline MEX Machinery, Nec & & & $3 \%$ & $3 \%$ & $2 \%$ \\
\hline MEX Electrical and Optical Equipment & $2 \%$ & & $7 \%$ & $2 \%$ & \\
\hline MEX Construction & $2 \%$ & $2 \%$ & $6 \%$ & $7 \%$ & $3 \%$ \\
\hline MEX Sale, Maintenance and Repair of Motor Vehicles & & & $1 \%$ & $2 \%$ & \\
\hline MEX Wholesale Trade and Commission Trade & $2 \%$ & $2 \%$ & $1 \%$ & $2 \%$ & \\
\hline MEX Retail Trade, Except of Motor Vehicles & & & $2 \%$ & $4 \%$ & \\
\hline MEX Hotels and Restaurants & & & & $2 \%$ & \\
\hline MEX Inland Transport & & & & $2 \%$ & \\
\hline MEX Financial Intermediation & $23 \%$ & $31 \%$ & $12 \%$ & $16 \%$ & $34 \%$ \\
\hline MEX Real Estate Activities & $2 \%$ & $4 \%$ & & & \\
\hline MEX Renting of M\&Eq and Other Business Activities & $8 \%$ & $11 \%$ & $17 \%$ & $24 \%$ & $11 \%$ \\
\hline USA Basic Metals and Fabricated Metal & $6 \%$ & $4 \%$ & $3 \%$ & $2 \%$ & $8 \%$ \\
\hline USA Machinery, Nec & & & & & $2 \%$ \\
\hline USA Electrical and Optical Equipment & $5 \%$ & $6 \%$ & $1 \%$ & & $18 \%$ \\
\hline USA Wholesale Trade and Commission Trade & & $1 \%$ & & & $2 \%$ \\
\hline USA Renting of M\&Eq and Other Business Activities & $2 \%$ & $2 \%$ & & & \\
\hline Total sectors contribution & $65 \%$ & $74 \%$ & $69 \%$ & $74 \%$ & $94 \%$ \\
\hline
\end{tabular}

Figure 3.3 Top sectors contribution to socioeconomic impacts. Source: Own elaboration

The Mexican financial intermediation sector has the largest contribution in all categories except in employment creation, in which the renting of machinery and other business activities sector has the largest share. However, when it comes to wages, this sector has a similar contribution than some North American sectors, which reflects the wage differential between USA and Mexico. Other important sectors in all variables are the Mexican as well USA basic metals and fabricated metals sectors, the USA electrical and optical equipment sector, and the Mexican construction sector in terms of employments and working hours.

\subsubsection{Social impacts}

Table 3.8 shows the direct, indirect as well as total effects (measured by Project Social Index "PSI" values) across the five social analyzed categories, differentiating between national and international effects.

Table 3.8 Direct, indirect and total social effects and contribution in Mexico 


\begin{tabular}{|c|c|c|c|c|c|c|c|c|c|c|}
\hline \multirow[t]{2}{*}{ Effects } & \multicolumn{2}{|c|}{$\begin{array}{c}\text { Labor } \\
\text { rights } \\
\text { (1000PSI) }\end{array}$} & \multicolumn{2}{|c|}{$\begin{array}{l}\text { Health and } \\
\text { safety } \\
\text { (1000PSI) }\end{array}$} & \multicolumn{2}{|c|}{$\begin{array}{c}\text { Human } \\
\text { rights } \\
\text { (1000PSI) }\end{array}$} & \multicolumn{2}{|c|}{$\begin{array}{c}\text { Governance } \\
\text { (1000PSI) }\end{array}$} & \multicolumn{2}{|c|}{$\begin{array}{c}\text { Community } \\
\text { infrastructures } \\
\text { (1000PSI) }\end{array}$} \\
\hline & Total & MEX & Total & MEX & Total & MEX & Total & MEX & Total & MEX \\
\hline Direct & 37224 & $93 \%$ & 38565 & $94 \%$ & 29610 & $94 \%$ & 51501 & $96 \%$ & 26481 & $94 \%$ \\
\hline Indirect & 35446 & $65 \%$ & 40358 & $59 \%$ & 30391 & $60 \%$ & 44672 & $73 \%$ & 25890 & $63 \%$ \\
\hline Total & 72670 & $80 \%$ & 78923 & $76 \%$ & 60002 & $77 \%$ & 96174 & $86 \%$ & 52371 & $79 \%$ \\
\hline
\end{tabular}

Source: Source: Own elaboration

Direct and indirect social risks are originated in comparable sizes. Direct social risks appear primarily in Mexico (93-96\%) although some effects are also produced abroad. In the case of indirect social risks, these are produced in a range of 59-73\% in Mexico depending on the social category and in a $27-41 \%$ range abroad.

The contribution of each phase to social effects is displayed in Table 3.9.

Table 3.9 Social effects by phases (PSI values) and contribution of Mexico

\begin{tabular}{|c|c|c|c|c|c|c|c|c|c|c|}
\hline \multirow[t]{2}{*}{ Effects } & \multicolumn{2}{|c|}{$\begin{array}{c}\text { Labor } \\
\text { rights } \\
\text { (1000PSI) }\end{array}$} & \multicolumn{2}{|c|}{$\begin{array}{l}\text { Health and } \\
\text { safety } \\
\text { (1000PSI) }\end{array}$} & \multicolumn{2}{|c|}{$\begin{array}{c}\text { Human } \\
\text { rights } \\
\text { (1000PSI) }\end{array}$} & \multicolumn{2}{|c|}{$\begin{array}{c}\text { Governance } \\
\text { (1000PSI) }\end{array}$} & \multicolumn{2}{|c|}{$\begin{array}{c}\text { Community } \\
\text { infrastructures } \\
\text { (1000PSI) }\end{array}$} \\
\hline & Total & MEX & Total & MEX & Total & MEX & Total & MEX & Total & MEX \\
\hline INV & 51973 & $74 \%$ & 57072 & $70 \%$ & 43365 & $71 \%$ & 67315 & $81 \%$ & 37548 & $73 \%$ \\
\hline O\&M & 20697 & $93 \%$ & 21852 & $92 \%$ & 16637 & $92 \%$ & 28857 & $96 \%$ & 14823 & $93 \%$ \\
\hline Total & 72670 & $80 \%$ & 78923 & $76 \%$ & 60002 & $77 \%$ & 96174 & $86 \%$ & 52371 & $79 \%$ \\
\hline
\end{tabular}

Source: Own elaboration

Social risks during the investment phase amount to $70-72 \%$ of total risks while social risks in the O\&M phase represent a $28-30 \%$ share. Direct effects in Mexico during the investment phase show the highest values, both because of the large number of working hours in the stimulated sectors but also because of the existence of social risks.

Averaging all five social risk categories, Figure 3.4 shows the Project Social Hotspots (PSH), which correspond to the sectors with the highest PSI values, being sectors with a high amount of working hours from the project but also with high social risks values. These PSH have a 57\% contribution from total social effects. 


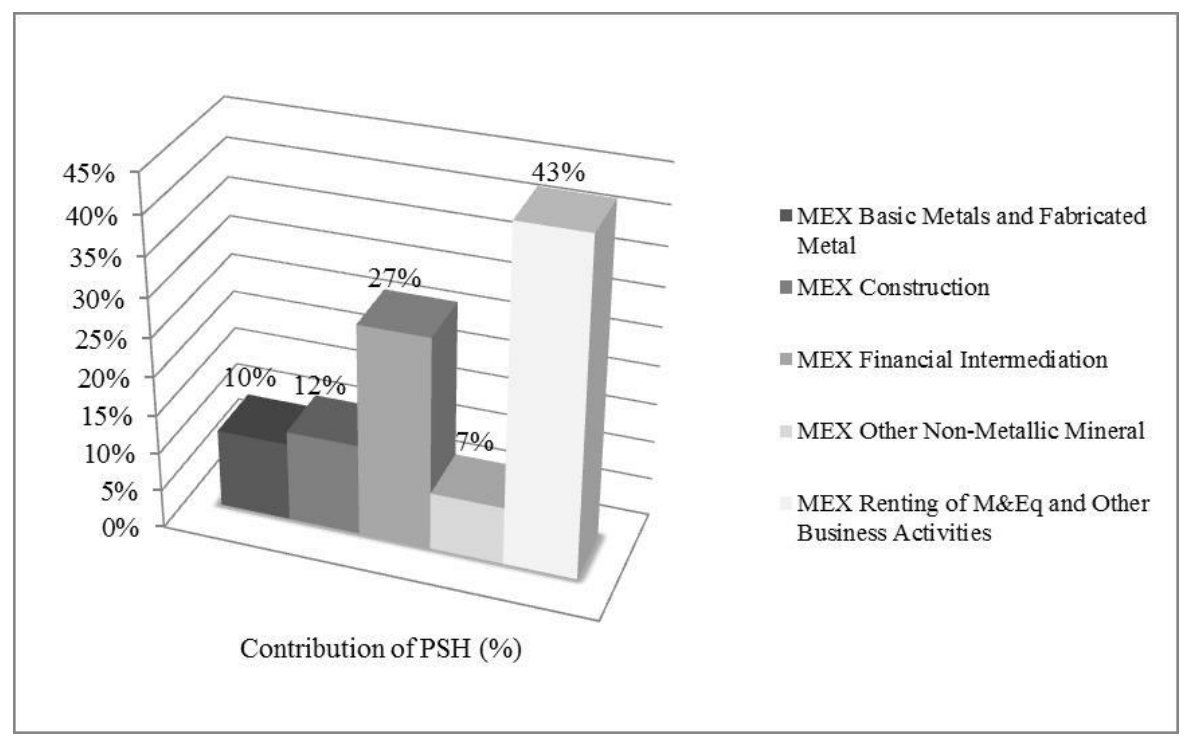

Figure 3.4 Project Social Hotspots (PSH). Source: Own elaboration

According to the results, the largest PSH appeared to be the "renting of machinery and other business activities" in Mexico, followed by the Mexican financial and construction sectors A more detailed analysis of the main social problems exiting in the largest PSH "renting of machinery and other business activities" is shown in Table 3.10.

Table 3.10 Social risks decomposition of the largest PSH "renting of machinery and other business activities" sector in Mexico

\begin{tabular}{|c|c|c|c|c|}
\hline \multirow{10}{*}{$\begin{array}{l}\text { MEX- } \\
\text { Renting } \\
\text { of } \\
\text { machiner } \\
\text { y and } \\
\text { other } \\
\text { business } \\
\text { activities }\end{array}$} & $\begin{array}{l}\text { Social } \\
\text { Impact } \\
\text { Category }\end{array}$ & $\begin{array}{l}\text { Average } \\
\text { risk } \\
\text { value }\end{array}$ & $\begin{array}{l}\text { Highest risk } \\
\text { values }(4=\text { very } \\
\text { high; } 3=\text { high }) \\
\end{array}$ & Highest social risk issues: description \\
\hline & Labor rights & 2.09 & 4 & Risk of Child Labor, Female (quantitat.) \\
\hline & \multirow{5}{*}{$\begin{array}{l}\text { Health and } \\
\text { safety }\end{array}$} & \multirow{5}{*}{2.17} & 3 & $\begin{array}{l}\text { Risk of loss of life years by } \\
\text { mesothelioma due to occupation }\end{array}$ \\
\hline & & & 3 & $\begin{array}{l}\text { Risk of loss of life years by asthma due } \\
\text { to airborne particulates in occupation }\end{array}$ \\
\hline & & & 3 & $\begin{array}{l}\text { Risk of loss of life years by chronic } \\
\text { obstructive pulmonary disease due to } \\
\text { airborne particulates in occupation }\end{array}$ \\
\hline & & & 3 & $\begin{array}{l}\text { Risk of loss of life years by silicosis } \\
\text { from airborne particulates in occupation }\end{array}$ \\
\hline & & & 3 & $\begin{array}{l}\text { Risk of loss of life years by airborne } \\
\text { particulates in occupation }\end{array}$ \\
\hline & Human rights & 1.63 & 4 & $\begin{array}{l}\text { High Conflict Zones: Characterization } \\
\text { of Heidelberg Barometer-indicator1 }\end{array}$ \\
\hline & Governance & 3.14 & 4 & $\begin{array}{l}\text { Legal System: Characterization of } \\
\text { Cingranelli-Richards Human Rights } \\
\text { Dataset - Independent Judiciary }\end{array}$ \\
\hline & $\begin{array}{l}\text { Community } \\
\text { infrastructure }\end{array}$ & 1.57 & 3 & $\begin{array}{l}\text { Access to Hospital Beds: Risk of too } \\
\text { few hospital beds to support population }\end{array}$ \\
\hline
\end{tabular}

Source: Own elaboration based on SHDB 
The existence of such social risks in Table 3.10 has been corroborated with various sources. According to a literature review on this subject, around 5\% and $24 \%$ of child population between 6-13 and 14-17 years respectively participated in labor works in 2011 in Mexico, being the legal working age fourteen (Understanding Children's Work 2012). In terms of risks of loss of life years, air particulates are reported to be one of the top ten risk causes of diseases and carcinogenicity in Mexico, with 461,500 years of healthy life lost associated to them (Centro Mario Molina 2003). Also, the Air Quality Index published by the Canadian International Development Research Centre (IDCR) and the World Health Organization (WHO) rank Mexico as one of the countries with the largest figures of air pollution and related health problems (Hibler 2003; Ostro 2004; Air Quality Index 2016). With regards to the human rights category, the high risk value according to the Heidelberg barometer is based on the severity of different conflicts within the country reported by several indicators (Heidelberg Institute for International Conflict Research 2015). Similarly, the high governance risk value results from the Cingranelli-Richars Human Rights Project, which collects different indicators associated to human rights and analyze their relationship with government related issues (Cingranelli and Richards 2010).

\subsubsection{Environmental impacts}

Table 3.11 shows direct, indirect as well as total environmental impacts and Mexican contribution

Table 3.11 Direct, indirect and total environmental effects per $\mathrm{kWh}$ inside and outside Mexico

\begin{tabular}{|c|c|c|c|c|c|c|c|c|c|c|c|c|}
\hline \multirow[t]{2}{*}{ Effect } & \multicolumn{2}{|c|}{$\begin{array}{c}\text { Energy } \\
\text { consumption } \\
(\mathrm{MJ} / \mathbf{k W h})\end{array}$} & \multicolumn{2}{|c|}{$\begin{array}{c}\text { Climate } \\
\text { change } \\
\left(\mathrm{gCO}_{2} \mathrm{eq} / \mathrm{kWh}\right)\end{array}$} & \multicolumn{2}{|c|}{$\begin{array}{l}\text { Acidification } \\
\left(\mathrm{gSO}_{2} \mathrm{eq} / \mathrm{kWh}\right)\end{array}$} & \multicolumn{3}{|c|}{$\begin{array}{c}\text { Photoch. oxidants } \\
\text { (gNMVOCeq/ } \\
\text { kWh) }\end{array}$} & $\begin{array}{c}\text { Water } \\
\text { consumption } \\
(\mathbf{l} / \mathbf{k W h})\end{array}$ & \multicolumn{2}{|r|}{$\begin{array}{l}\text { Threatened } \\
\text { Species } \\
(\% \text { affection })^{\mathrm{a}}\end{array}$} \\
\hline & Total & MEX & Total & MEX & Total & MEX & Total & MEX & Total & $\mathrm{ME}$ & Total & MEX \\
\hline & & & & & & & & & & $\mathrm{X}$ & & \\
\hline Direct & 0.13 & $77 \%$ & 8.8 & $85 \%$ & 0.02 & $99 \%$ & 0.05 & $80 \%$ & 0.5 & $60 \%$ & 0.0004 & $99 \%$ \\
\hline Indir. & 0.37 & $35 \%$ & 15.2 & $38 \%$ & 0.06 & $33 \%$ & 0.09 & $44 \%$ & 1.6 & $25 \%$ & 0.0013 & $54 \%$ \\
\hline Total & 0.50 & $46 \%$ & 24.0 & $55 \%$ & 0.08 & $50 \%$ & 0.14 & $57 \%$ & 2.1 & $33 \%$ & 0.0017 & $65 \%$ \\
\hline
\end{tabular}

${ }^{\mathrm{a}} \%$ of affection to threatened species figures on 2000 caused by total activities related with the project Source: Own elaboration 
To see the influence of the different phases in total effects, Table 3.12 shows national and international impacts in both phases, as well as some comparisons of STE impacts from literature.

Table 3.12 Total environmental impacts by project phases distinguishing national effects, and comparisons of impacts with literature

\begin{tabular}{|c|c|c|c|c|c|c|c|c|c|c|c|c|}
\hline \multirow[t]{2}{*}{ Effect } & \multicolumn{2}{|c|}{$\begin{array}{c}\text { Energy } \\
\text { consumption } \\
(\mathbf{M J} / \mathbf{k W h})\end{array}$} & \multicolumn{2}{|c|}{$\begin{array}{c}\text { Climate } \\
\text { change } \\
\left(\mathrm{gCO}_{2} \mathrm{eq} / \mathrm{kWh}\right)\end{array}$} & \multicolumn{2}{|c|}{$\begin{array}{c}\text { Acidification } \\
\left(\mathrm{gSO}_{2} \mathrm{eq} / \mathrm{kWh}\right)\end{array}$} & \multicolumn{3}{|c|}{$\begin{array}{c}\text { Photoch. oxidants } \\
\text { (gNMVOCeq/ } \\
\text { kWh) }\end{array}$} & $\begin{array}{c}\text { Water } \\
\text { consumption } \\
(\mathbf{l} / \mathbf{k W h})\end{array}$ & \multicolumn{2}{|c|}{$\begin{array}{c}\text { Threatened } \\
\text { Species (\% } \\
\text { affection) }\end{array}$} \\
\hline & Total & MEX & Total & MEX & Total & MEX & Total & MEX & Total & MEX & Total & MEX \\
\hline Inv & 0.4 & $43 \%$ & 20.8 & $52 \%$ & 0.07 & $43 \%$ & 0.12 & $50 \%$ & 1.8 & $33 \%$ & 0.0013 & $54 \%$ \\
\hline O\&M & 0.1 & $71 \%$ & 3.18 & $74 \%$ & 0.01 & $99 \%$ & 0.02 & $50 \%$ & 0.3 & $67 \%$ & 0.0004 & $99 \%$ \\
\hline Total & 0.50 & $46 \%$ & 24.0 & $55 \%$ & 0.08 & $50 \%$ & 0.14 & $57 \%$ & 2.1 & $33 \%$ & 0.0017 & $65 \%$ \\
\hline $\begin{array}{l}\text { Litera } \\
\text { ture }\end{array}$ & \multicolumn{2}{|c|}{$\begin{array}{c}0.14-0.36 ; 2.79 \\
\text { with gas abc }\end{array}$} & \multicolumn{2}{|c|}{$\begin{array}{l}\text { 12-24; } 70 \text { with } \\
\text { gas abcd }\end{array}$} & \multicolumn{2}{|c|}{$0.15^{b}$} & \multicolumn{2}{|c|}{$0.15^{b}$} & \multicolumn{2}{|c|}{$\begin{array}{l}0.1-3.3^{\mathrm{e}} ; 1.1- \\
4.7^{\mathrm{f}}\end{array}$} & \multicolumn{2}{|c|}{ - } \\
\hline
\end{tabular}

${ }^{\mathrm{a}}$ (Lechón et al. 2008); ${ }^{\mathrm{b}}$ (Corona et al. 2016a); ${ }^{\mathrm{c}}$ (De la Rúa Lope 2009); ${ }^{\mathrm{d}}$ (Burkhardt et al. 2012); ${ }^{\mathrm{e}}$ (Macknick et al. 2014); ${ }^{\mathrm{f}}$ (Burkhardt et al. 2011)

Source: Own elaboration

Total energy consumption amounts to $0.5 \mathrm{MJ} / \mathrm{kWh}$, which is in line with published values of similar power plants which range from 0.14 to $1.1 \mathrm{MJ} / \mathrm{kWh}$. Total global warming emissions amount to $24 \mathrm{~g} \mathrm{CO} 2 \mathrm{eq} / \mathrm{kWh}$. Harmonized Life Cycle Assessment estimations of global warming emissions of STE tower technology made by the National Renewable Energy Laboratory gave results of $22 \mathrm{~g} \mathrm{CO} 2 \mathrm{eq} / \mathrm{kWh}$ (Burkhardt et al. 2012), which is in close agreement with the results obtained here. Compared to Life Cycle Analysis estimations, MRIO results are expected to be larger as this methodology does not have to establish system limits in the analysis. Also, acidification and photochemical oxidants formation impacts are consistent with literature using environmentally extended MRIO analysis (Corona et al. 2016a). Total water consumption amounts to $2.1 \mathrm{l} / \mathrm{kWh}$, which is in close agreement with other published values for this technology (Macknick et al. 2014).

Regarding sectors contribution to environmental impacts, Figure 3.5 shows the share to the total effects of the sectors with the highest contribution to environmental variables. 


\begin{tabular}{|c|c|c|c|c|c|c|}
\hline Country - Economic sector & $\begin{array}{c}\text { Energy use } \\
(\%)\end{array}$ & $\begin{array}{c}\text { Climate } \\
\text { change (\%) }\end{array}$ & $\begin{array}{l}\text { Acidification } \\
(\%)\end{array}$ & $\begin{array}{l}\text { Photochemical } \\
\text { oxidants (\%) }\end{array}$ & $\begin{array}{c}\text { Water use } \\
(\%)\end{array}$ & $\begin{array}{l}\text { Threatened } \\
\text { species }(\%)\end{array}$ \\
\hline BEL Renting of M\&Eq and Other Business Activities & & & & & $5 \%$ & \\
\hline CHN Agriculture, Hunting, Forestry and Fishing & & & $3 \%$ & & $4 \%$ & \\
\hline CHN Electricity, Gas and Water Supply & & $4 \%$ & $7 \%$ & & & $14 \%$ \\
\hline DEU Chemicals and Chemical Products & $2 \%$ & & & $3 \%$ & & \\
\hline DEU Electricity, Gas and Water Supply & & & & & & $3 \%$ \\
\hline MEX Agriculture, Hunting, Forestry and Fishing & & & $3 \%$ & & $5 \%$ & $2 \%$ \\
\hline MEX Mining and Quarrying & & $2 \%$ & & & & \\
\hline MEX Coke, Refined Petroleum and Nuclear Fuel & $8 \%$ & & & $10 \%$ & & \\
\hline MEX Other Non-Metallic Mineral & $7 \%$ & $17 \%$ & $14 \%$ & $15 \%$ & & \\
\hline MEX Basic Metals and Fabricated Metal & $8 \%$ & $10 \%$ & $5 \%$ & $8 \%$ & $15 \%$ & \\
\hline MEX Electricity, Gas and Water Supply & $13 \%$ & $13 \%$ & $15 \%$ & $5 \%$ & $11 \%$ & $32 \%$ \\
\hline MEX Construction & & & & $3 \%$ & & $8 \%$ \\
\hline MEX Inland Transport & & & $2 \%$ & $3 \%$ & & \\
\hline MEX Financial Intermediation & & & & & & $2 \%$ \\
\hline MEX Renting of M\&Eq and Other Business Activities & & $2 \%$ & & & & $14 \%$ \\
\hline RUS Electricity, Gas and Water Supply & & & & & & $4 \%$ \\
\hline USA Agriculture, Hunting, Forestry and Fishing & & & & & $7 \%$ & \\
\hline USA Mining and Quarrying & & $2 \%$ & & & & \\
\hline USA Coke, Refined Petroleum and Nuclear Fuel & $9 \%$ & & & & & \\
\hline USA Basic Metals and Fabricated Metal & $5 \%$ & $6 \%$ & $5 \%$ & $5 \%$ & $11 \%$ & \\
\hline USA Electrical and Optical Equipment & & & & & $4 \%$ & \\
\hline USA Electricity, Gas and Water Supply & $4 \%$ & $4 \%$ & $4 \%$ & & & $6 \%$ \\
\hline RoW Agriculture, Hunting, Forestry and Fishing & & & & & $4 \%$ & \\
\hline RoW Coke, Refined Petroleum and Nuclear Fuel & $2 \%$ & & & $4 \%$ & & \\
\hline Total sectors contribution & $58 \%$ & $61 \%$ & $59 \%$ & $56 \%$ & $66 \%$ & $86 \%$ \\
\hline
\end{tabular}

Figure 3.5 Top sectors contribution to environmental impacts. Source: Own elaboration

The Mexican electricity sector has the largest contribution regarding energy consumption, whereas the nonmetallic mineral sector has largest shares in the climate change and creation of photochemical oxidants categories. These two sectors have similar contribution in the acidification category. In terms of water consumption, the metal sector in Mexico has the largest consumption, followed by the USA metal sector and the Mexican electricity sector. Also, the Mexican electricity sector mostly affects threatened species, followed by the same Chinese sector. This is both because the stimulation of these sectors but also because they have the largest figures of affection to threatened species. Figure 3.6 displays the number of threatened species in 2000 according to the IUCN Red List, classified under phylum and classes, affected by the top five riskiest stimulated sectors and countries (EORA 2016). 


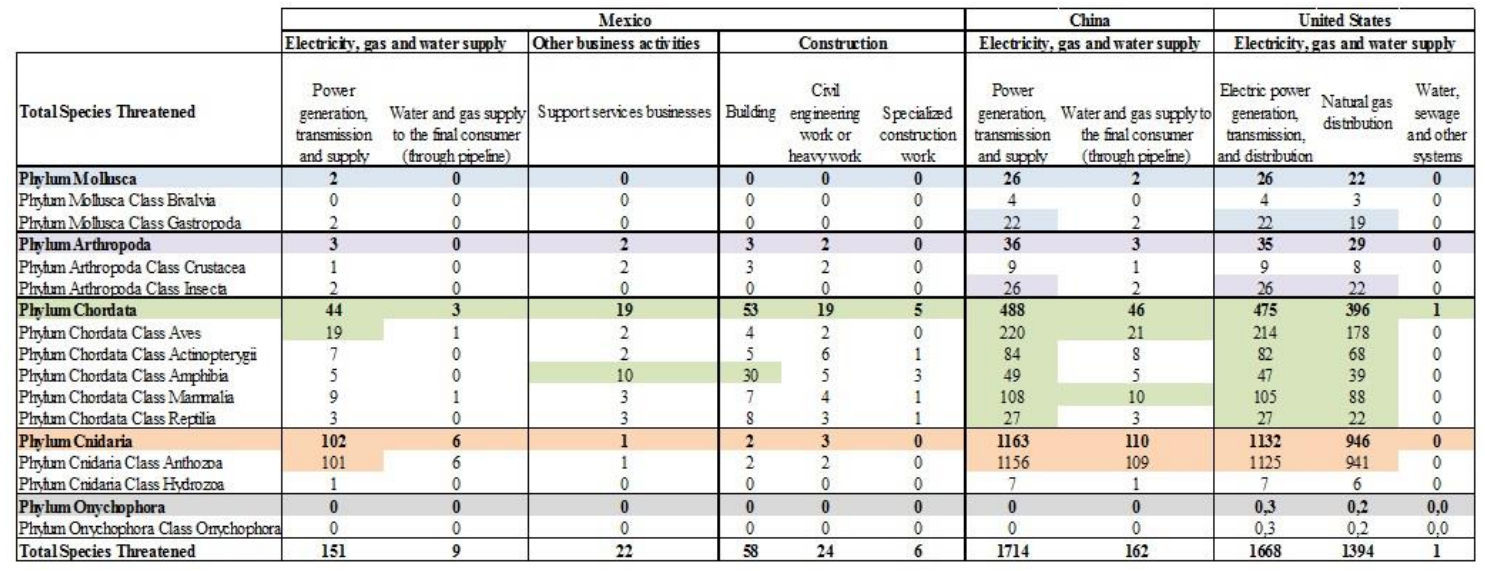

Figure 3.6 Number of threatened species in 2000 affected by the top five riskiest stimulated sectors. Source: Own elaboration based on EORA

The electricity sector has larger figures as it is responsible for most of the impacts affecting nature, as it can be seen in Figure 3.5. Also, the huge variety of activities involved leads to a wide diversity of impacts affecting species, for example destruction of habitats or direct deaths of individuals from collisions. Moreover, the above mentioned countries (Mexico, USA, China), have the highest records of threatened species worldwide. The IUCN Red List ranked Mexico, United States and China in the $5^{\text {th }}, 2^{\text {nd }}$ and $6^{\text {th }}$ position respectively with larger number of threatened species worldwide in 2015 (IUCN 2015b), being mammals one of the classes with larger figures of threatened species. Eco experts from the World Bank highlight Mexico as one of the countries with the largest figures of threatened mammal species, followed by others like China. However, these countries also show the largest figures of biodiversity wealth, being Mexico in the $4^{\text {th }}$ position of mammals' biodiversity worldwide rank ${ }^{9}$. In this sense, the activities from economic sectors within these countries have higher risks to affect biodiversity negatively. In this sense, Myers et al (2000) identified 25 hotspots of biodiversity, being the above countries three wide hotspots: the West coast of United States, South-Central China and the whole country of Mexico (Myers et al. 2000).

3.4.4. Sustainability impacts through FISA charts

\footnotetext{
${ }^{9}$ http://www.businessinsider.com/mexico-has-most-threatened-species-2015-4
} 
Besides considering the three types of effects independently, FISA charts presented in this section display the three sustainability pillars results in a simultaneous way. In particular, the FISA charts show the contribution of each impact in the specific analyzed effects (e.g.: direct and indirect effects) over total effects. The results are presented in two figures: Figure 3.7 shows direct/indirect and national/international effects over the total effects; and Figure 3.8 displays national/international effects in the investment and O\&M phases over total effects. For more details of the underlying numbers represented in FISA charts, the corresponding sustainability section above can be consulted.

Figure 3.7 displays the share of direct and indirect effects occurring both in Mexico as well as outside Mexico.

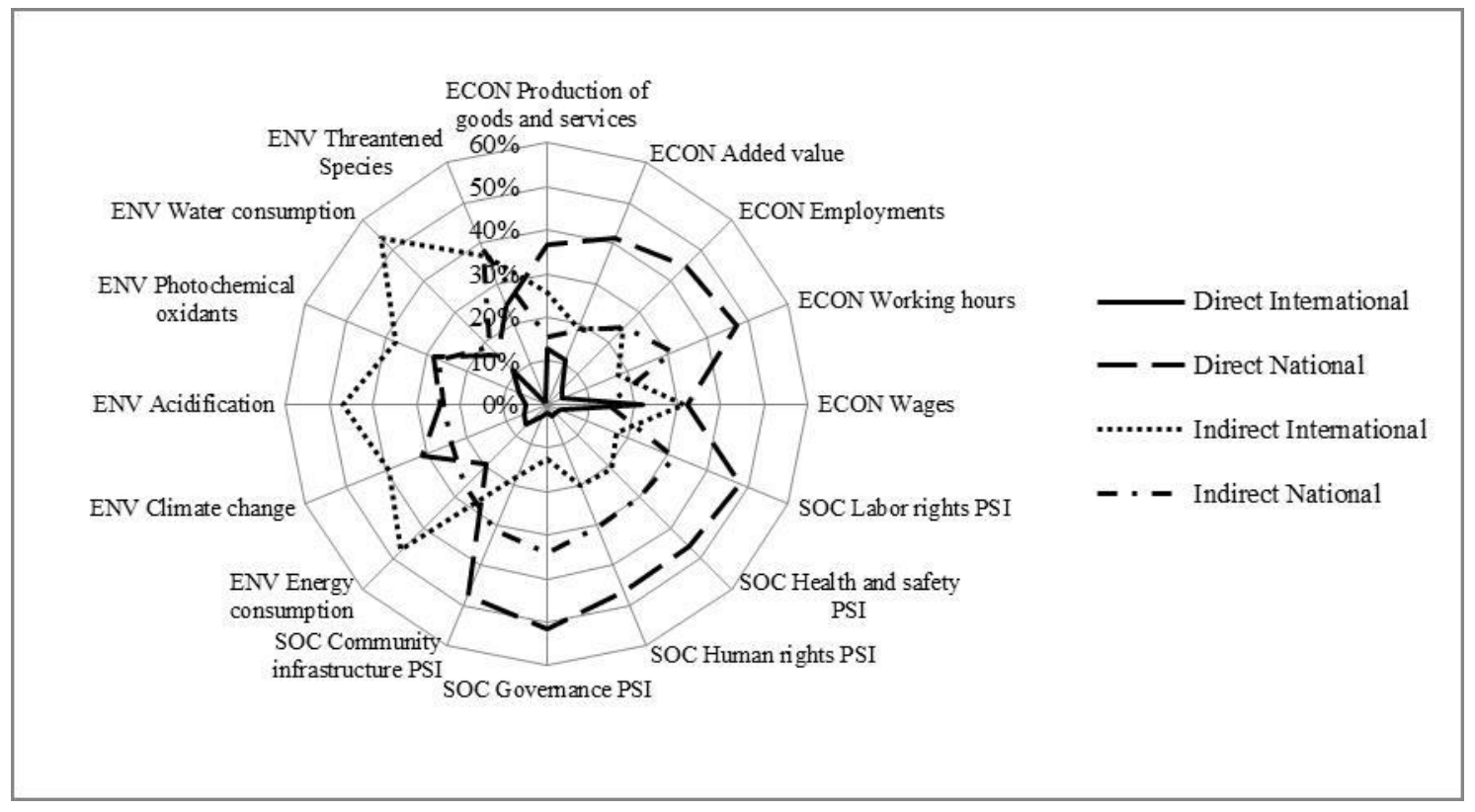

Figure 3.7 Proportion of direct and indirect effects of sustainability impacts occurring in Mexico and outside Mexico. Source: Own elaboration

As shown in Figure 3.7, socioeconomic and social effects mainly occur as a result of the direct effects in Mexico, with the exception of wages, which are similar to the international scope. Environmental effects are mostly produced internationally as result of indirect effects, except for the affection to threatened species, which indirect effects in Mexico are of similar magnitude. 
In order to assess the relevance of each phase within total effects, Figure 3.8 displays national and international sustainability effects distinguishing the different phases of the project.

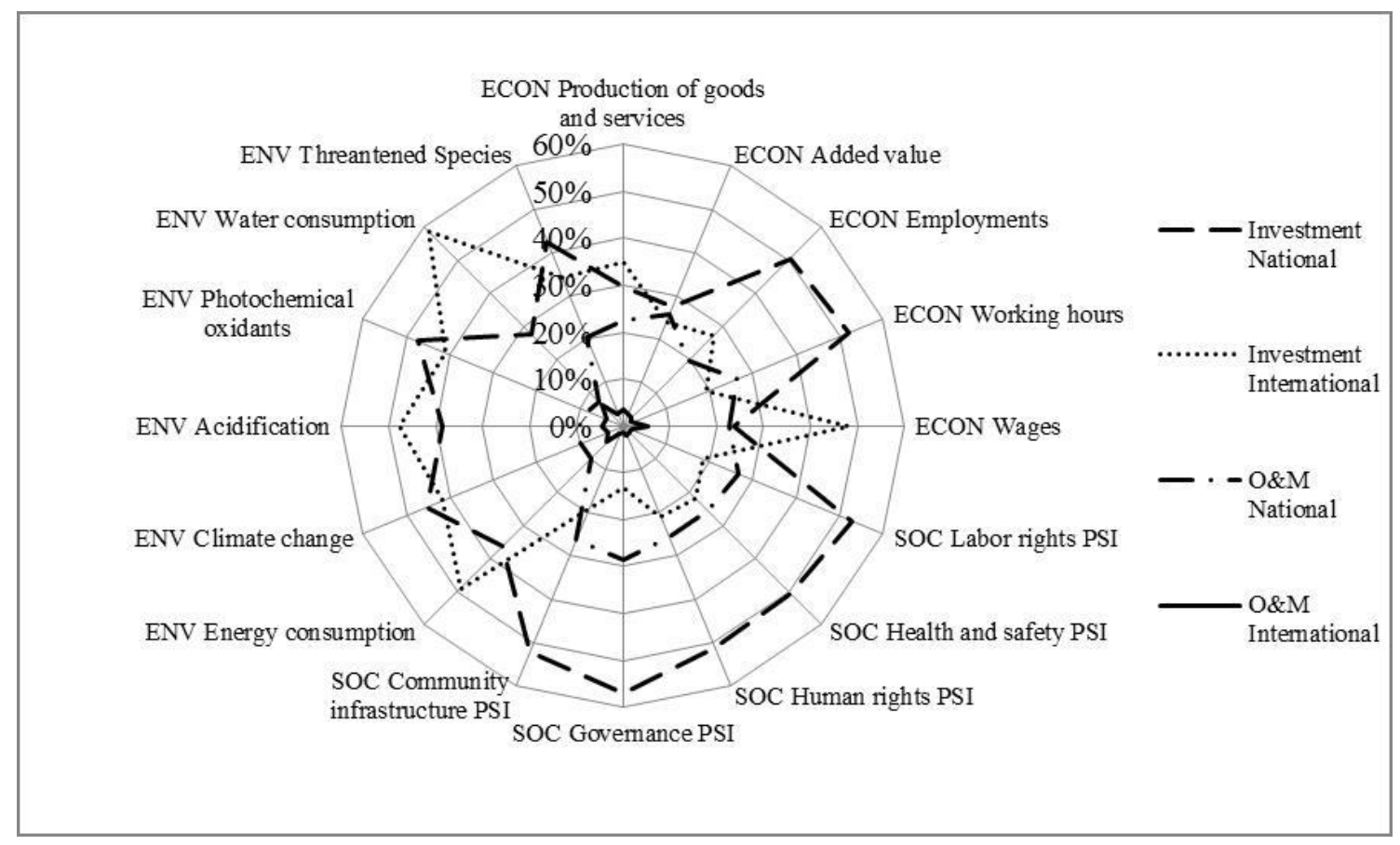

Figure 3.8 Proportion of national and international effects by phases of the project.

Source: Own elaboration

As shown in Figure 3.8, the investment phase is responsible for most of the impacts in each sustainability pillar. While socioeconomic indicators show similar figures in this phase regarding production of goods and services and added value creation for both national and international scopes; employments, working hours and wages have substantial differences, being the number of jobs and working hours larger in Mexico while wages are higher internationally. Social PSI values are also larger in this phase in Mexico, whereas environmental impacts have fewer differences inside and outside Mexico in all environmental categories except on water consumption, which impacts are higher in an international scope.

Summarizing, thanks to the graphical display of the results, the FISA charts are useful to quickly identify the sustainability hotspots of the project. From the analyzed case study, FISA results show large socioeconomic benefits located in Mexico during the investment phase from direct effects. However, it also results in poor working conditions in terms of high working hours and low wages. Moreover, the associated 
potential social risks within sectors from such direct effects should be taken into account. Additionally, remarkable socioeconomic benefits but also harmful environmental impacts and social risks have been identified outside Mexico as a result of international trade during the investment phase. These results indicate the need to monitor and, to the extent possible, try to reduce such harmful effects along the whole supply chain, both inside but also outside Mexican borders.

\subsection{Conclusions}

When assessing an investment project, it is important to take into account not only cost figures but also its impacts in the three sustainability pillars. In this work, a comprehensive sustainability assessment of a Solar Thermal Electricity plant in Mexico has been conducted using the Framework for Integrated Sustainability Assessment (FISA). The application of this framework has identified the sustainability hotspots from direct and indirect effects occurring inside and outside Mexico during the project phases.

Results obtained from the assessment indicate that, within the socioeconomic pillar, the largest effects would occur as a result of direct effects in Mexico, especially during the investment phase, such as employment creation. However, wage figures are larger abroad, mainly resulting from indirect effects. These low national wage figures and the large working hours results in Mexico may reflect poor national labor conditions. Additionally, some social risks should be taken into account and monitored during the investment phase as pointed out from the results of direct effects in Mexico. Finally, the most relevant environmental impacts are caused by indirect effects outside Mexican borders during the investment phase, mostly from the investment phase activities.

In this sense, the results from this study indicate that the deployment of the STE plant could be beneficial for the Mexican economy as a way to stimulate its economy and create employment. However, poor labor conditions and some social risks existing in the stimulated sectors should be monitored. Additionally, in order to minimize the associated environmental burden in Mexico, given the energy intensive activities involved along the supply chain, it would be recommended to progressively decarbonize the Mexican energy mix. 
In summary, FISA results in this work could help decision makers consider the sustainability impacts along the supply chain of the deployment of a STE plant in Mexico. The validity of the FISA framework has been contrasted in this work by comparing the results with similar studies. However, when interpreting the results, it is important to be aware of the limitations of the FISA framework and its implications for the results of the case study. One of the main methodological limitations is related to the sectorial aggregation involved in the Input Output assessment, which assumes the same nature of socioeconomic and environmental impacts in a given sector. With the incorporation of social risks proposed in the FISA framework, such limitation also applies to the social dimension as social risks are assumed to be homogeneous within all activities aggregated in the same sector. Other limitations are related to the limited update of the FISA supporting databases, such as the Multiregional Input Output Tables, the socioeconomic and environmental accounts and social risk data within the Social Hotspot Database (SHDB). Additionally, the SHDB lacks some social risk data for a few countries and sectors, and it is not exempt from uncertainties related to the social data collection or the conversion of qualitative information into quantitative figures. Furthermore, given the limitations associated to the influence of the data and working assumptions to the results, a sensitivity analysis on key selected variables is envisaged in a future research, such as variations in the local content share of the STE components. Finally, other future lines of research will focus on the comparison of the sustainability impacts of different energy projects in order to help decision makers towards the optimal energy investment choice from a sustainability point of view.

\section{Acknowledgments}

We would like to thank all experts consulted in this case study for their support and for the information provided. Particularly, the authors would like to thank ESTELA and the Plataforma Solar de Almería. The authors would also like to express their gratitude to the reviewers for their valuable comments. 


\title{
4. Sustainability impact assessment of alternative Solar Thermal Electricity and Natural Gas Combined Cycle electricity production in Mexico ${ }^{10}$
}

\begin{abstract}
The aim of this paper is to conduct a comprehensive sustainability assessment to compare impacts of two electricity generation alternatives in Mexico using FISA (Framework for Integrated Sustainability Assessment). The framework has been used in this work to estimate and compare the socioeconomic, environmental and social impacts of electricity production from alternative Solar Thermal Electricity (STE) and Natural Gas Combined Cycle (NGCC) technologies in Mexico. Results show that the associated socioeconomic impacts and social risks impacts of NGCC and STE are of the same magnitude, but STE creates a higher added value, generate better quality employment and social risks involved in sectors are easier to identify. As for the environmental effects, NGCC impacts are remarkably larger than STE, mainly as a result of natural gas consumption. Regarding the location of the effects, despite the embedded international trade and imports, most impacts take place in Mexico. The results from the application of FISA could not only help decision makers in their energy related investment decisions but also guide them towards applying the necessary measures to minimize the negative impacts on the social, economic and environmental sustainability pillars while fostering the positive ones.
\end{abstract}

Key words: Multiregional Input Output, integrated sustainability assessment, Solar Thermal Electricity, impact comparison, Mexico, decision making support.

\footnotetext{
${ }^{10}$ Under Review in Journal of Energy for Sustainable Development. Co-authored with Natalia Caldés, Cristina de la Rúa and Yolanda Lechón (Energy Systems Analysis Unit, Energy Department, Technical, Environmental and Energy Research Centre (CIEMAT)). Authors would like to thanks all experts consulted in this case study, for their support and data provided, especially to the European Solar Thermal Electricity Association (ESTELA), the Plataforma Solar de Almería (PSA) and Dr. Antonio Rodríguez from the Universidad Autónoma del Estado de Morelos (UAEM)
} 


\subsection{Introduction}

Traditionally, when deciding between alternative investment projects, most decision makers focused on their techno-economic aspects (their technical viability as well as their investment and operation \& maintenance costs). However, other criteria have started to be taken into account such as the potential environmental impacts and related consequences for ecosystems as well as social impacts such as compliance to good labor conditions or healthy environment (Santoyo-castelazo and Azapagic 2014b; Cartelle Barros et al. 2015). The consideration and integration of the three types of sustainability impacts -economic, social and environmental- is achieved by using the so-called Integrated Assessments (IA), but there is not a universal meaning or method for its attainment (Hacking and Guthrie 2008). According to Lee (2002), one possible way to conduct an IA is connecting the different types of impacts (e.g. physical and socioeconomic variables), and other way consists on the integration of such assessments into the decision making processes (Lee 2002).

The Framework for Integrated Sustainability Assessment (FISA) integrates the three sustainability pillars by relating the economic stimulation associated to specific investment projects with environmental, socioeconomic and social data in order to assess its different impacts; distinguishing the direct, indirect as well as domestic and international effects (Rodríguez-Serrano et al. 2016b). The simultaneous consideration of the three types of impacts thorough FISA outputs could help decision makers in choosing the most sustainable investment project as well as to identify the measures needed to minimize the harmful effects while fostering the positive ones.

Decision makers in the energy sector could potentially benefit from such assessment results because they often have to choose between different electricity generations technologies. This is particularly relevant in developing countries where energy demand is rapidly growing hand in hand with their economic growth. In this sense, decision makers must often decide between conventional fossil fuel technologies and renewable technologies. Despite electricity generation from fossil fuels is usually cheaper than from renewable resources, fossil fuel based economies face problems of various nature (such as environmental impacts, energy security, unhealthy local air etc.). 
Mexico is a country whose economy largely relies on fossil fuels. In 2013, 32\% of total government revenues came from the oil industry (U.S. Energy Information Agency 2014). Moreover, due to its fossil-fuel based economy, the total $\mathrm{CO}_{2}$ eq emissions in 2015 amounted to 800 million metric tons (Mt) (SEMARNAT 2016). However, since 2005, this trend is decreasing due to fuel depletion and production decline of large offshore fields (Instituto Nacional de Estadística y Geografía 2016). Mexico is also vulnerable due to fossil fuel imports, as it is a net importer of refined petroleum products, specially gasoline diesel and liquefied petroleum gases (U.S. Energy Information Agency 2014).

Other key component of Mexico's economy is natural gas. In 2014, domestic demand of natural gas amounted to $42.8 \%$ from total primary fuels. Additionally, imported natural gas represented $30 \%$ of national production in 2014. Most of imports come from United States (around 70\%) and the rest correspond to Liquefied Natural Gas mainly from Peru, Trinidad and Tobago, Nigeria, Indonesia and Qatar (SENER 2015b). The economic sector with the largest demand of natural gas is the electricity sector, with $41.6 \%$ of total natural gas demanded in 2014 (SENER 2015b). Electricity production from natural gas supposed $57 \%$ of the mix in 2014, figure which has increased in the last years (43\% in 2004), mainly due to decrease from fuel oil (SENER 2015c).

In order to decrease its dependence from fossil fuels and increase renewable energies contribution, Mexican government enacted the Climate Change law in 2012, which set the target of $35 \%$ of the electricity generation from clean energies -including nuclear- by 2024 (Secretaría General 2012). Additionally, an energy reform was established in 2013 whose main objective was to open the market to private companies in order to diversify the energy sector and decrease the high electricity tariffs (SENER 2015c). Nowadays, renewables represent around 15\% of total electricity installed capacity (SENER 2015c). This contribution is expected to increase, covering $45.7 \%$ with conventional technologies (from which $96.4 \%$ combined cycle) and 54.3\% with renewables technologies (from which 37\% wind) from 2015 to 2019 (SENER 2015a). If the national energy targets are achieved, around $700 \mathrm{MtCO}_{2} \mathrm{eq}$ would be avoided by 2030 compared to a business as usual scenario (Cabal et al. 2015). 
With more than $2,500 \mathrm{kWh} / \mathrm{m}^{2}$ of Direct Normal Irradiation (DNI), Solar Thermal Electricity (STE) has a large potential in Mexico. However, its higher cost compared to other alternative technologies together with the still undeveloped market are important hurdles for new investments in this technology. Nevertheless, one of the advantages of STE compared to other renewables is its dispatchability, allowing the supply of electricity on peak demands. Moreover, STE currently has a worldwide installed capacity of $5 \mathrm{GW}$ (ESTELA 2016) which is far from the deployment level of other renewable technologies such as wind $(400 \mathrm{GW})$ and photovoltaics $(200 \mathrm{GW})$. Thus, over the next few years, STE is expected to experience important cost reductions when approaching power markets similar to those technologies. As by 2030, it is expected that STE could supply $5 \%$ of the world power demand and $12 \%$ by 2050 (SolarPaces et al. 2016).

In this context, the work presented here aims at conducting a sustainability impact assessment of Solar Thermal Electricity (STE) and Natural Gas Combined Cycle (NGCC) for electricity production during the investment and operation life cycle stages and comparing its results using FISA. In the next section, FISA methodological steps are described including the integration of the underlying Multiregional Input Output (MRIO) methodology and the social risk database "Social Hotspot Database". Next, data and assumption of the NGCC and STE technologies are described. Finally, the results from the two technologies will be compared and the main conclusions will be presented.

\subsection{Methodology}

\subsubsection{Multiregional Input Output (MRIO)}

Input-Output (IO) methodology allows analyzing trade relationships of economic sectors through the use of Input Output Tables (IOTs) (Leontief 1936). IOTs describe, in columns, the monetary value of products that a sector needs from the rest of sectors to obtain its total production (inputs); whereas rows show the distribution in monetary values of the production of a sector over the rest of sectors (outputs) (Wiedmann et al. 2007). When considering various regions or countries, it is possible to estimate the economic stimulation produced in other regions due to a change in the demand of goods and services $(G \& S)$ of one region by the use of Multiregional Input Output Tables 
(MRIOTs) (Ten Raa 2006). The monetary value of products that one sector needs from the rest of sectors to obtain one monetary unit of production is represented by technical coefficients, which are gathered within the technical coefficient matrix or $A$ matrix (Miller and Blair 2009).

The total G\&S produced by a specific demand can be estimated as shown in Eq. (1).

$$
\mathrm{x}=(\mathrm{I}-\mathrm{A})^{-1} \cdot \mathrm{y}
$$

where $\mathrm{x}$ is the total production of goods and services (total effects), $A$ is the technical coefficient matrix, $(\mathrm{I}-\mathrm{A})^{-1}$ is the inverse of Leontief which represents direct and indirect effects and $y$ is the required demand.

Estimation of total effects include direct and indirect effects, being direct effects related to the demand requirements for the project and indirect effects those inputs necessary to satisfy the direct demand. The multiplier effect gives information about the total stimulation produced from direct effects (Caldés et al. 2009).

IO analysis allows estimating other impacts (e.g. working hours, $\mathrm{CO}_{2}$ emissions...), by extending the methodology with vectors describing specific impacts per monetary unit produced in each economic sector. These impacts can be calculated by Eq. (2).

$$
\mathrm{z}_{\mathrm{t}}=\mathrm{z}_{\mathrm{i}} \cdot(\mathrm{I}-\mathrm{A})^{-1} \cdot \mathrm{y}
$$

where $\mathrm{z}_{\mathrm{t}}$ is the total socioeconomic or environmental effects and $\mathrm{z}_{\mathrm{i}}$ is the environmental or socioeconomic vector

MRIO analysis in this work is based on the World Input Output Database (WIOD) (Timmer et al. 2015), which is the result of a European Commission funded project within the $7^{\text {th }}$ Framework Programme (WIOD 2016). It contains time-series of world input output tables from 1995 to 2011, including 40 countries with thirty five economic sectors plus a Rest of the World (RoW) region. It also contains time-series of socioeconomic and environmental data (e.g. employment, working hours, energy use, air emissions or water consumption). One of the advantages of this database is that it is publicly accessible and its IOTs are based on supply-uses tables from national statistics 
that are later integrated with bilateral trade statistics, reaching more accuracy between resulting information and national statistical (Jones et al. 2014). Nevertheless, it has fewer sectorial disaggregation and less country data than other exiting databases, especially from the aggregation of countries within the RoW region (Tukker and Dietzenbacher 2013).

\subsubsection{Adding the social pillar: Framework for Integrated Sustainability Assessment (FISA)}

To achieve the integrated sustainability assessment previously described, the social pillar is covered by adding a social risk database named Social Hotspot Database (SHDB). Developed by New Earth in 2011, it contains information of an ample variety of social indicators classified in 22 social themes and five impact categories (SHDB 2016). Social themes and impact categories can be consulted in Supplementary Materials in Appendix 4.1.

The social indicators values are obtained from numerous social databases such as International Labor Organization (ILO) or World Bank (WB). These indicators are transformed into social risk values, which represent the degree of different social threats occurring in the various economic sectors (Benoit Norris et al. 2012). The transformation process is mainly based on the distribution of data (e.g. quartiles) (Franze 2013), and the social risks obtained are classified into a 1 to 4 quantitative scale, in which 1 represents low risks and 4 represents very high risk. Detailed information about social risks and the underlying data can be found in (New Earth 2013a).

The methodological link between the SHDB and the MRIO is possible by relating sectorial social risks values according to WIOD classification with MRIO working hours resulted from a project. Such linkage is done in the so called Project Social Index (PSI) (Rodríguez-Serrano et al. 2016b). In this sense, an economic sector with a high PSI value indicates that it has been highly stimulated by the analyzed project (in terms of working hours) and that this sector has some sort of social risks. The highest PSI values are used to identify the Project Social Hotspots (PSH), which alert about the potential largest social risks associated to the studied project. Based on the PSH results, a more detailed analysis of the corresponding social risks within sectors 
should be performed to identify potential measures needed to minimize such problems. The FISA framework and methodological steps of Rodríguez-Serrano et al (RodríguezSerrano et al. 2016b) is displayed in Supplementary Materials in Appendix 4.2.

Once the three types of sustainability impacts have been estimated, they can be graphically illustrated through the FISA charts in order to show the complete sustainability assessment. FISA charts allow for the simultaneous comparison of the different types of impacts of two or more alternative projects. Such visual results may support decision makers in the selection of the best alternative taking into account the assessed impacts covering the three sustainability pillars.

\subsection{Application of FISA: impact assessment comparison of STE and NGCC for electricity production in Mexico}

In this section, a comparison of the impacts among the three sustainability pillars within the investment and O\&M phases of STE and NGCC technologies for the production of 11,871.4 GWh electricity has been carried out. The hypothetic case study location is set at Sonora State, in Mexico, with a considered Direct Normal Irradiation of 7.0 $\mathrm{kWh} / \mathrm{m}^{2} /$ day.

\subsubsection{STE and NGCC costs}

STE investment cost provided by industry experts amounts to 45 US\$ per MWh (Rodríguez-Serrano et al. 2017). For the NGCC, according to the Federal Electricity Commission (CFE), the investment costs of a reference Mexican NGCC plant amounts to $14 \mathrm{US} \$$ /MWh (CFE 2012). Investment cost breakdown for both technologies can be consulted in Supplementary Materials in Appendix 4.3. Labor shares has been applied from (Turchi and Heath 2013) in the case of STE (Rodríguez-Serrano et al. 2017) and from (Battelle 1982) in the case of NGCC. Import shares and country of origin were provided by STE industry experts and assumed the same as for NGCC when sharing components (e.g. steam turbine, generator, pipelines, etc.). Gas turbine is imported from the USA (Office of Technology Evaluation 2015). The allocation of components costs to economic sectors is done according to United Nations Statistic Division (United Nations 2016b). 
For O\&M costs, STE provided by Industry experts amounts to 7.4 US\$ per MWh (without fuel and financial costs) (Rodríguez-Serrano et al. 2017). For NGCC O\&M costs, according to the Mexican Electricity Research Institute (IEE), O\&M costs in Mexico vary from 4.5 to $5 \mathrm{US} \$ / \mathrm{MWh}$ (without fuel and financial costs). In this sense, a reference value of $4.83 \mathrm{US} \$ / \mathrm{MWh}$ has been selected from the Mexican CFE (CFE 2012). O\&M cost breakdown for both technologies can be consulted in Supplementary Materials in Appendix 4.4. Spare parts and replacement cost breakdown has been obtained from (Turchi and Heath 2013) for STE and from (NREL 2008) for NGCC; and assigned to corresponding countries' manufacturers of components. Water consumption for STE provided by industry experts amounts to $11 / \mathrm{kWh}$ and similar figure is assumed for NGCC (1.14 1/kWh) (Macknick et al. 2014), with a water cost of $0.7 \mathrm{US} \$ / \mathrm{m}^{3}$ (Fichtner et al. 2010). In terms of labor costs, regular labor maintenance refers to daily maintenance by local workers; whereas annual labor maintenance refers to once-a-year maintenance of principal components (steam turbine, gas turbine, steam generator, receiver, etc.) by manufacturers of components.

As for the financial cost, according to industry experts, STE projects have a 70\% debt of the investment cost to be returned in fifteen years, whereas NGCC projects have a 50\% debt (NREL 2008). The interest rate has been determined taking into consideration the 10th years State Treasury Bonds (M10) average figures in Mexico which amounts to 6\% in 2015 (Investing 2015). This figure does not include compensation of risks involved in projects, so an additional 5\% is considered for high risks STE (Foster Associates 2006) and 1\% for low risks NGCC (NREL 2008). Total interest rates amount to $11 \%$ for STE (Rodríguez-Serrano et al. 2017) and 7\% for NGCC, and the resulting financial costs amounts to 16.29 US\$/MWh for STE and 2.66 US\$/MWh for NGCC. The discount rate applied has been selected from a World Bank study on Mexico, assumed at 12\% (World Bank 2014).

Finally, reference fuel costs of natural gas for NGCC electricity generation is assumed at 36.85 US\$/MWh based on CFE calculations with a timeframe of 30 years and $12 \%$ discount rate (CFE 2012).

The total disaggregated final demand vectors for the investment and O\&M phases for both technologies, taking into account the above mentioned working assumptions, can be consulted at Supplementary Materials in Appendix 4.5. 


\subsubsection{WIOT and socioeconomic, environmental and social data sources}

The last World Input Output Table (WIOT) available is from 2011. Socioeconomic and environmental vectors have been calculated with WIOD satellite accounts when available. A detailed explanation of the assumptions and data used in each impact assessment is provided below.

Socioeconomic accounts used in this case study from WIOD database are: gross value added (millions of national currency), number of persons engaged (thousands), total hours worked by persons engaged (millions) and compensation of employees (in millions of national currency). Data from 2011 was complete for "Gross value added" and "Persons engaged". "Hours engaged" and "Compensation of employees" complete data was from 2009. The economic output used to calculate each vector corresponds to the same year as the account data used. For RoW region, only data was available for the assessment of production of good and services and added value creation. For detailed information, WIOD documents can be consulted (Erumban et al. 2012a; Gouma et al. 2014).

Environmental accounts used in this case study from WIOD database are energy use (in TJ) and emissions to air: $\mathrm{CO} 2$ (in $\mathrm{Gg}$ ) and $\mathrm{CH} 4, \mathrm{~N} 2 \mathrm{O}$, NOX, SOX, CO, NMVOC and NH3 (in tonnes). The last data available was from 2009, also for the RoW region. For more information, WIOD document can be consulted (Genty et al. 2012). Emissions to air were used to estimate impacts on these three categories: climate change, acidification and formation of photochemical oxidants. The characterization factors used within each impact category is displayed in Supplementary Materials in Appendix 4.6.

Additionally, a direct energy consumption from natural gas use in the operation phase has been assumed at $7234.24 \mathrm{KJ}$ per $\mathrm{kWh}$ of electricity, according to the reference NGCC data of the Mexican Electricity Federal Commission (CFE 2012). Moreover, to estimate the direct environmental emissions from natural gas during the operation activities of electricity generation, Emission Factors (EF) for reference NGCC data in Mexico have been assumed (Santoyo-Castelazo et al. 2011). Lack of data for some EF (NH3, CO) in Mexico has been overcome by considering US reference data (NREL 2000). Table S4.4 of the Supplementary Materials also summarizes EF used for calculations in the case study. 
Biodiversity affection was estimated with the global multiregional IO database EORA (EORA 2016), which has differentt sectorial disaggregation and countries than WIOD (Lenzen et al. 2013). It contains the "Total threatened species" account, done with figures from the year 2000 of the Theatened Species Red List of the International Union for Conservation of the Nature (IUCN) (IUCN 2015a). Threaneted species aggrouped by phylum and classes can be consulted at EORA database (EORA 2016). This data was adjusted for the 40 WIOD countries and 35 sectors, and the ouput used was from 2000 WIOD data.

With regards to social risk values, no data was available for United Kingdom, Ireland and Rusia. Moreover, the social categories "Community Insfrastructures" and "Governance" do not have sectorial disaggreation.

Finally, induced effects are calculated as the economic stimulation made by employees of the project. Assumptions used to calculate induced effects are based on data from (WIOD 2016) to obtain wages shares from labor costs and households saving rates from (OECD 2015). These assumptions by countries shares can be consulted in Supplementary Materials in Appendix 4.7.

\subsection{Results}

In this section, results for both projects are shown for each sustainability pillar, distinguishing between direct, indirect and induced effects; national and international effects as well as effects from the investment and O\&M phases of the projects. The last subsection includes integrated assessments of all sustainability pillars through FISA charts.

\subsubsection{Socioeconomic impacts}

Table 4.1 displays the direct and indirect socioeconomic impacts of both projects in absolute terms and in relative terms inside and outside Mexico.

Table 4.1 Direct and indirect socioeconomic effects distinguishing national and international effects for both technologies 


\begin{tabular}{|c|c|c|c|c|c|c|}
\hline \multicolumn{2}{|c|}{ Socioeconomic effects } & \multirow{2}{*}{$\begin{array}{l}\begin{array}{l}\text { PG\&S } \\
\text { (\$/MWh) }\end{array} \\
14.5\end{array}$} & \multirow{2}{*}{$\begin{array}{l}\begin{array}{l}\text { Added } \\
\text { value } \\
\text { (\$/MWh) }\end{array} \\
6.6\end{array}$} & \multirow{2}{*}{$\begin{array}{l}\begin{array}{l}\text { Employments } \\
\text { (Jobs per } \\
\text { GWh) }\end{array} \\
0.1\end{array}$} & \multirow{2}{*}{$\begin{array}{l}\begin{array}{l}\text { Working } \\
\text { hours (WH } \\
\text { per GWh) }\end{array} \\
104.6\end{array}$} & \multirow{2}{*}{$\begin{array}{l}\begin{array}{l}\text { Wages (\$ } \\
\text { per } \\
\text { GWh) }\end{array} \\
4141.3 \\
\end{array}$} \\
\hline STE Direct & International & & & & & \\
\hline & Mexico & 41.6 & 24.8 & 1.0 & 1331.3 & 6021.5 \\
\hline \multirow{2}{*}{$\begin{array}{l}\text { STE } \\
\text { Indirect } \\
\text { effects }\end{array}$} & International & 29.5 & 11.3 & 0.5 & 495.5 & 5873.5 \\
\hline & Mexico & 17.7 & 11.0 & 0.5 & 877.8 & 2655.0 \\
\hline \multirow{2}{*}{$\begin{array}{l}\text { NGCC } \\
\text { Direct } \\
\text { effects }\end{array}$} & International & 3.7 & 1.7 & 0.0 & 31.6 & 877.4 \\
\hline & Mexico & 49.1 & 19.9 & 0.9 & 1083.3 & 5522.6 \\
\hline \multirow{2}{*}{$\begin{array}{l}\text { NGCC } \\
\text { Indirect } \\
\text { effects }\end{array}$} & International & 29.1 & 9.9 & 0.4 & 422.6 & 4545.3 \\
\hline & Mexico & 32.6 & 17.8 & 0.8 & 1323.7 & 4051.3 \\
\hline
\end{tabular}

Source: Own elaboration

Total production of G\&S of both projects have similar figures (114 \$/MWh STE and 120 \$/MWh NGCC), mainly as a result from direct effects in the STE case and indirect effects in the NGCC case respectively. In terms of AV creation per MWh, STE shows a larger impact: 60.5 \$/MWh for STE vs. $51.3 \$ / \mathrm{MWh}$ for NGCC, being direct effects $52 \%$ for STE and 44\% for NGCC. In Mexico, the contribution of STE and NGCC to AV creation is $61 \%$ and $46 \%$ respectively, which can be compared to $34 \%$ for the Mexican electricity sector in 2011. This implies that the contribution of STE investments to Gross Domestic Product (GDP) in Mexico is larger than NGCC, and much larger than the average of the sector.

As for the increase in the demand of goods and services, the induced effects associated to STE and NGCC amount to 11.1 \$ $/ \mathrm{MWh}$ and 5.5 \$/MWh respectively, with an AV creation of 6.7 \$/MWh and 2 \$/MWh for each technology. These effects are primarily produced in Mexico for both technologies (55\% for STE P\&S and $61 \%$ for NGCC).

Total employment generated amounts to 2 employments per GWh in each technology, with special relevance of direct effects in Mexico. Additionally, total working hours (WH) amount to 2,809 WH per GWh for STE and 2,861 for NGCC. WH per employee result in 1,317 for STE and 1,323 for NGCC. Wages paid to employees show that 6.7 dollars are paid per hour worked for STE and 5.9 for NGCC, being direct wages 7.1 and 5.7 for STE and NGCC respectively. Wages in Mexico have a lower rate, paid similarly at $4 \$ \mathrm{~h}$ for both technologies. 
The contribution of the different phases to total effects is shown in Table 4.2.

Table 4.2 National and international socioeconomic effects of the two project phases

\begin{tabular}{|c|c|c|c|c|c|c|}
\hline \multicolumn{2}{|c|}{ Socioeconomic effects } & \multirow{2}{*}{$\begin{array}{l}\text { PG\&S } \\
\text { (\$/MWh) } \\
40.0\end{array}$} & \multirow{2}{*}{$\begin{array}{l}\begin{array}{l}\text { Added } \\
\text { value } \\
\text { (\$/MWh) }\end{array} \\
16.1\end{array}$} & \multirow{2}{*}{$\begin{array}{l}\text { Employments } \\
\text { (Jobs per } \\
\text { GWh) } \\
0.6\end{array}$} & \multirow{2}{*}{$\begin{array}{l}\text { Working hours } \\
\text { (WH per GWh) } \\
544\end{array}$} & \multirow{2}{*}{$\begin{array}{l}\text { Wages }(\$ \\
\text { per GWh) } \\
9030\end{array}$} \\
\hline STE & International & & & & & \\
\hline $\begin{array}{l}\text { Investment } \\
\text { effects }\end{array}$ & Mexico & 33.8 & 18.5 & 1.1 & 1469 & 4431 \\
\hline \multirow{2}{*}{$\begin{array}{l}\text { STE O\&M } \\
\text { effects }\end{array}$} & International & 4.0 & 1.8 & 0.1 & 56 & 985 \\
\hline & Mexico & 25.6 & 17.3 & 0.4 & 740 & 4245 \\
\hline \multirow{2}{*}{$\begin{array}{l}\text { NGCC } \\
\text { Investment } \\
\text { effects }\end{array}$} & International & 10.7 & 4.3 & 0.2 & 158 & 2190 \\
\hline & Mexico & 10.8 & 6.4 & 0.4 & 522 & 1546 \\
\hline \multirow{2}{*}{$\begin{array}{l}\text { NGCC O\&M } \\
\text { effects }\end{array}$} & International & 22.2 & 7.4 & 0.3 & 296 & 3233 \\
\hline & Mexico & 70.9 & 31.3 & 1.3 & 1885 & 8028 \\
\hline
\end{tabular}

Source: Own elaboration

While most production of goods and services for STE takes place within the investment phase $(71 \%)$, for NGCC O\&M phase represents the largest share $(80 \%)$. AV creation from PG\&S in the investment phase results similar for both projects $(48 \%$ and $50 \%$ for STE and NGCC respectively), whereas in the operational phase STE results are greater (64\% STE and 41\% NGCC).

Regarding total job creation, STE shows the largest impact within the investment phase (78\%), from which $65 \%$ takes place in Mexico; whereas NGCC employments creation is higher in the operational phase (75\%), from which $83 \%$ takes places in Mexico.

In terms of $\mathrm{WH}$, the investment phase $(72 \%)$ has the largest contribution within STE technology), whereas in the NGCC $76 \%$ corresponds to the operational phase. Total wages in the investment phase are paid at a rate of 6.7 for STE and 5.5 for NGCC; and at 6.6 and 5.2 for STE and NGCC respectively in the O\&M phase. For both projects, national wages are lower than international wages.

Figure 4.1 displays the contribution of economic sectors of STE and NGCC to socioeconomic impacts. 


\begin{tabular}{|c|c|c|c|c|c|c|c|c|c|c|c|}
\hline \multirow[b]{3}{*}{ Country } & \multirow[b]{3}{*}{ Economic sector } & \multicolumn{10}{|c|}{ Contribution of economic sectors to socioeconomic impacts (percentaje from total contribution) } \\
\hline & & \multicolumn{2}{|c|}{ G\&S (\%) } & \multicolumn{2}{|c|}{ AV (\%) } & \multicolumn{2}{|c|}{ Jobs (\%) } & \multicolumn{2}{|c|}{ WH $(\%)$} & \multicolumn{2}{|c|}{ Wages (\%) } \\
\hline & & NGCC & STE & NGCC & STE & NGCC & STE & NGCC & STE & NGCC & STE \\
\hline CHN & Electrical and Optical Equipment & $0 \%$ & $0 \%$ & $0 \%$ & $0 \%$ & $0 \%[$ & $3 \%$ & $0 \%$ & $0 \%$ & $0 \%$ & $0 \%$ \\
\hline MEX & Mining and Quarrying & $4 \%$ 』 & $1 \%$ & $7 \%[\mathbb{]}$ & $2 \%$ & $0 \%$ & $0 \%$ & $0 \%$ & $0 \%$ & $0 \%$ & $0 \%$ \\
\hline MEX & Chemicals and Chemical Products & $2 \%$ & $0 \%$ & $0 \%$ & $0 \%$ & $3 \%$ & $0 \%$ & $2 \%$ & $0 \%$ & $0 \%$ & $0 \%$ \\
\hline MEX & Machinery, Nec & $0 \%$ & $0 \%$ & $0 \%$ & $0 \%$ & $0 \%[$ & $3 \%$ & $0 \%[$ & $3 \%$ & $0 \%$ & $2 \%$ \\
\hline MEX & Electrical and Optical Equipment & $0 \%$ ] & $2 \%$ & $0 \%$ & $0 \%$ & $3 \%[$ & $7 \%$ & $0 \%[]$ & $2 \%$ & $0 \% \|$ & $1 \%$ \\
\hline MEX & Electricity, Gas and Water Supply & $39 \%$ & $0 \%$ & $30 \%$ & $0 \%$ & $30 \%$ & $0 \%$ & $26 \%$ & $0 \%$ & $30 \%$ & $0 \%$ \\
\hline MEX & Construction & $0 \%[$ [ & $2 \%$ & $0 \%[$ & $2 \%$ & $5 \%[$ & $6 \%$ & $5 \%$ & $7 \%$ & $0 \%[$ & $3 \%$ \\
\hline MEX & Sale, Maintenance and Repair of Motor Vehicles & $0 \%$ & $0 \%$ & $0 \%$ & $0 \%$ & $3 \%[$ & $1 \%$ & $4 \%[$ & $2 \%$ & $0 \%$ & $0 \%$ \\
\hline MEX & Wholesale Trade and Commission Trade & $2 \%[$ & $2 \%$ & $4 \%[$ & $2 \%$ & $2 \%[$ & $1 \%$ & $4 \%[$ & $2 \%$ & $3 \% \|$ & $1 \%$ \\
\hline MEX & Retail Trade, Except of Motor Vehicles & $2 \%$ & $0 \%$ & $4 \%$ & $0 \%$ & $7 \%[$ & $2 \%$ & $11 \%[$ & $4 \%$ & $3 \%$ & $0 \%$ \\
\hline MEX & Hotels and Restaurants & $0 \%$ & $0 \%$ & $0 \%$ & $0 \%$ & $0 \%$ & $0 \%$ & $1 \%$ & $0 \%$ & $0 \%$ & $0 \%$ \\
\hline MEX & Inland Transport & $2 \%$ & $0 \%$ & $2 \%$ & $0 \%$ & $2 \%$ & $0 \%$ & $4 \%$ ] & $2 \%$ & $3 \%$ & $0 \%$ \\
\hline MEX & Financial Intermediation & $7 \%[$ & $24 \%$ & $10 \%[$ & $31 \%$ & $4 \%[$ & ] $2 \%$ & $5 \%[$ & $16 \%$ & $8 \%$ & $34 \%$ \\
\hline MEX & Real Estate Activities & $0 \%[$ & $2 \%$ & $3 \%[$ & $4 \%$ & $0 \%$ & $0 \%$ & $0 \%$ & $0 \%$ & $0 \%$ & $0 \%$ \\
\hline MEX & Renting of M\&Eq and Other Business Activities & $4 \%[$ & $8 \%$ & $6 \%[$ & $11 \%$ & $9 \%[$ & $17 \%$ & $12 \%$ & $24 \%$ & $7 \%$ & $11 \%$ \\
\hline USA & Chemicals and Chemical Products & $3 \%$ & $0 \%$ & $2 \%$ & $0 \%$ & $0 \%$ & $0 \%$ & $0 \%$ & $0 \%$ & $3 \%$ & $0 \%$ \\
\hline USA & Basic Metals and Fabricated Metal & $0 \%[$ & $6 \%$ & $0 \%[$ & $4 \%$ & $0 \%[$ & $3 \%$ & $0 \%$ ] & $2 \%$ & $0 \%$ & $8 \%$ \\
\hline USA & Machinery, Nec & $2 \%$ & $0 \%$ & $2 \%$ & $0 \%$ & $0 \%$ & $0 \%$ & $0 \%$ & $0 \%$ & $3 \%$ & $2 \%$ \\
\hline USA & Electrical and Optical Equipment & $0 \%[$ & $5 \%$ & $0 \%[$ & $6 \%$ & $0 \%$ & $0 \%$ & $0 \%$ & $0 \%$ & $0 \%$ & $18 \%$ \\
\hline USA & Electricity, Gas and Water Supply & $0 \%$ & $0 \%$ & $0 \%$ & $0 \%$ & $0 \%$ & $0 \%$ & $0 \%$ & $0 \%$ & $0 \%$ & $0 \%$ \\
\hline USA & Wholesale Trade and Commission Trade & $0 \%$ & $0 \%$ & $0 \% \llbracket$ & $1 \%$ & $0 \%$ & $0 \%$ & $0 \%$ & $0 \%$ & $2 \%$ 几 & $2 \%$ \\
\hline USA & Renting of M\&Eq and Other Business Activities & $0 \%$ & $2 \%$ & $0 \%[$ & $2 \%$ & $0 \%$ & $0 \%$ & $0 \%$ & $0 \%$ & $4 \%$ & $0 \%$ \\
\hline RoW & Mining and Quarrying & $0 \%$ & $0 \%$ & $0 \%$ & $0 \%$ & $0 \%$ & $0 \%$ & $0 \%$ & $0 \%$ & $0 \%$ & $0 \%$ \\
\hline \multicolumn{2}{|c|}{ Total contribution } & $66 \%$ & $54 \%$ & $72 \%$ & $65 \%$ & $68 \%$ & $56 \%$ & $74 \%$ & $63 \%$ & $65 \%$ & $80 \%$ \\
\hline
\end{tabular}

Figure 4.1 Contribution of sectors to socioeconomic impacts. Source: Own elaboration

While the Mexican financial intermediation sector has the largest contribution in almost all categories for STE, for the NGCC case, as expected, the Mexican electricity and gas sector appears to have the largest contribution in all categories as a result of the relevance of the demand of natural gas for the electricity production.

\subsubsection{Social risks impacts}

Table 4.3 displays the direct, indirect and total effects (measured by PSI values) across the five social categories distinguishing between national and international effects.

Table 4.3 Direct and indirect social effects differentiating national impacts in Mexico

\begin{tabular}{|c|c|c|c|c|c|c|}
\hline Social effects by impact & ategory & \multirow{2}{*}{$\begin{array}{l}\begin{array}{l}\text { Labor } \\
\text { risks (PSI } \\
\text { per GWh) }\end{array} \\
205\end{array}$} & \multirow{2}{*}{$\begin{array}{l}\begin{array}{l}\text { Health\&Safe } \\
\text { ty risks (PSI } \\
\text { per GWh) }\end{array} \\
196\end{array}$} & \multirow{2}{*}{$\begin{array}{l}\text { Human rights } \\
\text { risks (PSI per } \\
\text { GWh) } \\
154\end{array}$} & \multirow{2}{*}{$\begin{array}{l}\begin{array}{l}\text { Governance } \\
\text { risks (PSI } \\
\text { per GWh) }\end{array} \\
154\end{array}$} & \multirow{2}{*}{$\begin{array}{l}\begin{array}{l}\text { Infrastructure } \\
\text { s risks (PSI } \\
\text { per GWh) }\end{array} \\
139\end{array}$} \\
\hline STE Direct effects & International & & & & & \\
\hline & Mexico & 2931 & 3053 & 2340 & 4184 & 2092 \\
\hline \multirow[t]{2}{*}{ STE Indirect effects } & International & 1046 & 1389 & 1016 & 1007 & 803 \\
\hline & Mexico & 1940 & 2011 & 1544 & 2756 & 1378 \\
\hline \multirow[t]{2}{*}{ NGCC Direct effects } & International & 64 & 57 & 47 & 48 & 43 \\
\hline & Mexico & 2227 & 2484 & 1930 & 3405 & 1702 \\
\hline \multirow[t]{2}{*}{ NGCC Indirect effects } & International & 888 & 1177 & 871 & 870 & 688 \\
\hline & Mexico & 2899 & 3033 & 2340 & 4156 & 2078 \\
\hline
\end{tabular}

Source: Own elaboration 
With the exception of labor risks, total PSI values of NGCC result higher than STE. Direct effects for STE result higher mainly due to the greater value of $\mathrm{WH}$, as well as existence of social risks within some sectors such as in the renting of machinery and other business activities. For STE, around 50\% of PSI values in all categories are result from direct effects and around 30\% from indirect effects in Mexico. For NGCC, around $40 \%$ of PSI values results from direct effects and around $50 \%$ from indirect effects in Mexico. Direct and indirect effects of both technologies by social impact category can be consulted in Supplementary Materials in Appendix 4.8.

The contribution of each phase to social effects is displayed in Table 4.4, distinguishing impacts inside and outside Mexico

Table 4.4 Impacts in Mexico and outside Mexico in the investment and operation phases

\begin{tabular}{llrrrrr}
\hline Social effects by impact category & & $\begin{array}{l}\text { Labor } \\
\text { risks (PSI } \\
\text { per GWh) }\end{array}$ & $\begin{array}{l}\text { Health\&Safe } \\
\text { ty risks (PSI } \\
\text { per GWh) }\end{array}$ & $\begin{array}{l}\text { Human rights } \\
\text { risks (PSI per } \\
\text { GWh) }\end{array}$ & $\begin{array}{l}\text { Governance } \\
\text { risks (PSI } \\
\text { per GWh) }\end{array}$ & $\begin{array}{l}\text { Infrastructure } \\
\text { s risks (PSI } \\
\text { per GWh) }\end{array}$ \\
\hline STE Investment phase & International & 1136 & 1440 & 1064 & 1055 & 855 \\
& Mexico & 3242 & 3367 & 2589 & 4616 & 2308 \\
STE O\&M phase & International & 115 & 145 & 107 & 106 & 82 \\
& Mexico & 1628 & 1696 & 1295 & 2325 & 1162 \\
NGCC Investment & International & 339 & 426 & 317 & 314 & 254 \\
phase & Mexico & 1141 & 1195 & 920 & 1638 & 819 \\
NGCC O\&M phase & International & 613 & 808 & 602 & 604 & 477 \\
& Mexico & 3985 & 4322 & 3350 & 5922 & 2961 \\
\hline
\end{tabular}

Source: Own elaboration

For STE, results show that the most relevant social risks (depicted by the higher PSI values) take place in Mexico within the investment phase (around 50\%) and fewer during the operation phase (from 14 to $36 \%$ depending on the category). However, social risks during the investment phase are also relevant outside Mexican borders. For NGCC, around $70 \%$ of PSI values correspond to national effects during the operational phase while lower contributions correspond to national effects of the investment phase (around 20\%).

Figure 4.2 shows the contribution of sectors with the highest PSI values by social impact categories 


\begin{tabular}{|c|c|c|c|c|c|c|c|c|c|c|c|}
\hline \multirow[b]{3}{*}{ Country } & \multirow[b]{3}{*}{ Economic sectors } & \multicolumn{10}{|c|}{ Contribution of economic sectors to social dimension (in PSI units, percentaje from total contribution) } \\
\hline & & \multicolumn{2}{|c|}{ Labor rights PSI (\%) } & \multicolumn{2}{|c|}{ Health \& Safety PSI (\%) } & \multicolumn{2}{|c|}{ Human rights PSI (\%) } & \multicolumn{2}{|c|}{ Governance PSI (\%) } & \multicolumn{2}{|c|}{ Com. Insfrastructure PSI (\%) } \\
\hline & & NGCC & STE & NGCC & STE & NGCC & STE & NGCC & STE & NGCC & STE \\
\hline MEX & Other Non-Metallic Mineral & $0 \%$ & $4 \%$ & $0 \%$ & $4 \%$ & $0 \%$ & $4 \%$ & $0 \%$ & $5 \%$ & $0 \%$ & $4 \%$ \\
\hline MEX & Basic Metals and Fabricated Metal & $0 \%$ & $6 \%$ & $0 \%$ & $6 \%$ & $0 \%$ & $6 \%$ & $0 \%$ & $6 \%$ & $0 \%$ & $6 \%$ \\
\hline MEX & Machinery, Nec & $1 \%$ & $3 \%$ & $0 \%$ & $3 \%$ & $0 \%$ & $3 \%$ & $0 \%$ & $3 \%$ & $0 \%$ & $\exists \%$ \\
\hline MEX & Electrical and Optical Equipment & $0 \%$ & $2 \%$ & $0 \%$ & ]$_{2 \%}$ & $0 \%$ & $b_{2 \%}$ & $0 \%$ & ]$_{2 \%}$ & $0 \%$ & $2 \%$ \\
\hline MEX & Electricity, Gas and Water Supply & $24 \%$ & $0 \%$ & $25 \%$ & $0 \%$ & $26 \%$ & $0 \%$ & $28 \%$ & $0 \%$ & $26 \%$ & $0 \%$ \\
\hline MEX & Construction & $5 \%$ & $6 \%$ & $5 \%$ & $7 \%$ & $5 \%$ & $7 \%$ & $5 \%$ & $7 \%$ & $5 \%$ & $7 \%$ \\
\hline MEX & Sale, Maintenance, Repair of Motor Vehicles & $4 \%$ & $2 \%$ & $4 \%$ & $0 \%$ & $4 \%$ & $0 \%$ & $4 \%$ & \rfloor$_{2 \%}$ & $4 \%$ & $2 \%$ \\
\hline MEX & Wholesale Trade and Commission Trade & $4 \%$ & $2 \%$ & $4 \%$ & $2 \%$ & $4 \%$ & b\% & $4 \%$ & $\mathrm{~K}_{2} \%$ & $4 \%$ & \rfloor$_{2 \%}$ \\
\hline MEX & Retail Trade, Except of Motor Vehicles & $12 \%$ & $4 \%$ & $11 \%$ & $4 \%$ & $11 \%$ & $4 \%$ & $12 \%$ & $5 \%$ & $11 \%$ & $4 \%$ \\
\hline MEX & Inland Transport & $4 \%$ & $0 \%$ & $4 \%$ & $0 \%$ & $4 \%$ & $0 \%$ & $4 \%$ & $0 \%$ & $4 \%$ & $0 \%$ \\
\hline MEX & Financial Interme diation & $5 \%$ & $16 \%$ & $5 \%$ & $15 \%$ & $5 \%$ & $15 \%$ & $5 \%$ & $17 \%$ & $5 \%$ & $16 \%$ \\
\hline MEX & Renting of M\&Eq, Other Business Activities & $13 \%$ & $25 \%$ & $12 \%$ & $23 \%$ & $12 \%$ & $23 \%$ & $13 \%$ & $26 \%$ & $12 \%$ & $24 \%$ \\
\hline \multicolumn{2}{|c|}{ Total contribution } & $72 \%$ & $71 \%$ & $69 \%$ & $65 \%$ & $69 \%$ & $66 \%$ & $75 \%$ & $76 \%$ & $70 \%$ & $69 \%$ \\
\hline
\end{tabular}

Figure 4.2 Contribution of sectors with highest PSI values to social dimension by impact category. Source: Own elaboration

Averaging the five impact categories, the largest PSH for STE is the "renting of machinery and other business activities" sector while for the NGCC case it is the "electricity, gas and water supply" sector, both in Mexico. Main social risk existing in the largest PSH of both projects is displayed in Table 4.5. More information of other top PSH for both technologies can be consulted in Supplementary Materials in Appendix 4.9 .

Table 4.5 Average risk value of the largest PSH in each social category and riskiest social issues identified for both technologies 


\begin{tabular}{|c|c|c|c|c|}
\hline $\begin{array}{l}\text { Social impact } \\
\text { category }\end{array}$ & $\begin{array}{l}\text { NGCC PSH: } \\
\text { Electricity, gas } \\
\text { and water } \\
\text { supply. Average } \\
\text { risk value (from } \\
1 \text { to } 4 \text { ) }\end{array}$ & $\begin{array}{l}\text { STE PSH: Renting } \\
\text { of machinery and } \\
\text { other business } \\
\text { activities. Average } \\
\text { risk value (from } 1 \\
\text { to 4) }\end{array}$ & $\begin{array}{l}\text { Riskiest social issues identified within PSH of STE and } \\
\text { NGCC (or within both) }\end{array}$ & $\begin{array}{l}\text { Risk values of } \\
\text { riskiest social } \\
\text { issues within } \\
\text { PSH (risk } \\
\text { value higher } \\
\text { than 3) }\end{array}$ \\
\hline \multirow[t]{4}{*}{ Labor rights } & 1.97 & 2.09 & $\begin{array}{l}\text { NGCC- Risk that migrant workers are treated unfairly } \\
\text { (qualitative) }\end{array}$ & 4 \\
\hline & & & $\begin{array}{l}\text { STE- Risk of Sector Average Wage being lower than } \\
\text { Country's Minimum Wage }\end{array}$ & 4 \\
\hline & & & $\begin{array}{l}\text { STE- Risk that migrant workers are treated unfairly } \\
\text { (qualitative) }\end{array}$ & 4 \\
\hline & & & $\begin{array}{l}\text { STE- Risk of Child Labor in sector Male - Female } \\
\text { (quantitative) }\end{array}$ & 3 \\
\hline \multirow[t]{5}{*}{$\begin{array}{l}\text { Healt and } \\
\text { safety }\end{array}$} & 2.29 & 2.17 & $\begin{array}{l}\text { Both- Risk of loss of life years by mesothelioma due to } \\
\text { occupation }\end{array}$ & 3 \\
\hline & & & $\begin{array}{l}\text { Both- Risk of loss of life years by asthma due to } \\
\text { airborne particulates in occupation }\end{array}$ & 3 \\
\hline & & & $\begin{array}{l}\text { Both- Risk of loss of life years by chronic obstructive } \\
\text { pulmonary disease due to airborne particulates in } \\
\text { occupation }\end{array}$ & 3 \\
\hline & & & $\begin{array}{l}\text { Both- Risk of loss of life years by silicosis due to } \\
\text { airborne particulates in occupation }\end{array}$ & 3 \\
\hline & & & $\begin{array}{l}\text { Both- Risk of loss of life years by airborne particulates } \\
\text { in occupation }\end{array}$ & 3 \\
\hline Human rights & 1.80 & 1.63 & $\begin{array}{l}\text { Both- High Conflict Zones: Characterization of } \\
\text { Heidelberg Barometer }\end{array}$ & 4 \\
\hline Governance & 3.14 & 3.14 & $\begin{array}{l}\text { Both- Legal System: Characterization of Cingranelli- } \\
\text { Richards Human Rights Dataset - Independent } \\
\text { Judiciary }\end{array}$ & 4 \\
\hline $\begin{array}{l}\text { Commun.Infr } \\
\text { astructures }\end{array}$ & 1.57 & 1.57 & $\begin{array}{l}\text { Both- Access to Hospital Beds: Risk that there are too } \\
\text { few hospital beds to support population }\end{array}$ & 3 \\
\hline
\end{tabular}

Source: Own elaboration based on SHDB

These results indicate that when developing a NGCC or a STE project in Mexico, special attention should be devoted to the potential social risks in certain sectors of the economy (as indicated in the last column of Table 4.5)

One discrepancy may emerge by looking at the social and socioeconomic assessments in terms of labor conditions results. While socioeconomic impacts indicate better labor conditions (quality employment) from STE (less working hours and large wages), PSI values of labor rights social category result higher than NGCC. These differences could be mainly related to some social risks within the largest PSH (Table 4.5): low risks within the electricity and gas sector for NGCC and high risks in the 
renting of machinery and other business activities sector for STE. Namely, these differences between PSH can be found within the following social risks issues:

(i) Wage assessment: risk of sector average wage being lower than country's minimum wage. For this social risk issue, the electricity sector has a medium risk value, while the renting of machinery has a very high risk value. This is consistent with results obtained from the socioeconomic assessment, where the renting of machinery have a $11 \%$ contribution to total STE wages results and the electricity sector has a $30 \%$ contribution to total NGCC wages.

(ii) Child labor: risk of child labor in sector, female (quantitative) and male (quantitative). For these social issues, the electricity sector has a low risk value (both for male and female), while the renting of machinery sector has a high risk value (both male and female).

Additionally, as it can be seen in Table 4.5, the average social risk value for labor rights category of the renting of machinery sector is higher (2.09) than the electricity sector (1.97). Moreover, other PSH of STE (e.g. other non-metallic minerals or metals sector) have very high risks in some social issues (e.g. child labor or migrant workers treated unfairly). It is also important to take into account possible mistakes under the social database (e.g. very high child labor risks on financial sector or discrepancies between average male-female risk values and total child labor risks values). Finally, labor conditions results from socioeconomic assessment are only based on number of employees, working hours and wages; while the social risk assessment within the labor rights impact category take into account more and different social themes (see Appendix 4.1).

\subsubsection{Environmental impacts}

As in the previous sustainability pillars, Table 4.6 shows direct, indirect and total environmental effects distinguishing between national and international impacts

Table 4.6 Direct and indirect environmental effects in Mexico and outside Mexico

\begin{tabular}{lllllll}
\hline Environmental effects & & $\begin{array}{l}\text { Energy } \\
\text { consumption } \\
(\mathbf{M J} / \mathbf{k W h})\end{array}$ & $\begin{array}{l}\text { Climate } \\
\text { Change }(\mathbf{g} \\
\left.\mathbf{C O}_{2} \mathbf{e q} / \mathbf{k W h}\right)\end{array}$ & $\begin{array}{l}\text { Acidification } \\
(\mathbf{g ~ S O} \\
\mathbf{e q} / \mathbf{k W h})\end{array}$ & $\begin{array}{l}\text { Photoch. } \\
\text { oxidants }(\mathrm{g} \\
\mathbf{N M V O C} \\
\mathbf{e q} / \mathbf{k W h})\end{array}$ & $\begin{array}{l}\text { Percentage of } \\
\text { affection to } \\
\text { threatened } \\
\text { species }^{\mathbf{a}}\end{array}$ \\
\hline STE Direct effects & $\begin{array}{l}\text { International } \\
\text { Mexico }\end{array}$ & 0.03 & 1.4 & 0.00 & 0.01 & 0.0000 \\
& 0.10 & 7.5 & 0.02 & 0.04 & 0.0004 \\
\hline
\end{tabular}




\begin{tabular}{lllllll}
\hline STE Indirect effects & International & 0.24 & 9.4 & 0.04 & 0.05 & 0.0006 \\
& Mexico & 0.13 & 5.7 & 0.02 & 0.04 & 0.0007 \\
NGCC Direct effects & International & 0.00 & 0.2 & 0.00 & 0.00 & 0.0000 \\
& Mexico & 10.14 & 558.2 & 1.46 & 0.0243 \\
NGCC Indirect effects & International & 0.49 & 11.6 & 0.05 & 0.08 & 0.0006 \\
& Mexico & 0.89 & 32.7 & 0.12 & 0.0048 \\
\hline
\end{tabular}

${ }^{a}$ Percentage of affection to threatened species figures on 2000 caused by total activities related with the project Source: Own elaboration

Results in Table 4.6 seem to indicate that it is in the environmental pillar where the largest differences between technologies exist. Compared to STE, NGCC shows the largest environmental burdens, mostly associated to the use of natural gas to produce electricity with NGCC technology in Mexico.

Differentiating between investment and O\&M phases, Table 4.7 shows effects by phases for both technologies.

Table 4.7 National and international environmental effects in the different project phases

\begin{tabular}{|c|c|c|c|c|c|c|}
\hline Environmental effects & & $\begin{array}{l}\text { Energy } \\
\text { consumption } \\
(\mathbf{M J} / \mathbf{k W h})\end{array}$ & $\begin{array}{l}\text { Climate } \\
\text { Change (g } \\
\mathrm{CO}_{2} \text { eq/kWh) }\end{array}$ & $\begin{array}{l}\text { Acidification } \\
\text { (g SO} \\
\text { eq/kWh) }\end{array}$ & $\begin{array}{l}\text { Photoch. } \\
\text { oxidants (g } \\
\text { NMVOC } \\
\text { eq/kWh) }\end{array}$ & $\begin{array}{l}\text { Percentage of } \\
\text { affection to } \\
\text { threatened } \\
\text { species }^{\text {a }}\end{array}$ \\
\hline \multirow[t]{2}{*}{ STE Investment effects } & International & 0.18 & 9.98 & 0.04 & 0.06 & 0.0006 \\
\hline & Mexico & 0.18 & 10.84 & 0.03 & 0.06 & 0.0007 \\
\hline \multirow[t]{2}{*}{ STE O\&M effects } & International & 0.02 & 0.82 & 0.00 & 0.01 & 0.0000 \\
\hline & Mexico & 0.05 & 2.36 & 0.01 & 0.01 & 0.0004 \\
\hline \multirow{2}{*}{$\begin{array}{l}\text { NGCC Investment } \\
\text { effects }\end{array}$} & International & 0.06 & 2.44 & 0.01 & 0.01 & 0.0001 \\
\hline & Mexico & 0.04 & 1.95 & 0.01 & 0.01 & 0.0003 \\
\hline \multirow[t]{2}{*}{ NGCC O\&M effects } & International & 0.43 & 9.37 & 0.04 & 0.07 & 0.0005 \\
\hline & Mexico & 10.99 & 588.96 & 1.57 & 2.06 & 0.0288 \\
\hline
\end{tabular}

${ }^{a}$ Percentage of affection to threatened species figures on 2000 caused by total activities related with the project

Source: Own elaboration

The larger environmental impacts occur during the operational phase of NGCC in Mexico due to the fuel use for electricity production. In the case of STE, most environmental impacts are caused by the indirect effects during the investment phase outside Mexico.

Accounting for total effects, total energy consumption for STE amounts to 0.5 $\mathrm{MJ} / \mathrm{kWh}$, which is in agreement with published values of similar power plants which range $0.14-1.1 \mathrm{MJ} / \mathrm{kWh}$. For NGCC, total energy consumption amounts to 11.7 $\mathrm{MJ} / \mathrm{kWh}$, from which $1.5 \mathrm{MJ} / \mathrm{kWh}$ are indirect effects and 10.2 are direct effects. 
Values from Life Cycle Analysis estimations from the literature range between 7.8 and 8.4 MJ/kWh. The higher results obtained in this study are not surprising since MRIO results are expected to be larger due to the fact that there is no need to set system limits to the processes analyzed (Suh et al 2006).

Global warming emissions of STE amount to $24 \mathrm{~g} \mathrm{CO}_{2} \mathrm{eq} / \mathrm{kWh}$, which is in agreement with LCA results from literature (Burkhardt et al. 2012). For NGCC, results of total global warming emissions amount to $634 \mathrm{~g} \mathrm{CO}_{2} \mathrm{eq} / \mathrm{kWh}$. Harmonized LCA estimations of global warming emissions of this technology range from 440 to 780 . Results from acidification and photochemical oxidant formation for STE are $0.08 \mathrm{~g} \mathrm{SO}_{2}$ $\mathrm{eq} / \mathrm{kWh}$ and $0.14 \mathrm{~g}$ NMVOC eq/ $\mathrm{kWh}$ respectively. Not surprisingly, this figure is lower than another MRIO assessment of a hybrid STE with natural gas due to the effects of hybridization (Corona et al. 2016b). For NGCC, values amount to $1.6 \mathrm{~g} \mathrm{SO}_{2} \mathrm{eq} / \mathrm{kWh}$

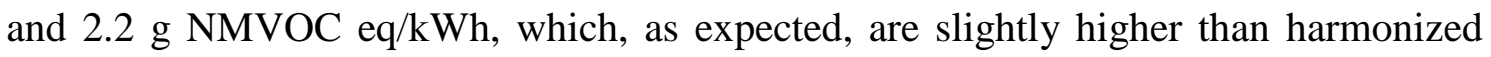
LCA estimations (Singh et al. 2011).

With regards to biodiversity, results show that NGCC activities throughout their whole life cycle would affect 18 times more threatened species than STE. This difference is caused mainly by the larger stimulation of the electricity and natural gas sector of NGCC and the larger related environmental impacts produced.

A summary of the total environmental impacts of both projects and comparison of results with similar assessment from literature are displayed in Supplementary Materials in Appendix 4.10.

Regarding main sectors responsible for total environmental impacts, Figure 4.3 displays sectors contribution for both technologies. 


\begin{tabular}{|c|c|c|c|c|c|c|c|c|c|c|c|}
\hline \multirow[b]{3}{*}{ Country } & \multirow[b]{3}{*}{ Economic sector } & \multicolumn{10}{|c|}{ Contribution of economic sectors to environmental impacts (percentaje from total contribution) } \\
\hline & & \multicolumn{2}{|c|}{ Energy Use (\%) } & \multicolumn{2}{|c|}{ Climate change $(\%)$} & \multicolumn{2}{|c|}{ Acidification (\%) } & \multicolumn{2}{|c|}{$\begin{array}{c}\text { Photochemical oxidants } \\
(\%)\end{array}$} & \multicolumn{2}{|c|}{$\begin{array}{c}\text { Total species } \\
\text { threatened }(\%)\end{array}$} \\
\hline & & NGCC & STE & NGCC & STE & NGCC & STE & NGCC & STE & NGCC & STE \\
\hline BEL & Renting of $\mathrm{M} \& \mathrm{Eq}$ and Other B.A. & $0 \%$ & $0 \%$ & $0 \%$ & $0 \%$ & $0 \%$ & $0 \%$ & $0 \%$ & $0 \%$ & $0 \%$ & $0 \%$ \\
\hline $\mathrm{CHN}$ & Agriculture, Forestry and Fishing & $0 \%$ & $0 \%$ & $0 \%$ & $0 \%$ & $0 \%$ & $3 \%$ & $0 \%$ & $0 \%$ & $0 \%$ & $0 \%$ \\
\hline $\mathrm{CHN}$ & Chemicals and Chemical Products & $0 \%$ & $0 \%$ & $0 \%$ & $0 \%$ & $0 \%$ & $0 \%$ & $0 \%$ & $0 \%$ & $0 \%$ & $0 \%$ \\
\hline $\mathrm{CHN}$ & Basic Metals and Fabricated Metal & $0 \%$ & $0 \%$ & $0 \%$ & $0 \%$ & $0 \%$ & $0 \%$ & $0 \%$ & $0 \%$ & $0 \%$ & $0 \%$ \\
\hline $\mathrm{CHN}$ & Electricity, Gas and Water Supply & $0 \%$ & $2 \%$ & $0 \%[$ & $4 \%$ & $0 \%$ & $7 \%$ & $0 \%$ & $0 \%$ & $1 \%$ & $14 \%$ \\
\hline DEU & Chemicals and Chemical Products & $0 \%$ & $2 \%$ & $0 \%$ & $0 \%$ & $0 \%$ & $0 \%$ & $0 \%[$ & $3 \%$ & $0 \%$ & $0 \%$ \\
\hline DEU & Electricity, Gas and Water Supply & $0 \%$ & $0 \%$ & $0 \%$ & $0 \%$ & $0 \%$ & $0 \%$ & $0 \%$ & $0 \%$ & $0 \%$ & $3 \%$ \\
\hline MEX & Agriculture, Forestry and Fishing & $0 \%$ & $0 \%$ & $0 \%$ & $0 \%$ & $0 \%$ & $3 \%$ & $0 \%$ & $0 \%$ & $0 \%$ & $2 \%$ \\
\hline MEX & Mining and Quarrying & $0 \%$ & $0 \%$ & $0 \%$ & $2 \%$ & $0 \%$ & $0 \%$ & $0 \%$ & $2 \%$ & $0 \%$ & $1 \%$ \\
\hline MEX & Coke, Refined Petroleum, Nuclear Fuel & $2 \%[$ & $8 \%$ & $0 \%$ & $0 \%$ & $0 \%$ & $0 \%$ & $5 \%[$ & $10 \%$ & $0 \%$ & $0 \%$ \\
\hline MEX & Chemicals and Chemical Products & $0 \%$ & $0 \%$ & $0 \%$ & $0 \%$ & $0 \%$ & $0 \%$ & $0 \%$ & $0 \%$ & $0 \%$ & $0 \%$ \\
\hline MEX & Rubber and Plastics & $0 \%$ & $0 \%$ & $0 \%$ & $0 \%$ & $0 \%$ & $0 \%$ & $0 \%$ & $0 \%$ & $0 \%$ & $0 \%$ \\
\hline MEX & Other Non-Metallic Mineral & $0 \%$ & $7 \%$ & $0 \%$ & $17 \%$ & $0 \%$ & $14 \%$ & $0 \%$ & $15 \%$ & $0 \%$ & $0 \%$ \\
\hline MEX & Basic Metals and Fabricated Metal & $0 \%$ & $8 \%$ & $0 \%$ & $10 \%$ & $0 \%$ & $5 \%$ & $0 \%$ & $8 \%$ & $0 \%$ & $0 \%$ \\
\hline MEX & Electricity, Gas and Water Supply & $93 \%$ & $13 \%$ & $97 \%$ & $13 \%$ & $95 \%$ & $15 \%$ & $89 \% 6$ & $5 \%$ & $97 \%$ & $32 \%$ \\
\hline MEX & Construction & $0 \%$ & $0 \%$ & $0 \%$ & $0 \%$ & $0 \%$ & $0 \%$ & $0 \%[$ & $3 \%$ & $0 \%$ & $8 \%$ \\
\hline MEX & Inland Transport & $0 \%$ & $0 \%$ & $0 \%$ & $0 \%$ & $0 \%$ & $2 \%$ & $0 \%[$ & $3 \%$ & $0 \%$ & $0 \%$ \\
\hline MEX & Financial Intermediation & $0 \%$ & $0 \%$ & $0 \%$ & $2 \%$ & $0 \%$ & $0 \%$ & $0 \%$ & $0 \%$ & $0 \%$ & $2 \%$ \\
\hline MEX & Renting of $M \& E q$ and Other B.A. & $0 \%$ & $0 \%$ & $0 \%[$ & $2 \%$ & $0 \%$ & $0 \%$ & $0 \%$ & $0 \%$ & $0 \%$ & $14 \%$ \\
\hline RUS & Electricity, Gas and Water Supply & $0 \%$ & $0 \%$ & $0 \%$ & $0 \%$ & $0 \%$ & $0 \%$ & $0 \%$ & $0 \%$ & $0 \%$ & $4 \%$ \\
\hline USA & Agriculture, Forestry and Fishing & $0 \%$ & $0 \%$ & $0 \%$ & $0 \%$ & $0 \%$ & $0 \%$ & $0 \%$ & $0 \%$ & $0 \%$ & $0 \%$ \\
\hline USA & Mining and Quarrying & $0 \%$ & $0 \%$ & $0 \%$ & $2 \%$ & $0 \%$ & $0 \%$ & $0 \%$ & $0 \%$ & $0 \%$ & $0 \%$ \\
\hline USA & Coke, Refined Petroleum, Nuclear Fuel & $2 \%$ & $9 \%$ & $0 \%$ & $0 \%$ & $0 \%$ & $2 \%$ & $0 \%$ & $0 \%$ & $0 \%$ & $0 \%$ \\
\hline USA & Chemicals and Chemical Products & $0 \%$ & $0 \%$ & $0 \%$ & $0 \%$ & $0 \%$ & $0 \%$ & $0 \%$ & $0 \%$ & $0 \%$ & $0 \%$ \\
\hline USA & Rubber and Plastics & $0 \%$ & $0 \%$ & $0 \%$ & $0 \%$ & $0 \%$ & $0 \%$ & $0 \%$ & $0 \%$ & $0 \%$ & $0 \%$ \\
\hline USA & Other Non-Metallic Mineral & $0 \%$ & $0 \%$ & $0 \%$ & $0 \%$ & $0 \%$ & $0 \%$ & $0 \%$ & $0 \%$ & $0 \%$ & $0 \%$ \\
\hline USA & Basic Metals and Fabricated Metal & $0 \%[$ & $5 \%$ & $0 \%$ & $6 \%$ & $0 \%$ & $5 \%$ & $0 \%[$ & $5 \%$ & $0 \%$ & $0 \%$ \\
\hline USA & Machinery, Nec & $0 \%$ & $0 \%$ & $0 \%$ & $0 \%$ & $0 \%$ & $0 \%$ & $0 \%$ & $0 \%$ & $0 \%$ & $0 \%$ \\
\hline USA & Electrical and Optical Equipment & $0 \%$ & $0 \%$ & $0 \%$ & $0 \%$ & $0 \%$ & $0 \%$ & $0 \%$ & $0 \%$ & $0 \%$ & $0 \%$ \\
\hline USA & Electricity, Gas and Water Supply & $0 \%[$ & $4 \%$ & $0 \%[$ & $4 \%$ & $0 \%$ & $4 \%$ & $0 \%$ & $0 \%$ & $0 \%$ & $6 \%$ \\
\hline Row & Agriculture, Forestry and Fishing & $0 \%$ & $0 \%$ & $0 \%$ & $0 \%$ & $0 \%$ & $0 \%$ & $0 \%$ & $0 \%$ & $0 \%$ & $0 \%$ \\
\hline Row & Coke, Refined Petroleum, Nuclear Fuel & $0 \%[$ & $2 \%$ & $0 \%$ & $0 \%$ & $0 \%$ & $0 \%$ & $1 \%$ & $4 \%$ & $0 \%$ & $0 \%$ \\
\hline Row & Chemicals and Chemical Products & $0 \%$ & $0 \%$ & $0 \%$ & $0 \%$ & $0 \%$ & $0 \%$ & $0 \%$ & $0 \%$ & $0 \%$ & $0 \%$ \\
\hline RoW & Electricity, Gas and Water Supply & $0 \%$ & $0 \%$ & $0 \%$ & $0 \%$ & $0 \%$ & $0 \%$ & $0 \%$ & $0 \%$ & $0 \%$ & $0 \%$ \\
\hline \multicolumn{2}{|c|}{ Total contribution } & $98 \%$ & $61 \%$ & $98 \%$ & $63 \%$ & $98 \%$ & $61 \%$ & $97 \%$ & $59 \%$ & $99 \%$ & $87 \%$ \\
\hline
\end{tabular}

Figure 4.3 Contribution of economic sectors to environmental impacts. Source: Own elaboration

For STE, the Mexican electricity sector is responsible for the largest impacts in energy consumption and threatened species. As for impacts on climate change and creation of photochemical oxidants categories, the nonmetallic mineral sector is responsible for the highest contribution due to material needed for heliostats and tower manufacturing. Both sectors have similar contribution to the acidification category. Regarding water consumption, the metal sector in Mexico is responsible for the largest share. As for the NGCC, most environmental impacts are the result of the activities of the Mexican electricity and gas sector, mainly from the use of natural gas in electricity generation. Only the coke and refined petroleum sector has a relative contribution within the photochemical oxidants creation category due to indirect effects. Finally, the activities 
from the electricity sector in both technologies are the ones responsible for the larger negative effects on the affection to threatened species.

\subsubsection{Sustainability impacts through FISA charts}

The FISA charts presented here allow to asses and view the three sustainability pillars simultaneously. For each impact, the contribution of each effect (direct/indirect; national/international and investment/O\&M phases) to the maximum impact reached by the assessed technologies is displayed. For more details of the underlying numbers represented in FISA charts, the corresponding sustainability section above can be consulted.

Figure 4.4 displays direct and indirect effects in the three sustainability pillars of both technologies

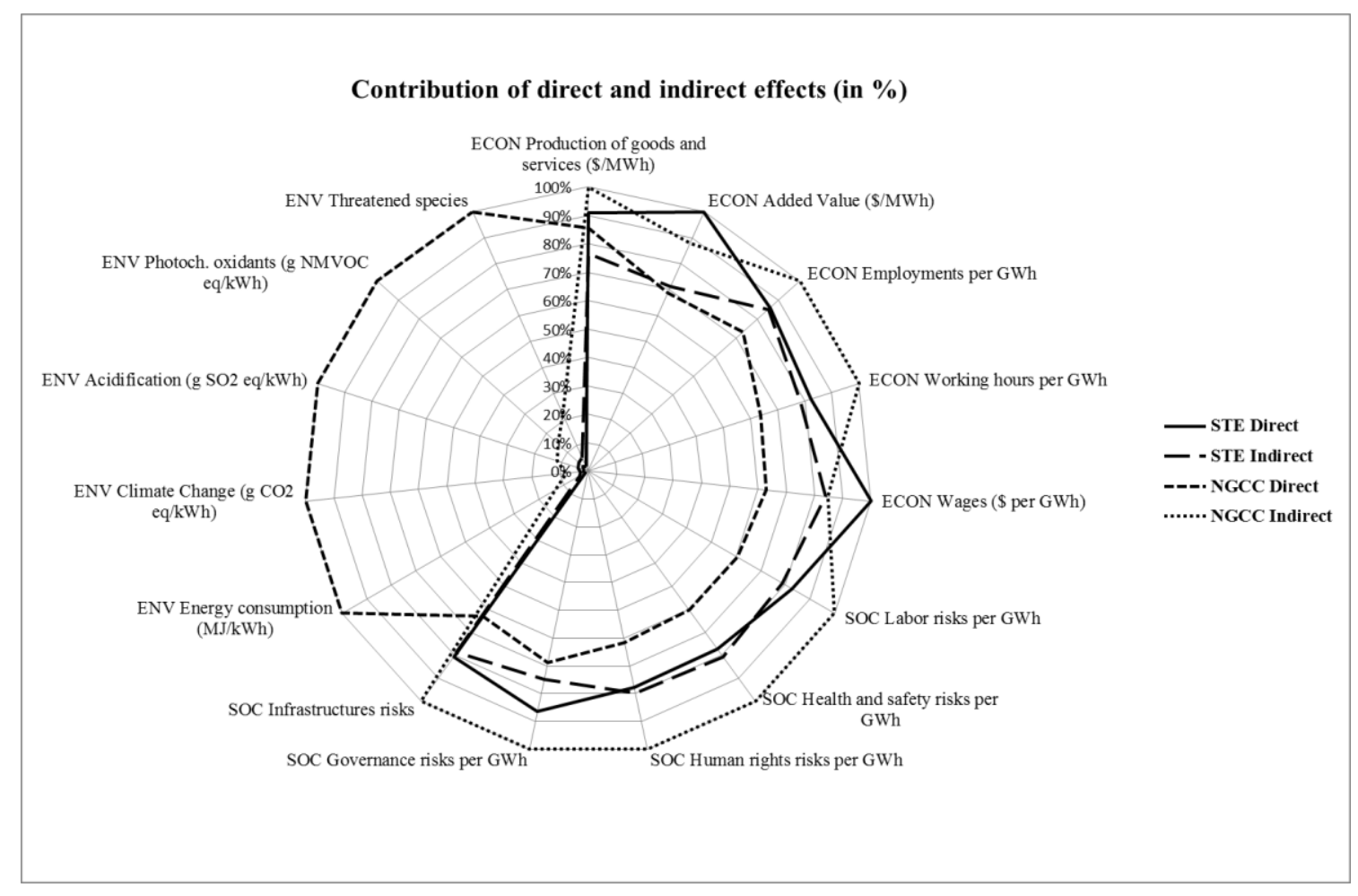

Figure 4.4 Contribution of direct and indirect effects to total effects of STE and NGCC. Source: Own elaboration

Indirect effects of NGCC and direct effects of STE have similar figures in terms of production of goods and services. However, direct effects of STE are larger in added value creation. Then, indirect effects of NGCC increase in employment and working hour shares, but they decrease in wages paid, in which direct effects of STE have larger 
impacts. Social effects occur mainly as a result of indirect effects of NGCC. Environmental impacts are mainly caused by direct effects from natural gas use for electricity production, being the lower values direct effects of STE.

Differentiating by national or international effects, Figure 4.5 shows contribution of both technologies

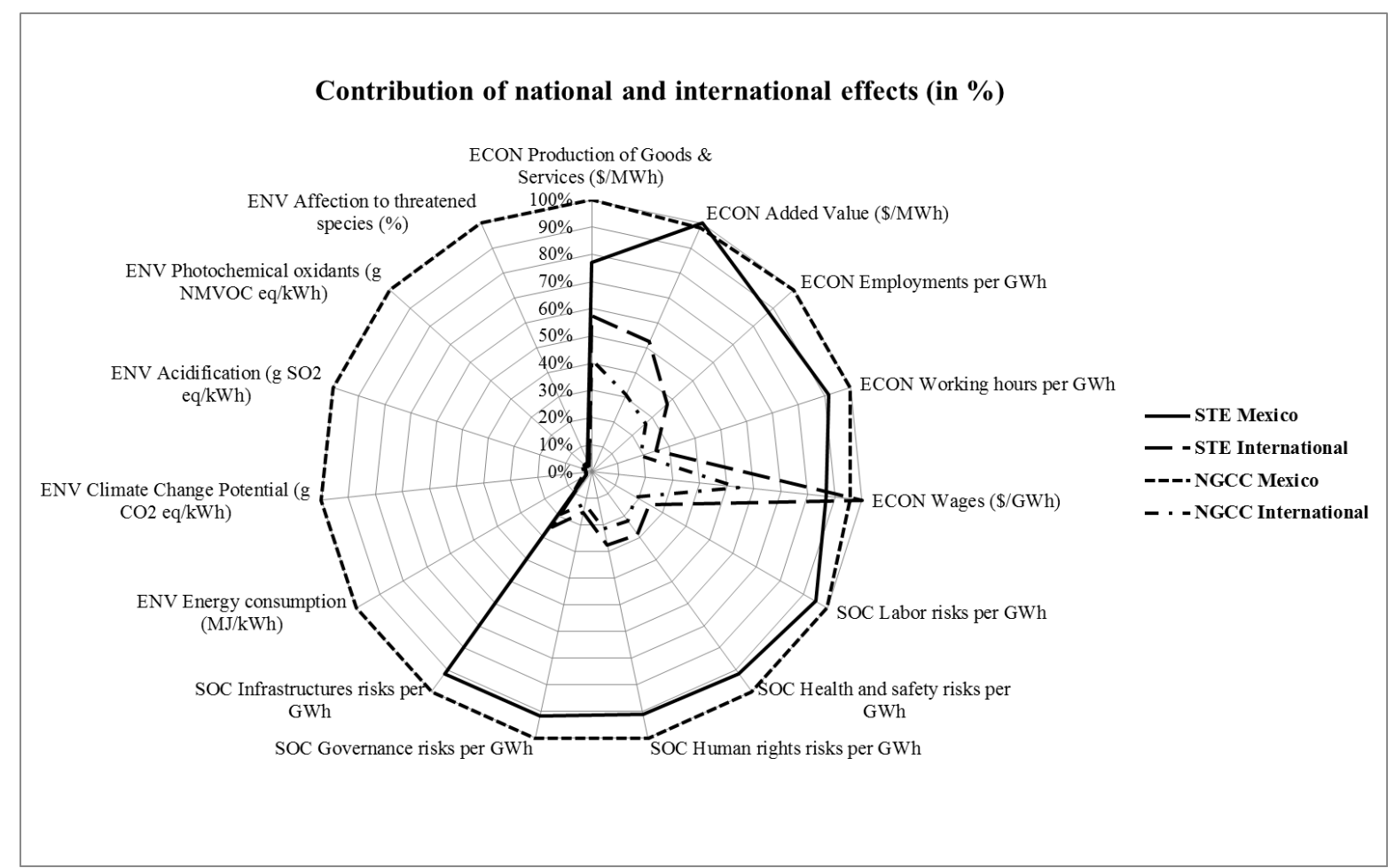

Figure 4.5 Contribution of effects inside and outside Mexico to total effects of STE and NGCC. Source: Own elaboration

Looking at Figure 4.4 and Figure 4.5, socioeconomic stimulation of NGCC comes mainly from indirect effects in a national scope, while STE effects come from direct effects in Mexico. Additionally, added value creation from STE in Mexico results large, STE wages from international scope are remarkable and NGCC indirect effects in Mexico are responsible for large employment and working hour figures, as well as higher results of social risks impacts. In terms of environmental impacts, NGCC direct effects in Mexico are responsible for the greatest impacts.

Effects by project phases are displayed in Figure 4.6. 


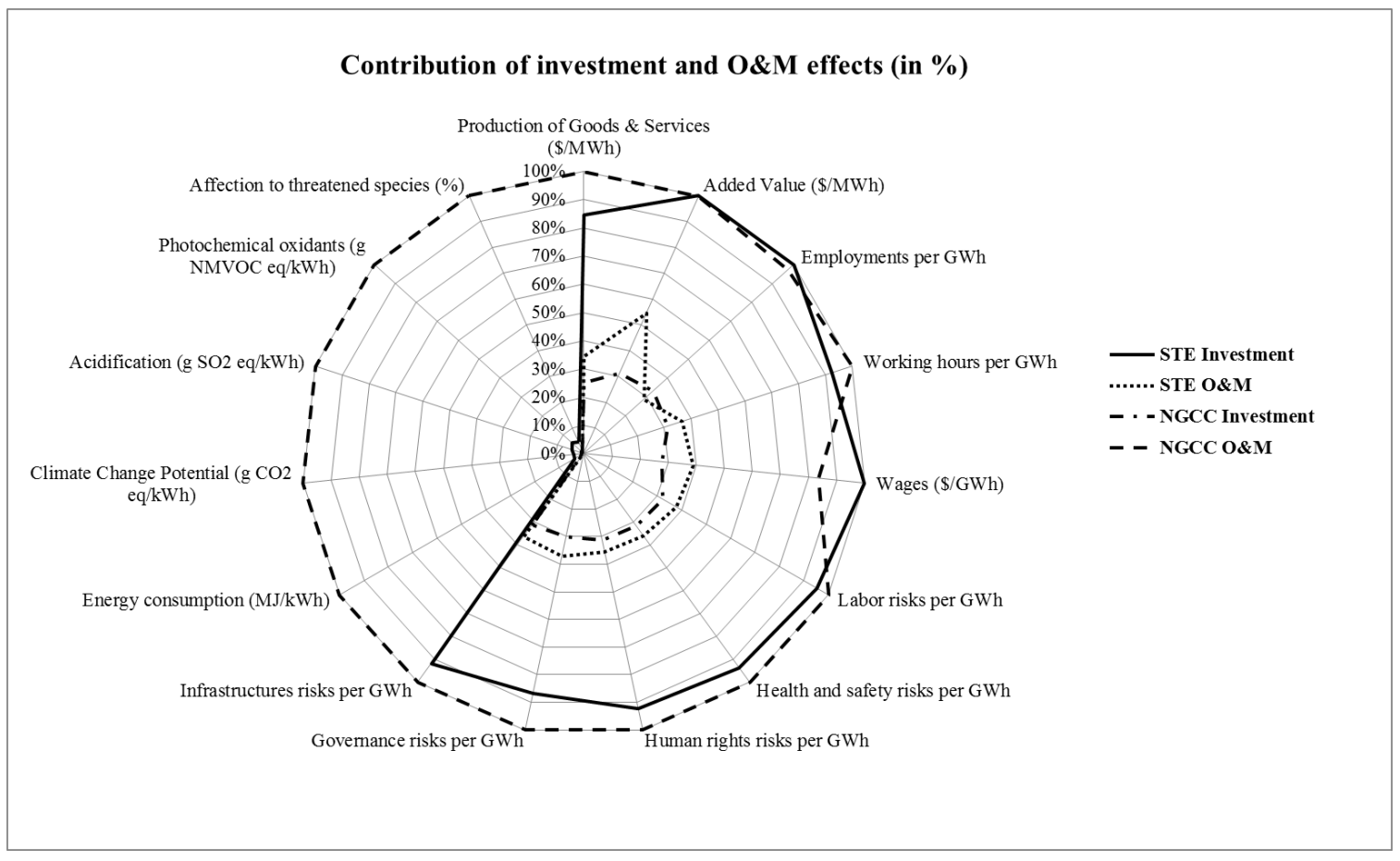

Figure 4.6 Contribution of effects of the investment and O\&M phases to total effects of STE and NGCC. Source: Own elaboration

Fig. 4.6 shows that the similar socioeconomic values of both projects are mainly caused by the investment phase of STE and the operational phase of NGCC. Again, NGCC shows larger job creation and WH figures while STE's wages are greater, which means quality employment. The operational phase of NGCC implies larger social risks as seen before mainly as a result of indirect effects in Mexico. Also the operational phase of NGCC is responsible for larger environmental effects in Mexico.

Finally, taking into account total effects, STE and NGCC have similar socioeconomic and social risk impacts, but STE creates more added value than NGCC (in more than 15\%) and therefore it has a higher impact on GDP. STE also shows higher wages than NGCC (in more than 20\%) and less working time, which means a better quality employment. Additionally, it is in the environmental pillar where greater differences exist mainly as a result of natural gas use for electricity production (NGCC negative environmental impacts result from 94 to $96 \%$ times more than STE). Figures on total effects and comparisons can be consulted in Supplementary Materials in Appendix 4.11.and they are graphically displayed in Supplementary Materials in Appendix 4.12. 
This impact assessment comparison could help Mexican decision makers when choosing between STE and NGCC for electricity production to satisfy the increasing demand. Based on these results, slightly larger production of goods and services associated to NGCC could be explained by the larger market development of this technology in Mexico. However, as STE becomes a more mature technology with greater market share, it is expected that similar socio-economic impacts could be achieved. Additionally, added value creation of STE results greater, and STE reflects better quality employments (less working hours, larger wages). Regarding sectorial social risk impacts, both technologies show similar results. Nevertheless, main activities or companies which may involve social risks could be easier to identify for STE as direct effects are larger responsible than indirect ones. Finally, NGCC negative environmental effects are remarkably larger than those associated to STE, mostly as a result from the direct use of natural gas to produce electricity. These results should be taken into account by decision makers when trying to achieve National climate change targets and aiming to promote a sustainable and secure energy system.

\subsection{Conclusions}

When assessing any investment project, it is important to take into account not only its technical and economic parameters, but also its impacts on the three sustainability pillars. In this sense, FISA (Framework for Integrated Sustainability Assessment) is presented as a useful framework to support the decision making process as it simultaneously captures a wide variety of impacts among the three sustainability pillars across economic sectors stimulated direct and indirectly by a project.

In this work, the FISA framework has been used to compare the impacts across the three sustainability pillars of two possible alternative electricity generation technologies in Mexico: Solar Thermal Electricity (STE) and Natural Gas Combined Cycle (NGCC). When taking into account the whole supply chain and embedded trade relationships, results show that despite NGCC and STE have similar impacts on the stimulation of the economy, some discrepancies between the two technologies emerge. Such differences can be summarized as follows: (i) value added creation of STE is larger than NGCC; (ii) both technologies have similar job creation impacts but NGCC shows large working hours and lower wages, implying that STE would lead to better 
quality employment; (iii) attention should be paid to certain social risks impacts in Mexico associated to STE direct effects of the investment phase and indirect effects of the operational phase of NGCC. These social risks could be minimized by verifying and monitoring social conditions and corporate practices of the main companies that provide goods and services, being in this case for STE easier to identify within direct activities involved. Finally, (iv) the negative environmental impacts associated to NGCC are much larger than for STE in all considered categories mainly due to natural gas used as fuel to produce electricity.

This work has shown that the use of the sustainability assessment framework FISA is a useful framework to inform decision makers about the impacts on the three sustainability pillars of alternative energy investment choices. As such, the consideration of the obtained results should incline them towards the optimal investment choice from a sustainability point of view.

\section{Acknowledgments}

Authors would like to thanks experts consulted in this work for their support and information provided. 


\title{
5. Comparing the Sustainability Impacts of Solar Thermal and Natural Gas Combined Cycle for Electricity Production in Mexico: Accounting for Decision Makers' Priorities ${ }^{11}$
}

\begin{abstract}
The aim of this paper is to conduct a comprehensive sustainability assessment of the electricity generation with two alternative electricity generation technologies by estimating its economic, environmental and social impacts through the "Framework for Integrated Sustainability Assessment" (FISA). Based on a Multiregional Input Output (MRIO) model linked to a social risk database (Social Hotspot Database), the framework accounts for up to fifteen impacts across the three sustainability pillars along the supply chain of the electricity production from Solar Thermal Electricity (STE) and Natural Gas Combined Cycle (NGCC) technologies in Mexico. Except for value creation, results show larger negative impacts for NGCC, particularly in the environmental pillar. Next, these impacts are transformed into "Aggregated Sustainability Endpoints" (ASE points) as a way to support the decision making in selecting the best sustainable project. ASE points obtained are later compared to the resulting points weighted by the reported priorities of Mexican decision makers in the energy sector obtained from a questionnaire survey. The comparison shows that NGCC achieves a 1.94 times worse negative score than STE, but after incorporating decision makers' priorities, the ratio increases to 2.06 due to the relevance given to environmental impacts such as photochemical oxidants formation and climate change potential, as well as social risks like human rights risks.
\end{abstract}

\footnotetext{
${ }^{11}$ Accepted in the American Institute of Physics (AIP) Conference Proceedings Journal (2017). Co-authored with Natalia Caldés (Energy Systems Analysis Unit, Energy Department, Technical, Environmental and Energy Research Centre (CIEMAT)), Christian Oltra and Roser Sala (Socio-Technique Research Centre (CISOT), Technical, Environmental and Energy Research Centre (CIEMAT). Authors would like to thank all interviewees consulted, the support from Dr. Antonio Rodríguez of the Universidad Auntónoma del Estado de Morelos and from Almudena Bailador of the Unit of Informatics Systems at Ciemat; and the valuable Reviewer's comments.
} 


\subsection{Introduction}

An increasing number of countries aiming for a more sustainable development are progressively substituting fossil fuel by renewable energy (RE) technologies. Mexico, under its current Strategy for Climate Change, has set a 35\% target of RE contribution to its electricity generation by 2024 (Secretaría General 2012). Moreover, the country is highly dependent from oil price fluctuations due to its large oil exports and natural gas imports (U.S. Energy Information Agency 2014). Having these concerns in mind, Solar Thermal Electricity (STE) could play a progressively important role in Mexico as a way to contribute to achieve the RE target as well as improve its energy security and electricity system management thanks to its energy storage capacity (Greenpeace et al. 2016).

In this sense, the aim of this paper is to conduct a comprehensive sustainability assessment of the electricity production from two alternative technologies in Mexico by estimating the economic, environmental and social impacts of STE and Natural Gas Combined Cycle (NGCC) electricity production through the "Framework for Integrated Sustainability Assessment" (FISA). In order to support decision making processes, final "sustainability points" and weighted points from stakeholders' priorities have been calculated to simplify the results and allow the comparison (Kuitunen et al. 2008).

The paper is structured as follows: in the next subsection, the methodological steps of the FISA framework are presented. Next, main results from the assessment and the survey case study are displayed and discussed. Finally, conclusions from this work are summarized.

\subsection{Methodology}

The "Framework for Integrated Sustainability Assessment" (FISA) is based on a combination of a Multiregional Input output analysis (MRIO) and a social risk database entitled "Social Hotspot Database" (SHDB). The combined framework allows for the simultaneously capture of the socioeconomic and environmental impacts as well as the social risks involved within the supply chain of projects (Rodríguez-Serrano et al. 2016b). The underlying methodological steps are shown in Figure 5.1. 


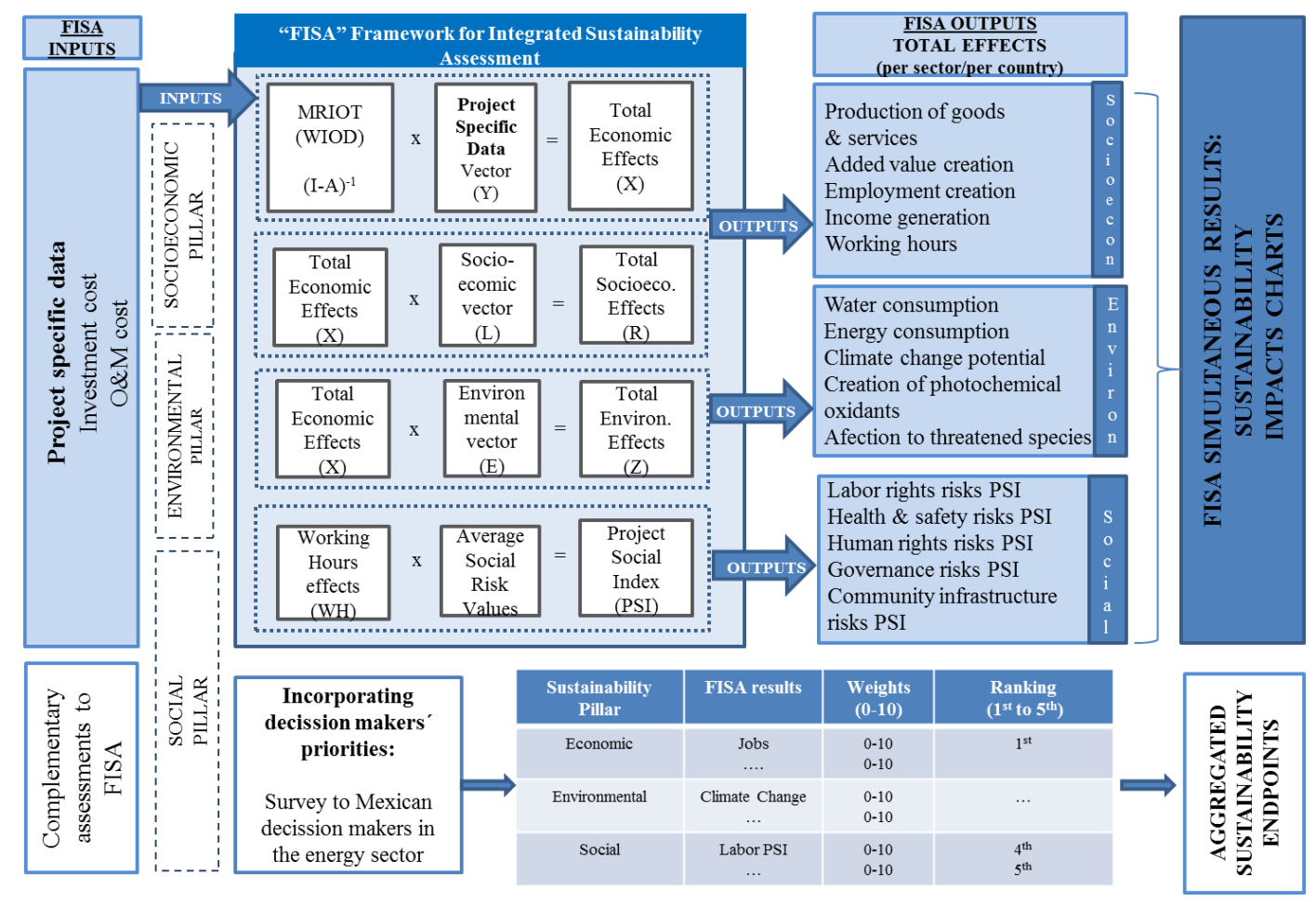

Figure 5.1. "Framework for Integrated Sustainability Assessment" methodological steps. Source: Own elaboration

MRIO assessment allows to analyze the economic sectors response of countries as a result of an increase of goods and services by a given project (Leontief 1936). Based on a MRIO Table (MRIOT), which describes the relationships among economic sectors; and projects costs data (investment and operation and maintenance "O\&M" costs); MRIO analysis allows to estimate indirect and direct effects (total effects) produced by the project through Equation 1, being indirect effects those related goods and services needed to satisfy the direct demand. Total effects can be estimated for the 40 countries and 35 economic sectors included in the World Input Output Database (WIOD) (WIOD 2016).

$$
\mathrm{x}=(\mathrm{I}-\mathrm{A})^{-1} \cdot \mathrm{y}
$$

where $\mathrm{x}$ is the total production of goods and services (total effects), $\mathrm{A}$ is the technical coefficient matrix, $(\mathrm{I}-\mathrm{A})^{-1}$ is the inverse of Leontief which represents direct and indirect effects and $\mathrm{y}$ is the required demand. 
An expansion of MRIO allows to incorporate socioeconomic or environmental vectors per monetary unit (e.g. $\mathrm{CO}_{2}$ emissions/\$) to estimate total socioeconomic or environmental impacts associated to such economic stimulation (Hendrickson et al. 1998). One of the socioeconomic impacts analyzed which is essential for the link with the SHDB is total hours worked.

The SHDB contains data on existing social risks across economic sectors classified in five categories (SHDB 2016). These social risk values vary from one (low risk) to four (very high risk) and are calculated by different characterization processes of the social indicators, normally by data distribution (e.g. quartiles) or expert consultation (Benoît et al. 2012).

The combination of the SHDB and MRIO within the FISA framework is conducted by multiplying the working hours results across the different WIOD economic sectors resulting from the MRIO assessment and the social risk values within the same WIOD sectors, resulting in the "Project Social Index" (PSI). The larger PSI values correspond to the "Project Social Hotspots" (PSH), which are sectors in which greater attention should be paid because they currently experience large social risks and also they would be larger stimulated by the project.

Once impacts within the three sustainability pillars have been estimated, it is then possible to simultaneously compare the magnitude of impacts between the analyzed technologies through FISA charts. These charts show the contribution of each impact to the maximum impact reached within a given category by the assessed technologies, expressed in percentage. Impacts assessed in this work are shown in Figure 5.1 (FISA outputs).

Additionally, given that decision makers may have their own priorities which could differ from the optimal result from FISA, a survey was conducted with decision makers mainly related to the energy sector in Mexico. The survey was sent in January 2016. Thirteen decision makers participated in the survey selected from official annual energy and electricity reports in Mexico, directories consulted from related Secretariats webpages and contact recommendations from personnel notifications. From those, seven participants work at the Secretariat of Energy, one works at the Secretariat of Environment, two work at the Secretariat of Sustainable Development, two work at the university and one works at a private company. 
Survey participants were asked to evaluate the relevance of the FISA impacts analyzed in their decision making processes. The survey included two types of evaluation of impacts. First, interviewees had to rate the proposed impacts in a 1 to 5 scale, where 1 means very little relevance in the decision making process and 5 means very high relevance. Second, interviewees were asked to select only five impacts and prioritize them in a 1 st to 5 th rank. The aim of the ranking assessment was to analyze if main priorities changed when decision makers were forced to reflect on their main relevant criteria. Averaged weighted and ranking scores are presented in a 0 to 1 scale.

In order to simplify the results and allow for the comparison of results obtained from FISA assessment and from decision makers' priorities, FISA impacts results were later transformed into "Aggregated Sustainability Points" in a -10 to +10 ranking scale, corresponding to negative or positive scores if the impact assessed had a negative or positive effect. Then, these points were weighted by the average rating and ranking scores from the survey to account for such preferences. The calculation of these points was based on (Pastakia and Jensen 1998), in which different processes or technologies achieve a specific score based on some characteristic of impacts (e.g. magnitude of change, reversibility or accumulation of impacts). In this case, two of these criteria were selected: (i) importance of impact, which corresponds to the 1 to 5 relevance of impacts from the stakeholders' survey; and (ii) magnitude of effects, which correspond to results from FISA assessment. By multiplying both terms and adding all points achieved in each impact, total sustainability points for each technology were obtained for the different assessments.

\subsection{Results and discussion}

Table 5.1 shows total effects in Mexico generated by the production of 11,871.4 GWh electricity with alternative STE and NGCC technologies from the FISA assessment (Rodríguez-Serrano et al. forthcoming). 
Table 5.1 FISA results for STE and NGCC in Mexico

\begin{tabular}{lcc}
\hline FISA Impacts & STE & NGCC \\
\hline Cost (\$/MWh)1 & 47.8 & 52.4 \\
Added Value Creation (\$/MWh) & 39.7 & 39.0 \\
Jobs per GWh & 1.5 & 1.7 \\
Working hours per GWh & 2209.2 & 2407.0 \\
Wages (\$ per GWh) & 8676.5 & 9574.0 \\
Labor PSI risks per GWh & 4870.5 & 5126.2 \\
Health and safety PSI risks per GWh & 5063.4 & 5516.8 \\
Human rights PSI risks per GWh & 3884.0 & 4270.3 \\
Governance PSI risks per GWh & 6940.3 & 7560.7 \\
Infrastructures PSI risks per GWh & 3470.1 & 3780.4 \\
Water consumption (1/kWh)2 & 1.0 & 1.1 \\
Energy consumption $\mathbf{( M J / k W h ) ~}$ & 228.8 & 11028.6 \\
Climate Change Potential (g CO2 eq/kWh) & 13.2 & 590.9 \\
Photochemical oxidants creation $(\mathbf{g}$ NMVOC & 0.08 & 2.1 \\
eq/kWh) & & \\
Affection to threatened species $(\%)$ & $0.001 \%$ & $0.03 \%$ \\
\hline
\end{tabular}

${ }^{1}$ Costs include direct investment and operation and maintenance costs occurred in Mexico (without imports)

${ }^{2}$ Water consumption only includes direct effects

Source: Own elaboration

NGCC achieves larger figures in all impacts except for the added value creation. As for the environmental pillar, greater differences exist from the use of natural gas as fuel. Figure 5.2 represents the FISA chart, where all impacts are simultaneously displayed and where $100 \%$ correspond to the maximum impact reached by technologies.

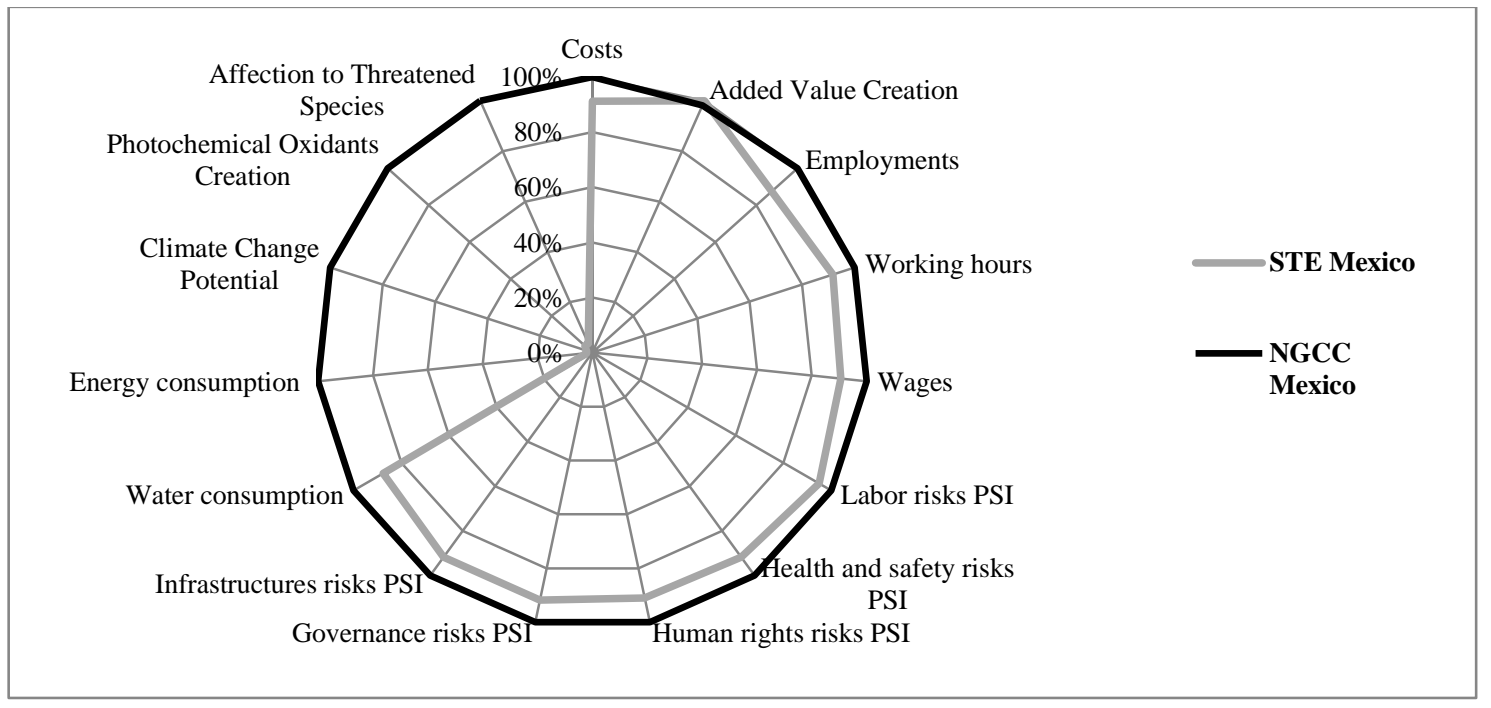

Figure 5.2 FISA results of total effects for STE and NGCC in Mexico. Source: Own elaboration 
In order to make these results easier to support the decision making process, impact figures have been transformed into the above mentioned ASE points (Aggregated Sustainability Endpoints). Additionally, stakeholders' preferences from the survey have been incorporated, both from the weighted and ranking assessments.

In the next subsections, ASE points and the resulting figures when considering decision makers' priorities are displayed for each sustainability pillar. A summary of results is structured in the subsequent tables for the two technologies: (i) FISA percentages results (first and second columns); (ii) ASE points (third and fourth columns); (iii) average weights from survey (fifth column); (iv) incorporation of weighted points (sixth and seventh columns); (v) average ranking from survey (eight column) and (vi) incorporation of ranking points (ninth and tenth columns).

\subsubsection{Socioeconomic Pillar}

Table 5.2 shows reference FISA \% results, ASE points, averaged weighted points and averaged ranking points for STE and NGCC assessed for socioeconomic impacts

Table 5.2 Reference FISA \% results, ASE points, averaged weighted points and averaged ranking points for STE and for socioeconomic impacts

\begin{tabular}{|c|c|c|c|c|c|c|c|c|c|c|}
\hline & $\begin{array}{c}\text { STE } \\
\text { FISA } \\
(\%)\end{array}$ & $\begin{array}{c}\text { NGCC } \\
\text { FISA } \\
(\%)\end{array}$ & $\begin{array}{c}\text { STE } \\
\text { ASE } \\
\text { points }\end{array}$ & $\begin{array}{l}\text { NGCC } \\
\text { ASE } \\
\text { points }\end{array}$ & $\begin{array}{l}\text { Aver. } \\
\text { Weight } \\
\text { s score }\end{array}$ & $\begin{array}{c}\text { STE } \\
\text { Weighte } \\
\text { d points }\end{array}$ & $\begin{array}{c}\text { NGCC } \\
\text { Weighted } \\
\text { points }\end{array}$ & $\begin{array}{l}\text { Aver. } \\
\text { Rank } \\
\text { score }\end{array}$ & $\begin{array}{c}\text { STE } \\
\text { Rank } \\
\text { points }\end{array}$ & $\begin{array}{c}\text { NGC } \\
\text { C } \\
\text { Rank } \\
\text { points }\end{array}$ \\
\hline $\begin{array}{l}\text { Costs } \\
\text { (Inv, } \\
\text { O\&M) }\end{array}$ & 91 & 100 & -9.1 & -10.0 & 0.72 & -6.59 & -7.23 & 0.68 & -6.20 & -6.80 \\
\hline $\begin{array}{l}\text { Added } \\
\text { Value }\end{array}$ & 100 & 98 & 10.0 & 9.8 & 0.75 & 7.54 & 7.40 & 0.44 & 4.40 & 4.32 \\
\hline Jobs & 88 & 100 & 8.8 & 10.0 & 0.72 & 6.33 & 7.23 & 0.40 & 3.50 & 4.00 \\
\hline $\begin{array}{l}\text { Work } \\
\text { hours }\end{array}$ & 92 & 100 & -9.2 & -10.0 & 0.57 & -5.22 & -5.69 & 0.00 & 0.00 & 0.00 \\
\hline Wages & 91 & 100 & 9.1 & 10.0 & 0.74 & 6.69 & 7.38 & 0.08 & 0.73 & 0.80 \\
\hline Total & - & - & 9.5 & 9.8 & - & 8.75 & 9.10 & - & 2.43 & 2.42 \\
\hline
\end{tabular}

Source: Own elaboration

Table 5.2 shows that, when looking at the ASE points, NGCC and STE achieve similar positive scores, with a difference of 0.3 ASE points. When incorporating weights, 
differences do not change because all indicators are weighted similarly, except for working hours. Regarding ranking scores, points achieved in both technologies are lower but almost equal between them because only costs are considered relevant.

\subsubsection{Social Pillar}

In this section, the social results are displayed in Table 5.3, following the same structure as above.

Table 5.3 Social risks for FISA results (in \%), ASE points, and averaged weighted and ranking points for STE and NGCC

\begin{tabular}{|c|c|c|c|c|c|c|c|c|c|c|}
\hline & $\begin{array}{c}\text { STE } \\
\text { FISA } \\
(\%)\end{array}$ & $\begin{array}{c}\text { NGCC } \\
\text { FISA } \\
(\%)\end{array}$ & $\begin{array}{c}\text { STE } \\
\text { ASE } \\
\text { points }\end{array}$ & $\begin{array}{l}\text { NGCC } \\
\text { ASE } \\
\text { points }\end{array}$ & $\begin{array}{l}\text { Aver. } \\
\text { Weight } \\
\text { s score }\end{array}$ & $\begin{array}{c}\text { STE } \\
\text { Weighte } \\
\text { d points }\end{array}$ & $\begin{array}{c}\text { NGCC } \\
\text { Weighted } \\
\text { points }\end{array}$ & $\begin{array}{l}\text { Aver. } \\
\text { Rank } \\
\text { score }\end{array}$ & $\begin{array}{l}\text { STE } \\
\text { Rank } \\
\text { points }\end{array}$ & $\begin{array}{l}\text { NGCC } \\
\text { Rank } \\
\text { points }\end{array}$ \\
\hline Labor risks & 95 & 100 & -9.5 & -10.0 & 0.75 & -7.16 & -7.54 & 0.44 & -4.18 & -4.40 \\
\hline $\begin{array}{l}\text { Health and } \\
\text { safety risks }\end{array}$ & 92 & 100 & -9.2 & -10.0 & 0.88 & -8.05 & -8.77 & 0.48 & -4.41 & -4.80 \\
\hline $\begin{array}{l}\text { Human rights } \\
\text { risks }\end{array}$ & 91 & 100 & -9.1 & -10.0 & 0.88 & -7.98 & -8.77 & 0.92 & -8.37 & -9.20 \\
\hline $\begin{array}{l}\text { Governance } \\
\text { risks }\end{array}$ & 92 & 100 & $-9,2$ & -10.0 & 0.74 & -6.78 & -7.38 & 0.20 & -1.84 & -2.00 \\
\hline $\begin{array}{l}\text { Infrastructure } \\
\text { risks }\end{array}$ & 92 & 100 & -9.2 & -10.0 & 0.75 & -6.92 & -7.54 & 0.24 & -2.20 & -2.40 \\
\hline Total & - & - & -46.1 & -50.0 & - & -36.9 & -40.0 & - & -21.0 & -22.8 \\
\hline
\end{tabular}

Source: Own elaboration

Here, NGCC achieves a worse score from larger social risks in all categories, with 3.9 ASE points of difference between technologies. When incorporating weights, this difference is similar (3.1 points) because all indicators are important to decision makers (high - very high relevance), particularly human rights and health and safety risks. As for the ranking scores, differences decrease to 1.8 points because only human rights resulted relevant.

\subsubsection{Environmental Pillar}

Following the same structure than in the previous sections, Table 5.4 shows the environmental impacts results. 
Table 5.4 Environmental impacts for FISA results, ASE points and averaged weighted and ranking points for STE and NGCC

\begin{tabular}{|c|c|c|c|c|c|c|c|c|c|c|}
\hline & $\begin{array}{c}\text { STE } \\
\text { FISA } \\
(\%)\end{array}$ & $\begin{array}{c}\text { NGCC } \\
\text { FISA } \\
(\%)\end{array}$ & $\begin{array}{c}\text { STE } \\
\text { ASE } \\
\text { points }\end{array}$ & $\begin{array}{l}\text { NGCC } \\
\text { ASE } \\
\text { points }\end{array}$ & $\begin{array}{l}\text { Aver. } \\
\text { Weight } \\
\text { s score }\end{array}$ & $\begin{array}{c}\text { STE } \\
\text { Weighte } \\
\text { d points }\end{array}$ & $\begin{array}{c}\text { NGCC } \\
\text { Weighed } \\
\text { points }\end{array}$ & $\begin{array}{c}\text { Aver } \\
\text {. } \\
\text { Rank } \\
\text { score }\end{array}$ & $\begin{array}{c}\text { STE } \\
\text { Rank } \\
\text { points }\end{array}$ & $\begin{array}{c}\text { NGCC } \\
\text { Rank } \\
\text { points }\end{array}$ \\
\hline $\begin{array}{l}\text { Water } \\
\text { consum.* }\end{array}$ & 88 & 100 & -8.8 & -10.0 & 0.78 & -6.88 & -7.85 & 0.76 & -6.67 & -7.60 \\
\hline $\begin{array}{l}\text { Energy } \\
\text { consum. }\end{array}$ & 0.2 & 100 & -0.2 & -10.0 & 0.71 & -0.15 & -7.08 & 0.36 & -0.07 & -3.60 \\
\hline $\begin{array}{l}\text { Climate } \\
\text { Change }\end{array}$ & 0.2 & 100 & -0.2 & -10.0 & 0.78 & -0.18 & -7.85 & 0.80 & -0.18 & -8.00 \\
\hline $\begin{array}{l}\text { Photoch.oxid. } \\
\text { formation }\end{array}$ & 0.4 & 100 & -0.4 & -10.0 & 0.89 & -0.33 & -8.92 & 0.92 & -0.34 & -9.20 \\
\hline $\begin{array}{l}\text { Threatened } \\
\text { species }\end{array}$ & 0.4 & 100 & -0.4 & -10.0 & 0.82 & -0.30 & -8.15 & 0.48 & -0.18 & -4.80 \\
\hline Total & - & - & -9.9 & -50.0 & 0.78 & -7.8 & -39.8 & - & -7.4 & -33.2 \\
\hline
\end{tabular}

Source: Own elaboration

As displayed in Table 5.4, NGCC gets a worse score in all environmental impacts categories, with a difference of 40.1 points. When incorporating weights, this difference decreases to 32 points, because all considered indicators have a high to very high relevance for decision makers. Finally, when considering the ranking scores, the difference decreases to 25.8 because neither energy consumption nor threatened species resulted chiefly prioritized by majority.

\subsubsection{Sustainability Assessment}

Based on the figures presented above, Figure 3 displays differences on points achieved between technologies in each sustainability pillar regarding ASE, weighted and ranking scores. 


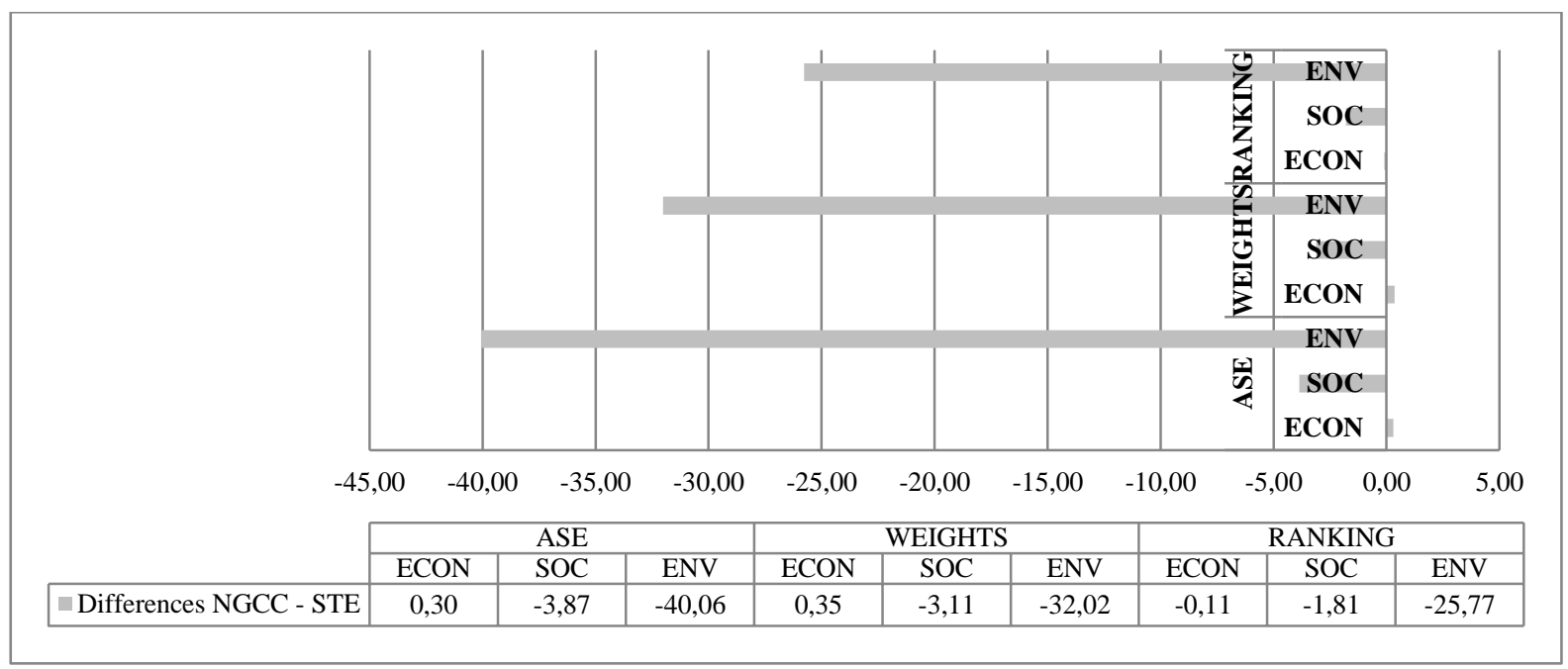

Figure 5.3 Differences between NGCC and STE scores in each pillar regarding the three different assessments. Source: Own elaboration

Figure 5.3 shows the difference in points obtained by the two technologies. NGCC has larger negative scores in all pillars and assessments with the exception of economic pillar in the ASE and weighted assessments. Greater differences exist in the environmental pillar for all types of assessments. As expected, both technologies achieve the lowest scores in the ranking assessment as decision makers have limited score to distribute.

Finally, taking into account the three sustainability pillars, total points scored are displayed in Figure 5.4.

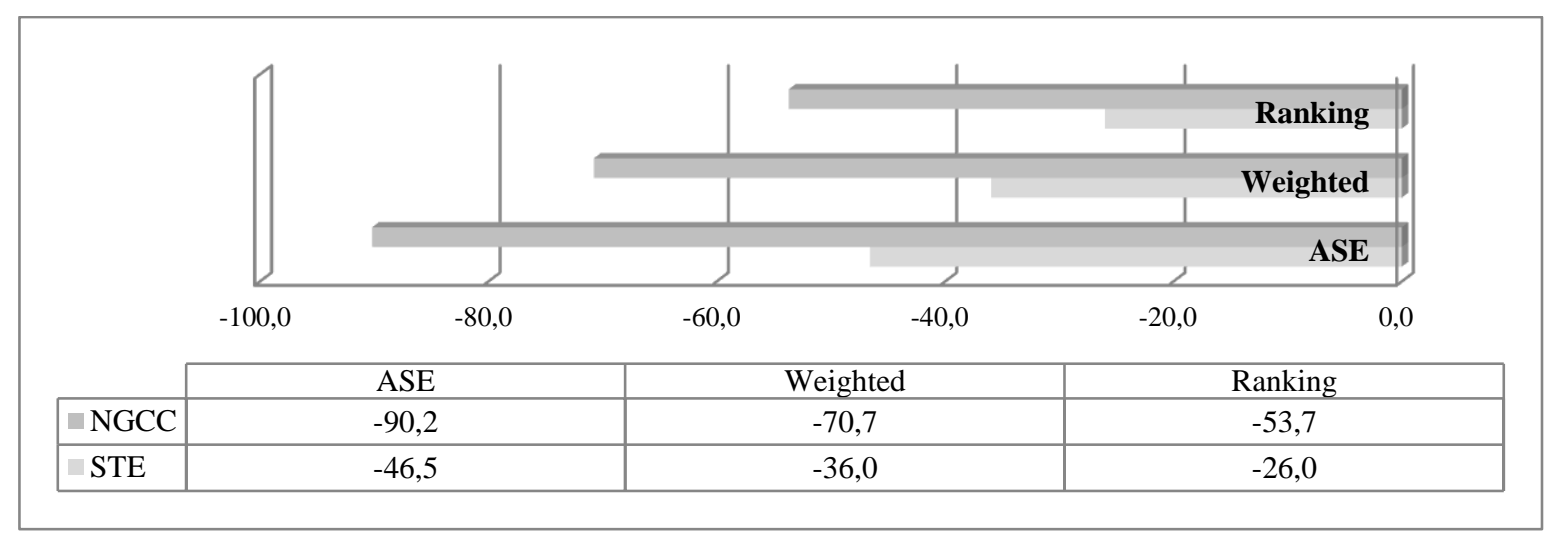

Figure 5.4 Total points achieved for each assessment for STE and NGCC. Source: Own elaboration 
Figure 5.4 shows negative aggregated sustainability points for both technologies in all considered assessments, but negative scores obtained by NGCC are much larger mainly from greater negative environmental results.

Final differences between technologies accounting for the three pillars are displayed in Figure 5.5, which shows the ratio of worse score achieved by NGCC from STE in each type of assessment.

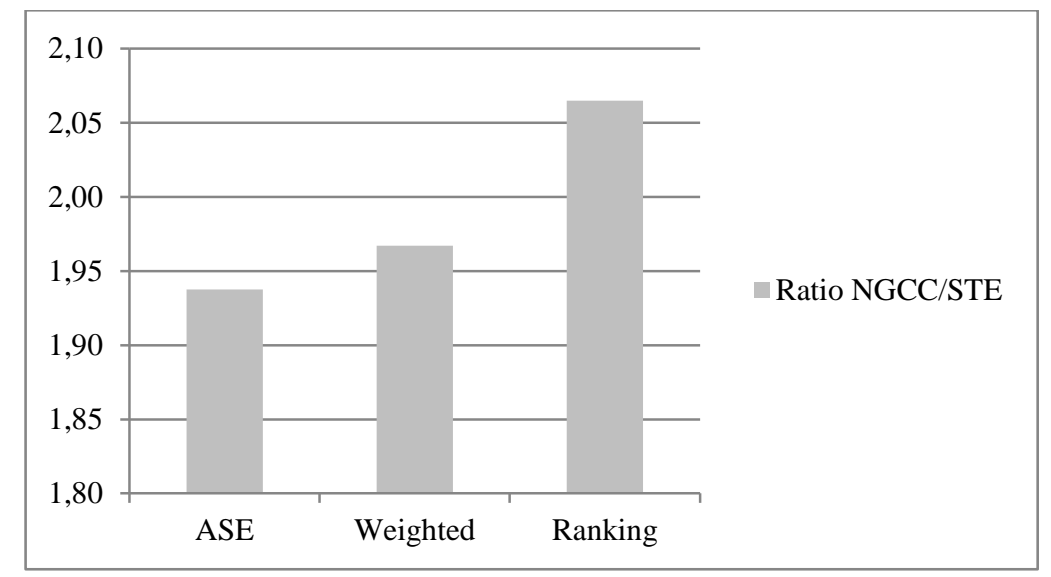

Figure 5.5 Ratio of worse score achieve by NGCC from STE in each type of assessment. Source: Own elaboration

Starting from ASE points, NGCC achieves a score 1.94 times worse than STE. When taking into account weights, this ratio increases to 1.97 because all impacts are important to decision makers (with the exception of working hours); and some environmental and social risks, where NGCC shows greater negative impacts, are particularly relevant to stakeholders. When accounting for ranking points, this ratio increases to 2.06 because decision makers mainly prioritize in five criteria where NGCC has larger negative impacts: human rights risks, photochemical oxidants creation, climate change potential, water consumption and project costs.

These differences on preferences are displayed in Figure 5.6, which summarizes the impacts' relevance from the weighted and ranking assessments (expressed in percentages of votes). Additionally, these results can be compared to those from FISA assessment, expressed in percentage of differences of each impact between NGCC and STE. 


\begin{tabular}{|c|c|c|c|}
\hline Impacts assessed & $\begin{array}{l}\text { FISA differences } \\
\text { NGCC-STE }\end{array}$ & $\begin{array}{l}\text { Weighted } \\
\text { priorities }\end{array}$ & $\begin{array}{l}\text { Ranking } \\
\text { priorities }\end{array}$ \\
\hline Project costs & $9 \%$ & $72 \%$ & $68 \%$ \\
\hline Added Value creation & $-2 \%$ & $75 \%$ & $44 \%$ \\
\hline Employments & $12 \%$ & $72 \%$ & $40 \%$ \\
\hline Working hours & $8 \%$ & $57 \%$ & $0 \%$ \\
\hline Wages & $9 \%$ & $74 \%$ & $8 \%$ \\
\hline Labor risks & $5 \%$ & $75 \%$ & $44 \%$ \\
\hline Health and safety risks & $8 \%$ & $\mathbf{8 8 \%}$ & $48 \%$ \\
\hline Human rights risks & $9 \%$ & $88 \%$ & $92 \%$ \\
\hline Governance risks & $8 \%$ & $74 \%$ & $20 \%$ \\
\hline Infrastructures risks & $8 \%$ & $7 \$ \%$ & $24 \%$ \\
\hline Water consumption & $12 \%$ & $78 \%$ & $7 \% \%$ \\
\hline Energy consumption & $\mathbf{9 8 \%}$ & $71 \%$ & $36 \%$ \\
\hline Climate Change potential & $98 \%$ & $78 \%$ & $80 \%$ \\
\hline Photochemical oxidants creation & $96 \%$ & $89 \%$ & $92 \%$ \\
\hline Affection to threatened species & $96 \%$ & $82 \%$ & $48 \%$ \\
\hline
\end{tabular}

Figure 5.6 Priorities obtained from FISA, weighting and ranking assessments. Source:

Own elaboration

As shown in third column of Figure 5.6 (ranking priorities), the main criteria selected from the raking assessment (highlighted in bold) correspond to impacts where NGCC have larger negative impacts. Additionally, most of these main criteria (photochemical oxidants creation, human rights risks and climate change potential) achieve larger relevance in the ranking assessment than in the weighted assessment.

To summarize Figure 5.6, FISA results indicate that much attention should be given to environmental effects. From the weighted assessment, it can be concluded that, with the exception of working hours, all impacts are considered relevant and particularly health and safety risks, human rights, photochemical oxidants creation and affection to threatened species. As for the ranking assessment, human rights risks and photochemical oxidants creation are particularly relevant; and to a lesser extent, climate change, water consumption and project costs.

Similarly to FISA charts, such results from the three assessments are simultaneously displayed in Figure 5.7. 


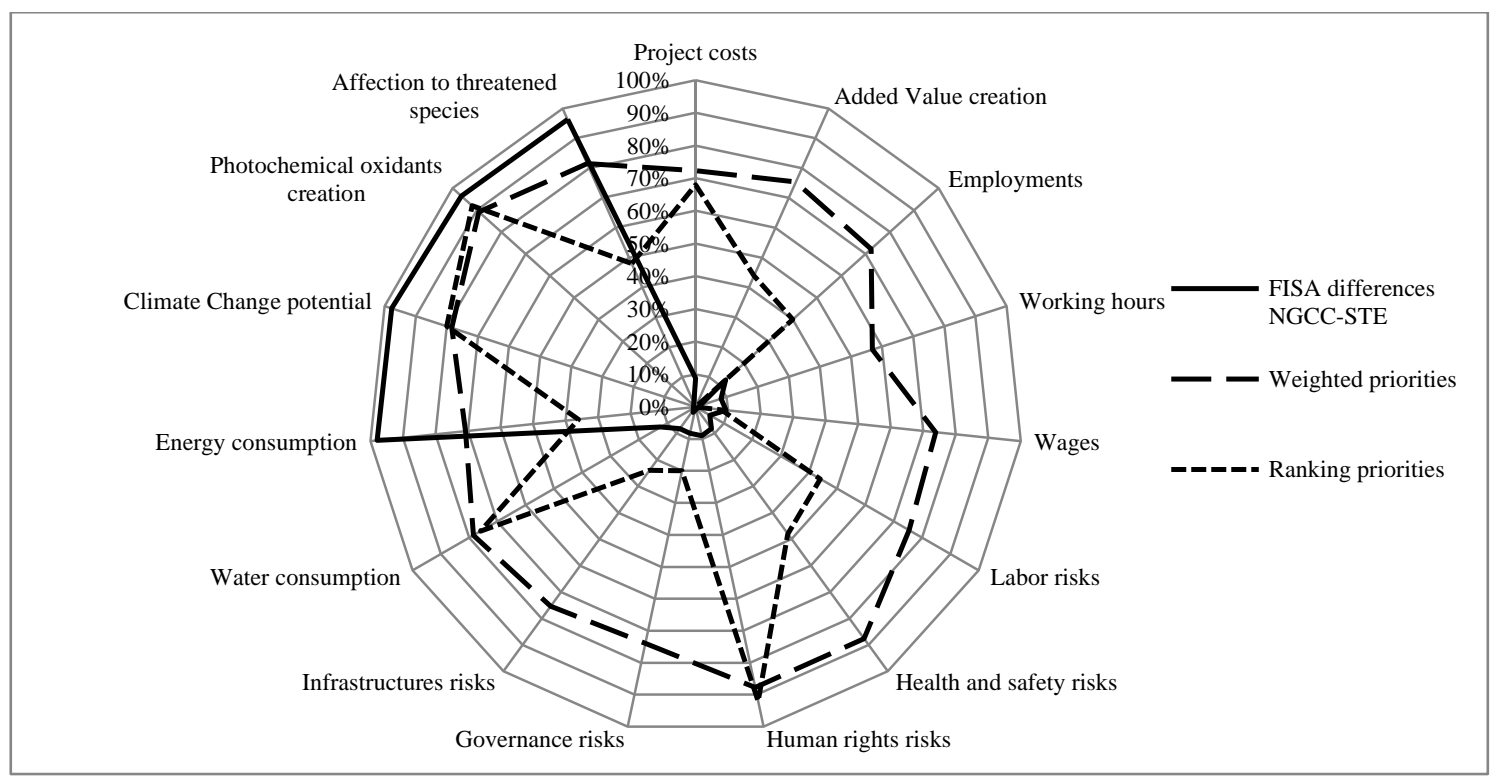

Figure 5.7 Comparison among FISA results, weighted preferences and ranking preferences

\subsection{Conclusion}

In this work, the FISA framework has been applied to support the electricity generation investment choice decision from alternative STE and NGCC technologies in Mexico. Results show that NGCC performs twice worse than STE, mainly from the environmental pillar. Additionally, it can be said that Mexican decision makers consulted for the study do not disregard any pillar when taking decisions but consider of especial relevance environmental impacts (photochemical oxidants creation) and social risks related to human rights. Moreover, it has been explored how forcing decision makers to prioritize and select a limited amount of impacts might change their final choice.

As for future lines of research, this work will be expanded by not only considering a larger number of stakeholders but also different stakeholder types (government officials, researchers, civil society, private sector representatives, etc.). Additionally, it is expected that the FISA framework will be improved (e.g.: by increasing the number of impacts considered) based on stakeholders' feedback on relevant or missing sustainability criteria. 


\section{Acknowledgments}

Author would like to thank all experts consulted and the support from the Unit of Informatics Systems at Ciemat. 


\section{Synthesis and future research}

\subsection{Main conclusions and research contributions}

The research objectives of this thesis were motivated by the current interest in sustainability studies which aim at considering and analyzing the economic, environmental and social implications of any activity or project. One of the most frequent weaknesses found in the sustainability assessment literature is the lack of integration of the three pillars and the lesser rigor paid to the social dimension compared to the economic and environmental ones. Additionally, in an increasing global world, another methodological challenge is the need to account for the whole supply chain of the production of goods and services, particularly in developing countries which often have weaker environmental and social protection laws enforcement.

The proposed Framework for Integrated Sustainability Assessment (FISA) was presented in Chapter 2 as a framework capable of analyzing, in an integrative way, the impacts across the three sustainability pillars occurring along the supply chain of any product or service. Based on the Multi Regional Input Output (MRIO) methodology, which traditionally assessed the socioeconomic and environmental impacts of different economic activities (Lenzen 1998; Wiedmann et al. 2007), one of the added values of the proposed FISA framework is the integration of the social dimension to the analysis by accounting for the potential social risks that could arise in the economic sectors stimulated by the studied projects. Finally, the resulting socioeconomic, environmental and social impacts of a specific project are equally displayed in the FISA outputs, which could help decision makers and companies in diagnosing the sustainability performance of the studied products and services, compare between different alternatives, and also derive recommendations as to how to reduce the harmful effects and increase the positive ones.

To test the validity and usefulness of FISA, the framework has been applied in Chapters 3, 4 and 5 to analyze alternative energy projects in Mexico in different case studies. Among other types of projects, energy investments are particularly interesting case studies in middle-income countries where decision makers must choose among different energy technology options with different sustainability performances in order 
to satisfy the growing energy demand. In this sense, Chapter 3 presented an assessment of the sustainability impacts along the supply chain of electricity generated from Solar Thermal Electricity (STE) in Mexico, considering the imported components and services in both the investment and operational phases. Chapter 4 focused on the comparison of the results from the STE impact assessment with those resulting from the same electricity generated by a fossil fuel technology, specifically Natural Gas Combined Cycle. Next, the relevance and usefulness of FISA impacts have been evaluated in Chapter 5 through a questionnaire to Mexican decision makers familiar with the energy sector.

Once a summary of each chapter was presented, this section presents the specific answers to the research questions formulated in the Introduction section.

Chapter 2: Framework for Integrated Sustainability Assessment (FISA): Methodological steps

RQ1. Given the cost data of any investment project, is the proposed Framework for Integrated Sustainability Assessment (FISA) able to account for its associated impacts within the three pillars of sustainability?

Every decision making process related to the implementation of a project or production of any good or service should analyze not only the associated costs and economic, benefits but also the environmental consequences and social implications in an equally way. To accomplish this objective, the Framework for Integrated Sustainability Assessment (FISA) is proposed in this thesis as an integration of two existing methodologies capable to assess the impacts of any economic activity in the three sustainability dimensions. Based on cost data of the different project phases along the supply chain, the Multiregional Input Output (MRIO) methodology allows to consider the associated environmental and socioeconomic effects taking place in the different economic sectors and countries included in the World Input Output Database (WIOD). Then, the FISA framework integrates the social dimension by taking into account a wide variety of social risks associated to the economic sectors included in the Social Hotspot Database (SHDB). Social risks refer to different social threats existing in the sectors classified in five impact categories: labor rights, human rights, health and safety, 
governance and community infrastructures. The social risks are represented by four risk values: low risk (1), medium risk (2), high risk (3) or very high risk (4). The risks values are obtained by different transformation processes of social indicators, for example characterizations based on data distribution (e.g.,. quartiles) or experts' consultation when indicators have a qualitative nature (GreenDelta 2013; New Earth 2013b). These social risks are adapted to the WIOD economic sectors and countries, which permits connecting MRIO results with the social risk values through the proposed Project Social Index (PSI). PSI figures integrate the socioeconomic stimulation caused by the analyzed project in terms of working hours with the social risks figures existing in those economic sectors. Sectors with higher PSI values are identified as Project Social Hotspots (PSH), which result in larger work forces but also contain high social risks that should be monitored. Finally, FISA outputs combine both the socioeconomic and environmental results and the PSI social figures to display which sustainability effects are causing the largest benefits but also the harmful consequences in all the countries involved. The identified sustainability hotspots could help to derive recommendations aimed at minimizing the negative effects of a project or when various alternatives are presented, to guide decision makers towards the choice of the best sustainable project, product or service.

RQ.2. Is FISA able to account for the sustainability impacts of any goods and services in any country by taking into consideration the international trade embedded throughout the whole supply chain?

When a product or service is offered in a specific country, probably some of the inputs needed to obtain the final product are imported from other countries where the resources are more abundant or where the environmental and social protection laws are weaker. In this sense, when assessing the impacts of any product or service, the whole chain should be accounted for to assess the direct effects, which are the ones related to the direct inputs needed in the value chain. Additionally, such direct activities in turn need for other inputs for their development, which are related to indirect relationships among the different sectors and countries, taking place the indirect effects. These indirect effects usually represent a relevant share of the total impact figures and due to the current globalization, most of the indirect effects may take place outside national borders. The 
quantification of both direct effects along the supply chain but also indirect effects from countries' trade is one of the objectives of the FISA framework, which affords an analysis not only of the real magnitude of the sustainability impacts but also the location where they take place.

Direct effects along the supply chain are estimated in the FISA framework by assigning the monetary value of imported components and services to the corresponding economic sectors and countries in the demand vector. In the case of the indirect effects from globalized trade, they are calculated through Leontief's equation in the MRIO analysis, using the Multiregional Input Output Table of the World Input Output Databased (WIOD), which includes 35 economic sectors and 40 countries plus a Rest of the World (RoW) region. Finally, the addition of direct and indirect effects are the total effects, which can be equally assessed in the three sustainability dimensions thanks to the socioeconomic and environmental accounts available in the WIOD and the Social Hotspot Database adapted to the same WIOD sectorial classification.

\section{RQ.3. How can FISA outputs/results support decisions making processes?}

FISA could be of special support for decision making processes because it provides information on the direct and indirect impacts of any product and service across multiple economic sectors and countries on the three sustainability dimensions. This diagnostic informs about the whole sustainability performance of the supply chain of projects. This could be of special support when analyzing the sustainability impacts a project to identify and foster the positive effects but also to identify and minimize of harmful ones. Furthermore, it could be especially useful when comparing effects of different alternatives in order to finally select the best project in a sustainability point of view.

Chapter 3: Application of FISA to Solar Thermal Electricity (STE) production in $\underline{\text { Mexico }}$

RQ.4. Which are the most relevant socioeconomic, environmental and social effects involved in the whole supply chain of STE production in Mexico? 
In the socioeconomic pillar, the largest effects are related to direct effects occurring in Mexico during the investment phase, with the exception of income generation, regarding that larger wages take place outside as a result of indirect effects. Regarding social impacts, larger PSI values correspond to direct effects occurring in Mexico also in the investment phase. Finally, most of the environmental impacts are caused by indirect effects during the investment phase outside Mexico.

RQ5. Which sectors and countries are more stimulated within each sustainability pillar?

As for the socioeconomic pillar, the Mexican financial sector is the most stimulated sector in all impact categories with the exception of job creation and working hours, which are most stimulated in the renting of machinery and other business activities sector. In terms of wages, results show larger figures outside Mexico. This is particularly relevant when comparing wages in Mexico and the USA, reflecting the existing wage disparities between the two countries. Although this mentioned Mexican sector has a large work force, wages are not created in the same magnitude. On the contrary, some North American sectors like the electrical and optical equipment show lower figures of employment creation and working hours but larger incomes generated, which reflects better quality of employments in the USA. With regards to the environmental pillar, the electricity sector in Mexico has the largest energy consumption, whereas in the climate change and photochemical oxidants categories, the nonmetallic mineral sector has largest impacts. Both the electricity and the nonmetallic mineral sectors have similar contribution in the acidification category. When looking at water consumption, the metal sector in Mexico has the largest figures. In the case of the threatened species category, the largest responsible is the electricity sector in Mexico, followed by the same Chinese from indirect effects. Finally, the most relevant sectors for the social pillar identified as Project Social Hotspots are the renting of machinery and other business activities sector in the first place, which show larger working hours figures and high social risks values, followed by the financial sector in the second place and the construction sector in the third place, all of them in Mexico.

RQ6. Are the results comparable to similar case studies from the literature? 
Results have been compared with similar STE impact assessment case studies. Socioeconomic results are comparable to the ones obtained by Caldés et al (2009). Environmental results are consistent with the reviewed studies: (Lechón et al. 2008; De la Rúa Lope 2009; Burkhardt et al. 2011, 2012; Corona et al. 2016). Most of these studies used the Environmental Life Cycle Assessment (ELCA) methodology. It is expected that the environmental figures of the present work are larger since MRIO does not establish systems boundaries. In the case of the social pillar, as the obtained PSI values cannot be compared with any previous published study, resulting risks identified within the Project Social Hotspots have been contrasted with reports from organizations such as "Understanding Children's Work", "Centro Mario Molina" or with the "Air Quality Index", and literature review in Hibler, (2003); Ostro, (2004); Heidelberg Institute for International Conflict Research, (2015) and Cingranelli and Richards, (2010). Such reports confirm the existence of the harmful social risks identified in the PSH.

RQ7: What recommendations can be derived from the results in order to improve the sustainability performance of STE in Mexico?

Results show that STE would stimulate Mexican production of goods and services, as well as added value and employment creation. In this sense, the deployment of the STE would stimulate the Mexican economy. However, this deployment would be accompanied by some negative effects that should be taken into account. First, working conditions should be monitored as results on employment creation in Mexico correspond to large working hours shares but low wages, especially in the investment phase. Second, there are high social risks directly involved in the supply chain of the manufacturing of goods and services that should be equally monitored, especially in the renting of machinery and other business activities sector and in the financial sector. Thus, it is recommended that the project suppliers comply with social regulations and standards and have good corporate social responsibility practices, especially in the mentioned hotspot sectors. Finally, it is also recommended that the environmental regulations and protection laws should be complied or even tightened, taking into consideration the direct impacts during the investment phase but also the derived indirect effects occurring in Mexico along the supply chain. 
Chapter 4: Comparison of STE production and Natural Gas Combined Cycle electricity production in Mexico with FISA

RQ8. What are the main differences between the sustainability performance of the STE compared to the Natural Gas Combined cycle electricity production?

For the socioeconomic pillar, STE shows a 15\% larger positive impact in added value creation and also better employment conditions as its shows $20 \%$ larger wages and $2 \%$ lower working hours. Regarding the social pillar, there are similar social risks involved from both technologies but they could be easier to identify and tackle in the case of STE, as they result mostly from direct activities involved while NGCC results from indirect effects. Finally, it is in the environmental pillar where larger differences exist between technologies as NGCC shows between 94-96\% worse impact figures than STE.

RQ9. When comparing technologies, which sectors and countries are more stimulated in each sustainability pillar?

In the socioeconomic dimension, whereas STE mostly stimulates the financial and the renting of machinery and other business sectors in Mexico, NGCC mostly stimulates the electricity, gas and water supply Mexican sector. With regards to the environmental pillar; the electricity, gas and water supply Mexican sector is responsible for the largest impacts for NGCC in all categories (with more than $90 \%$ contribution) and for STE in most of the impact categories but with significantly lower contribution (around 15\%). Regarding the social pillar, while the top PSH from NGCC electricity production corresponds to the "electricity, gas and water supply" Mexican sector, for STE it corresponds to the Mexican "renting of machinery and other business activities".

RQ10. What energy policy recommendations can be derived from the comparative assessment?

Results show that the associated socioeconomic impacts of NGCC and STE are of similar magnitude, but STE would create higher added value and generate better quality employment. Regarding social concerns, similar social risks are involved in both supply chains but they are easier to identify for STE as main risks are involved in direct 
activities, so measures should be put in place for suppliers with poor social responsibility practices. As for the environmental effects, NGCC impacts are remarkably worse than STE, mainly as a result of the natural gas used during the operational phase. Having in mind all these concerns, it is shown that the deployment of STE in Mexico would have larger socioeconomic benefits than NGCC; similar social risks but easier to identify and implement solutions; and much better environmental performance.

\section{Chapter 5: Accounting for decision makers' priorities in Mexico}

RQ11. Which are the stakeholders' revealed preferences about sustainability criteria considered in FISA?

Stakeholders' revealed preferences indicate that all FISA impacts are considered relevant, particularly photochemical oxidants creation and the violation of human rights. The only impact that they do not consider relevant is the number of working hours.

RQ12. Which technology achieves the poorest sustainability score?

NGCC achieves the poorest Aggregated Sustainability Endpoints score mostly due to the larger negative effects in the environmental dimension. NGCC electricity production results about two times worse than STE, especially when taking into account stakeholders' preferences as some environmental and social risks where NGCC achieves greater negative impacts are particularly relevant to stakeholders.

RQ13. Have interviewees changed their opinion about relevant sustainability criteria after seeing FISA impacts?

The stakeholder consultation results revealed that $75 \%$ of the respondents did not account for some of the FISA impacts in previous decisions but they will do in future decision making processes. 
RQ14. Have interviewees suggested other criterions to be included in the FISA framework?

Mexican decision makers suggest other relevant criterions that should be taken into account when installing any type of electricity generation systems. First, it should be possible to establish a grid connection to the network. Considering that the FISA framework does not have any indicator for such objective, the hypothetic location for the STE plant near Hermosillo city has been selected due to the availability of grid integration according to the European Solar Thermal Energy association ESTELA. Another issue that concerns decision makers is related to the risk of the intermittence of solar electricity generation, for example at night or in fogy days. This is one of the concerns presented at the beginning of the study, which made us consider the STE plant with an energy storage capacity according to ESTELA. This is one of the advantages of STE as this renewable technology allows the integration of energy storage systems. Furthermore, some of the interviewees suggested the possibility of cogeneration and this could be a good option for STE plants without energy storage systems. Additionally, most of the interviewees expressed their desire of using national resources in terms of personnel and local manufactured components. In this sense, more training for local personnel is needed, mainly for engineering activities and maintenance of the plant. Concerning the local content of components, a further deployment of STE in Mexico should be expected, so that local companies achieve the expertise to fabricate STE components and progressively reduce imported components. Moreover, stakeholders indicate that the project should have political viability and compliance with national targets. In the case of STE, as a renewable energy, it is in line with the National Law of Climate Change ${ }^{12}$ and further policies related to the progressively decarbonization of the Mexican energy mix. Finally, some of the interviewees warned against about possible corruption involved in the STE supply chain market. This is one of the concerns that could be monitored with the FISA framework by looking for the existence of social risks within the "Governance" impact category along the whole STE supply chain.

\footnotetext{
${ }^{12}$ Ley General de Cambio Climático (published 06/06/2012): http://www.inecc.gob.mx/descargas/2012_lgcc.pdf
} 


\subsection{Limitations and future research lines}

The FISA framework aimed at conducting a sustainability assessment of the impacts involved in the supply chain of goods and services and main advantages derived from the analysis have been mentioned in previous sections. Nevertheless, the framework is not exempt from the limitations of the underlying methodologies and their combination in the framework. One of the main limitations is related to the sectorial aggregation involved in the Input Output assessment, which assumes the same nature of socioeconomic and environmental impacts in a given sector (Leontief 1955). With the integration of the social pillar in the FISA framework, such limitation also applies to the social dimension because social risks are assumed to be homogeneous within all activities and industries aggregated in the same sector. Furthermore, this assumption does not take into account that companies may have different social responsibility practices within a given sector (Rodríguez-Serrano et al. 2016b). Another limitation related to the MRIO analysis is the underestimation of results as the informal transactions in the economy cannot be accounted for (Holland and Cooke 1992), which leads to poorer economic stimulation results from the project and consequently underestimations of the different impacts obtained in the extended IO analysis. The integration of the social dimension is also affected by this limitation as companies behind these informal activities may face lesser obstacles for the noncompliance of regulations, which could give rise to higher social risks exiting in economic sectors. Furthermore, some important social issues could not be accounted for in the analysis because they are not appropriately covered by indicators in the SHDB.

Additionally, uncertainties related to the main databases, WIOD and SHDB, should be taken into account. First, the construction of the MRIOT is based on the combination of national statistics with bilateral trade statistics, which lead to resulting discrepancies among the sectorial GDP figures reported by national accounts and the multiregional database (Jones et al. 2014). Second, the construction of the SHDB is based on the collection of quantitative indicators, with the associated uncertainties related to its construction, and also qualitative information data, which is not exempt of some level of subjectivity (UNEP et al. 2009). Moreover, the transformation of the qualitative data into quantitative social risks values cannot be achieved by traditional 
quantitative processes (e.g. distribution of data in quartiles), and other methods have to be used, such as experts' consultation, which is not as transparent and objective as traditional quantitative methods (Carraro et al. 2013).

Concerning the datasets supporting FISA, its related limitations should be also taken into account as this could significantly affect the results. The periodicity of publication of the MRIO datasets (MRIOT and socioeconomic and environmental accounts) is a main constraint as they are not published nor updated every year (Suh and Huppes 2002; Suh and Nakamura 2007; Kjaer et al. 2015). In the same way, social indicators used for the calculation of social risks within the SHDB are not updated, and even these risk figures, more obsolete regarding that quantitative social indicators, are published with less frequency and qualitative data is usually difficult to update as its collection requires time and efforts (e.g. interviews, field visits, etc.). Moreover, the SHDB lacks risk values in some sectors and countries (Franze 2013), and in the case of the WIOD classification, there is data lack of social risks for the following countries: Russia, Ireland and United Kingdom).

Furthermore, it is important to note the limitations associated to the influence of the data and working assumptions to the results as their variations could substantially affect the results. For example, results could significantly change when varying the local content shares or cost assumptions of technologies.

Finally, the number and type of consulted stakeholders in the questionnaire determine the final sustainability scores obtained, for example depending on the number of participants related to the academic field, private sector, local communities or representatives of society as NGOs, among others.

These identified limitations also facilitate the identification of the new research paths. Future research lines will be focused on the improvement of the methodological framework by considering other impacts (for example land use) and especially the ones relevant for affected stakeholders; as well as exploring the hybridization with other methodologies to solve limitations (e.g. with Life Cycle Analysis to minimize sectorial aggregation errors).

Regarding the FISA application, given the sensitivity of results, variations of key selected variables are envisaged in a future research, such as in technology costs, local content, interest rates or discount rates, among others). Additionally, further case studies 
analyzing STE production should be developed in other countries to compare the sustainability performance of STE projects in different locations. In the same way, other renewable energy technologies should be assessed in Mexico to explore the different options for the deployment of local renewable energies and their associated sustainability impacts. Moreover, FISA usefulness for stakeholders should be further analyzed by considering more categories of stakeholders in the survey, like representatives of the civil society, private sector and nonprofits organizations, as well as increase the number of participants in each category. Finally, based on the FISA results, it would be interesting to further develop policy recommendations to support decision making processes related to the improvement of the sustainability performance of the analyzed case studies and guide them to the identification of the best alternatives which mostly contribute to a sustainable development. 


\section{References}

Adams W. The future of sustainability. Futur Sustain. 2006;(January):1-257.

Air Quality Index. World Air Quality Index [Internet]. 2016 [cited 2016 Jan 1]. Available from: http://aqicn.org/city/mexico/mexico/camarones/

Alsamawi A, Murray J, Lenzen M. The employment footprints of nations: Uncovering master-servant relationships. J Ind Ecol. 2014;18(1):59-70.

Álvarez S. Huella de carbono de organización y producto con enfoque híbrido: mejoras en el método compuesto de las cuentas contables. Universidad Politécnica de Madrid; 2014.

Andrew R, Peters G., Lennox J. Approximation and regional aggregation in multiregional input-output analysis for national carbon footprint accounting. 2009 [cited 2015 Aug 31]; Available from: http://www.tandfonline.com/doi/pdf/10.1080/09535310903541751\#.VeRFeiXtmk $\mathrm{p}$

Arancibia-Bulnes CA, Peón-Anaya R, Riveros-Rosas D, Quiñones JJ, Cabanillas RE, Estrada CA. Beam solar irradiation assessment for Sonora, Mexico. Energy Procedia [Internet]. 2014;49:2290-6. Available from: http://dx.doi.org/10.1016/j.egypro.2014.03.242

Archer B, Fletcher J. The economic impact of tourism in the Seychelles. Ann Tour Res. 1996;23(1):32-47.

Arto I, Rueda-Cantuche JM, Peters GP. Comparing the Gtap-Mrio and Wiod Databases for Carbon Footprint Analysis. Econ Syst Res [Internet]. 2014;26(3):327-53. Available from: http://www.tandfonline.com/doi/abs/10.1080/09535314.2014.939949 
Barboza-Carrasco I, Vázquez-Alvarado J, Matus-Gardea J. Matriz de contabilidad social 2004 para méxico. Agrociencia. 2009;(43):551-8.

Barrett J, Peters G, Wiedmann T, Scott K, Lenzen M, Roelich K, et al. Consumptionbased GHG emission accounting: a UK case study. Clim Policy [Internet]. 2013;13(4):451-70. Available from: http://dx.doi.org/10.1080/14693062.2013.788858\%5Cnhttp://www.tandfonline.co m/doi/abs/10.1080/14693062.2013.788858

Battelle. Natural Gas-Fired Combined-Cycle Power Plant Alternative for the Railbelt Region of Alaska. Vol. XIII. Alaska; 1982.

Baumol WJ, Wolff EN. A key role for input-output analysis in policy design. Reg Sci Urban Econ [Internet]. 1994 Feb [cited 2015 Aug 27];24(1):93-113. Available from: http://www.sciencedirect.com/science/article/pii/0166046294900213

Belke A, Dobnik F, Dreger C. Energy consumption and economic growth: New insights into the cointegration relationship. Energy Econ [Internet]. 2011;33(5):782-9. Available from: http://dx.doi.org/10.1016/j.eneco.2011.02.005

Benoît C, Aulisio D, Hallisey-kepka C, Tamblyn N, Norris GA. Social Scoping Prototype Strawberry Yogurt. Arizona; 2012.

Benoit C, Norris G, Valdivia S, Beck T. The Guidelines for Social Life Cycle Assessment of products : Just in time! Int J Life Cycle Assess. 2010;15(February 2011):156-63.

Benoit Norris C, Aulisio D, Norris G. Working with the Social Hotspot Database: methodology and findings from 7 social scoping assessments. 2012; Available from: http://www.springerlink.com/index/10.1007/978-3-642-29069-5

Bernow S, Marron D. Valuation of Environmental Externalities for Energy Planning 
and Operations [Internet]. Boston; 1990 [cited 2015 Sep 10]. Available from: https://books.google.es/books/about/Valuation_of_Environmental_Externalities.ht ml?id=0yfGtgAACAAJ\&pgis $=1$

Bezerr J. Evaluation of Two Competing Machining Processes Based on Sustainability Indicators. In: Leveraging Technology for a Sustainable World Proceedings of the 19th CIRP Conference on Life Cycle Engineering, University of California at Berkeley, Berkeley, USA, May 23 - 25, 2012. Sao Paulo; 2012.

Breitschopf B, Nathani C, Resch G. IEA-RETD project: "Economic and Industrial Development " EID - EMPLOY. Methodological guidelines for estimating the employment impacts of using renewable energies for electricity generation. Karlsruhe, Germany; 2012.

Burkhardt JJ 3rd, Heath GA, Turchi CS. Life cycle assessment of a parabolic trough concentrating solar power plant and the impacts of key design alternatives. Environ Sci Technol. 2011;45(6):2457-64.

Burkhardt JJ, Heath G, Cohen E. Life Cycle Greenhouse Gas Emissions of Trough and Tower Concentrating Solar Power Electricity Generation: Systematic Review and Harmonization. J Ind Ecol. 2012;16(SUPPL.1).

Cabal H, Lechón Y, Rodríguez A, Castrejón D, Flores MP. Effect of the energy and climate policies in the future Mexican electricity system. Abu Dhabi; 2015.

Caldés N, Coady D, Maluccio J a. The cost of poverty alleviation transfer programs: A comparative analysis of three programs in Latin America. World Dev. 2006;34(5 SPEC. ISS.):818-37.

Caldés N, Lechón Y. Análisis de externalidades de las energías renovables. In: Tratado de energías renovables [Internet]. Editorial Aranzadi; 2010 [cited 2015 Jun 30]. p. 
951-1004.

Available

from:

http://dialnet.unirioja.es/servlet/articulo?codigo=3187593

Caldés N, Varela M, Santamaría M, Sáez R. Economic impact of solar thermal electricity deployment in Spain. Energy Policy. 2009;37(5):1628-36.

Cardenete MA, Fuentes P. Análisis del sector energético español a través de un modelo de crecimiento sostenible. España: Fundación EIO; 2009.

Carraro C, Campagnolo L, Eboli F, Giove S, Lanzi E, Parrado R, et al. The FEEM Sustainability Index: An integrated Tool for Sustainability Assessment. 2013;16993. Available from: http://link.springer.com/10.1007/978-3-642-32081-1

Cartelle Barros JJ, Lara Coira M, de la Cruz López MP, del Caño Gochi A. Assessing the global sustainability of different electricity generation systems. Energy. 2015;89:473-89.

Casillas CE, Kammen DM. Quantifying the social equity of carbon mitigation strategies. Clim Policy. 2012;12(6):690-703.

Centro Mario Molina. Implications of air pollution on health in Mexico City's Metropolitan area and the potential benefits of applying control measures. Mexico DF; 2003.

CFE. Costos y Parámetros de Referencia para la Formulación de Proyectos de Inversión del Sector Eléctrico. COPAR 2012. Mexico; 2012.

Chhipi-Shrestha GK, Hewage K, Sadiq R. "Socializing” sustainability: a critical review on current development status of social life cycle impact assessment method. Clean Technol Environ Policy. 2015;17(3):579-96.

Cingranelli DL, Richards DL. The Cingranelli and Richards (CIRI) Human Rights Data Project. Hum Rights Quartely. 2010;32:395-418. 
Cohen A. The Multidimensional poverty assessment tool: User's guide. 2009;

Corona B, Rúa C de la, San Miguel G. Socio-economic and environmental effects of concentrated solar power in Spain: A multiregional input output analysis. Sol Energy Mater Sol Cells [Internet]. 2016a;(article i:1-10. Available from: http://linkinghub.elsevier.com/retrieve/pii/S0927024816001161

Corona B, Rúa C de la, San Miguel G. Socio-economic and environmental effects of concentrated solar power in Spain: A multiregional input output analysis. Sol Energy Mater Sol Cells [Internet]. 2016b;(April):1-10. Available from: http://linkinghub.elsevier.com/retrieve/pii/S0927024816001161

Dreger C. Energy Consumption and Economic Growth. 2010.

Dreyer LC, Hauschild MZ, Schierbeck J. A Framework for Social Life Cycle Impact Assessment. Int J [Internet]. 2006;11(2):88-97. Available from: http://www.springerlink.com/index/10.1065/lca2005.08.223

Duscha V, Ragwitz M, Breitschopt B, Schade W, Walz R, Pfaff M, et al. Employment and growth effects of sustainable energies in the European Union [Internet]. Germany; 2014. Available from: http://ec.europa.eu/energy/sites/ener/files/documents/EmployRES-II final report_0.pdf

Elkington J. Cannibals with Forks: The Triple Bottom Line of 21st Century Business [Internet]. 1998 [cited 2015 Jul 29]. Available from: https://books.google.es/books/about/Cannibals_with_Forks.html?id=SRNPAAAA MAAJ\&pgis $=1$

EORA. Global Multiregional Input Ouput Database - EORA Database [Internet]. 2016 [cited 2016 Mar 28]. Available from: http://worldmrio.com/ 
Erumban AA, Gouma R, De Vries G, De Vries K, Timmer M. WIOD SocioEconomic Accounts (SEA): Sources and Methods. 2012a.

Erumban A, Gouma R, De Vries G, De Vries K, Timmer M. Sources for National Supply and Use Table Input files [Internet]. Brussels; 2012b. Available from: message:\%3C419BAFC76E47574590C9345DD466654D041A04@ctspigdcapmxs 34.cihs.ad.gov.on.ca\%3E\%5Cnpapers2://publication/uuid/5B8B72E8-3C14-4C168501-D0CA5601957B

Esmaeili A, Shahsavari Z. Valuation of irrigation water in South-western Iran using a hedonic pricing model. Appl Water Sci. 2011;1(3-4):119-24.

ESTELA. Las centrales termosolares: Una gran oportunidad para México. Mexico DF; 2014.

ESTELA. STE competitiveness vs other renewables and conventional. Casablanca; 2016.

ETSU, METROECONOMICA. ExternE. Externalities of Energy. Methodology. 1995.

Feng K, Chapagainb A, Suhc S, Pfisterc S, Hubacek K. Comparison of bottom-up and top-down approaches to calculating the water footprints of nations. 2011 [cited 2015 Sep 10]; $\quad$ Available from: http://www.tandfonline.com/doi/pdf/10.1080/09535314.2011.638276

Ferroukhi R, Khalid A, Lopez-Peña A, Renner M. Renewable Energy and Jobs. Abu Dhabi; 2015.

Fichtner, The World Bank, ESMAP. Assessment of Technology Options for Development of Concentrating Solar Power in South Africa. Johannesburg, South Africa: Fichtner; 2010.

Foran B, Lenzen PM, Moran D. The Eora MRIO: A Complete Database of Flows in the 
World Economy The Dummies Guide [Internet]. Australia; 2011. Available from: http://worldmrio.com/EoraForDummies.pdf

Foster Associates. Cost of capital / rate of return study. US; 2006.

Franze J. Working with the Social Hotspots Database in openLCA. 2013;(April).

Friedman M. The Social Responsibility of Business Is to Increase Its Profi ts. In: New York Times Magazine. 1970. p. 17.

Gehlhar M. Reconciling Bilateral Trade Data for Use in GTAP. GTAP Tech Pap. 1996;Paper 10.

Genty A, Arto I, Neuwahl F. Final Database of Environmental Satellite Accounts: Technical Report on Their Compilation [Internet]. Vol. 4.6, WIOD Deliverable. 2012. Available from:

http://www.wiod.org/publications/source_docs/Environmental_Sources.pdf

Goedkoop M, Heijungs R, Huijbregts M, De Schryver A, Struijs J, Zelm R Van. ReCiPe 2008. A life cycle impact assessment method which comprises harmonised category indicators at the midpoint and the endpoint level. Netherlands; 2013.

Gouma R, Timmer M, De Vries G. Employment and Compensation in the WIOD Socio-Economic Accounts ( SEA ): Revisions for 2008/2009 and new data for 2010/2011. 2014.

Govender K, Hounsome R, Weaver A. SUSTAINABILITY ASSESSMENT: DRESSING UP SEA? - EXPERIENCES FROM SOUTH AFRICA. J Environ Assess Policy Manag. 2006;8(3):321-40.

Graymore MLM. Sustainability reporting: An approach to get the right mix of theory and practicality for local actors. Sustain. 2014;6(6):3145-70.

GreenDelta. Social Hotspot Database Introductory User Tutorial. York, Maine, USA: 
SHDB project; 2013.

Greenpeace, ESTELA, SolarPACES. Solar thermal electricity global outlook 2016. Executive summary. Abu Dhab; 2016.

GTAP. Chapter 12.B. Disaggregating Labor Payments [Internet]. GTAP 9 Data Base Documentation. Indiana: Purdue University; 2012. p. 17. Available from: www.gtap.agecon.purdue.edu/resources/res_display.asp?RecordID=4867

Guinée J. Taking Stock of Industrial Ecology. In: Life Cycle Sustainability Assessment: What Is It and What Are Its Challenges? 2015. p. 385.

Hacking T, Guthrie P. A framework for clarifying the meaning of Triple Bottom-Line, Integrated, and Sustainability Assessment. 2008;28:73-89.

Hamilton K. Scaling up Renewable Energy in Developing Countries: finance and investment perspectives. UK; 2010.

Hansmann R, Mieg HA, Frischknecht P. Principal sustainability components: empirical analysis of synergies between the three pillars of sustainability. Int J Sustain Dev world Ecol. 2012;19(5):451-9.

Harslett P. The GTAP Data Base Construction Procedure By GTAP Working Paper No .76. 2013.

Heidelberg Institute for International Conflict Research. Conflict Barometer 2015. Disputes, non-violent crises, violent crises, limited wars, wars. Germany; 2015.

Hendrickson C, Horvath a, Joshi S, Lave L. Economic input-output models for environmental life-cycle assessment. Environ Sci Technol. 1998;32(7):184a-191a.

Herman D. Beyond Growth: Economics of Sustainable Development: Amazon.es: Herman E. Daly: Libros en idiomas extranjeros [Internet]. 1997. Available from: https://www.amazon.es/Beyond-Growth-Economics-Sustainable- 
Development/dp/0807047090

Hertwich E, Peters G. Carbon footprint of nations: A global, trade-linked analysis. Environ Sci Technol [Internet]. 2009;43(16):6414-20. Available from: http://pubs.acs.org/doi/full/10.1021/es803496a

Hibler M. Taking Control of Air Pollution in Mexico City [Internet]. Ecosystem Approaches to Human Health Program Initiative. Canada; 2003. Available from: http://scholar.google.com/scholar?hl=en\&btnG=Search\&q=intitle:Taking+Control +of+Air+Pollution+in+Mexico+City\#0

Hinkley J, Curtin B, Hayward J, Csiro AW, Boyd R, Grima C, et al. Concentrating solar power - drivers and opportunities for cost-competitive electricity. Australia; 2011.

Hohmeyer O. Social Costs of Energy Consumption: External Effects of Electricity Generation in the Federal Republic of Germany [Internet]. Germany; 1988 [cited 2015 Sep 10]. Available from: https://books.google.com/books?hl=es\&lr=\&id=9VLuCAAAQBAJ\&pgis=1

Holland D, Cooke SC. Sources of structural change in the Washington economy. Ann Reg Sci [Internet]. 1992 Jun [cited 2015 Jun 30];26(2):155-70. Available from: http://link.springer.com/10.1007/BF02116367

Hong J, Xu C, Hong J, Tan X, Chen W. Life cycle assessment of sewage sludge coincineration in a coal-based power station. Waste Manag. 2013;

Huff K, McDougall R, Walmsley T. Contributing Input-Output Tables to the GTAP Data Base Contributing Input-Output Tables to the GTAP Data Base GTAP Technical Paper No . 1. GTAP Technical Papers. Guelph; 2000.

Hutchins MJ, Sutherland JW. The role of the social dimension in life cycle engineering. Int J Sustain Manuf. 2009;1(3):238-50. 
IISD. Seven Questions to Sustainability. How to Assess the Contribution of Mining and Minerals Activities. Canada; 2002.

INERE. Inventario Nacional de Energías Renovables [Internet]. 2015 [cited 2016 Mar 28]. Available from: http://inere.energia.gob.mx/version4.5/

Instituto Nacional de Estadística y Geografía. Exportación de petróleo crudo, series estadísticas 1965-2010 [Internet]. 2016 [cited 2016 May 18]. Available from: http://www.inegi.org.mx/sistemas/bie/default.aspx

International Energy Agency. World Energy Outlook 2015 Factsheet. Global energy trends to 2040:The energy sector and climate change in the run-up to COP21. 2015.

International Energy Agency, Nuclear Energy Agency. Projected Costs of Generating Electricity. Executive Summary. 2015.

Investing. Mexico 10-Year Bonds [Internet]. 2015 [cited 2016 Mar 28]. Available from: http://www.investing.com/rates-bonds/mexico-10-year-historical-data

IPCC. Working group I contribution to the IPCC fifth assessment report climate change 2013: the physical science basis. Stockholm; 2013.

IRENA. Renewable Power Generation Costs. 2015.

IRENA. Roadmap for a renewable energy future. Abu Dhabi; 2016.

IRENA, SENER. REmap 2030. Renewable Energy Prospects: Mexico. Abu Dhabi; 2015.

Isard W. Interregional and Regional Input-Output Analysis: A Model of a SpaceEconomy. 1951 [cited 2015 Sep 7]; Available from: http://www.jstor.org/stable/1926459?seq=1\#page_scan_tab_contents

IUCN. The IUCN Red List of Threatened Species [Internet]. 2015a [cited 2016 Mar 
28]. Available from: http://www.iucnredlist.org/

IUCN. Threatened species in each country (totals by taxonomic group). $2015 \mathrm{~b}$.

Jala, Nandagiri L. Evaluation of Economic Value of Pilikula Lake Using Travel Cost and Contingent Valuation Methods. Aquat Procedia [Internet]. 2015;4(Icwrcoe):1315-21. Available from: http://linkinghub.elsevier.com/retrieve/pii/S2214241X15001728

Jones L, Wang Z, Xin L, Degain C. The Similarities and Differences among Three Major Inter-Country Input-Output Databases and their Implications for Trade in ValueAdded Estimates. Washington; 2014.

Jørgensen A, Bocq A Le, Nazarkina L, Hauschild M. Societal LCA Methodologies for Social Life Cycle Assessment. Int J Life Cycle Assess. 2008;13(2):96-103.

Kajikawa Y. Research core and framework of sustainability science. Sustain Sci. $2008 ; 3(2): 215-39$.

Kannan R, Leong KC, Osman R, Ho HK. Life cycle energy, emissions and cost inventory of power generation technologies in Singapore. Renew Sustain Energy Rev. 2007;11(4):702-15.

Kjaer LL, Host-Madsen NK, Schmidt JH, McAloone TC. Application of environmental input-output analysis for corporate and product environmental footprints-learnings from three cases. Sustain. 2015;7(9):11438-61.

Kofoworola F, Gheewala S. An input-output analysis of Thailand's construction sector. 2008 [cited 2015 Aug 27]; Available from: http://www.tandfonline.com/doi/pdf/10.1080/01446190802425560\#.Vd7iK7Ltmk o

Kondo Y, Moriguchi Y, Shimizu H. CO2 emissions in Japan: influences of imports and 
exports. Appl Energy. 1998;59(2-3):163-74.

Korpi E, Ala-Risku T. Life cycle costing: a review of published case studies. Manag Audit J. 2008;23(3):240-61.

Kuitunen M, Jalava K, Hirvonen K. Testing the usability of the Rapid Impact Assessment Matrix (RIAM) method for comparison of EIA and SEA results. Environ Impact Assess Rev. 2008;28(4-5):312-20.

De la Rúa Lope C. Desarrollo de la herramienta integrada "análisis de ciclo de vida Input Outout análisis para España y aplicación a tecnologías energéticas avanzadas.” Documentos CIEMAT. Madrid, España: CIEMAT; 2009.

Lechón Y, de la Rúa C, Sáez R. Life Cycle Environmental Impacts of Electricity Production by Solarthermal Power Plants in Spain. J Sol Energy Eng. 2008;130(2):21012.

Lee. Integrated Approaches to Impact Assessment: Substance or Make Believe? In: Environmental Assessment Yearbook 2002. Manchester: Institute of Environmental Management and Assessment/EIA Centre; 2002. p. 14-20.

Lehman G. Disclosing new worlds: a role for social and environmental accounting and auditing. Accounting, Organ Soc. 1999;24(3):217-41.

Lenzen M. Primary energy and greenhouse gases embodied in Australian final consumption: an input-output analysis. Energy Policy. 1998;26(6):495-506.

Lenzen M, Moran D, Kanemoto K, Geschke A. Building EORA: A global MultiRegion Input-Output database at high country and sector resolution. Econ Syst Res [Internet]. 2013 Mar 21 [cited 2016 Mar 21];25(1):20-49. Available from: http://www.tandfonline.com/doi/abs/10.1080/09535314.2013.769938

Leontief W. Quantitative Input and Output Relations in the Economic Systems of the 
United States. Rev Econ Stat [Internet]. 1936 [cited 2015 Jun 30];18(3):105-25. Available

from: http://www.jstor.org/stable/1927837?seq=1\#page_scan_tab_contents

Leontief W. Some basic problems of empirical input-output analysis. In: Input-Output Analysis: An Appraisal. Princeton University Press; 1955. p. 9-52.

Lifset R. Toward Meta-Analysis in Life Cycle Assessment. J Ind Ecol. 2012;16:1-2.

Linke BS, Corman GJ, Dornfeld D a., Tönissen S. Sustainability indicators for discrete manufacturing processes applied to grinding technology. J Manuf Syst [Internet]. 2013;32(4):556-63. Available from: http://dx.doi.org/10.1016/j.jmsy.2013.05.005

Macknick J, Meldrum J, Nettles-Anderson S, Heath G, Miara A. Life cycle water use for photovoltaic electricity generation: A review and harmonization of literature estimates. 2014 IEEE 40th Photovolt Spec Conf PVSC 2014. 2014;15031:145860.

Macombe C, Leskinen P, Feschet P, Antikainen R. Social life cycle assessment of biodiesel production at three levels: A literature review and development needs. J Clean Prod [Internet]. 2013;52:205-16. Available from: http://dx.doi.org/10.1016/j.jclepro.2013.03.026

Manik Y, Leahy J, Halog a. Social life cycle assessment of palm oil biodiesel: a case study in Jambi Province of Indonesia. Int J Life Cycle Assess. 2013;18(7):138692.

Mc Bain D. Social indicators for use with Multiregional Input Output anlysis. Sydney; 2015.

McBain D, Alsamawi A. Quantitative accounting for social economic indicators. Nat Resour Forum [Internet]. 2014;38(3):193-202. Available from: 
http://doi.wiley.com/10.1111/1477-8947.12044

McDonald S, Thierfelder K. Deriving a Global Social Accounting Matrix from GTAP Versions 5 and 6 Data. UK; 2004. (GATP technical paper).

Meier PJ, Wilson PPH, Kulcinski GL, Denholm PL. US electric industry response to carbon constraint: A life-cycle assessment of supply side alternatives. Energy Policy. 2005;33(9):1099-108.

Mihelcic JR, Shonnard DR, Hokanson DR, Zhang Q, James VU, Sutherland JW, et al. Sustainability Science and Engineering: The Emergence of a New Metadiscipline. Environ Sci Technol. 2003;37(23):5314-24.

Miller RE, Blair PD. Input - Output Analysis. Foundations and extensions. Second. Cambridge: Cambridge University Press; 2009.

Miller RE, Blair PD. IO analysis: foundations and extensions. Vol. 1. 2015.

Moses L. The Stability of Interregional Trading Patterns and Input-Output Analysis. 1955 [cited 2015 Jul 30]; Available from: http://www.jstor.org/stable/1821380?seq=1\#page_scan_tab_contents

Munda G. Cost-benefit analysis in integrated environmental assessment: some methodological issues. Ecological Economics. 1996.

Myers N, Mittermeier RA, Mittermeier CG, Fonseca GAB, Kent J. Biodiversity hotspots for conservation priorities. 2000;403(February):853-8.

Navarro F. Modelos multisectoriales input-output en el estudio de los impactos ambientales : Una aplicación a la economía de Cataluña. 2012;217.

NEEDS. New Energy Externalities Developments for Sustainability Deliverable n ${ }^{\circ} 5$ RS 1d “External Costs Aggregation .” 2009;

Nelson D, Shrimali G, Goel S, Konda C, Kumar R. Meeting India' s Renewable 
Energy Targets : The Financing Challenge. San Francisco; 2012.

New Earth. SHDB supporting documentation. 2013a.

New Earth. SHDB supporting documentation. United States; $2013 b$.

NREL. Life Cycle Assessment of a Natural Gas Combined-Cycle Power Generation System [Internet]. NREL. 2000. Available from: http://library.umac.mo/ebooks/b28020261.pdf

NREL. Recommended Project Finance Structures for the Economic Analysis of FossilBased Energy Projects. USA; 2008.

NREL. SWERA database - National Renewable Energy Laboratory [Internet]. 2016 [cited 2016 Mar 28]. Available from: https://maps.nrel.gov/swera/\#/?aL=840V1j\%255Bv\%255D\%3Dt\&bL=ujuxuD\&cE $=0 \& \mathrm{IR}=0 \& \mathrm{mC}=31.475524020001806 \% 2 \mathrm{C}-108.6328125 \& \mathrm{zL}=6$

OECD. Household saving rates [Internet]. 2015 [cited 2016 Mar 28]. Available from: http://stats.oecd.org/Index.aspx?QueryId=51648

Office of Technology Evaluation. Statistical Analysis of U . S . Trade with Mexico for Calendar Year 2014. USA; 2015.

Ostermeyer Y, Wallbaum H, Reuter F. Multidimensional Pareto optimization as an approach for site-specific building refurbishment solutions applicable for life cycle sustainability assessment. Int J Life Cycle Assess. 2013;18(9):1762-79.

Ostro B. Outdoor air pollution: Assessing the environmental burden of disease at national and local levels. Geneva; 2004.

Ottinger RL, Wooley D, Robinson N, Hodas D, Babb S. Environmental costs of electricity [Internet]. New York, NY (United States); Oceana Publications; 1990 [cited 2015 Sep 10]. Available from: http://www.osti.gov/scitech/biblio/7041801 
Oxfam. Exploring the Links Between International Business and Poverty Reduction: Bouquets and beans from Kenya. Oxford [Internet]. 2013;128. Available from: http://www.oxfam.org/sites/www.oxfam.org/files/rr-exploring-links-ipl-povertyfootprint-090513-en.pdf

Papong S, Itsubo N, Malakul P, Shukuya M. Development of the social inventory database in Thailand using input-output analysis. Sustain. 2015;7(6):7684-713.

Pastakia CMR, Jensen A. The rapid impact assessment matrix (RIAM) for EIA. Environ Impact Assess Rev. 1998;18(5):461-82.

Pearce D, Bann C, Georgiou S. The social cost of fuel cycles. 1992 [cited 2015 Sep 10]; Available from: http://inis.iaea.org/Search/search.aspx?orig_q=RN:24067601

Ten Raa T. The Economics of Input-Output Analysis [Internet]. Cambridge: Cambridge University Press; 2006 [cited 2015 Jun 30]. Available from: /ebook.jsf?bid=CBO9780511610783

Ranis G, Stewart F. Success and failure in Human Development 1970-2007. Human Development Research Paper 2010/10. 2010.

Rodríguez-Serrano I, Caldés N, de la Rúa C, Lechón Y. Integrated sustainability impact assessment of alternative Solar Thermal and Natural Gas Combined Cycle for electricity production in Mexico. Energy Sustain Dev (forthcoming).

Rodríguez-Serrano I, Caldés N, De la Rúa C, Lechón Y. Assessing the three sustainability pillars through the Framework for Integrated Sustainability Assessment (FISA): case study of a Solar Thermal Electricity project in Mexico. J Clean Prod [Internet]. 2017;149(149):1127-43. Available from: http://www.sciencedirect.com/science/article/pii/S0959652617304055

Rodríguez-Serrano I, Caldés N, De la Rúa C, Lechón Y, Garrido A. Socioeconomic , 
environmental and social impacts of a concentrated solar power energy project in Northern Chile. Renew Energy Environ Sustain. 2016a;5:1-6.

Rodríguez-Serrano I, Caldés N, De la Rúa C, Lechón Y, Garrido A. Using the Framework for Integrated Sustainability Assessment (FISA) to expand the Multiregional Input-Output analysis to account for the three pillars of sustainability. Environ Dev Sustain. 2016b;.

Romero-Hernández S, Duarte Rodríguez-Granada B, Romero-Hernández O, Duncan W. Solar Energy Potential in Mexico’s Northern Border States. Mexico; 2012.

Santoyo-castelazo E, Azapagic A. Sustainability assessment of energy systems: integrating environmental, economic and social aspects. J Clean Prod [Internet]. 2014a;80:119-38. Available from: http://dx.doi.org/10.1016/j.jclepro.2014.05.061

Santoyo-castelazo E, Azapagic A. Sustainability assessment of energy systems: integrating environmental, economic and social aspects. $\mathrm{J}$ Clean Prod. 2014b;80:119-38.

Santoyo-Castelazo E, Gujba H, Azapagic A. Life cycle assessment of electricity generation in Mexico. Energy [Internet]. 2011;36(3):1488-99. Available from: http://dx.doi.org/10.1016/j.energy.2011.01.018

Sawaengsak W, Gheewala SH. Analysis of social and socio-economic impacts of sugarcane production: A case study in Nakhon Ratchasima province of Thailand. J Clean Prod [Internet]. 2017;142(Part 3):1169-1175. Available from: http://linkinghub.elsevier.com/retrieve/pii/S0959652616313129

Schoolman ED, Guest JS, Bush KF, Bell AR. How interdisciplinary is sustainability research? Analyzing the structure of an emerging scientific field. Sustain Sci. 2012;7(1):67-80. 
Secretaría de Economía. ProMéxico. Inversión y Comercio. Energías renovables. Mexico DF; 2013.

Secretaría de Economía. Industria de Energías Renovables Prospectiva y Oportunidades de Negocio en México. Mexico DF; 2015.

Secretaría General. Ley general de cambio climático, DOF 06-06-2012. Mexico; 2012 p. $1-44$.

SEMARNAT. Towards a Climate Market in Mexico. Mexico; 2016.

SENER. Prospectiva del Sector Eléctrico 2013-2027. Mexico; 2013.

SENER. Prospectiva del Sector Eléctrico 2014-2028. Mexico DF; 2014.

SENER. Programa de Desarrollo del Sistema Eléctrico Nacional 2015-2029. Mexico; 2015a.

SENER. Prospectiva del Gas Natural y Gas L.P. 2015-2029. Documento nacional. Mexico; 2015b.

SENER. Prospectiva del Sector Eléctrico 2015-2029. Mexico; 2015c.

Senhbruch K. From the quantity to the quality of employment: an application of the capability approach to the Chilean labour market. Berkeley; 2004. (CLAS Working Papers). Report No.: 9.

Shakya BD, Aye L, Musgrave P. Technical feasibility and financial analysis of hybrid wind-photovoltaic system with hydrogen storage for Cooma. Int J Hydrogen Energy. 2005;30(1):9-20.

SHDB. Social Hotspot Database [Internet]. 2016 [cited 2016 Mar 28]. Available from: http://socialhotspot.org/

Singh B, Strømman AH, Hertwich EG. Comparative life cycle environmental assessment of CCS technologies. Int $\mathrm{J}$ Greenh Gas Control [Internet]. 
2011;5(4):911-21. Available from: http://dx.doi.org/10.1016/j.ijggc.2011.03.012

Smith LM, Case JL, Smith HM, Harwell LC, Summers JK. Relating ecoystem services to domains of human well-being: Foundation for a U.S. index. Ecol Indic [Internet]. 2013;28:79-90. Available from: http://dx.doi.org/10.1016/j.ecolind.2012.02.032

SolarPaces, Greenpeace, ESTELA. Solar thermal electricity global outlook 2016. Execituve summary. 2016.

Spence and Bourlakis. The evolution from corporate social responsibility to supply chain responsibility: the case of Waitrose: Supply Chain Management: An International Journal: Vol 14, No 4. 2009 [cited 2015 Jul 30]; Available from: http://www.emeraldinsight.com/doi/full/10.1108/13598540910970126

Stanford University. Guidelines for LCCA in Buildings. October. Standford; 2005.

Starke AR, Cardemil JM, Escobar R, Lemos LL, Colle S. Assessing the performance of Concentrated Solar Power plants in selected locations of Chile. 2015;

Stone R. The social accounts from a consumer's point of view. An Outline and Discussion of the Revised United Nations System of National Accounts. Rev Income Wealth [Internet]. 1966 Mar [cited 2015 Aug 27];12(1):1-33. Available from: http://doi.wiley.com/10.1111/j.1475-4991.1966.tb00709.x

Stone R. Social Accounting: The State of Play [Internet]. 1986 [cited 2015 Aug 17]. Available from: http://www.jstor.org/stable/3440380?seq=1\#page_scan_tab_contents

Suh S, Huppes G. Missing Inventory Estimation Tool Using Extended Input-Output Analysis. 2002;7(3):134-40.

Suh S, Nakamura S. Editorials Five Years in the Area of Input-Output and Hybrid LCA. 
Int J Life Cycle Assess. 2007;12(6):351-2.

Suh et al. Critical Review System Boundary Selection in Life-Cycle Inventories Using Hybrid Approaches. 2006;38(3):657-64.

Swarr TE, Hunkeler D, Klöpffer W, Pesonen H, Ciroth A, Brent AC, et al. Environmental life-cycle costing: a code of practice. Int J Life Cycle Assess. 2011;16(16):389-91.

Tate E. Uncertainty Analysis for a Social Vulnerability Index. Ann Assoc Am Geogr [Internet]. 2012 Aug 20 [cited 2015 Sep 7];103(3):526-43. Available from: http://www.researchgate.net/publication/254227626_Uncertainty_Analysis_for_a_ Social_Vulnerability_Index

Telsnig T, Ferrán-Díaz G. Solar Mining Technology Options - Techno-economicecological datasheet. Concentrated Solar Power tower with storage. Stuttgart; 2016.

Teske S, Sawyer S, Ash K. Energy [ r ] evolution. United States; 2014.

Thornley P, Rogers J, Huang Y. Quantification of employment from biomass power plants. Renew Energy. 2008;33:1922-7.

Timmer MP, Dietzenbacher E, Los B, Stehrer R, de Vries GJ. An Illustrated User Guide to the World Input-Output Database: the Case of Global Automotive Production. Rev Int Econ [Internet]. 2015 Aug [cited 2016 Mar 17];23(3):575-605. Available from: http://doi.wiley.com/10.1111/roie.12178

Traverso M, Finkbeiner M, Jørgensen A, Schneider L. Life Cycle Sustainability Dashboard. J Ind Ecol [Internet]. 2012 Oct [cited 2016 Oct 24];16(5):680-8. Available from: http://doi.wiley.com/10.1111/j.1530-9290.2012.00497.x

Tukker A, Dietzenbacher E. Global Multiregional Input-Output Frameworks: an 
Introduction and Outlook. Econ Syst Res [Internet]. 2013;25(1):1-19. Available from: http://dx.doi.org/10.1080/09535314.2012.761179

Turchi CS, Heath G a. Molten Salt Power Tower Cost Model for the System Advisor Model ( SAM ). 2013;(February):1-53. Available from: www.nrel.gov

U.S. Energy Information Agency. Mexico energy report [Internet]. Vol. 2014. United States; 2014. Available from: http://www.eia.gov/countries/analysisbriefs/Mexico/mexico.pdf

Understanding Children's Work. La experiencia mexicana en la reducción del trabajo infantil: evidencia empírica y lecciones políticas. Roma; 2012.

UNEP, SETAC. Towards a Life Cycle Sustainability Assessment. 2011.

UNEP, SETAC, Life Cycle Iniciative. Guidelines for Social Life Cycle Assessment of Products [Internet]. Vol. 15, Management. Belgium; 2009. Available from: http://www.unep.fr/shared/publications/pdf/DTIx1164xPA-guidelines_sLCA.pdf

United Nations. Synthesis report on the aggregate effect of the intended nationally determined contributions. Vol. 18808. 2015.

United Nations. The Sustainable Development Goals Report 2016 [Internet]. New York; 2016a. Available from: http://www.theguardian.com/globaldevelopment/ng-interactive/2015/jan/19/sustainable-development-goals-changingworld-17-steps-interactive

United Nations. United Nations Statistics Division - Classifications Registry [Internet]. 2016b [cited 2016 Mar 28]. Available from: http://unstats.un.org/unsd/cr/registry/regcs.asp?Cl=17\&Lg=1\&Co=23

Uriel E, Ferri J, Moltó ML. La MCS-90 y la SAM-90 . Evaluación de las diferencias ( * ). Estadística Española. 2003;45(152):87-114. 
Vucetich J a., Nelson MP. Sustainability: Virtuous or Vulgar? Bioscience. 2010;60(7):539-44.

Weaver PM, Rotmans J. Integrated sustainability assessment : what is it, why do it and how ? Jan Rotmans. Int J Innov Sustain Dev. 2006;1(4):284-303.

Weidema BP. The integration of economic and social aspects in life cycle impact assessment. Int J Life Cycle Assess [Internet]. 2006;11(S1):89-96. Available from: http://www.springerlink.com/index/10.1065/lca2006.04.016

Weisser D. A guide to life-cycle greenhouse gas ( GHG ) emissions from electric supply technologies. 2001;1-27.

Wiedmann T, Lenzen M, Turner K, Barrett J. Examining the global environmental impact of regional consumption activities - Part 2: Review of input-output models for the assessment of environmental impacts embodied in trade. Ecol Econ. 2007;61(1):15-26.

Wiedmann T, Wood R, Minx JC, Lenzen M, Guan D, Harris R. A carbon footprint time series of the UK - results from a multi-region input-output model. Econ Syst Res [Internet]. 2010 Mar 13 [cited 2015 Jul 30];22(1):19-42. Available from: http://www.tandfonline.com/doi/abs/10.1080/09535311003612591?src=recsys\#.V boJGbPtmko

WIOD. World Input Output Database [Internet]. 2016 [cited 2016 Mar 28]. Available from: http://www.wiod.org/new_site/home.htm

Wolff H, Chong H, Auffhammer M. Classification, detection and consuquences of data error: evidence from the Human Development Index. 2010;

World Bank. Mexico: Estimation of the Economic Opportunity Cost of Capital for Public Investment Projects. Mexico; 2014. 
World Commission on Environment and Development. Our Common Future (The Brundtland Report). Vol. 4, Medicine, Conflict and Survival. 1987.

Wyckoff AW, Roop JM. The embodiment of carbon in imports of manufactured products. Energy Policy. 1994;22(3):187-94.

Zafrilla JE, Cadarso M-N, Monsalve F, De La Ruá C. How Carbon-Friendly Is Nuclear Energy? A Hybrid MRIO-LCA Model of a Spanish Facility. Environ Sci Technol. 2014;

Zamagni A, Amerighi O, Buttol P. Strengths or bias in social LCA ? Int J Life Cycle Assess. 2011;16(august 2011):596-8. 


\section{Appendices}

\section{Appendix 3.1. Detailed investment costs shares breakdown of the STE case}

\section{study}

Information about detailed investment costs shares breakdown of the STE case study plant by national (Mexico) or imported manufacturing and economic sector assigned

\begin{tabular}{|c|c|c|c|c|c|}
\hline $\begin{array}{l}\text { STE detailed cost } \\
\text { shares breakdown }\end{array}$ & $\begin{array}{l}\text { Export } \\
\text { countr } \\
\text { y }\end{array}$ & $\begin{array}{l}\text { Detailed } \\
\text { shares } \\
\text { costs } \\
\text { breakdow } \\
\text { n } \\
\end{array}$ & $\begin{array}{l}\text { Share } \\
\text { cost } \\
\text { nationa } \\
\text { l }\end{array}$ & $\begin{array}{l}\text { Share of } \\
\text { costs } \\
\text { internationa } \\
\text { l }\end{array}$ & $\begin{array}{l}\text { Economic } \\
\text { sector } \\
\text { assigned }\end{array}$ \\
\hline $\begin{array}{l}\text { SITE } \\
\text { IMPROVEMENTS }\end{array}$ & & & & & \\
\hline Site Preparation & - & $2 \%$ & $2 \%$ & $0 \%$ & \\
\hline Clearing \& Grubbing & - & $0 \%$ & $0 \%$ & $0 \%$ & Construction \\
\hline $\begin{array}{l}\text { Grading, Drainage, } \\
\text { Remediation, Retention, } \\
\text { \& Detention }\end{array}$ & - & $2 \%$ & $2 \%$ & $0 \%$ & \\
\hline Evaporation Pond & - & $6 \%$ & $6 \%$ & $0 \%$ & \\
\hline $\begin{array}{l}\text { Roads, Parking, } \\
\text { Fencing }\end{array}$ & - & $84 \%$ & $84 \%$ & $0 \%$ & \\
\hline $\begin{array}{l}\text { Water Supply } \\
\text { Infrastructure }\end{array}$ & - & $6 \%$ & $6 \%$ & $0 \%$ & \\
\hline Total site improvements & & $100 \%$ & $100 \%$ & $0 \%$ & \\
\hline \multicolumn{6}{|l|}{ SOLAR FIELD } \\
\hline Mirrors & - & $22 \%$ & $22 \%$ & $0 \%$ & $\begin{array}{l}\text { Non metallic } \\
\text { minerals }\end{array}$ \\
\hline Drives & USA & $39 \%$ & $10 \%$ & $29 \%$ & $\begin{array}{l}\text { Electical } \\
\text { Equipment }\end{array}$ \\
\hline $\begin{array}{l}\text { Pedestal, Mirror } \\
\text { Support, Foundation }\end{array}$ & - & $36 \%$ & $36 \%$ & $0 \%$ & $\begin{array}{l}\text { Basic\&Fabri } \\
\text { cated Metals }\end{array}$ \\
\hline $\begin{array}{l}\text { Controls and Wired } \\
\text { Connections }\end{array}$ & USA & $4 \%$ & $1 \%$ & $3 \%$ & $\begin{array}{l}\text { Electical } \\
\text { Equipment }\end{array}$ \\
\hline Total solar field & & $100 \%$ & $68 \%$ & $32 \%$ & \\
\hline \multicolumn{6}{|l|}{ TOWER } \\
\hline Tower & - & $78 \%$ & $78 \%$ & $0 \%$ & $\begin{array}{l}30 \% \\
\text { Basic\&Fabri } \\
\text { cated Metals; } \\
70 \% \text { Non } \\
\text { metallic } \\
\text { minerals }\end{array}$ \\
\hline
\end{tabular}




\begin{tabular}{|c|c|c|c|c|c|}
\hline \multirow{3}{*}{$\begin{array}{l}\text { Riser and Downcomer } \\
\text { piping \& insulation } \\
\text { Total tower }\end{array}$} & - & $11 \%$ & $11 \%$ & $0 \%$ & \multirow{3}{*}{$\begin{array}{l}\text { Construction } \\
\text { Basic\&Fabri } \\
\text { cated Metals }\end{array}$} \\
\hline & USA & $11 \%$ & $0 \%$ & $11 \%$ & \\
\hline & & $100 \%$ & $89 \%$ & $11 \%$ & \\
\hline \multicolumn{6}{|l|}{ RECEIVER SYSTEM } \\
\hline Receiver & USA & $65 \%$ & $13 \%$ & $52 \%$ & $\begin{array}{l}\text { Basic\&Fabri } \\
\text { cated Metals }\end{array}$ \\
\hline $\begin{array}{l}\text { Horizontal piping \& } \\
\text { insulation }\end{array}$ & USA & $13 \%$ & $6 \%$ & $6 \%$ & $\begin{array}{l}\text { Basic\&Fabri } \\
\text { cated Metals- } \\
\text { USA; } \\
\text { Construction } \\
\text {-MEX }\end{array}$ \\
\hline Cold Salt Pump(s) & NLD & $9 \%$ & $0 \%$ & $9 \%$ & Machiney \\
\hline $\begin{array}{l}\text { Controls, Instruments, } \\
\text { Heat Trace }\end{array}$ & USA & $12 \%$ & $2 \%$ & $10 \%$ & $\begin{array}{l}\text { Electical } \\
\text { Equipment }\end{array}$ \\
\hline Spare Parts & USA & $2 \%$ & $0 \%$ & $1 \%$ & $\begin{array}{l}\text { Basic\&Fabri } \\
\text { cated Metals }\end{array}$ \\
\hline Total receiver & & $100 \%$ & $22 \%$ & $78 \%$ & \\
\hline \multicolumn{6}{|l|}{$\begin{array}{l}\text { THERMAL ENERGY } \\
\text { STORAGE (TES) }\end{array}$} \\
\hline Cold Tank(s) & USA & $9 \%$ & $6 \%$ & $3 \%$ & $\begin{array}{l}\text { Basic\&Fabri } \\
\text { cated Metals }\end{array}$ \\
\hline Hot Tank(s) & USA & $20 \%$ & $14 \%$ & $6 \%$ & $\begin{array}{l}\text { Basic\&Fabri } \\
\text { cated Metals }\end{array}$ \\
\hline Media & DEU & $64 \%$ & $0 \%$ & $64 \%$ & Chemical \\
\hline $\begin{array}{l}\text { Piping, Insulation, } \\
\text { Valves, \& Fittings }\end{array}$ & USA & $3 \%$ & $1.5 \%$ & $1.5 \%$ & $\begin{array}{l}\text { Basic\&Fabri } \\
\text { cated Metals- } \\
\text { USA; } \\
\text { Construction } \\
\text {-MEX }\end{array}$ \\
\hline $\begin{array}{l}\text { Foundations \& Support } \\
\text { Structures }\end{array}$ & - & $4 \%$ & $4 \%$ & $0 \%$ & $\begin{array}{l}\text { Basic\&Fabri } \\
\text { cated Metals }\end{array}$ \\
\hline $\begin{array}{l}\text { Instrumentation \& } \\
\text { Controls }\end{array}$ & USA & $1 \%$ & $0 \%$ & $0 \%$ & $\begin{array}{l}\text { Electical } \\
\text { Equipment }\end{array}$ \\
\hline Total TES & & $100 \%$ & $26 \%$ & $74 \%$ & \\
\hline $\begin{array}{l}\text { BALANCE OF PLANT } \\
\text { (BOP) \& STEAM } \\
\text { GENERATION } \\
\text { SYSTEM }\end{array}$ & & & & & \\
\hline $\begin{array}{l}\text { Steam Generation Heat } \\
\text { Exchangers and } \\
\text { Equipment }\end{array}$ & USA & $29 \%$ & $0 \%$ & $29 \%$ & Machinery \\
\hline Hot Salt Pump(s) & NLD & $12 \%$ & $0 \%$ & $12 \%$ & Machinery \\
\hline
\end{tabular}




\begin{tabular}{|c|c|c|c|c|c|}
\hline $\begin{array}{l}\text { Steam Piping, } \\
\text { Insulation, Valves, \& } \\
\text { Fittings }\end{array}$ & USA & $5 \%$ & $2 \%$ & $2 \%$ & $\begin{array}{l}\text { Basic\&Fabri } \\
\text { cated Metals- } \\
\text { USA; } \\
\text { Construction } \\
\text {-MEX }\end{array}$ \\
\hline $\begin{array}{l}\text { Electrical, } \\
\text { Instrumentation, and } \\
\text { Controls System }\end{array}$ & USA & $16 \%$ & $3 \%$ & $12 \%$ & $\begin{array}{l}\text { Electical } \\
\text { Equipment }\end{array}$ \\
\hline $\begin{array}{l}\text { Foundations \& Support } \\
\text { Structures }\end{array}$ & - & $38 \%$ & $38 \%$ & $0 \%$ & $\begin{array}{l}\text { Basic\&Fabri } \\
\text { cated Metals }\end{array}$ \\
\hline $\begin{array}{l}\text { Total BOP and steam } \\
\text { generation systeM }\end{array}$ & & $100 \%$ & $44 \%$ & $56 \%$ & \\
\hline $\begin{array}{l}\text { POWER PLANT - } \\
\text { POWER BLOCK }\end{array}$ & & & & & \\
\hline $\begin{array}{l}\text { Steam Turbine } \\
\text { Generator Island }\end{array}$ & DEU & $24 \%$ & $0 \%$ & $24 \%$ & Machinery \\
\hline Blowdown System & USA & $0,2 \%$ & $0 \%$ & $0 \%$ & Machinery \\
\hline Cooling Systems & USA & $18 \%$ & $9 \%$ & $9 \%$ & Machinery \\
\hline Condensate System & USA & $1 \%$ & $0 \%$ & $0 \%$ & Machinery \\
\hline Feedwater System & USA & $6 \%$ & $3 \%$ & $3 \%$ & Machinery \\
\hline $\begin{array}{l}\text { Auxiliary Cooling } \\
\text { Water System }\end{array}$ & USA & $2 \%$ & $1 \%$ & $1 \%$ & Machinery \\
\hline $\begin{array}{l}\text { Steam Piping, } \\
\text { Insulation, Valves, \& } \\
\text { Fittings }\end{array}$ & USA & $5 \%$ & $2 \%$ & $2 \%$ & $\begin{array}{l}\text { Basic\&Fabri } \\
\text { cated Metals- } \\
\text { USA; } \\
\text { Construction } \\
\text {-MEX }\end{array}$ \\
\hline $\begin{array}{l}\text { Water Treatment } \\
\text { System }\end{array}$ & USA & $3 \%$ & $1 \%$ & $1 \%$ & Machinery \\
\hline $\begin{array}{l}\text { Power Distribution } \\
\text { Systems }\end{array}$ & DEU & $15 \%$ & $0 \%$ & $15 \%$ & $\begin{array}{l}\text { Electical } \\
\text { Equipment }\end{array}$ \\
\hline Back-up Power Systems & USA & $3 \%$ & $1 \%$ & $1 \%$ & $\begin{array}{l}\text { Electical } \\
\text { Equipment }\end{array}$ \\
\hline $\begin{array}{l}\text { Instruments and } \\
\text { Controls System }\end{array}$ & USA & $3 \%$ & $1 \%$ & $2 \%$ & $\begin{array}{l}\text { Electical } \\
\text { Equipment }\end{array}$ \\
\hline Fire Protection System & USA & $3 \%$ & $1 \%$ & $2 \%$ & $\begin{array}{l}\text { Electical } \\
\text { Equipment }\end{array}$ \\
\hline $\begin{array}{l}\text { Foundations \& Support } \\
\text { Structures }\end{array}$ & MEX & $3 \%$ & $3 \%$ & $0 \%$ & $\begin{array}{l}\text { Basic\&Fabri } \\
\text { cated Metals }\end{array}$ \\
\hline Buildings & MEX & $8 \%$ & $8 \%$ & $0 \%$ & Construction \\
\hline $\begin{array}{l}\text { BOP Mechanical } \\
\text { Systems }\end{array}$ & USA & $3 \%$ & $2 \%$ & $2 \%$ & Machinery \\
\hline BOP Electrical Systems & USA & $3 \%$ & $2 \%$ & $2 \%$ & $\begin{array}{l}\text { Electical } \\
\text { Equipment }\end{array}$ \\
\hline
\end{tabular}




\begin{tabular}{|c|c|c|c|c|c|}
\hline Total power block & & $100 \%$ & $34 \%$ & $66 \%$ & \\
\hline CONTINGENCY & - & $100 \%$ & $100 \%$ & $0 \%$ & Financial \\
\hline $\begin{array}{l}\text { EPC and OWNER } \\
\text { COSTS }\end{array}$ & & & & & \multirow{7}{*}{$\begin{array}{l}\text { Renting of } \\
\text { Machinery } \\
\text { and Other } \\
\text { Business } \\
\text { Activities }\end{array}$} \\
\hline $\begin{array}{l}\text { Engineering (EPCM } \\
\text { basis) }\end{array}$ & - & $20 \%$ & $20 \%$ & $0 \%$ & \\
\hline $\begin{array}{l}\text { Construction } \\
\text { management (EPCM } \\
\text { basis) }\end{array}$ & - & $15 \%$ & $15 \%$ & $0 \%$ & \\
\hline $\begin{array}{l}\text { Commissioning / start- } \\
\text { up (EPCM basis) }\end{array}$ & - & $2 \%$ & $2 \%$ & $0 \%$ & \\
\hline $\begin{array}{l}\text { Owner's Engg \& } \\
\text { Project Management }\end{array}$ & - & $36 \%$ & $36 \%$ & $0 \%$ & \\
\hline $\begin{array}{l}\text { Permitting, Licensing, } \\
\text { Legal }\end{array}$ & - & $27 \%$ & $27 \%$ & $0 \%$ & \\
\hline Total EPC costs & & $100 \%$ & $100 \%$ & $0 \%$ & \\
\hline LAND COSTS & - & $100 \%$ & $100 \%$ & $0 \%$ & $\begin{array}{l}\text { Real State } \\
\text { Activities }\end{array}$ \\
\hline SALES TAX & - & $100 \%$ & $100 \%$ & $0 \%$ & Financial \\
\hline
\end{tabular}

Source: Own elaboration with cost data and imports information provided by ESTELA and cost breakdown based on Turchi and Heath (2013) 


\section{Appendix 3.2. Excluded social risk indicators in the analysis}

Social risk indicators within the five social impact categories excluded in the assesment and reasons indicated by numbers in brackets

\begin{tabular}{|c|c|c|c|c|}
\hline Labor rights & $\begin{array}{l}\text { Health and } \\
\text { safety }\end{array}$ & $\begin{array}{l}\text { Human } \\
\text { rights }\end{array}$ & $\begin{array}{l}\text { Governan } \\
\text { ce }\end{array}$ & $\begin{array}{l}\text { Community } \\
\text { infrastruct } \\
\text { ure }\end{array}$ \\
\hline $\begin{array}{l}\text { Wage Assessment:Sector Average } \\
\text { Wage - Not Characterized (1) }\end{array}$ & $\begin{array}{l}\text { Risk of non-fatal } \\
\text { injuries by } \\
\text { country (5) }\end{array}$ & $\begin{array}{l}\text { Presence } \\
\text { of } \\
\text { Indigenous } \\
\text {-Not } \\
\text { Characteri } \\
\text { zed (1) }\end{array}$ & $\begin{array}{l}\text { Characteri } \\
\text { zation of } \\
\text { Bertelsman } \\
\mathrm{n} \\
\text { Transform } \\
\text { ation Index } \\
\text { - Rule of } \\
\text { Law (8) }\end{array}$ & $\begin{array}{l}\text { Risk of no } \\
\text { access to an } \\
\text { Improved } \\
\text { Source of } \\
\text { Drinking } \\
\text { Water-total } \\
\text { (9) }\end{array}$ \\
\hline $\begin{array}{l}\text { Characterization of International } \\
\text { Labour Organization's Forced } \\
\text { Labor Regional Estimates (2) }\end{array}$ & $\begin{array}{l}\text { Risk of fatal } \\
\text { injuries by } \\
\text { country ( } 5)\end{array}$ & $\begin{array}{l}\text { Characteri } \\
\text { zation of } \\
\text { Indigenous } \\
\text { Population } \\
\text { (10) }\end{array}$ & $\begin{array}{l}\text { Characteri } \\
\text { zation of } \\
\text { Global } \\
\text { Integrity } \\
\text { Index (8) }\end{array}$ & $\begin{array}{l}\text { Risk of no } \\
\text { access to an } \\
\text { Improved } \\
\text { source of } \\
\text { Sanitation- } \\
\text { total (9) }\end{array}$ \\
\hline $\begin{array}{l}\text { Characterization of U.S. } \\
\text { Department of Labor's Trafficking } \\
\text { in Person's Forced Labor Tiers (2) }\end{array}$ & $\begin{array}{l}\text { Risk of workplace } \\
\text { noise exposure to } \\
\text { males-indicator } 2 \\
\text { (4) }\end{array}$ & $\begin{array}{l}\text { Risk of a } \\
\text { country not } \\
\text { adopting } \\
\text { Intl } \\
\text { Conventio } \\
\text { ns to } \\
\text { Protect } \\
\text { Indigenous } \\
\text {-indicator2 } \\
\text { (4) }\end{array}$ & $\begin{array}{l}\text { Characteri } \\
\text { zation of } \\
\text { World } \\
\text { Justice } \\
\text { Project - } \\
\text { Rule of } \\
\text { Law Index } \\
\text { (8) }\end{array}$ & $\begin{array}{l}\text { Risk that } \\
\text { children do } \\
\text { not attend } \\
\text { school, total } \\
\text { (3) }\end{array}$ \\
\hline $\begin{array}{l}\text { Child Labor:Risk of Child Labor in } \\
\text { sector, Total (qualitative) (3) }\end{array}$ & $\begin{array}{l}\text { Risk of workplace } \\
\text { noise exposure to } \\
\text { females- } \\
\text { indicator2 (4) }\end{array}$ & $\begin{array}{l}\text { Characteri } \\
\text { zation of } \\
\text { Heidelberg } \\
\text { Barometer- } \\
\text { indicator2 } \\
\text { (4) }\end{array}$ & $\begin{array}{l}\text { World } \\
\text { Bank } \\
\text { Worldwide } \\
\text { Governanc } \\
\text { e } \\
\text { Indicator's } \\
\text { Corruption } \\
\text { Index-Not } \\
\text { Characteri } \\
\text { zed (1) }\end{array}$ & $\begin{array}{l}\text { Characteriza } \\
\text { tion of } \\
\text { family labor } \\
\text { in } \\
\text { Agriculture, } \\
\text { Forestry, } \\
\text { Fishing (7) }\end{array}$ \\
\hline $\begin{array}{l}\text { Risk of Child Labor in sector, Total } \\
\text { (quantitative) (3) }\end{array}$ & $\begin{array}{l}\text { Overall Risk of } \\
\text { workplace noise } \\
\text { exposure, both } \\
\text { genders (3) }\end{array}$ & $\begin{array}{l}\text { Characteri } \\
\text { zation of } \\
\text { Heidelberg } \\
\text { Barometer- } \\
\text { indicator3 } \\
\text { (4) }\end{array}$ & $\begin{array}{l}\text { Overall } \\
\text { Risk of } \\
\text { Corruption } \\
\text { (9) }\end{array}$ & $\begin{array}{l}\text { Characteriza } \\
\text { tion of } \\
\text { commercial } \\
\text { labor in } \\
\text { Agriculture, } \\
\text { Forestry, } \\
\text { Fishing (7) }\end{array}$ \\
\hline $\begin{array}{l}\text { Characterization of the number of } \\
\text { emigrants (10) }\end{array}$ & $\begin{array}{l}\text { Risk of loss of life } \\
\text { years by miners' } \\
\text { pneumoconiosis }\end{array}$ & $\begin{array}{l}\text { Characteri } \\
\text { zation of } \\
\text { Cingranelli }\end{array}$ & & $\begin{array}{l}\text { Characteriza } \\
\text { tion of small } \\
\text { agricultural }\end{array}$ \\
\hline
\end{tabular}




\begin{tabular}{|c|c|c|c|}
\hline & $\begin{array}{l}\text { due to working in } \\
\text { coal mines (coal } \\
\text { sector only) ( } 7 \text { ) }\end{array}$ & $\begin{array}{l}\text {-Richards } \\
\text { Human } \\
\text { Rights } \\
\text { Dataset- } \\
\text { indicator2 } \\
\text { (4) }\end{array}$ & $\begin{array}{l}\text { land } \\
\text { holdings (7) }\end{array}$ \\
\hline $\begin{array}{l}\text { Characterization of the number of } \\
\text { immigrants (10) }\end{array}$ & $\begin{array}{l}\text { Risk of } \\
\text { contracting Hep B } \\
\text { or C or HIV from } \\
\text { a sharps injury } \\
\text { working in the } \\
\text { health care sector- } \\
\text { indicator2 (public } \\
\text { admin, defense, } \\
\text { education, health } \\
\text { sector only) (7) }\end{array}$ & $\begin{array}{l}\text { Characteri } \\
\text { zation of } \\
\text { Cingranelli } \\
\text {-Richards } \\
\text { Human } \\
\text { Rights } \\
\text { Dataset- } \\
\text { indicator3 } \\
\text { (4) }\end{array}$ & $\begin{array}{l}\text { Characteriza } \\
\text { tion of large } \\
\text { agricultural } \\
\text { land } \\
\text { holdings (7) }\end{array}$ \\
\hline $\begin{array}{l}\text { Characterization of population that } \\
\text { are immigrants (10) }\end{array}$ & $\begin{array}{l}\text { Risk of } \\
\text { contracting Hep B } \\
\text { or C or HIV from } \\
\text { a sharps injury } \\
\text { working in the } \\
\text { health care sector- } \\
\text { indicator3 (public } \\
\text { admin, defense, } \\
\text { education, health } \\
\text { sector only) (7) }\end{array}$ & & \\
\hline \multicolumn{4}{|l|}{$\begin{array}{l}\text { Risk that a country has not ratified } \\
\text { international conventions or set up } \\
\text { policies for immigrants- } \\
\text { indicator } 2 / 3 / 4(4)\end{array}$} \\
\hline \multicolumn{4}{|l|}{$\begin{array}{l}\text { Risk that Country does not provide } \\
\text { adequate labor laws (5) }\end{array}$} \\
\hline \multicolumn{4}{|l|}{$\begin{array}{l}\text { Risk that Country has not ratified } \\
\text { ILO conventions ( } 5 \text { ) }\end{array}$} \\
\hline $\begin{array}{l}\text { Risk of Unemployment by Sector } \\
\text { (6) }\end{array}$ & & & \\
\hline
\end{tabular}
(1) Indicator not characterized
(2) Only country risk figure
(3) Indicator included by separate male/female figures
(4) Used of several indicators for the assessment of the same risk
(5) Same indicator included by sector
(6) Indicator with NAN (Not A Number) value
(7) Risk related to a unique specific sector
(8) Most of the countries have no data for this indicator
(9) Indicator included within other separate indicators
(10) Characterization (not a risk)

Source: Own elaboration based on SHDB risks and indicators. 


\section{Appendix 4.1. Social themes and impact categories within the SHDB}
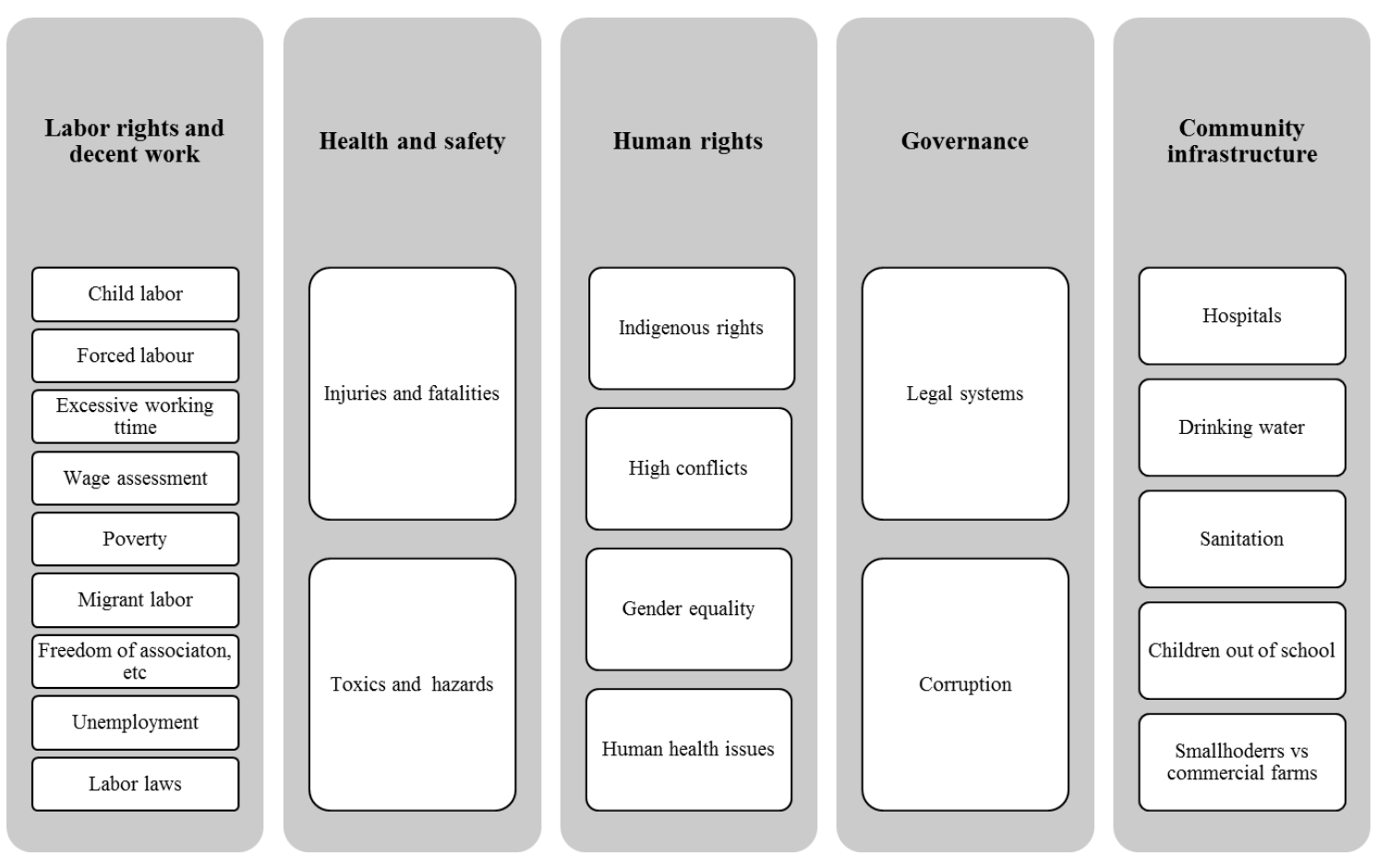

Source: Own elaboration based on SHDB 


\section{Appendix 4.2. FISA framework and methodological steps}

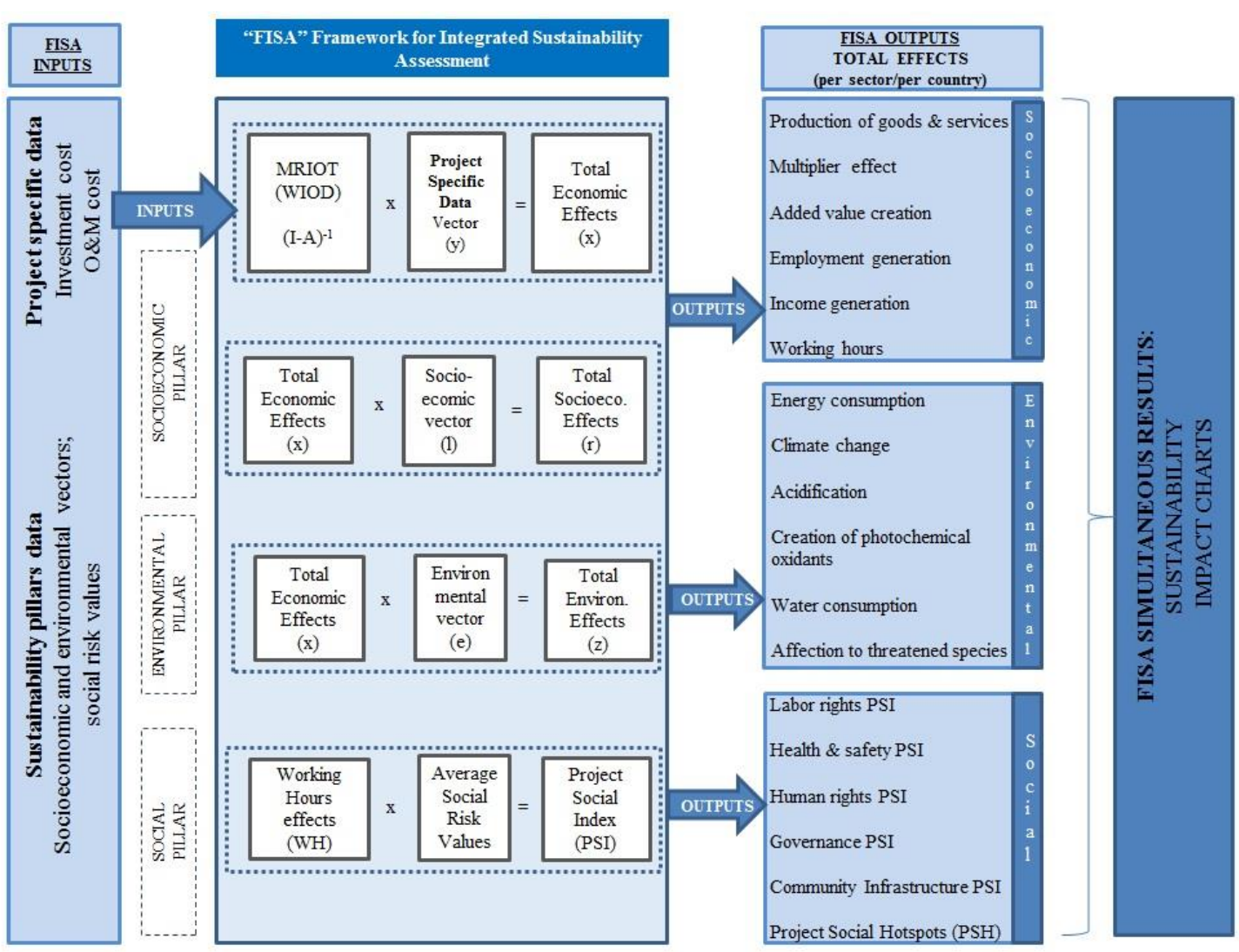

Source: Own elaboration 


\section{Appendix 4.3. Investment cost for STE and NGCC and labor contribution}

\begin{tabular}{|c|c|c|c|c|c|}
\hline $\begin{array}{l}\text { STE Investment } \\
\text { cost breakdown }\end{array}$ & $\begin{array}{l}\text { STE } \\
\text { Investment } \\
\text { costs } \\
\text { (US\$/MWh) }\end{array}$ & $\begin{array}{l}\text { Labor } \\
\text { contribution } \\
\text { (in } \\
\text { percentage) }\end{array}$ & $\begin{array}{l}\text { NGCC Investment } \\
\text { cost breakdown }\end{array}$ & $\begin{array}{l}\text { NGCC } \\
\text { Investment } \\
\text { costs } \\
\text { (US\$/MWh) } \\
\end{array}$ & $\begin{array}{l}\text { Labor } \\
\text { contribution } \\
\text { (in } \\
\text { percentage) }\end{array}$ \\
\hline $\begin{array}{l}\text { Site } \\
\text { improvements }\end{array}$ & 1.30 & $45 \%$ & $\begin{array}{l}\text { Improvements to } \\
\text { site }\end{array}$ & 0.02 & $68 \%$ \\
\hline Heliostat field & 11.95 & $11 \%$ & $\begin{array}{l}\text { Eearth work and } \\
\text { piling }\end{array}$ & 0.23 & $12 \%$ \\
\hline Tower costs & 1.69 & $46 \%$ & $\begin{array}{l}\text { Circulating Water } \\
\text { system }\end{array}$ & 0.52 & $33 \%$ \\
\hline Receiver & 5.05 & $18 \%$ & $\begin{array}{l}\text { Heat Recovery } \\
\text { Boilers, Gas } \\
\text { Turbine }\end{array}$ & 2.57 & $14 \%$ \\
\hline $\begin{array}{l}\text { Thermal Energy } \\
\text { Storage }\end{array}$ & 2.42 & $9 \%$ & $\begin{array}{l}\text { Steam Turbines and } \\
\text { Generator }\end{array}$ & 0.88 & $29 \%$ \\
\hline Balance of plant & 3.10 & $39 \%$ & $\begin{array}{l}\text { Other Mechanical } \\
\text { Equipment, } \\
\text { buildings and } \\
\text { construction costs }\end{array}$ & 3.22 & $40 \%$ \\
\hline Power block & 9.69 & $37 \%$ & $\begin{array}{l}\text { Piping } \\
\text { Electrical equipment }\end{array}$ & $\begin{array}{l}0.57 \\
0.69\end{array}$ & $\begin{array}{l}39 \% \\
46 \%\end{array}$ \\
\hline Tax & 1.51 & - & $\begin{array}{l}\text { Substation and } \\
\text { electrical } \\
\text { distribution }\end{array}$ & 0.35 & $19 \%$ \\
\hline $\begin{array}{l}\text { Engineering, } \\
\text { procurement } \\
\text { and construction } \\
\text { contracts (EPC) } \\
\text { and owner costs }\end{array}$ & 4.14 & - & $\begin{array}{l}\text { Architect/Engineer } \\
\text { Services and other } \\
\text { non mannual staff } \\
\text { salaries }\end{array}$ & 2.35 & $9 \%$ \\
\hline Land costs & 1.52 & - & Land cost & 1.05 & - \\
\hline Contingency & 2.46 & & Contingency & 1.55 & - \\
\hline Total & 44.84 & $19 \%$ & Total & 14.00 & $21 \%$ \\
\hline
\end{tabular}

Source: Own elaboration based on ESTELA and CFE (2012) cost data, and cost breakdown from Turchi and Heath (2013) and Battelle (198) 


\section{Appendix 4.4. Annual costs for STE and NGCC (without fuel and financial costs)}

\begin{tabular}{|c|c|c|c|c|c|}
\hline STE O\&M cost breakdown & $\begin{array}{l}\text { STE O\&M } \\
\text { costs } \\
\text { (US\$/MWh } \\
\text { ) }\end{array}$ & $\begin{array}{l}\text { Share } \\
\text { s }\end{array}$ & $\begin{array}{l}\text { NGCC O\&M cost } \\
\text { breakdown }\end{array}$ & $\begin{array}{c}\text { NGCC O\&M } \\
\text { costs } \\
(\mathrm{US} \$ \mathbf{M W h})\end{array}$ & Shares \\
\hline Spare parts and replacement & 1.75 & & $\begin{array}{l}\text { Spare parts and } \\
\text { replacements }\end{array}$ & 0.53 & \\
\hline Solar field & 0.32 & $28 \%$ & $\begin{array}{l}\text { Gas turbine and Heat } \\
\text { Recovery Systems } \\
\text { (GT\&HRS) }\end{array}$ & 0.39 & \\
\hline Receiver & 0.12 & & & & $11 \%$ \\
\hline Thermal energy storage & 0.10 & & $\begin{array}{l}\text { Steam turbine and electrical } \\
\text { equipment (ST\&EQ) }\end{array}$ & 0.14 & \\
\hline Power block & 1.20 & & & & \\
\hline Insurances & 1.26 & $16 \%$ & Insurances & 0.87 & $18 \%$ \\
\hline Water & 0.17 & $3 \%$ & Water consumption & 0.17 & $3 \%$ \\
\hline Regular labor maintenance & 2.19 & $27 \%$ & Regular labor maintenance & 1.69 & $35 \%$ \\
\hline Annual labor maintenance & 2.02 & $26 \%$ & Annual labor maintenance & 1.58 & $33 \%$ \\
\hline Total & 7.39 & $100 \%$ & Total & 4.53 & $100 \%$ \\
\hline
\end{tabular}

Source: Own elaboration based on ESTELA and CFE (2012) cost data, and cost breakdown from Turchi and Heath (2013) and NREL (2008) 
Appendix 4.5. STE and NGCC investment and O\&M demand vectors

\begin{tabular}{|c|c|c|c|c|c|}
\hline \multirow[t]{2}{*}{ Country $^{a}$} & \multirow[t]{2}{*}{ Economic sector } & \multicolumn{2}{|c|}{$\begin{array}{l}\text { Investment cost } \\
(\text { million US\$) }\end{array}$} & \multicolumn{2}{|c|}{$\begin{array}{c}\text { O\&M costs } \\
(1000 U S \$)\end{array}$} \\
\hline & & STE & NGCC & STE & NGCC \\
\hline DEU & Chemicals & 16.9 & - & - & - \\
\hline DEU & Machinery, Nec & 17.6 & 4.1 & - & - \\
\hline DEU & Electrical and Optical Equipment & 11.1 & 3.3 & - & - \\
\hline DEU & Manufacturing, Nec; Recycling & - & - & 385.7 & 37.2 \\
\hline DEU & Wholesale Trade and Commission Trade & - & - & $2,913.6$ & 281.0 \\
\hline DEU & Water Transport & 0.5 & 0.1 & 7.3 & 0.7 \\
\hline DEU & Other Supporting Transport Activities & - & - & 39.8 & - \\
\hline DEU & Post and Telecommunications & - & - & 193.9 & 18.7 \\
\hline DEU & $\begin{array}{l}\text { Renting of M\&Eq and Other Business } \\
\text { Activities }\end{array}$ & - & - & 348.9 & 37.5 \\
\hline MEX & Other Non-Metallic Mineral & 29.5 & 2.8 & - & - \\
\hline MEX & Basic Metals and Fabricated Metal & 75.6 & 7.0 & - & - \\
\hline MEX & Machinery, Nec & 12.0 & 4.4 & - & - \\
\hline MEX & Electrical and Optical Equipment & 19.0 & 8.9 & - & - \\
\hline MEX & Manufacturing, Nec; Recycling & - & - & $1,104.3$ & 233.7 \\
\hline MEX & Electricity, Gas and Water Supply & - & - & $2,156.3$ & $443,194.8$ \\
\hline MEX & Construction & 21.6 & 1.6 & - & - \\
\hline MEX & Wholesale Trade and Commission Trade & - & - & $8,632.0$ & $1,775.7$ \\
\hline MEX & Inland Transport & 2.2 & 0.7 & 162.1 & $3,789.7$ \\
\hline MEX & Other Supporting Transport Activities & - & - & 15.8 & - \\
\hline MEX & Post and Telecommunications & - & - & 558.9 & 118.3 \\
\hline MEX & Financial Intermediation & 47.2 & 22.5 & $206,291.8$ & $41,893.9$ \\
\hline MEX & Real Estate Activities & 18.0 & 12.5 & - & - \\
\hline MEX & $\begin{array}{l}\text { Renting of M\&Eq and Other Business } \\
\text { Activities }\end{array}$ & 49.3 & 17.3 & 860.8 & 236.9 \\
\hline NLD & Machinery, Nec & 7.0 & - & - & - \\
\hline NLD & Manufacturing, Nec; Recycling & - & - & 99.9 & - \\
\hline NLD & Wholesale Trade and Commission Trade & - & - & 756.6 & - \\
\hline NLD & Water transport & 0.1 & - & 2.3 & - \\
\hline NLD & Post and Telecommunications & - & - & 50.2 & - \\
\hline NLD & $\begin{array}{l}\text { Renting of M\&Eq and Other Business } \\
\text { Activities }\end{array}$ & - & - & 96.9 & - \\
\hline USA & Basic Metals and Fabricated Metal & 41.8 & 2.1 & - & - \\
\hline USA & Machinery, Nec & 11.9 & 2.7 & - & - \\
\hline USA & Electrical and Optical Equipment & 53.2 & 3.5 & - & - \\
\hline USA & Manufacturing, Nec; Recycling & - & - & 639.1 & 348.1 \\
\hline USA & Wholesale Trade and Commission Trade & - & - & $4,856.7$ & $2,623.0$ \\
\hline USA & Inland Transport & 0.7 & 0.3 & 9.4 & 5.1 \\
\hline USA & Other Supporting Transport Activities & - & - & 6.4 & - \\
\hline USA & Post and Telecommunications & - & - & 320.7 & 174.7 \\
\hline \multirow[t]{2}{*}{ USA } & $\begin{array}{l}\text { Renting of M\&Eq and Other Business } \\
\text { Activities }\end{array}$ & - & - & 594.3 & 349.8 \\
\hline & TOTAL & 435.2 & 132.3 & $231,103.6$ & 495,118.8 \\
\hline
\end{tabular}

${ }^{\mathrm{a}} \mathrm{DEU}=$ Germany; MEX = Mexico; NLD = The Netherlands; USA = United States of America

Source: Own elaboration based on ESTELA and CFE (2012) cost data, and cost breakdown from Turchi and Heath (2013) NREL (2008) 


\section{Appendix 4.6. Environmental impact categories and characterization factors used}

\begin{tabular}{|c|c|c|c|c|}
\hline $\begin{array}{l}\text { Impact } \\
\text { categories }\end{array}$ & Gases (g) & $\begin{array}{l}\text { Characterization } \\
\text { factors }\end{array}$ & Sources & $\begin{array}{l}\text { Emission Factors for } \\
\text { natural gas direct use }\end{array}$ \\
\hline \multirow{3}{*}{$\begin{array}{l}\text { Climate } \\
\text { change }\left(\mathrm{gCO}_{2}\right. \\
\text { eq) }\end{array}$} & $\mathrm{gCO}_{2}$ & 1 & \multirow{3}{*}{$\begin{array}{l}\text { IPCC } 2013 \text { (IPCC } \\
2013)\end{array}$} & 412 \\
\hline & $\mathrm{gCH}_{4}$ & 28 & & 0.04 \\
\hline & $\mathrm{gN}_{2} \mathrm{O}$ & 265 & & 0.03 \\
\hline \multirow{3}{*}{$\begin{array}{l}\text { Acification } \\
\left(\mathrm{gSO}_{2} \mathbf{e q}\right)\end{array}$} & $\mathrm{gSO}_{\mathrm{X}}$ & 1 & \multirow{7}{*}{$\begin{array}{l}\text { ReCiPe hierarchist } \\
\text { version, midpoint } \\
\text { method (Goedkoop } \\
\text { et al. 2013) }\end{array}$} & 0.003 \\
\hline & $\mathrm{gNO}_{\mathrm{X}}$ & 0.56 & & 1.57 \\
\hline & $\mathrm{gNH}_{3}$ & 2.45 & & 0.021 \\
\hline \multirow{4}{*}{$\begin{array}{l}\text { Formation of } \\
\text { photochemical } \\
\text { oxidants } \\
\text { (gNMVOC eq) }\end{array}$} & gNMVOC & 1 & & 0.04 \\
\hline & $\mathrm{gNO}_{\mathrm{X}}$ & 1 & & \\
\hline & $\mathrm{gCO}$ & 0.0456 & & 0.027 \\
\hline & $\mathrm{gCH}_{4}$ & 0.0101 & & \\
\hline
\end{tabular}

Source: Own elaboration

Appendix 4.7. Assumptions used for the calculation of induced effects by country of origin

\begin{tabular}{lcccc}
\hline Country & Type of electricity & $\begin{array}{c}\text { Wages shares within labor costs } \\
\text { (in percentage) }\end{array}$ & $\begin{array}{c}\text { OECD households saving } \\
\text { rates } \\
\text { (in percentage) }\end{array}$ \\
\hline & STE & NGCC & & \\
MEX & $\mathrm{X}$ & $\mathrm{X}$ & $86 \%$ & $8 \%$ \\
NLD & $\mathrm{X}$ & & $86 \%$ & $15 \%$ \\
DEU & $\mathrm{X}$ & $\mathrm{X}$ & $93 \%$ & $10 \%$ \\
USA & $\mathrm{X}$ & $\mathrm{X}$ & $93 \%$ & $6 \%$ \\
\hline
\end{tabular}

Source: Own elaboration based on WIOD and OECD 


\section{Appendix 4.8. Direct and indirect effects of both technologies by social}

\section{impact category}

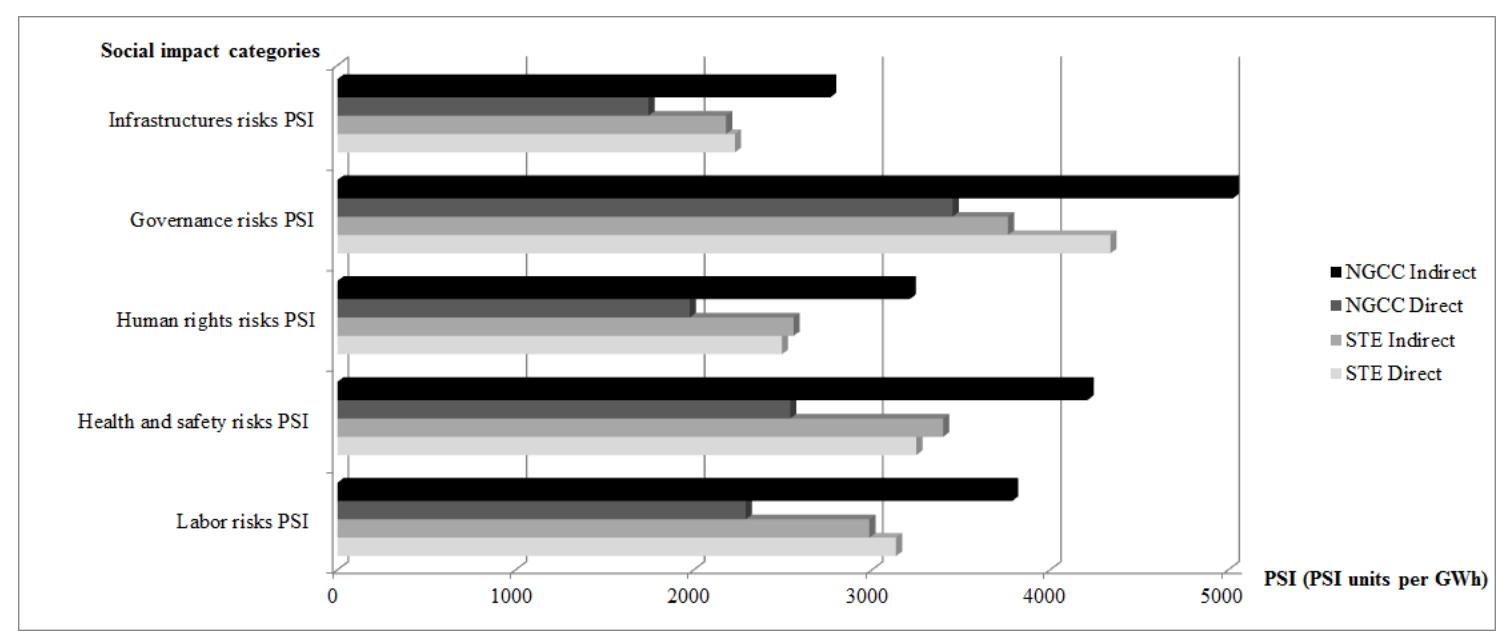

Source: Own elaboration

\section{Appendix 4.9. Contribution of Project Social Hotspots of NGCC and STE}

\begin{tabular}{|c|c|c|}
\hline \multirow[b]{2}{*}{ Economic sectors } & \multicolumn{2}{|c|}{$\begin{array}{c}\text { Contribution of Project Social } \\
\text { Hotspots (in percentage) }\end{array}$} \\
\hline & NGCC & STE \\
\hline Other Non-Metallic Mineral & & $4 \%$ \\
\hline Basic Metals and Fabricated Metal & & $6 \%$ \\
\hline Electricity, Gas and Water Supply & $26 \%$ & \\
\hline Construction & $5 \%$ & $11 \%$ \\
\hline Retail Trade, Except of Motor Vehicles and Motorcycles & $12 \%$ & \\
\hline Financial Intermediation & $5 \%$ & $16 \%$ \\
\hline Renting of $\mathrm{M} \& \mathrm{Eq}$ and Other Business Activities & $13 \%$ & $25 \%$ \\
\hline Total contribution & $60 \%$ & $62 \%$ \\
\hline
\end{tabular}

Source: Own elaboration 


\section{Appendix 4.10. Total environmental results for both technologies and comparison with literature}

\begin{tabular}{|c|c|c|c|c|c|}
\hline $\begin{array}{l}\text { Environmental } \\
\text { impacts }\end{array}$ & $\begin{array}{l}\text { Energy } \\
\text { consumption } \\
(\mathbf{M J} / \mathbf{k W h})\end{array}$ & $\begin{array}{l}\text { Climate Change (g } \\
\mathrm{CO}_{2} \mathrm{eq} / \mathrm{kWh} \text { ) }\end{array}$ & $\begin{array}{l}\text { Acidification (g } \\
\mathrm{SO}_{2} \text { eq/kWh) }\end{array}$ & $\begin{array}{l}\text { Photoch. oxidants } \\
\text { (g NMVOC } \\
\text { eq/kWh) }\end{array}$ & $\begin{array}{l}\text { Percentage of } \\
\text { affection to } \\
\text { threatened species }\end{array}$ \\
\hline STE Total effects & 0.5 & 24 & 0.08 & 0.14 & 0.0017 \\
\hline $\begin{array}{l}\text { STE Comparison } \\
\text { with literature }\end{array}$ & $\begin{array}{l}0.14-0.36 \\
2.79 \text { with } \\
\text { gas abc }\end{array}$ & $12-24 ; 70$ with gas abcd & 0.4 with gas $^{\mathrm{b}}$ & 0.7 with gas $^{\mathrm{b}}$ & - \\
\hline $\begin{array}{l}\text { NGCC Total } \\
\text { effects }\end{array}$ & 11.5 & 603 & 1.6 & 2.2 & 0.0297 \\
\hline $\begin{array}{l}\text { NGCC } \\
\text { Comparison with } \\
\text { literature }\end{array}$ & 7. $8^{\mathrm{g}}-8.4^{\mathrm{h}}$ & $\begin{array}{l}585^{\mathrm{h}}, 468^{\mathrm{i}}, 580^{\mathrm{j}}, 493^{\mathrm{g}} \\
440-780^{\prime} ; 466-655^{\mathrm{k}}\end{array}$ & $0.55^{\mathrm{j}}$ & $0.84^{\mathrm{j}}$ & - \\
\hline
\end{tabular}

\section{Appendix 4.11. Contribution of total effects of STE and NGCC}

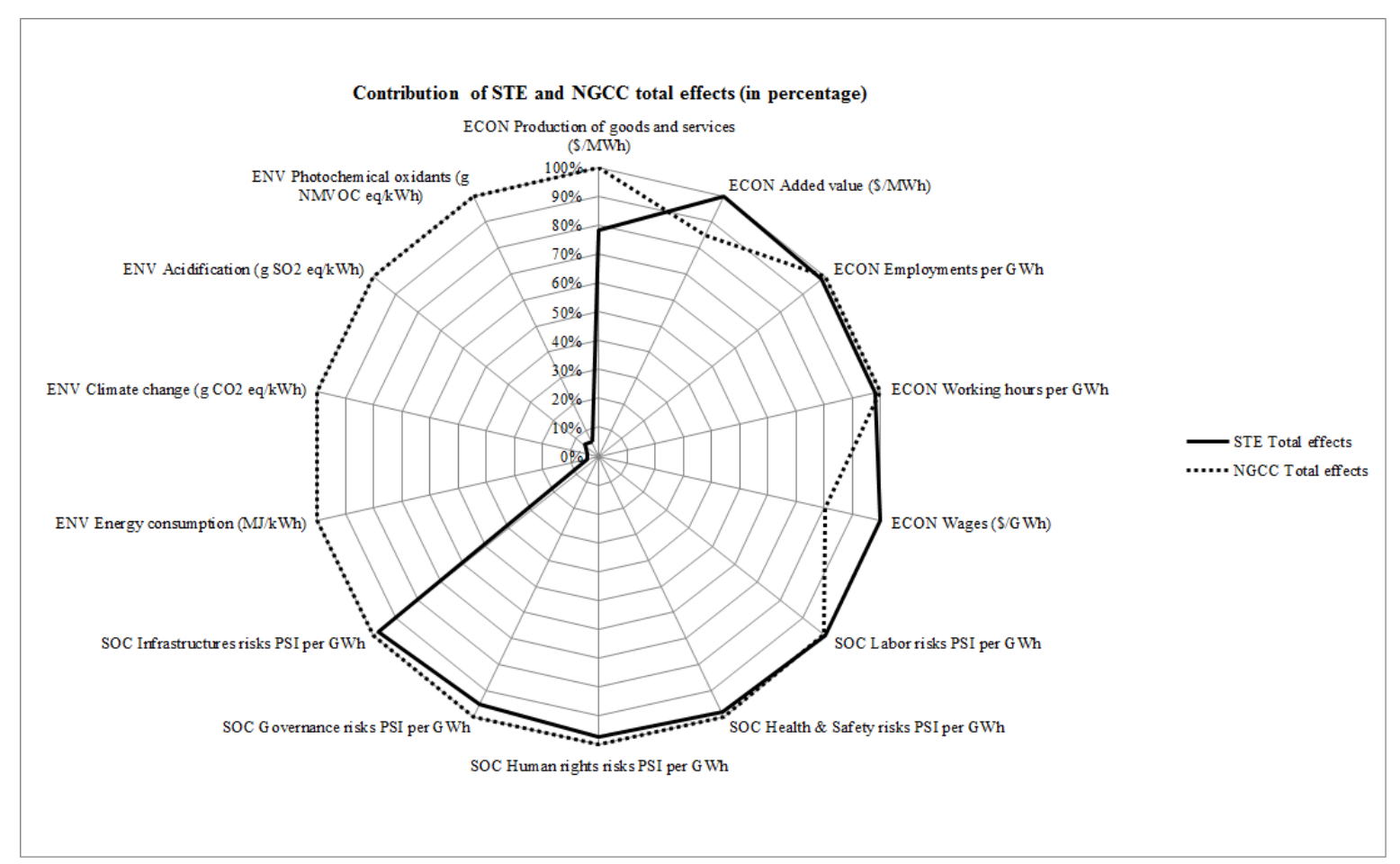

Source: Own elaboration 


\section{Appendix 4.12. Summarized impact comparison of total effects between NGCC and STE (STE reference)}

\begin{tabular}{llc}
\hline Sustainability pillar & Impact assessed & $\begin{array}{c}\text { Differences on effects between NGCC } \\
\text { and STE (in percentage, STE reference) }\end{array}$ \\
\hline \multirow{5}{*}{ ECONOMIC } & Production of goods and services & $-5 \%$ \\
& Added value creation & $+15 \%$ \\
& Employments & $-1 \%$ \\
& Working hours & $-2 \%$ \\
& Wages & $+20 \%$ \\
SOCIAL & Labor rights risks PSI & $+1 \%$ \\
& Health and safety risks PSI & $-2 \%$ \\
& Human rights risks PSI & $-3 \%$ \\
& Governance risks PSI & $-4 \%$ \\
& Community infrastructures risks PSI & $-2 \%$ \\
& & \\
& Energy consumption & $-96 \%$ \\
& Climate change & $-96 \%$ \\
& Acidification & $-95 \%$ \\
& Photochemical oxidants & $-94 \%$ \\
& Affection to threatened species & $-94 \%$ \\
\hline
\end{tabular}

Source: Own elaboration 


\section{Appendix 5.1 Invitation and reminder email for the questionnaire case study}

The questionnaire was sent via email in January 2016, and two reminders were sent in the following two weeks. The original invitation (first one) and reminder email (second one) in Spanish for the questionnaire case study are shown below:
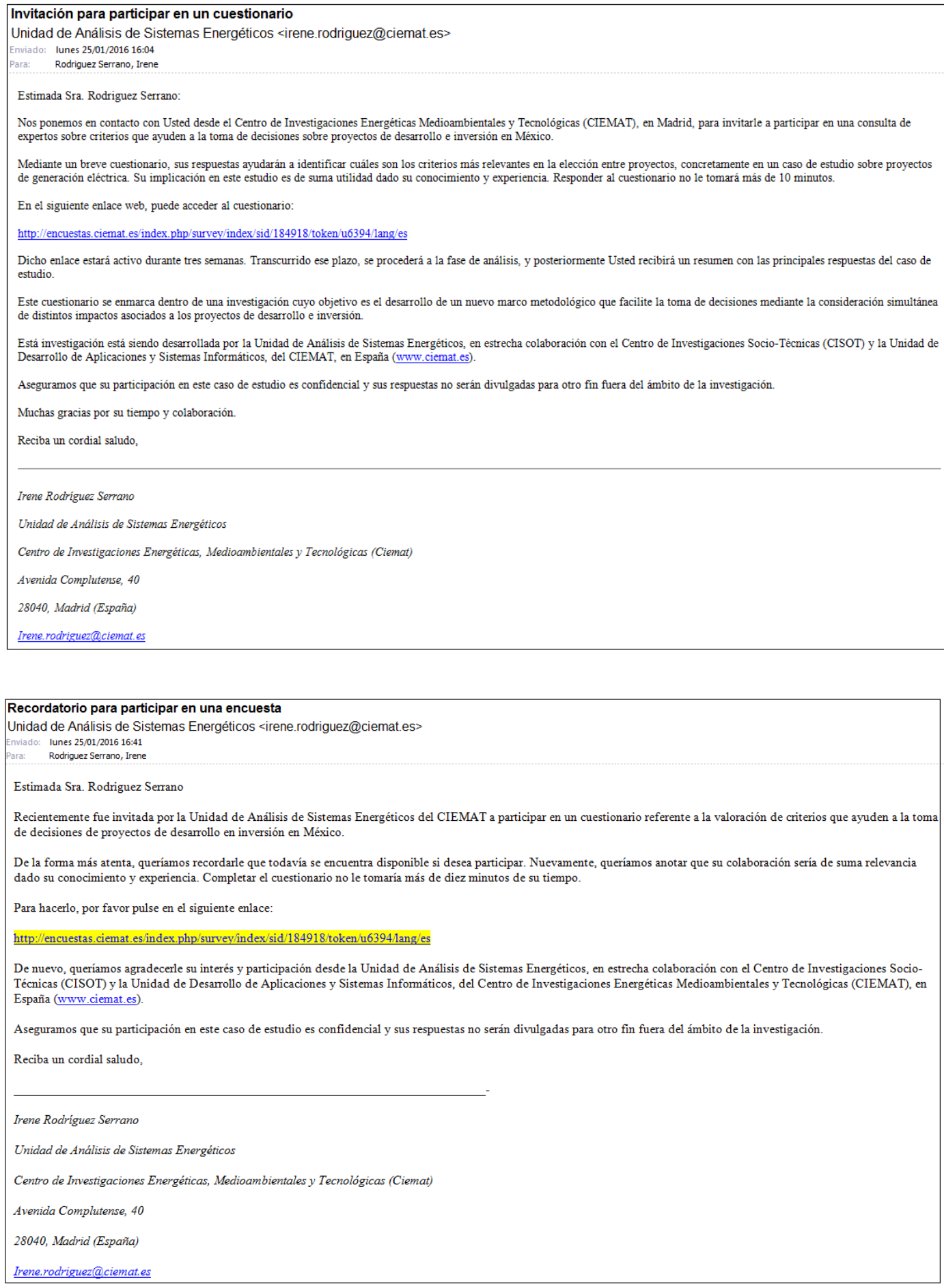


\section{Appendix 5.2. Original questionnaire}

The questionnaire includes six sections. Part 1 includes questions related to decision makers' working and knowledge areas. In Part 2, interviewees have to indicate which criteria they usually take into account in their decision making processes. In Part 3 , the fifteen impacts analyzed within FISA are displayed and interviewees have to score the relevance of these impacts for their decision making processes, in which 0 means no relevance and 5 the maximum relevance. Then, in Part 4 interviewees have to rank only the top 5 impacts more relevant. Part 5 asks for other suggested impacts/indicators that are not included within FISA. Finally, in Part 6 decision makers can explain the reasons of the usefulness of FISA impacts and make any other comments related to the survey. The original online questionnaire is displayed below. 


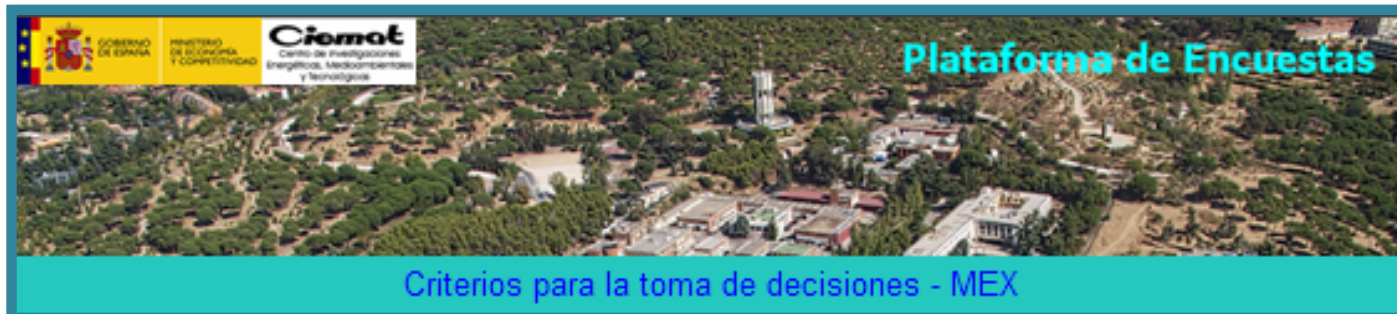

Usted ha sido invitado a participar en este cuestionario sobre la valoración de indicadores que ayuden a la toma de decisiones sobre proyectos en México. Concretamente, el cuestionario hace referencia a un proyecto de generación de electricidad.

El cuestionario tiene una duración aproximada de 10 minutos y está estructurado en seis partes:

1. Perfil personal y laboral.

2. Criterios que usted consideraría relevantes para la toma de decisiones sobre un proyecto energético en México, que será contextualizado en la sección posterior.

3. Preferencias dentro de una lista dada de posibles criterios (indicadores) a considerar como relevantes en la toma de decisiones del proyecto en cuestión.

4. Selección de aquellos cinco indicadores de la lista dada en la parte 3 que consideraría más relevantes.

5. Posibilidad de incluir otros indicadores no mencionados anteriormente que consideraría relevantes en la toma de decisiones relacionadas con el proyecto.

6. Comentarios generales.

Este cuestionario es estrictamente para propósitos de investigación. Aseguramos que su participación en este cuestionario es confidencial y no será divulgada para otro objetivo fuera del alcance de la investigación.

Nota informativa: cada vez que usted seleccione la opción "Siguiente", no podrá regresar a etapas anteriores del cuestionario. Las partes 2,5 y 6 son de respuesta optativa.

Muchas gracias por su participación 


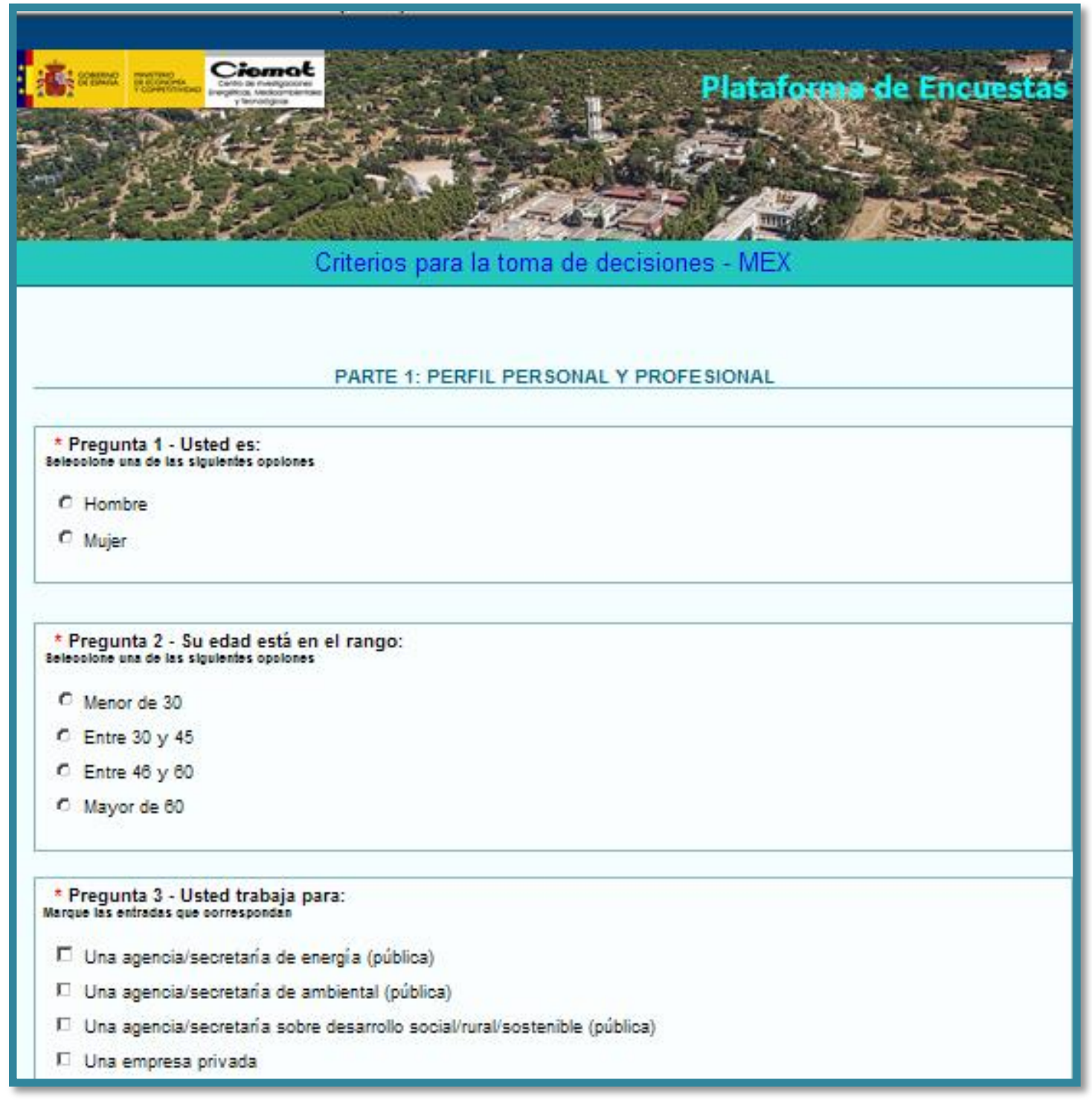


- Pregunta 4 - Usted lleva en su actual agenclalempresa:

aslevolone und de les sloulentes opelones

C Menos de dos atos

C Entre dos y clnoo ahos

C. Entre choo y olez afios

C. Entre dlez y veinte ahos

C. Mas de veinte aflos

- Pregunta 5 - Su princlpal area de conocimlento esta enfocada a aspectos: Marque las entrades que corresponsan
Г Tecoloos
$\square$ Legales
Г Eoonomiloos
I Soclales
Г Poiticos
Г Amblentalesiecologloos
Г Otro:

- Pregunta 6 - Su actual trabajo esta princlpalmente orlentado a: Marque las entrades que corres ponden
Г Desarrollo tecnologloo
I. Aspectos legales
Г Estudios de viablilidad economica
Г Gestion de rlesgos
Г Cuestiones poificas
I Evaluacion de projectosilmpactos
Г Desarrollo soclaunura|
Г Docencla
Г Projectos de investigacion e Innovacion
I otro: 


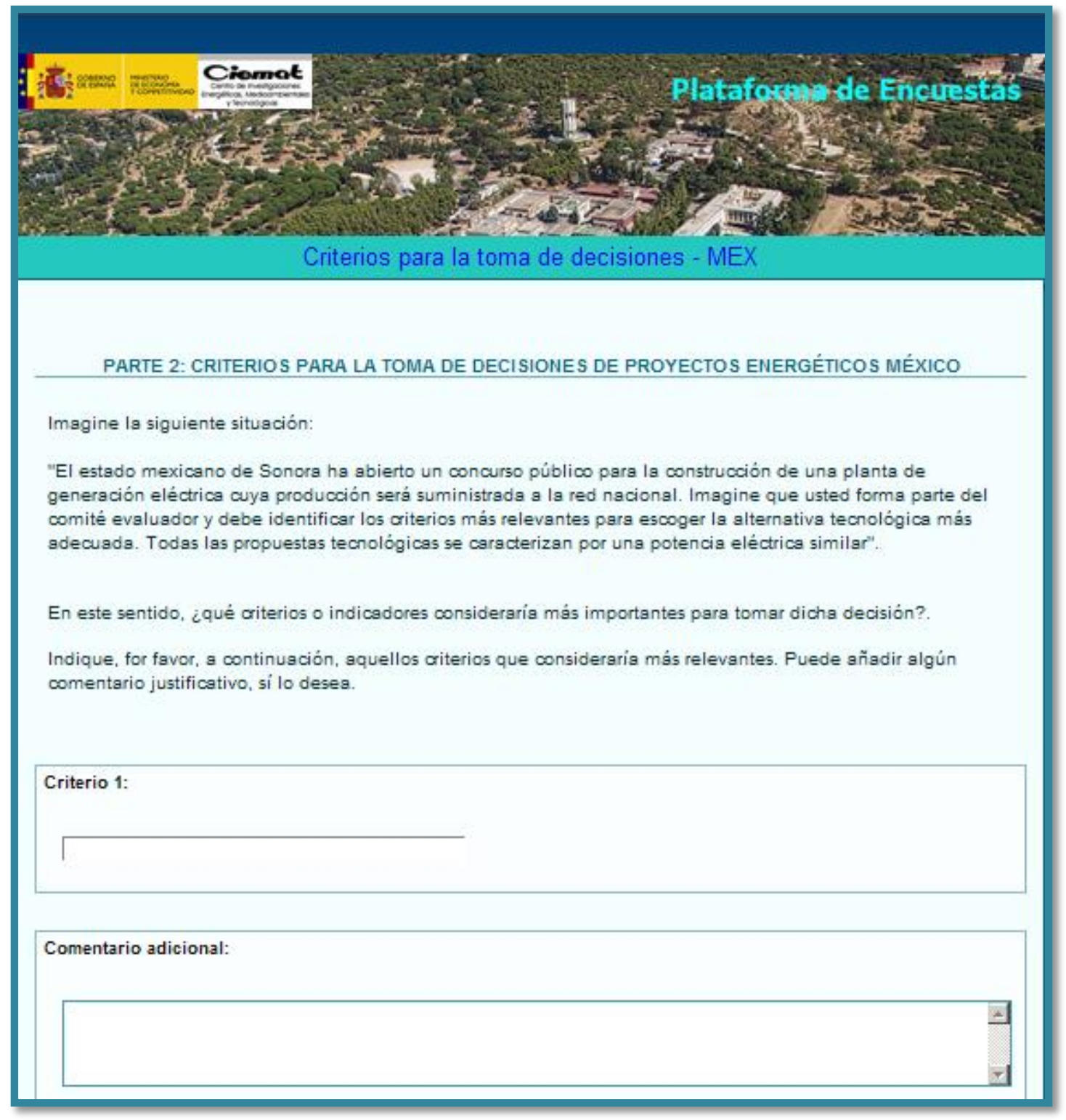


Criterio 2:

「

Comentario adicional:

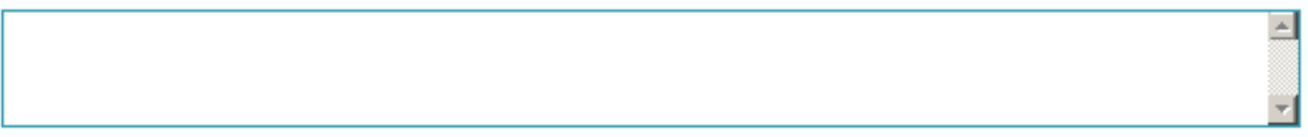

Criterio 3:

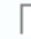

Comentario adicional:

Otros criterios:

Sigulenter

Sallr y borrar la encuesta

Continuar despues 


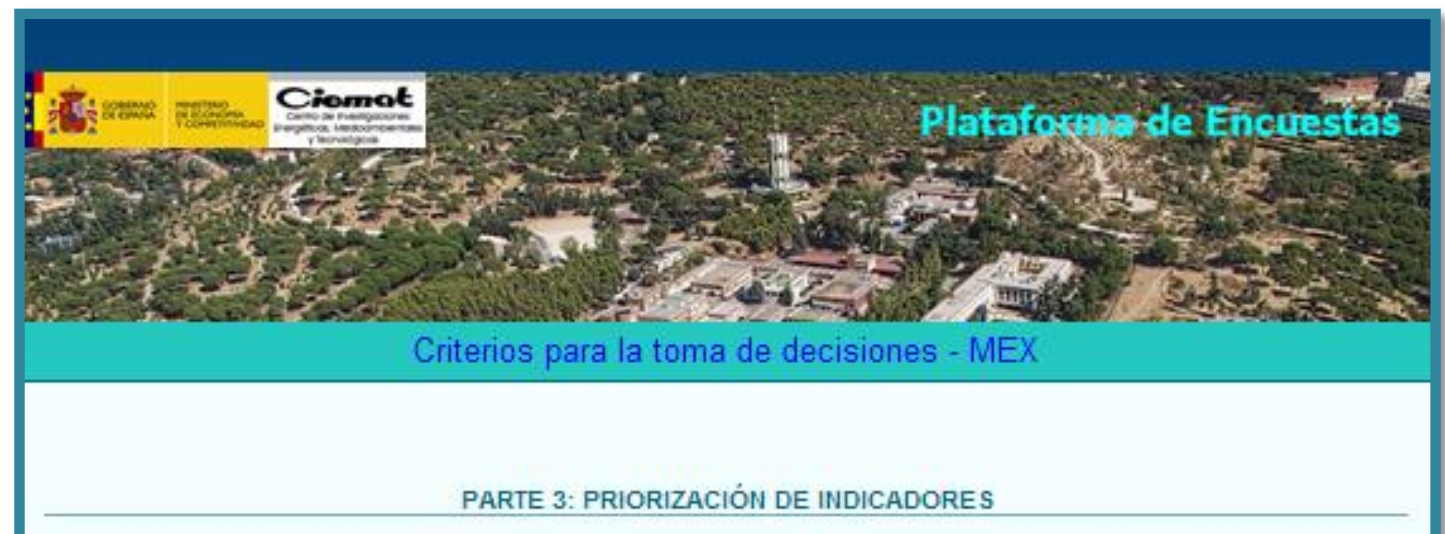

En esta sección, se presenta un listado de quince indicadores (criterios) que podrian ser considerados para la toma de decisiones de proyectos de generación eléctrica, como el del ejemplo expuesto en la sección anterior. Por favor, señale la importancia de cada indicador utilizando una escala de cero a cinco, indicando:

- O no relevante (no consideraría este indicador en la toma de decisiones)

- 1 muy poco relevante

- 2 poco relevante

- 3 relevancia media

- 4 relevancia alts

- 5 muy relevante

A continuación, se induyen unos apuntes que pueden ayudar en la asignación de puntuaciones:

0 puntos: no consideraría ese indicador relevante para la toma de decisiones, no lo tendría en cuenta en ningún proyecto o caso de estudio.

1 punto: consideraría este aspecto muy poco relevante y lo tendría en cuenta en escasas situsciones muy especificas.

2 puntos: consideraría este aspecto poco relevante y lo tendria en cuenta solo en algunas ocasiones.

3 puntos: consideraría este aspecto relevante y lo tendría en cuenta frecuentemente, aunque no de manera prioritaria.

4 puntos: consideraria este aspecto muy relevante y lo tendría en cuenta en la mayoria de las ocasiones, pero tendria en cuenta otros aspectos previamente.

5 puntos: consideraría este aspecto como prioritario por su gran relevancia y lo tendria en cuenta en todos los procesos de toma de decisiones. 
Para mas Informacion sobre los indlcadores, pinche aqui

\begin{tabular}{|c|c|c|c|c|c|c|}
\hline & & & Puntuaciones & & & \\
\hline & 0 & 1 & 2 & 3 & 4 & 5 \\
\hline $\begin{array}{r}1 \text { Generación de } \\
\text { empleo }\end{array}$ & $c$ & $\boldsymbol{r}$ & $\sigma$ & c & $c$ & c \\
\hline 2 Consumo de agua & $c$ & $r$ & $r$ & $r$ & c & $c$ \\
\hline $\begin{array}{l}3 \text { Generación de } \\
\text { contaminantes locales }\end{array}$ & $c$ & $r$ & c & $\boldsymbol{c}$ & r & c \\
\hline $\begin{array}{r}4 \text { Generacion de } \\
\text { salarios }\end{array}$ & $c$ & $r$ & $r$ & $r$ & $c$ & c \\
\hline $\begin{array}{r}5 \text { Risegos de } \\
\text { vulneracion de } \\
\text { derechos humanos }\end{array}$ & $c$ & $c$ & $c$ & $c$ & $c$ & c \\
\hline $\begin{array}{l}6 \text { Emisiones de Gases } \\
\text { de Efecto Invernadero }\end{array}$ & $c$ & $r$ & c & $r$ & c & c \\
\hline $\begin{array}{r}7 \text { Riesgos de } \\
\text { vulneracion de } \\
\text { derechos laborales }\end{array}$ & $c$ & $r$ & c & $c$ & c & c \\
\hline $\begin{array}{r}\text { B Estimulación } \\
\text { económies generads }\end{array}$ & $c$ & $c$ & $c$ & $c$ & $c$ & c \\
\hline $\begin{array}{r}9 \text { Riesgos de } \\
\text { deficiencis en } \\
\text { infraestructuras } \\
\text { comunitarias }\end{array}$ & $c$ & c & $\boldsymbol{c}$ & C & c & c \\
\hline $\begin{array}{r}10 \text { Reduceión de } \\
\text { biodiversidad }\end{array}$ & $c$ & $r$ & $\boldsymbol{c}$ & $c$ & $r$ & $c$ \\
\hline 1 Costes del proyecto & $c$ & c & c & $\boldsymbol{r}$ & c & $c$ \\
\hline $\begin{array}{r}12 \text { Riesgos } d e \\
\text { incumplimiento de } \\
\text { segurided y salud } \\
\text { laboral }\end{array}$ & $c$ & $c$ & $c$ & $c$ & $c$ & $c$ \\
\hline $\begin{array}{r}13 \text { Consumo de } \\
\text { energís }\end{array}$ & $c$ & $r$ & $\sigma$ & $r$ & $c$ & $c$ \\
\hline $\begin{array}{l}14 \text { Riesgos an los } \\
\text { sistemas legales } \\
\text { gubernamentales }\end{array}$ & $c$ & $r$ & $r$ & $r$ & $r$ & $c$ \\
\hline $\begin{array}{l}15 \text { Duración de la } \\
\text { jornads laboral }\end{array}$ & $c$ & $c$ & $c$ & $c$ & $c$ & $c$ \\
\hline
\end{tabular}

Slgulenter

Soll y borrer la encuesta

Continuser desputs 
PARTE 4: SELECCIÓN DE 5 INDICADORES

Si de los quince indicadores presentados en la sección anterior tuviese que elegir los cinco más relevantes a tener en cuenta para la toma de una decisiones en proyectos de generación eléctrica comentados anteriormente, ¿cuáles elegiría y por qué?

Por favor indique en la primera posición el indicador que seleccionaria en primer lugar, hasta el último en importancia en la quinta posición.

Indicador:

Clasificación (máx. 5):

\begin{tabular}{||l||}
\hline 1 Generación de empleo \\
\hline 2 Consumo de agua \\
\hline 3 Generación de contaminantes locales \\
\hline 4 Generación de salarios \\
\hline 5 Riesgos de vulneración de derechos humanos \\
\hline 6 Emisiones de Gases de Efecto Invernadero \\
\hline 7 Riesgos de vulneración de derechos laborales \\
\hline 8 Estimulación económica generada \\
\hline 9 Riesgos de deficiencia en infraestructuras \\
\hline 10 Reducción de biodiversidad \\
\hline 11 Costes del proyecto \\
\hline 12 Riesgos de incumplimiento de seguridad y salud \\
\hline 13 Consumo de energia \\
\hline 14 Riesgos en los sistemas legales gubernamentales \\
\hline 15 Duración de la jornada laboral \\
\hline
\end{tabular}




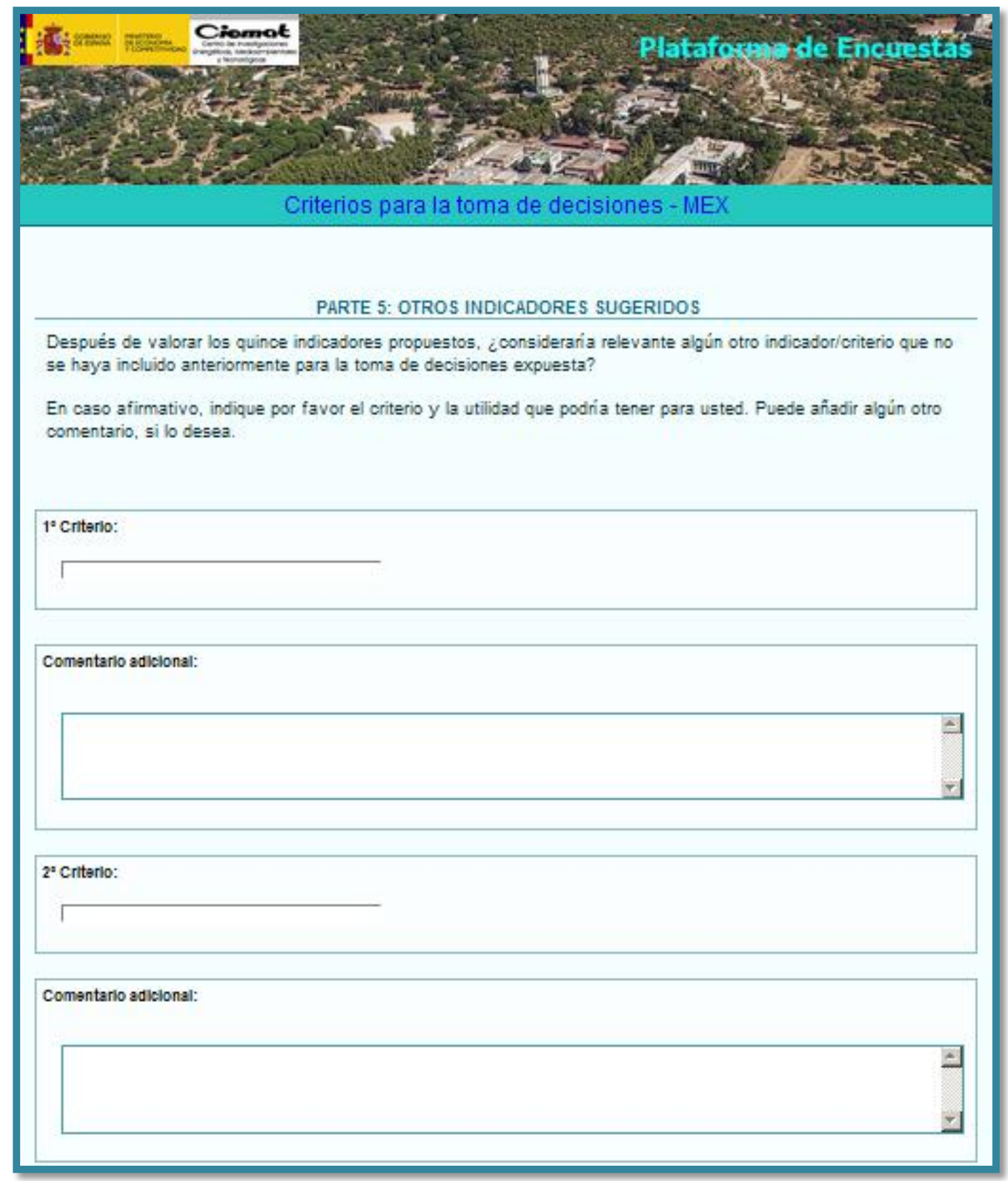




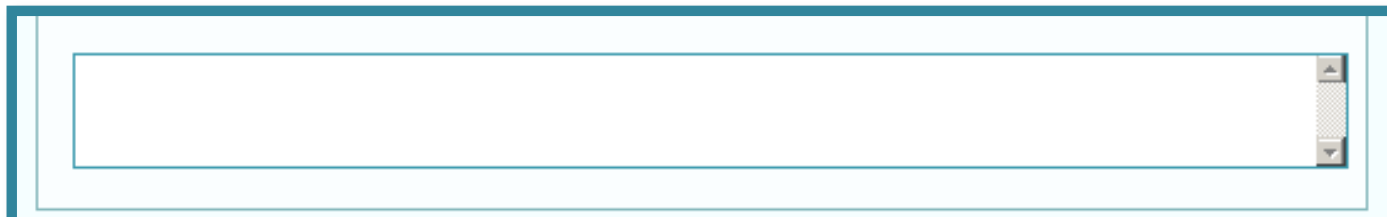

$3^{\circ}$ Criterio:

Comentario adicional:

Otros criterios: 


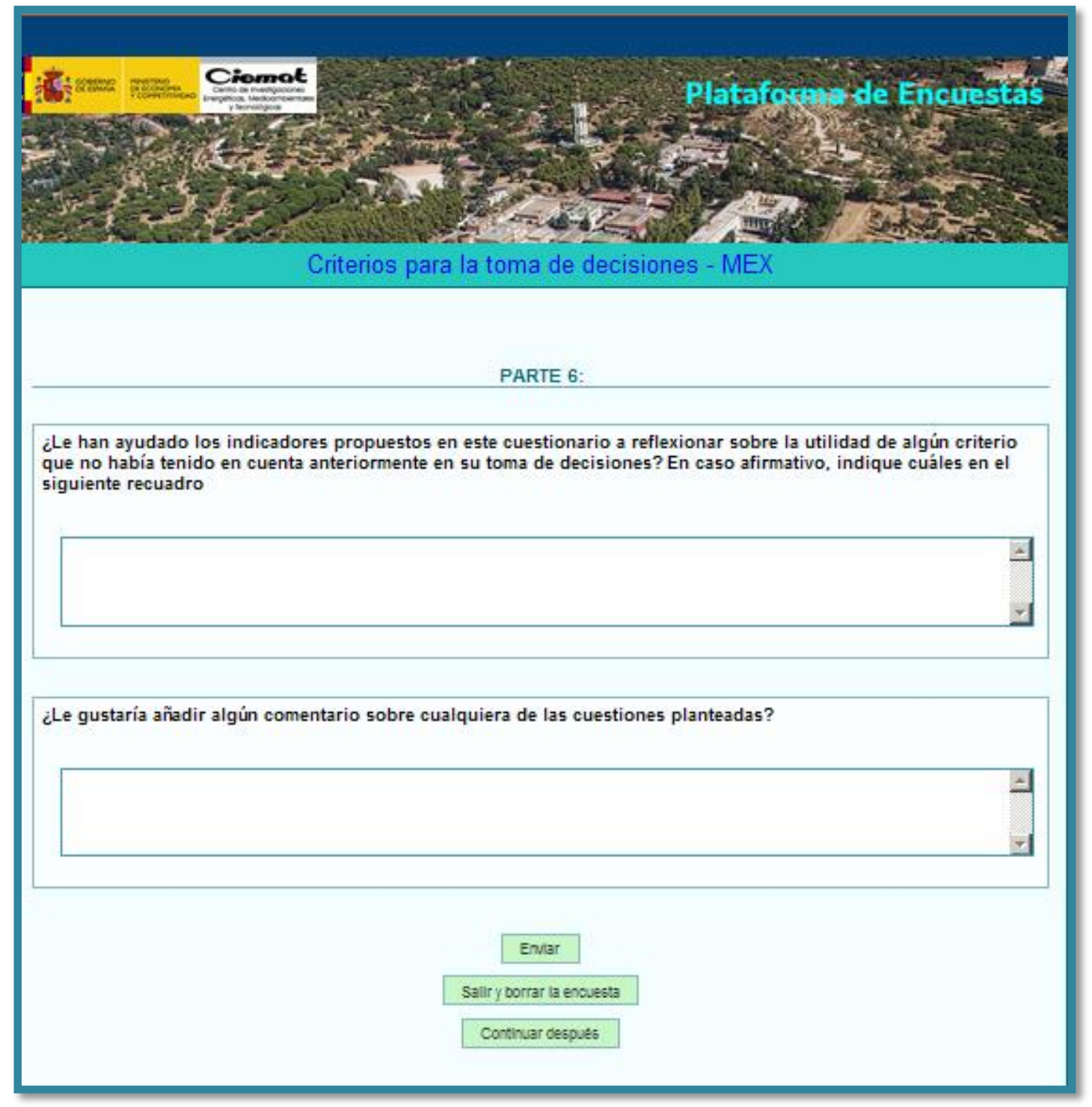


Appendix 5.3. Original description of suggested indicators (Linked online to Part 3 of the questionnaire)

\section{Descripción de indicadores}

El objetivo de esta sección es facilitar el cumplimiento del cuestionario mediante la provisión de una definición de los 15 indicadores incluidos en la misma.

1. Generación de empleo: Son los empleos que se van a generar a partir del proyecto, tanto de forma directa (por ejemplo durante la construcción o empleos fijos de mantenimiento) como indirecta (por ejemplo sector hostelero que da servicios a los trabajadores de la planta).

2. Consumo de agua: Es el consumo de agua total que conlleva el proyecto.

3. Generación de contaminantes locales: Son las emisiones de contaminantes locales (partículas en suspensión, NOx,..) asociadas a todas las actividades involucradas en el proyecto.

4. Generación de salarios: Se refiere a los salarios generados de todos los empleos que genera el proyecto.

5. Riesgos de vulneración de derechos humanos: Se refiere a la existencia de posibles riesgos relacionados con vulneración de los derechos humanos (por ejemplo: derechos de las poblaciones indígenas, desigualdad de género, etc.) presentes en los sectores económicos relacionados con el proyecto.

6. Emisiones de Gases de Efecto Invernadero: Son las emisiones totales de Gases de Efecto Invernadero (principalmente $\mathrm{CO}_{2}, \mathrm{CH}_{4}$ y $\mathrm{N}_{2} \mathrm{O}$ ) asociadas a las actividades involucradas en el proyecto.

7. Riesgos de vulneración de derechos laborales: Se refiere al posible riesgo de incumplimiento de una serie de derechos laborales (trabajo infantil, trabajos forzosos, etc.) presentes en los sectores económicos relacionados con el proyecto. 
8. Estimulación económica generada: Se refiere a toda la estimulación económica que se generaría del proyecto, desde actividades directas como construcción e instalación del proyecto, hasta otras más indirectas como servicios de marketing, publicidad, investigación, etc.

9. Riesgos de deficiencias en infraestructuras comunitarias: Se refiere a la existencia de posibles riesgos relacionados con falta 0 deficiencia en infraestructuras y servicios básicos (provisión de agua potable, letrinas, sistemas de salud, etc.) en las comunidades asociadas directa o indirectamente con el proyecto.

10. Reducción de la biodiversidad: Se refiere a la cantidad de especies que pueden verse mermadas por todas las actividades que conlleve el proyecto.

11. Costes del proyecto: Se refieren a los costes de inversión y operación y mantenimiento del proyecto.

12. Riesgos de incumplimiento de seguridad y salud laboral: Se refiere a la existencia de posibles riesgos para la salud de los trabajadores (por ejemplo: niveles muy elevados de ruido, gases contaminantes, accidentes laborales, etc.) presentes en los sectores económicos relacionados con el proyecto.

13. Consumo de energía: Es el consumo energético total asociado a todas las actividades que conlleve el proyecto.

14. Riesgos en los sistemas legales gubernamentales: Se refiere a diferentes riesgos relacionados con el sistema legal de los gobiernos, como claridad de las leyes, acceso a la justifica, eficiencia en los procesos judiciales o transparencia del gobierno.

15. Duración de la jornada laboral: Son las horas de trabajo semanales desempeñadas en los empleos generados por el proyecto. 


\section{Appendix 5.4. Interviewees' detailed answers to optional questions of the survey}

This part includes detailed answers to the optional questions within parts 2, 5 and 6 of the questionnaire

\section{Appendix 5.3.1. Parte 2 del cuestionario}

Pregunta: ¿Qué criterios o indicadores consideraría más importantes en su toma de decisiones?

\begin{tabular}{|c|c|c|c|c|c|c|}
\hline $\begin{array}{l}\text { ENCUES- } \\
\text { TADO No }\end{array}$ & $\begin{array}{c}\text { CRITERIO } \\
\text { 1: }\end{array}$ & $\begin{array}{l}\text { COMENTARIO } \\
\text { ADICIONAL: }\end{array}$ & $\begin{array}{c}\text { CRITERIO } \\
\text { 2: }\end{array}$ & COMENTARIO ADICIONAL: & $\begin{array}{c}\text { CRITERIO } \\
\text { 3: }\end{array}$ & $\begin{array}{l}\text { COMENTARIO } \\
\text { ADICIONAL: }\end{array}$ \\
\hline (1) & $\begin{array}{l}\text { Fuente de } \\
\text { energía y su } \\
\text { impacto al } \\
\text { medio } \\
\text { ambiente. }\end{array}$ & $\begin{array}{l}\text { Si todas las propuestas } \\
\text { tienen la misma potencia } \\
\text { eléctrica, entonces el } \\
\text { impacto al medio } \\
\text { ambiente debería ser un } \\
\text { factor muy relevante por } \\
\text { los acuerdos en materia de } \\
\text { transición energética. }\end{array}$ & $\begin{array}{l}\text { Costo de } \\
\text { generación } \\
\text { bruta }\end{array}$ & $\begin{array}{l}\text { Para que sea rentable, la planta } \\
\text { debería ser lo más barata posible } \\
\text { en su construcción, operación y } \\
\text { mantenimiento. }\end{array}$ & $\begin{array}{l}\text { Flexibilidad } \\
\text { para } \\
\text { respuesta a la } \\
\text { demanda }\end{array}$ & $\begin{array}{l}\text { Para que ofrezca } \\
\text { beneficios adicionales, } \\
\text { apoyar al proceso de } \\
\text { gestión para } \\
\text { respuesta a la } \\
\text { demanda es una } \\
\text { medida muy } \\
\text { importante para lograr } \\
\text { una red altamente } \\
\text { flexible. }\end{array}$ \\
\hline (2) & \multicolumn{2}{|c|}{ Dotación de recurso para generar } & \multicolumn{2}{|c|}{ Si la tecnología es nacional } & \multicolumn{2}{|c|}{ Mayor empleo generado } \\
\hline
\end{tabular}




\begin{tabular}{|c|c|c|c|c|c|c|}
\hline & \multicolumn{2}{|l|}{ electricidad } & & & & \\
\hline (3) & \multicolumn{2}{|c|}{ Viabilidad técnica y financiera } & \multicolumn{2}{|c|}{ Viabilidad social y ambiental } & \multicolumn{2}{|c|}{ Viabilidad política } \\
\hline (4) & \multicolumn{2}{|c|}{ Impacto global } & \multicolumn{2}{|c|}{ Menor contaminante } & & \\
\hline (5) & $\begin{array}{l}\text { El proyecto } \\
\text { debe ser } \\
\text { económica } \\
\text { mente } \\
\text { atractivo } \\
\text { dentro del } \\
\text { marco } \\
\text { jurídico } \\
\text { (bancable) }\end{array}$ & $\begin{array}{l}\text { En dicho marco, se } \\
\text { prefieren las fuentes } \\
\text { limpias, cuyo impacto } \\
\text { ecológico y social sea } \\
\text { positivo, como indica la } \\
\text { Ley de Transición } \\
\text { Energética. }\end{array}$ & $\begin{array}{l}\text { El tiempo de } \\
\text { recuperació } \\
\text { n de la } \\
\text { inversión } \\
\text { debe ser } \\
\text { menor al de } \\
\text { una nuclear }\end{array}$ & $\begin{array}{l}\text { La nuclear es de gran atractivo } \\
\text { ecológico y político, así que se } \\
\text { puede legítimamente competir con } \\
\text { esta forma energética sobre bases } \\
\text { financieras. }\end{array}$ & $\begin{array}{l}\text { La sociedad } \\
\text { circundante } \\
\text { debe obtener } \\
\text { algún } \\
\text { beneficio } \\
\text { tangible }\end{array}$ & $\begin{array}{l}\text { La tradición } \\
\text { mexicana se ha } \\
\text { percibido como } \\
\text { indiferente o adversa } \\
\text { a las predilecciones de } \\
\text { las poblaciones } \\
\text { locales. Ya es muy } \\
\text { difícil mantener esta } \\
\text { indiferencia, como } \\
\text { ilustran las eólicas del } \\
\text { sur del país. En el } \\
\text { futuro habrá de } \\
\text { corregirse esta } \\
\text { deficiencia social. }\end{array}$ \\
\hline (6) & $\begin{array}{l}\text { Ubicación } \\
\text { geográfica } \\
\text { en Sonora }\end{array}$ & $\begin{array}{l}\text { Cerca de centro } \\
\text { industrial / manufactura }\end{array}$ & $\begin{array}{l}\text { Distancia al } \\
\text { centro de } \\
\text { consumo }\end{array}$ & $\begin{array}{l}\text { Minimizar distancia de } \\
\text { transmisión por cable }\end{array}$ & Agua & $\begin{array}{l}\text { Desaladora } \\
\text { preferiblemente }\end{array}$ \\
\hline (7) & Impacto am & iental de la construcción y & Impacto & Evaluar el impacto social que se & Ciclo de vida & le la tecnología a utilizar \\
\hline
\end{tabular}




\begin{tabular}{|c|c|c|c|c|c|c|}
\hline & \multicolumn{2}{|c|}{ operación de la planta } & social & $\begin{array}{l}\text { tiene en la región, revisar } \\
\text { cuestiones de tenencia de la tierra, } \\
\text { uso de la tierra, comunidades } \\
\text { cercanas, posible población } \\
\text { beneficiada o afectada. }\end{array}$ & & \\
\hline (9) & \multicolumn{2}{|c|}{ Impacto ambiental } & \multicolumn{2}{|c|}{ Eficiencia y productividad } & \multicolumn{2}{|c|}{ Responsabilidad y compromiso social } \\
\hline$(10)$ & \multicolumn{2}{|c|}{ Impacto ambiental } & \multicolumn{2}{|c|}{$\begin{array}{l}\text { Tecnología que se empleará para la generación de } \\
\text { la energía }\end{array}$} & & \\
\hline (11) & \multicolumn{2}{|l|}{ Costos } & \multicolumn{2}{|l|}{ Barreras } & \multicolumn{2}{|l|}{ Impacto } \\
\hline (12) & \multicolumn{2}{|c|}{ Costo beneficio } & \multicolumn{2}{|c|}{ Impacto social y ambiental } & \multicolumn{2}{|c|}{$\begin{array}{l}\text { Contribución a logro de metas y } \\
\text { políticas nacionales }\end{array}$} \\
\hline (13) & Ambiental & $\begin{array}{l}\text { Con base a que tecnología } \\
\text { emite menos gases de } \\
\text { efecto invernadero }\end{array}$ & Tecnológico & $\begin{array}{l}\text { Con base a que tecnología requiere } \\
\text { menos mantenimiento }\end{array}$ & Económico & $\begin{array}{l}\text { Con base en costos de } \\
\text { tecnología } \\
\text { (construcción, } \\
\text { operación, } \\
\text { desmantelamiento) }\end{array}$ \\
\hline
\end{tabular}




\section{Appendix 5.3.2. Parte 5 del cuestionario}

Pregunta: Después de valorar los quince indicadores propuestos, ¿consideraría relevante algún otro indicador/criterio que no haya incluido anteriormente para la toma de decisiones expuesta?

\begin{tabular}{|c|c|c|c|c|c|c|c|}
\hline $\begin{array}{l}\text { ENCUES- } \\
\text { TADO No }\end{array}$ & $1^{\circ}$ CRITERIO: & $\begin{array}{l}\text { COMENTARIO } \\
\text { ADICIONAL: }\end{array}$ & $2^{\circ}$ CRITERIO: & $\begin{array}{l}\text { COMENTARIO } \\
\text { ADICIONAL: }\end{array}$ & $\begin{array}{c}3^{\circ} \\
\text { CRITERIO: }\end{array}$ & $\begin{array}{l}\text { COMENTARIO } \\
\text { ADICIONAL: }\end{array}$ & $\begin{array}{c}\text { OTROS } \\
\text { CRITERIOS: }\end{array}$ \\
\hline (1) & $\begin{array}{ll}\text { Reglas } & \text { del } \\
\text { Mercado } & \\
\text { Eléctrico } & \\
\text { Mayorista } & \text { en } \\
\text { México } & \end{array}$ & 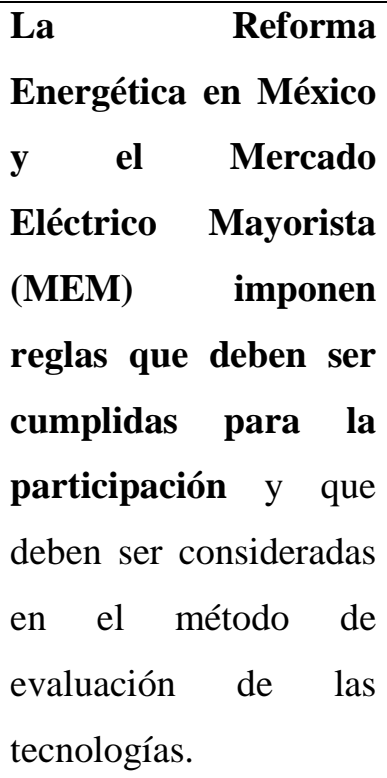 & $\begin{array}{l}\text { Códigos de } \\
\text { red para la } \\
\text { interconexión }\end{array}$ & $\begin{array}{l}\text { Reglas } \\
\text { definidas para } \\
\text { poder hacer la } \\
\text { interconexión } \\
\text { de la generación } \\
\text { el Sistema } \\
\text { Eléctrico } \\
\text { Nacional. }\end{array}$ & $\begin{array}{l}\text { Intermitenci } \\
\text { a de la } \\
\text { generación }\end{array}$ & $\begin{array}{lr}\text { Se deberá } \\
\text { considerar } \\
\text { estabilidad } \\
\text { recurso del } \\
\text { energético de } \\
\text { entrada para } \\
\text { lograr } \\
\text { generación } \\
\text { estable } \\
\text { uniforme. }\end{array}$ & $\begin{array}{l}\text { Aporte a la } \\
\text { flexibilidad } \\
\text { de la red en } \\
\text { general. }\end{array}$ \\
\hline (6) & $\begin{array}{l}\text { Considerar la } \\
\text { bondad de co- }\end{array}$ & $\begin{array}{l}\text { Arriba de tres megas } \\
\text { es rentable co-generar }\end{array}$ & $\begin{array}{l}\text { Minimizar } \\
\text { por lo tanto el }\end{array}$ & $\begin{array}{l}\text { Los errores en } \\
\text { dimensionamie }\end{array}$ & $\begin{array}{l}\text { Proyectar } \\
\text { con ética } \mathbf{y}\end{array}$ & $\begin{array}{l}\text { Que el proyecto } \\
\text { incluya } \quad \text { el }\end{array}$ & $\begin{array}{l}\text { Selección de } \\
\text { equipos con }\end{array}$ \\
\hline
\end{tabular}




\begin{tabular}{|c|c|c|c|c|c|c|c|}
\hline & $\begin{array}{l}\text { generar en la } \\
\text { zona }\end{array}$ & $\begin{array}{l}\text { hasta un } 20 \% \text { del } \\
\text { consumo }\end{array}$ & $\begin{array}{l}\text { tamaño } \\
\text { capacidad de } \\
\text { la planta }\end{array}$ & $\begin{array}{lr}\text { nto } & \text { son } \\
\text { producto de } & \text { no } \\
\text { considerar } & \\
\text { todos } & \text { los } \\
\text { factores } & \\
\text { externos y } & \text { las } \\
\text { variables no } \\
\text { controlables. }\end{array}$ & $\begin{array}{l}\text { seguridad } \\
\text { sostenibles }\end{array}$ & $\begin{array}{l}\text { programa- } \\
\text { calendario de } \\
\text { mantenimiento } \\
\text { preventivo }\end{array}$ & 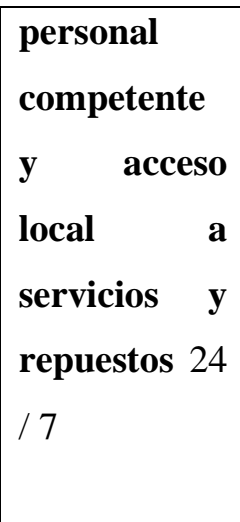 \\
\hline
\end{tabular}




\section{Appendix 5.3.3. Parte 6 del cuestionario}

Pregunta: ¿Le han ayudado los indicadores propuestos en este cuestionario a reflexionar sobre la utilidad de algún criterio que no había tenido en cuenta anteriormente en su toma de decisiones? en caso afirmativo, indique cuáles

\begin{tabular}{|c|l|l|}
\hline $\begin{array}{l}\text { ENCUE } \\
\text { STADO } \\
\mathbf{N}^{\mathbf{o}}\end{array}$ & $\begin{array}{l}\text { iLE HAN AYUDADO LOS INDICADORES } \\
\text { PROPUESTOS? }\end{array}$ & $\begin{array}{l}\text { iLE GUSTARÍA AÑADIR ALGÚN COMENTARIO ADICIONAL } \\
\text { SOBRE CUALQUIERA DE LAS PREGUNTAS ANTERIORMENTE } \\
\text { PLANTEADAS? }\end{array}$ \\
\hline$(1)$ & $\begin{array}{l}\text { Generación de empleo, riesgos de trabajo, uso de agua, } \\
\text { violación de los derechos humanos. }\end{array}$ & $\begin{array}{l}\text { La encuesta me ha hecho reflexionar en el tema, la disfruté y agradezco } \\
\text { haber participado. }\end{array}$ \\
\hline$(4)$ & $\begin{array}{l}\text { Sí. Ya que todos los proyectos deben de ser analizados profundamente tomando en cuenta aspectos mencionados en las partes } \\
\text { anteriores, ya que son importantes debido a que se debe de tener conocimiento de las posibles consecuencias que podría ocasionar un } \\
\text { nuevo proyecto no solo en la sociedad, si no en el ecosistema. }\end{array}$ \\
\hline$(6)$ & $\begin{array}{l}\text { Considerar sueldos que eliminen posibilidad de } \\
\text { corrupción. Contratar técnicos e ingenieros de }\end{array}$ & $\begin{array}{l}\text { Analizar y subsanar las posibles implicaciones políticas entre los múltiples } \\
\text { actores tanto instituciones como proveedores. Respetar el \% de } \\
\text { integración nacional. }\end{array}$ \\
\hline$(9)$ & Universidad local \\
\hline$(10)$ & So lo del consumo del agua y los derechos laborables \\
\hline$(11)$ & Si, la verdad es que todos \\
\hline$(12)$ & No \\
\hline$(13)$ & Vulnerabilidad laboral \\
\hline
\end{tabular}


